WCH-428

Rev. 0

River Corridor Closure Contract

2010 River Corridor Closure Contractor Revegetation and Mitigation Monitoring Report

\title{
September 2010
}

For Public Release

Washington Closure Hanford

Prepared for the U.S. Department of Energy, Richland Operations Office Office of Assistant Manager for River Corridor 
TRADEMARK DISCLAIMER

Reference herein to any specific commercial product, process, or service by trade name, trademark, manufacturer, or otherwise, does not necessarily constitute or imply its endorsement, recommendation, or favoring by the United States Government or any agency thereof or its contractors or subcontractors.

This report has been reproduced from the best available copy.

Printed in the United States of America 


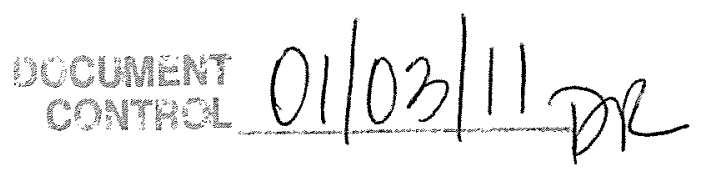

WCH-428

Rev. 0

STANDARD APPROVAL PAGE

Title: 2010 River Corridor Closure Contractor Revegetation and Mitigation Monitoring Report

Author Name: C. T. Lindsey

A. L. Johnson

Approval: $\quad$ J. E. Fletcher Environmental Services Manager
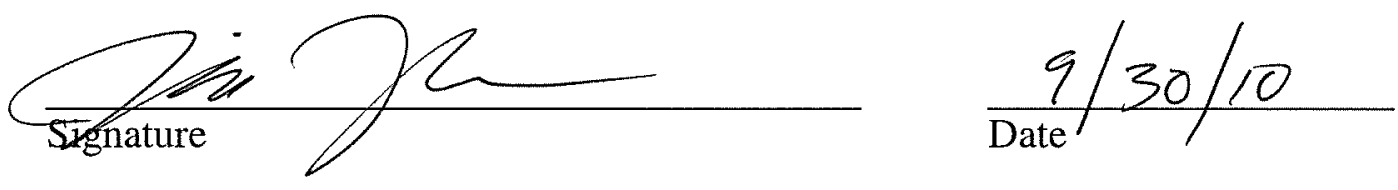

The approval signature on this page indicates that this document has been authorized for information release to the public through appropriate channels. No other forms or signatures are required to document this information release. 

WCH-428

Rev. 0

\section{River Corridor Closure Contract}

\section{River Corridor Closure Contractor Revegetation and Mitigation Monitoring Report}

September 2010

Authors:

C. T. Lindsey

A. L. Johnson

For Public Release 



\section{TABLE OF CONTENTS}

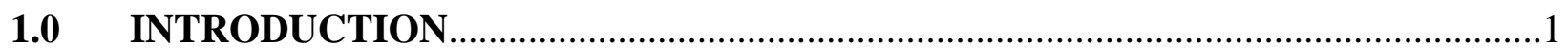

1.1 METHODS USED TO EVALUATE VEGETATION RECOVERY .....................1

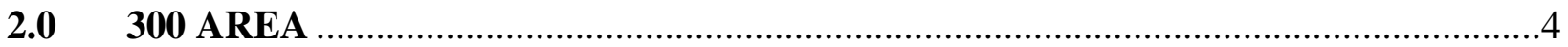

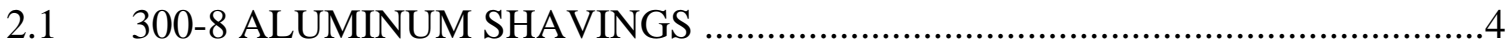

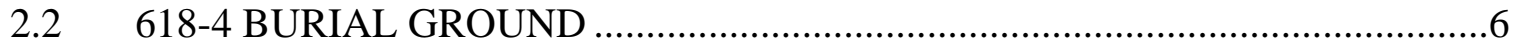

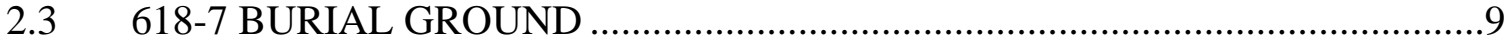

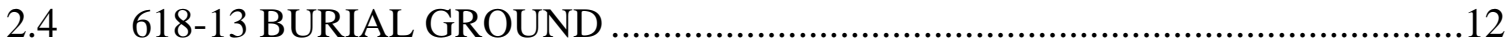

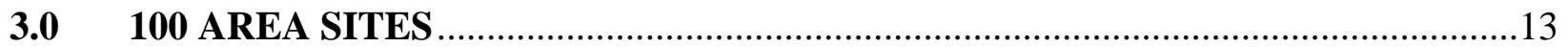

3.1 HANFORD GENERATING PLANT ...........................................................13

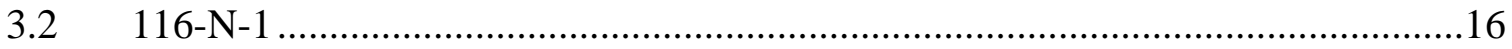

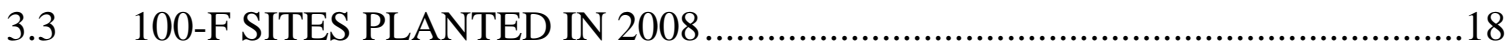

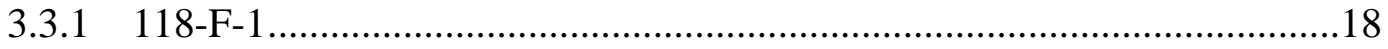

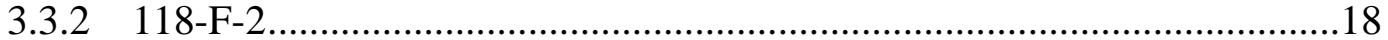

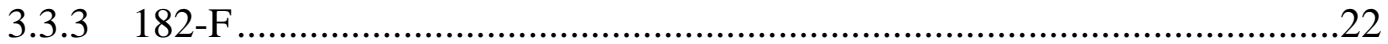

3.3.4 126-F-2 (183-F) East Clearwell ...........................................................25

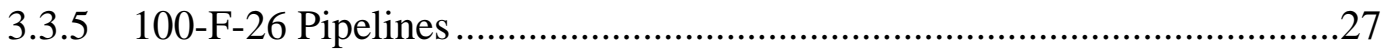

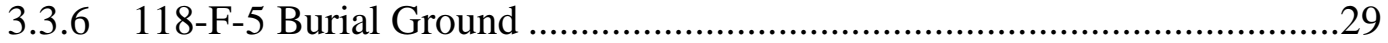

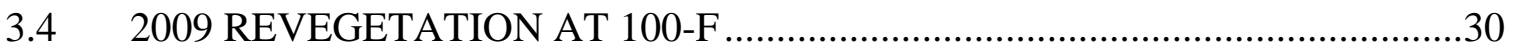

3.4.1 118-F-6 Burial Ground .......................................................................30

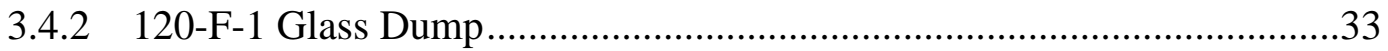

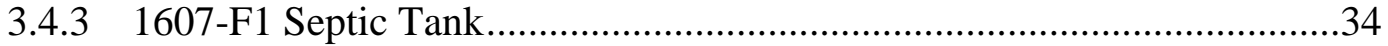

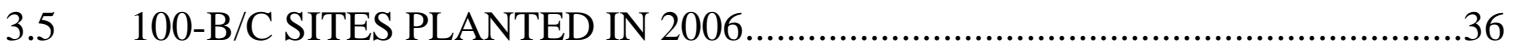

3.6 100-B/C SITES PLANTED IN 2007...........................................................42

3.7 100-B/C SITES PLANTED IN 2008............................................................44

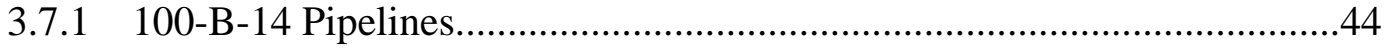

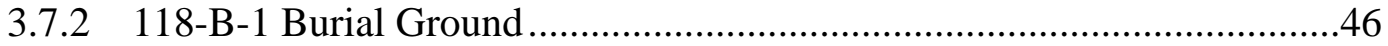

3.7.3 118-C-1 Burial Ground ........................................................................48 
3.8 100-B/C SITES PLANTED IN 2009....................................................49

3.8.1 100-B-28 Sodium Dichromate Transfer Pipeline ....................................50

3.8.2 100-B-27 Sodium Dichromate Spill ....................................................51

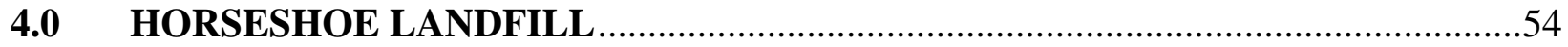

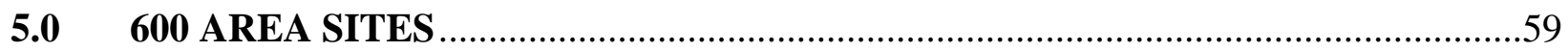

$5.1 \quad 600-111$ CRITICALITY MASS LABORATORY ...........................................59

$5.2 \quad 600-149: 2$ SMALL ARMS RANGE ...........................................................62

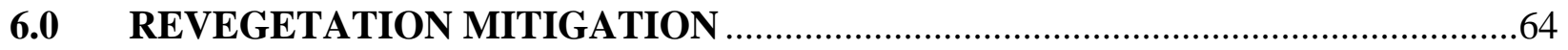

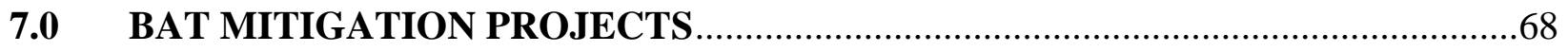

7.1 BAT MITIGATION AT 100-D AREA ......................................................68

7.2 BAT MITIGATION AT 100-F REACTOR ….................................................73

7.3 183-F CLEARWELL MATERNITY COLONY ............................................76

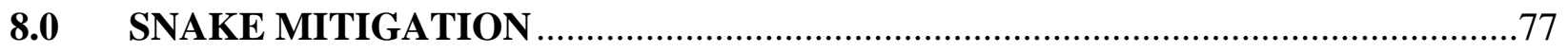

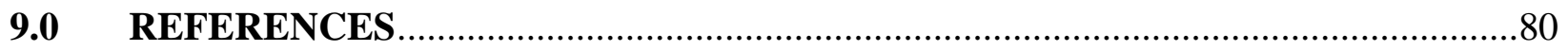

\section{APPENDICES}

A. 2008 REVEGETATION MONITORING RESULTS ............................................... A-i

B. 2007 REVEGETATION MONITORING RESULTS ............................................. B-i

C. $\quad 2006$ REVEGETATION MONITORING RESULTS ............................................. C-i

D. 2005 REVEGETATION MONITORING RESULTS .............................................. D-i

E. NAME CHANGES INCLUDED IN INTEGRATED TAXONOMIC

INFORMATION SYSTEM ............................................................................

\section{FIGURES}

1. Hanford Site Showing Locations of Revegetation Sites............................................. 2

2. $\quad 300-8$ Aluminum Shavings Waste Site in 2010 .................................................. 5

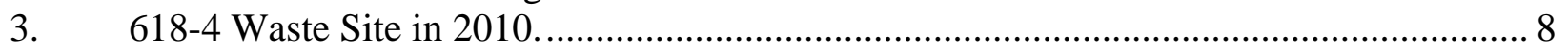

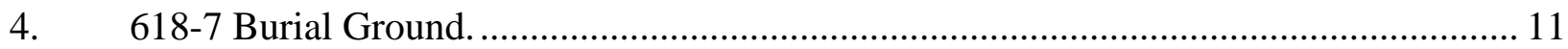

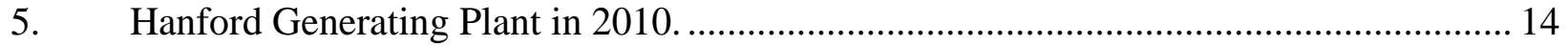

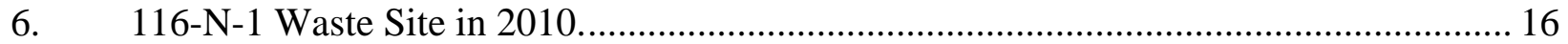

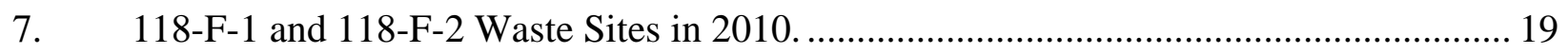

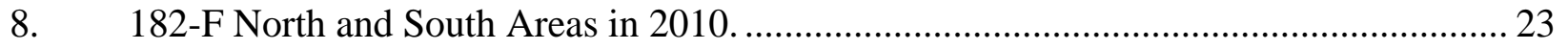




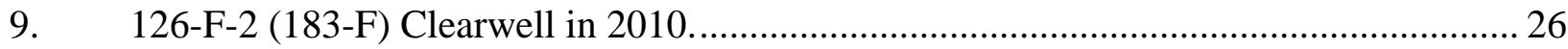

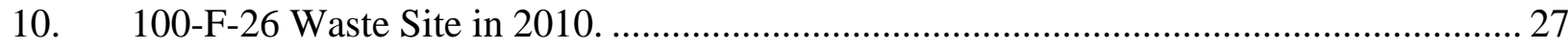

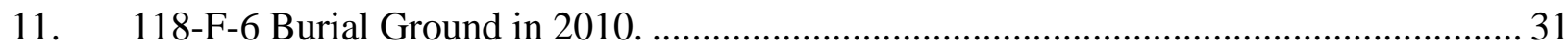

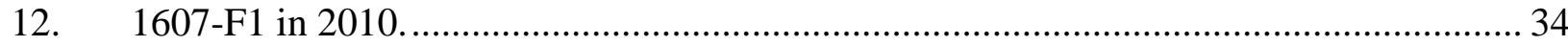

13. Canopy Cover Changes of Selected Species Over Time at 100-B-1............................. 37

14. Canopy Cover Changes of Selected Species Over Time at 128-C-1............................ 38

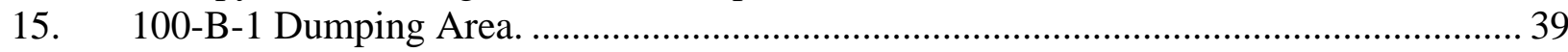

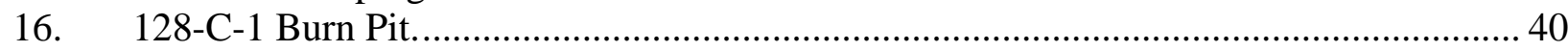

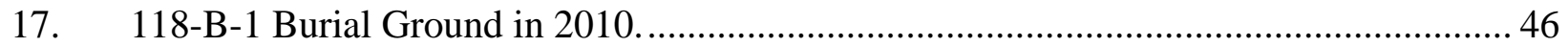

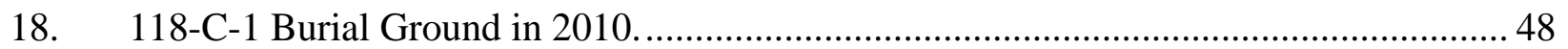

19. 100-B-28 Sodium Dichromate Transfer Pipeline in 2010 ........................................... 50

20. 100-B-27 Sodium Dichromate Spill Site in 2010 ................................................... 52

21. Revegetation of the Horseshoe Landfill and Soil Staging Area. ................................... 56

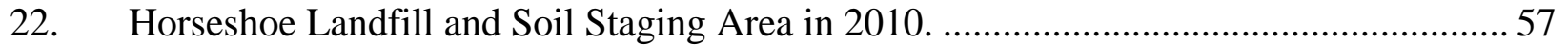

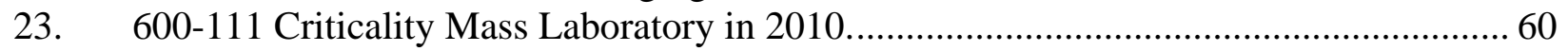

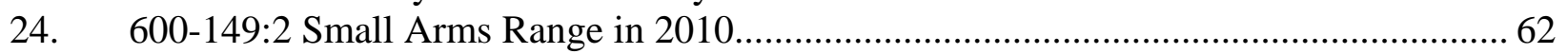

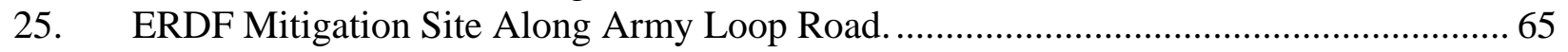

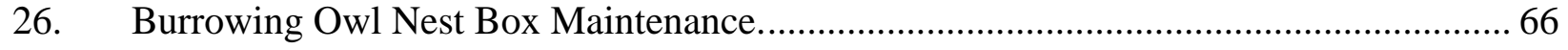

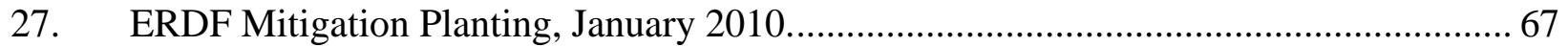

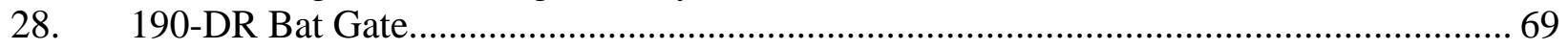

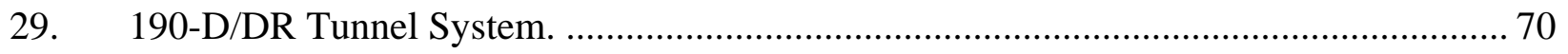

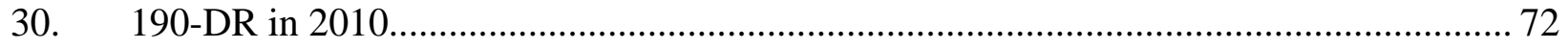

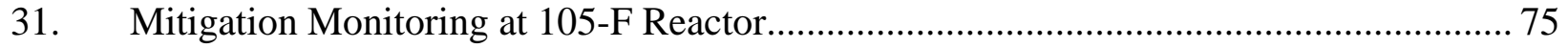

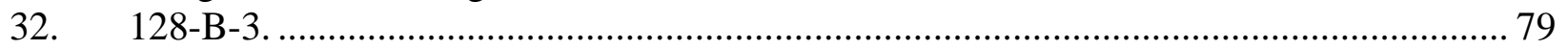

\section{TABLES}

1. Percent Canopy Cover and Frequency of Occurrence at 300-8 in 2010......................... 5

2. $\quad 618-4$ Sagebrush Monitoring Results...................................................................... 7

3. Percent Canopy Cover and Frequency of Occurrence at the 618-7 Burial Ground

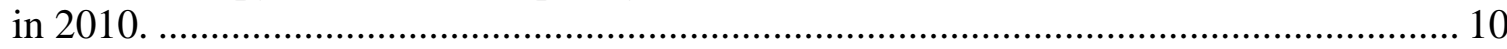

4. Percent Canopy Cover and Frequency of Occurrence at 618-13 in 2010....................... 12

5. Percent Canopy Cover and Frequency of Occurrence at Hanford Generating Plant

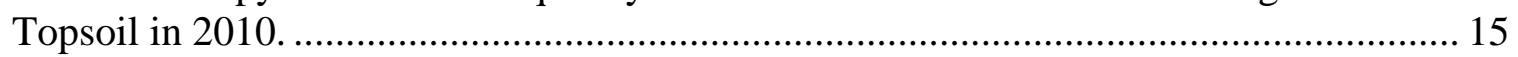

6. Percent Canopy Cover and Frequency of Occurrence at 116-N-1 in 2010................... 17

7. Percent Canopy Cover and Frequency of Occurrence at 118-F-1 in 2010 ..................... 20

8. Percent Canopy Cover and Frequency of Occurrence at 118-F-2 in 2010..................... 21

9. Percent Canopy Cover and Frequency of Occurrence at 182-F in 2010 ........................ 24

10. Percent Canopy Cover and Frequency of Occurrence at 126-F-2 in 2010 ..................... 25

11. Percent Canopy Cover and Frequency of Occurrence at 100-F-26 in 2010................... 28

12. Percent Canopy Cover and Frequency of Occurrence at 118-F-5 in 2010 ..................... 29

13. Percent Canopy Cover and Frequency of Occurrence at 118-F-6 in 2010 ...................... 32

14. Percent Canopy Cover and Frequency of Occurrence at 120-F-1 in 2010 ..................... 33

15. Percent Canopy Cover and Frequency of Occurrence at 1607-F1 in 2010 .................... 35 
16. Percent Canopy Cover and Frequency of Occurrence at 100-B-1 and 128-C-1 in 2010. 41

17. Percent Canopy Cover and Frequency of Occurrence at 100-C-9 in 2010..................... 43

18. Percent Canopy Cover and Frequency of Occurrence at 100-B-14 in 2010................... 45

19. Percent Canopy Cover and Frequency of Occurrence at 118-B-1 in 2010..................... 47

20. Percent Canopy Cover and Frequency of Occurrence at 118-C-1 in 2010..................... 49

21. Percent Canopy Cover and Frequency of Occurrence at 100-B-28 in 2010................... 51

22. Percent Canopy Cover and Frequency of Occurrence at 100-B-27 in 2010.................. 53

23. Percent Canopy Cover and Frequency of Occurrence at Horseshoe Landfill and Soil

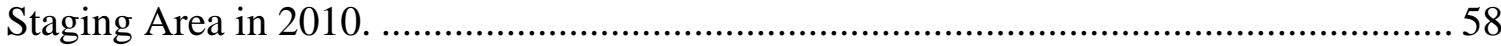

24. Percent Canopy Cover and Frequency of Occurrence at 600-111 in 2010.................... 61

25. Percent Canopy Cover and Frequency of Occurrence at 600-149:2 in 2010................. 63 


\section{METRIC CONVERSION CHART}

\begin{tabular}{|c|c|c|c|c|c|}
\hline \multicolumn{3}{|c|}{ Into Metric Units } & \multicolumn{3}{|c|}{ Out of Metric Units } \\
\hline If You Know & Multiply By & To Get & If You Know & Multiply By & To Get \\
\hline Length & & & Length & & \\
\hline inches & 25.4 & Millimeters & Millimeters & 0.039 & Inches \\
\hline inches & 2.54 & Centimeters & Centimeters & 0.394 & Inches \\
\hline feet & 0.305 & Meters & Meters & 3.281 & feet \\
\hline yards & 0.914 & Meters & Meters & 1.094 & yards \\
\hline miles & 1.609 & Kilometers & Kilometers & 0.621 & miles \\
\hline Area & & & Area & & \\
\hline sq. inches & 6.452 & sq. centimeters & sq. centimeters & 0.155 & sq. inches \\
\hline sq. feet & 0.093 & sq. meters & sq. meters & 10.76 & sq. feet \\
\hline sq. yards & 0.0836 & sq. meters & sq. meters & 1.196 & sq. yards \\
\hline sq. miles & 2.6 & sq. kilometers & sq. kilometers & 0.4 & sq. miles \\
\hline acres & 0.405 & hectares & Hectares & 2.47 & acres \\
\hline Mass (weight) & & & Mass (weight) & & \\
\hline ounces & 28.35 & grams & Grams & 0.035 & ounces \\
\hline pounds & 0.454 & kilograms & Kilograms & 2.205 & pounds \\
\hline ton & 0.907 & metric ton & metric ton & 1.102 & ton \\
\hline Volume & & & Volume & & \\
\hline teaspoons & 5 & milliliters & Milliliters & 0.033 & fluid ounces \\
\hline tablespoons & 15 & milliliters & Liters & 2.1 & pints \\
\hline fluid ounces & 30 & milliliters & Liters & 1.057 & quarts \\
\hline cups & 0.24 & liters & Liters & 0.264 & gallons \\
\hline pints & 0.47 & liters & cubic meters & 35.315 & cubic feet \\
\hline quarts & 0.95 & liters & cubic meters & 1.308 & cubic yards \\
\hline gallons & 3.8 & liters & & & \\
\hline cubic feet & 0.028 & cubic meters & & & \\
\hline cubic yards & 0.765 & cubic meters & & & \\
\hline Temperature & & & Temperature & & \\
\hline Fahrenheit & $\begin{array}{l}\text { subtract } 32 \text {, } \\
\text { then multiply } \\
\text { by } 5 / 9\end{array}$ & Celsius & Celsius & $\begin{array}{l}\text { multiply by } \\
9 / 5 \text {, then add } \\
32\end{array}$ & Fahrenheit \\
\hline
\end{tabular}


WCH-428

Rev. 0

2010 River Corridor Closure Contractor Revegetation and Mitigation Monitoring Report 


\subsection{INTRODUCTION}

This report documents the status of revegetation projects and natural resources mitigation efforts conducted for remediated waste sites and other activities associated with the Comprehensive Environmental Response, Compensation, and Liability Act of 1980 (CERCLA) cleanup of National Priorities List waste sites at Hanford. This report contains the vegetation monitoring data that were collected in the spring and summer of 2010 from the River Corridor Closure Contractor's (RCCC) revegetation and mitigation areas on the Hanford Site.

The extent of each revegetation effort varied depending on the surrounding habitat, existing conditions, and future land-use designation of the area. The purpose of monitoring revegetation efforts is to measure the progress of plant succession and to evaluate the success of different planting techniques to improve RCCC site restoration success. Each area will be discussed separately and will include a brief description of the revegetation activities and the results from the 2010 monitoring efforts.

This report provides fifth-year survey results for the revegetated areas at the Hanford Generating Plant at the 100-N Area, 618-4 Burial Ground sagebrush planting, Horseshoe Landfill on the Arid Lands Ecology (ALE) Reserve, 128-C-1, and 100-B-1. Fourth-year monitoring results are included from 300-8, 618-4, 116-N-1, 100-C-9, and 118-B-2\&3. Third-year monitoring was conducted at 182-F, 118-F-2, 118-F-1, 126-F-2, 100-F-26, 118-F-5, 118-C-1, 100-B-14, and 118-B-1. Second-year monitoring was performed at 118-F-6, 120-F-1, 1607-F1, 618-7, 600-111, and 600-149. Finally, first-year monitoring was performed at 618-13, 100-B-27, 100-B-28, and Environmental Restoration Disposal Facility (ERDF) mitigation for Super Cell 9 (Figure 1).

Results from previous years' monitoring are provided in reports for each respective year (Lindsey et al. 2009, Lindsey and Gano 2008, Gano and Lindsey 2007, and Johnson and Gano 2006). The data tables from the previous revegetation monitoring reports are in Appendices $A$, $\mathrm{B}, \mathrm{C}$, and $\mathrm{D}$ of this report.

\subsection{METHODS USED TO EVALUATE VEGETATION RECOVERY}

Monitoring of revegetation and mitigation areas consisted of measuring the canopy cover of all plant species found on a site; the frequency of occurrence; and the survival of transplanted sagebrush (Artemisia tridentata), bitterbrush (Purshia tridentata), and spiny hopsage (Grayia spinosa) seedlings. All values were then converted to percentages. Canopy cover and frequency measurements were obtained using the methods described in Steppe Vegetation of Washington (Daubenmire 1970). Canopy coverage is defined in Daubenmire (1970) as "the percentage of ground surface included in the vertical projection of a polygon drawn around the extremities of undisturbed foliage of a plant.” This method provides a measure of the amount of ground covered by each species. Because it is possible, in dense stands of vegetation for species to overlap one another, total measured vegetative cover can exceed $100 \%$. Within each location, a series of plot frames was analyzed for the canopy cover of each species present. Frequency is 
Figure 1. Hanford Site Showing Locations of Revegetation Sites.

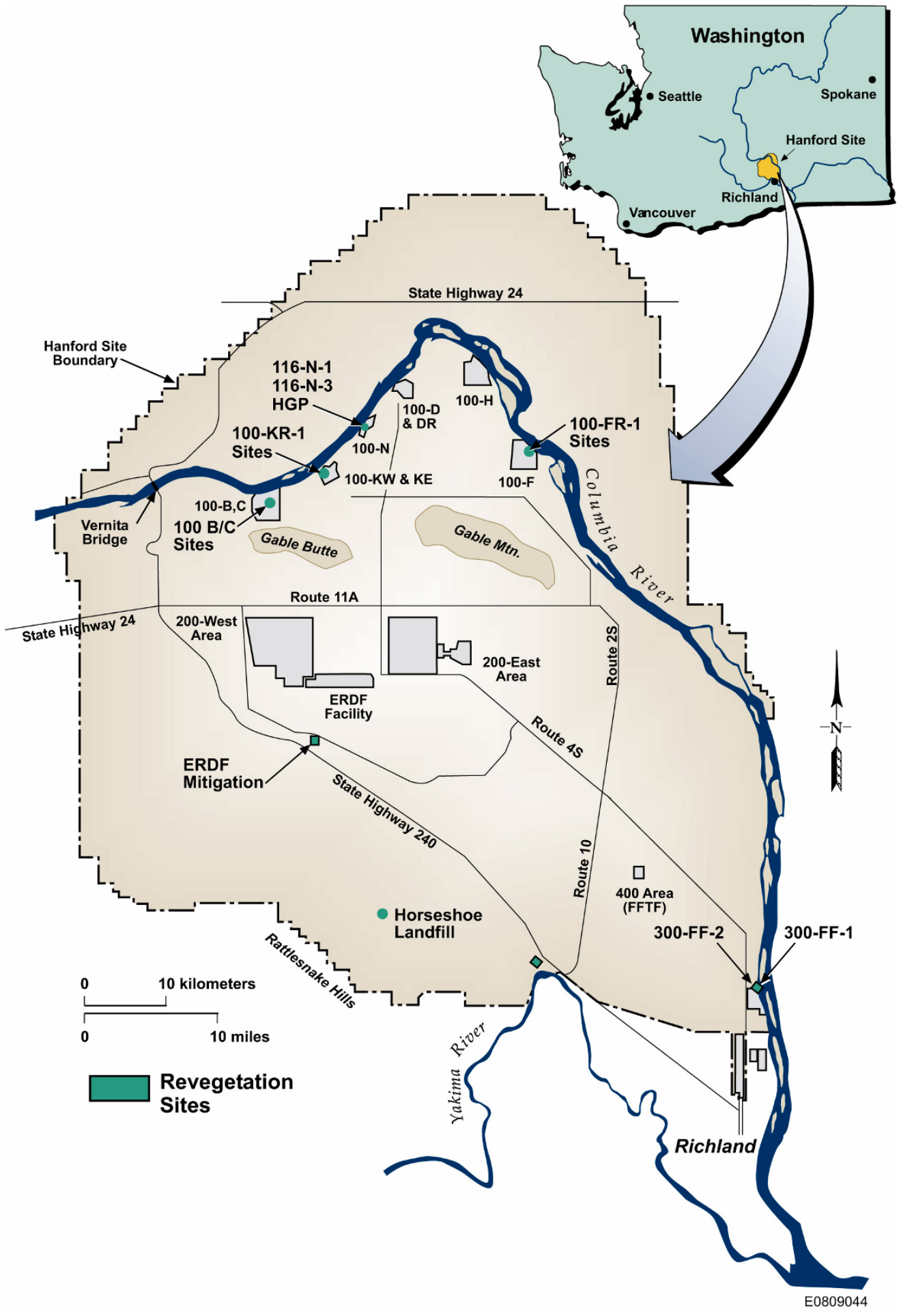


represented as the percentage of occurrences that a species is observed in the number of plot frames measured. For example, if a species was represented in 10 out of 25 plot frames, its frequency would be $10 / 25 \times 100=40 \%$. Species that were observed within a revegetated area, but were not counted in a plot frame, were recorded as occurrences in the data tables.

The relative magnitude of a frequency rating in comparison to a canopy coverage rating provides an index of species distribution and its influence within a vegetation community. At sites where shrubs were planted, survival was measured by counting a representative number of plants at the site, determining if the plants were dead or alive, and then calculating the percent survival.

This report uses taxonomic nomenclature from Flora of the Pacific Northwest (Hitchcock and Cronquist 1973). Some of the plant taxonomic names have been updated, and the revised names are provided in Appendix E of this report. Plant identification was conducted using the nomenclature in Hitchcock and Cronquist (1973) and also in Vascular Plants of the Hanford Site (Sackschewsky and Downs 2001).

The type and extent of each revegetation effort is based on the location of the project and the future land designation of that area. For example, portions of the 300 Area, including the 300-FF-1 Process Ponds and Burial Grounds restoration area, have been designated for future industrial use. Therefore, the objective of the revegetation effort is long-term interim stabilization. The Hanford Site Biological Resources Management Plan (BRMaP) (DOE-RL 2001) prescribes seeding crested wheatgrass (Agropyron cristatum); however, to increase species diversity over the 28.3-ha area, five additional grass species were planted. The objective of revegetation at most remedial action sites is to restore the land to plant communities that are dominated by native plants that will eventually provide wildlife habitat. Secondary objectives often include using different planting methods and techniques to improve success, while incorporating experience and knowledge gained from previous plantings.

Success criteria differ for each site with consideration of varying soil types and microclimatic conditions. For example, sandy areas promote different species with differing recovery rates and plant densities than those found in rocky soils; therefore, the criteria for judging success will be different. All sites will be evaluated based on the plant canopy cover, plant community composition, and survival and growth rates of the planted shrubs. These criteria are detailed in the Revegetation Manual for the Environmental Restoration Contractor (McLendon et al. 1997). A revegetation effort will be considered successful if the area is stabilized to prevent erosion and is dominated by recovering stands of native shrubs, forbs, and grasses. Areas identified for future industrial use may be stabilized with wheatgrass (Agropyron) varieties because of the potential for future land disturbance.

According to the Hanford Meteorological Station, the Hanford Site experienced below-average temperatures during the spring of 2010. The average temperature for April was 0.3 degrees below normal, May was 3.9 degrees below normal, and June was 2.4 degrees below normal. Across many of the sites monitored during 2010, overall canopy cover was observed to be down significantly from those levels observed in 2009. The departure from normal temperatures may have been a significant factor in this observed change, delaying growth until later in the spring 
than usual. It is not expected that the reduction across the sites would have been due to the loss of stem density of any species, but subsequent monitoring at these sites in 2011 may help to explain this phenomenon.

\subsection{AREA}

Remediation of the 618-4 Burial Ground was completed in 2004, along with other 300-FF-1 Operable Unit waste sites, and was planted in February 2006. Remediation in the 300-FF-2 Operable Unit began in 2004 with the remediation of the 300-8 Aluminum Shavings waste site, 600-47, and the 300-18 waste sites. Remediation at the 618-7 Burial Ground began in 2007 and was completed and revegetated in December 2008. Remediation of the 618-13 Burial Ground was initiated in January 2009 and continued for approximately 2 months. The site was revegetated in January 2010.

\section{$2.1 \quad 300-8$ ALUMINUM SHAVINGS}

The 300-8 Aluminum Shavings site remediation included scraping the top $2 \mathrm{ft}$ of soil and debris from the surface. The excavations were not backfilled but recontoured to blend with the adjacent area. The site was broadcast seeded with a mixture of crested and bluebunch wheat grasses and mulched with straw the first week of January 2007.

Fourth-year monitoring was conducted at the 300-8 site on April 28, 2010 (Figure 2). The purpose of this revegetation remains interim stabilization; however, native plants have also become established at the site. Sandberg's bluegrass continues to increase in canopy cover, up to 4.3\% during the 2010 monitoring (Table 1). Native species make up a relatively low canopy cover, at $7.9 \%$, but 13 native species are present. This high diversity is due to the intact sagebrush habitat that exists adjacent to the site. This shows the importance of maintaining even small sections of established habitat within or adjacent to remediation areas. 
Figure 2. 300-8 Aluminum Shavings Waste Site in 2010.

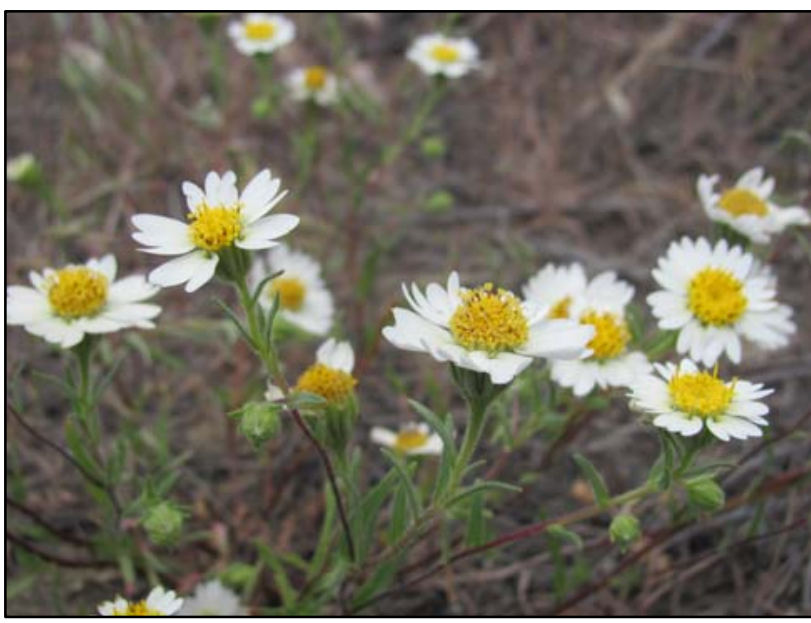

White-daisy tidytips growing at 300-8.

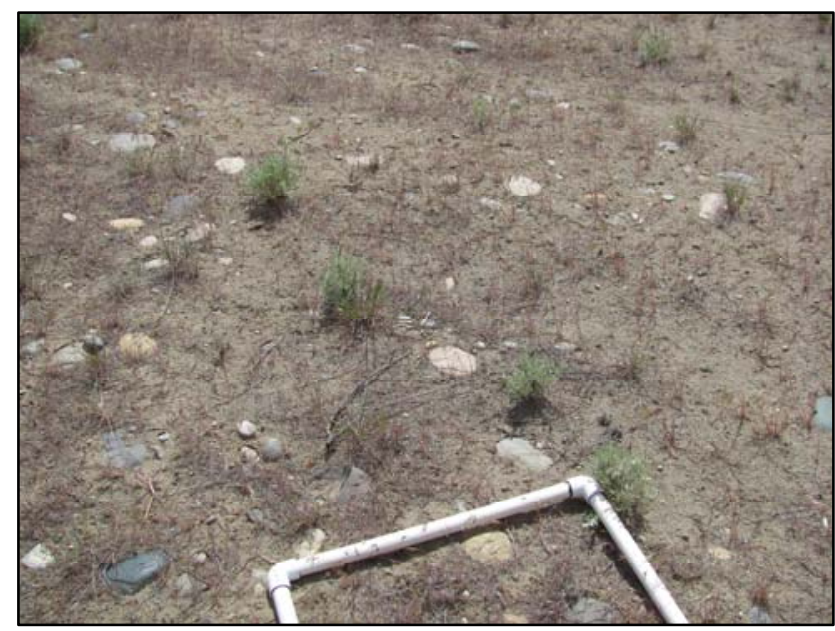

Volunteer sagebrush recruits growing at 300-8.

Table 1. Percent Canopy Cover and Frequency of Occurrence at 300-8 in 2010. (2 Pages)

\begin{tabular}{|c|c|c|}
\hline Species & \% Cover & $\%$ Freq of Occ \\
\hline Bromus tectorum ${ }^{\text {a }}$ (cheatgrass) & 56.1 & 100.0 \\
\hline Agropyron cristatum ${ }^{\mathrm{a}}$ (crested wheatgrass) & 8.9 & 68.0 \\
\hline Poa sandbergii (Sandberg's bluegrass) & 4.3 & 56.0 \\
\hline Salsola kali $^{\mathrm{a}}$ (Russian thistle) & 1.7 & 68.0 \\
\hline Holosteum umbellatum ${ }^{\mathrm{a}}$ (jagged chickweed) & 1.4 & 56.0 \\
\hline Chrysothamnus nauseosus (gray rabbitbrush) & 1.4 & 36.0 \\
\hline Draba verna $^{\text {a }}$ (spring whitlowgrass) & 1.0 & 40.0 \\
\hline Festuca octoflora (slender sixweeks) & 0.5 & 20.0 \\
\hline Oryzopsis hymenoides (Indian ricegrass) & 0.4 & 16.0 \\
\hline Artemisia tridentata (big sagebrush) & 0.2 & 8.0 \\
\hline Machaeranthera canescens (hoary aster) & 0.2 & 8.0 \\
\hline Sisymbrium altissimum ${ }^{\mathrm{a}}$ (tumble mustard) & 0.1 & 4.0 \\
\hline Plantago patagonica (Indian wheat) & 0.1 & 4.0 \\
\hline Oenothera pallida (pale eveningprimrose) & 0.1 & 4.0 \\
\hline Hymenopappus filifolius (Columbia cutleaf) & $\mathrm{X}$ & $\mathrm{X}$ \\
\hline Melilotus alba ${ }^{\mathrm{a}}$ (sweetclover) & $\mathrm{X}$ & $\mathrm{X}$ \\
\hline Centaurea diffusa ${ }^{\mathrm{a}}$ (diffuse knapweed) & $\mathrm{X}$ & $\mathrm{X}$ \\
\hline Erodium cicutarium $^{\mathrm{a}}$ (storksbill) & $\mathrm{X}$ & $\mathrm{X}$ \\
\hline Amsinckia lycopsoides (tarweed fiddleneck) & $\mathrm{X}$ & $\mathrm{X}$ \\
\hline Balsamorhiza careyana (Carey's balsamroot) & $\mathrm{X}$ & $\mathrm{X}$ \\
\hline Chondrilla juncea $^{\mathrm{a}}$ (rush skeletonweed) & $\mathrm{X}$ & $\mathrm{X}$ \\
\hline Eriogonum niveum (snow buckwheat) & $\mathrm{X}$ & $\mathrm{X}$ \\
\hline
\end{tabular}


Table 1. Percent Canopy Cover and Frequency of Occurrence at 300-8 in 2010. (2 Pages)

\begin{tabular}{lcc}
\hline \multicolumn{1}{c}{ Species } & \% Cover & \% Freq of Occ \\
\hline Layia glandulosa (white-daisy tidytips) & $\mathrm{X}$ & $\mathrm{X}$ \\
Poa bulbosa $^{\text {a }}$ (bulbous bluegrass) & $\mathrm{X}$ & $\mathrm{X}$ \\
Biotic crust & 8.5 & 88.0 \\
Bare soil & 49.3 & 100.0 \\
Litter & 45.7 & 96.0 \\
\hline Total canopy cover (litter not included) & 76.4 & \\
a Invasive species & & \\
X = present but not counted in plot frames & & \\
Total Invasive \% Cover & 72.8 & \\
Total Native \% Cover & 7.9 & \\
Change in Native \% Cover from 2009 & +2.9 &
\end{tabular}

\section{$2.2 \quad$ 618-4 BURIAL GROUND}

The 618-4 Burial Ground is located outside of the area that was zoned for industrial use; therefore, this site was planted with sagebrush tubelings during the first week of February 2006. Three shrub survival monitoring transects (T1, T2, T3) were established in April 2006 to capture baseline survival counts.

Fourth-year monitoring was conducted at the 618-4 Burial Ground in April 2010. Shrub survival remains high at this site, and survival rates have stabilized. Monitoring results are shown in Table 2. Overall shrub survival across the transects is 57\%, and many shrubs are blooming and producing seed annually. Eighteen native species were observed on the site, including shrubs, grasses, and forbs (Figure 3). The adjacent native communities, and the native topsoil that was salvaged at this site, provided a seed source that has allowed such a diverse community to become established. 
Table 2. 618-4 Sagebrush Monitoring Results.

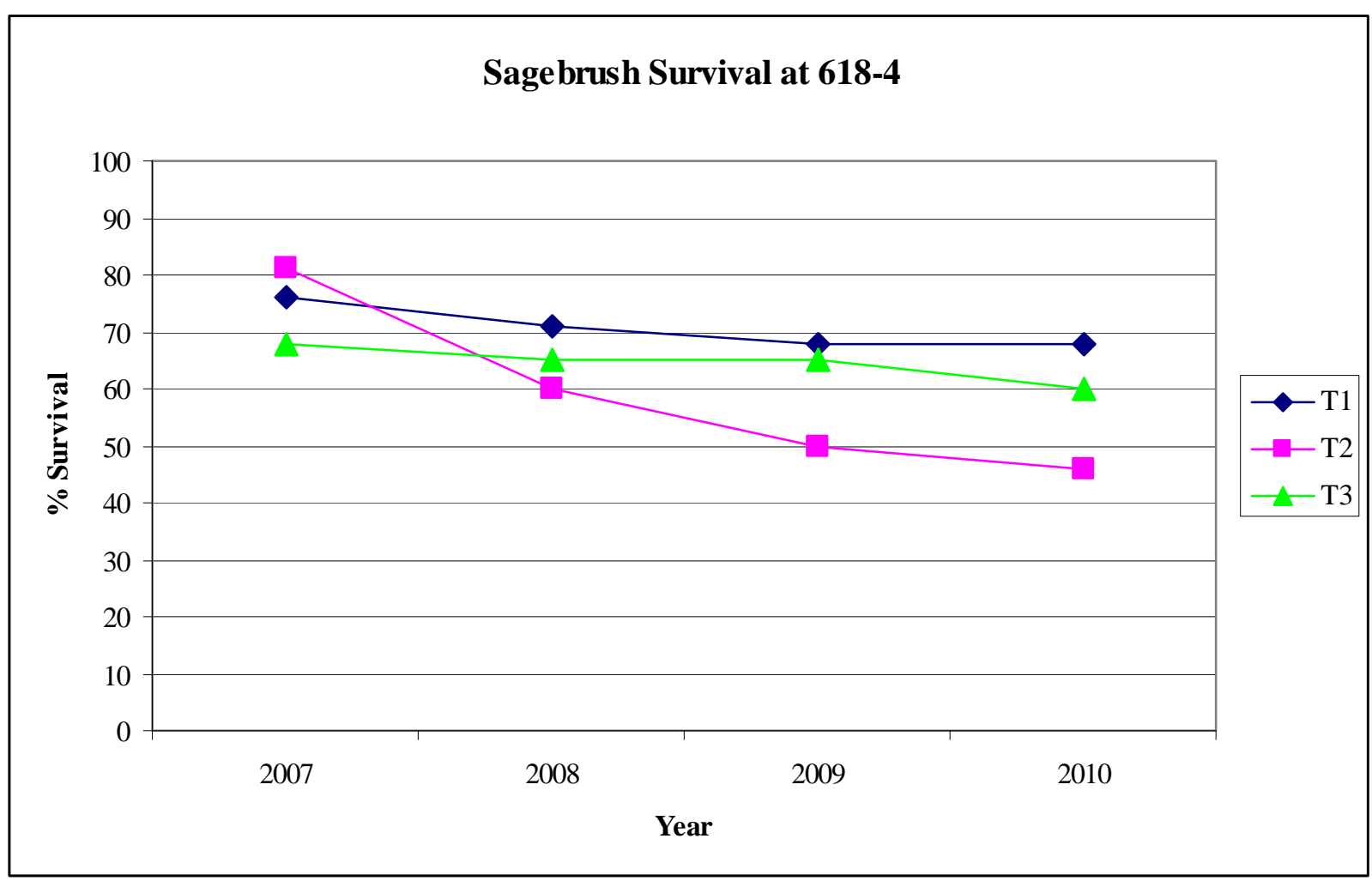


Figure 3. 618-4 Waste Site in 2010.

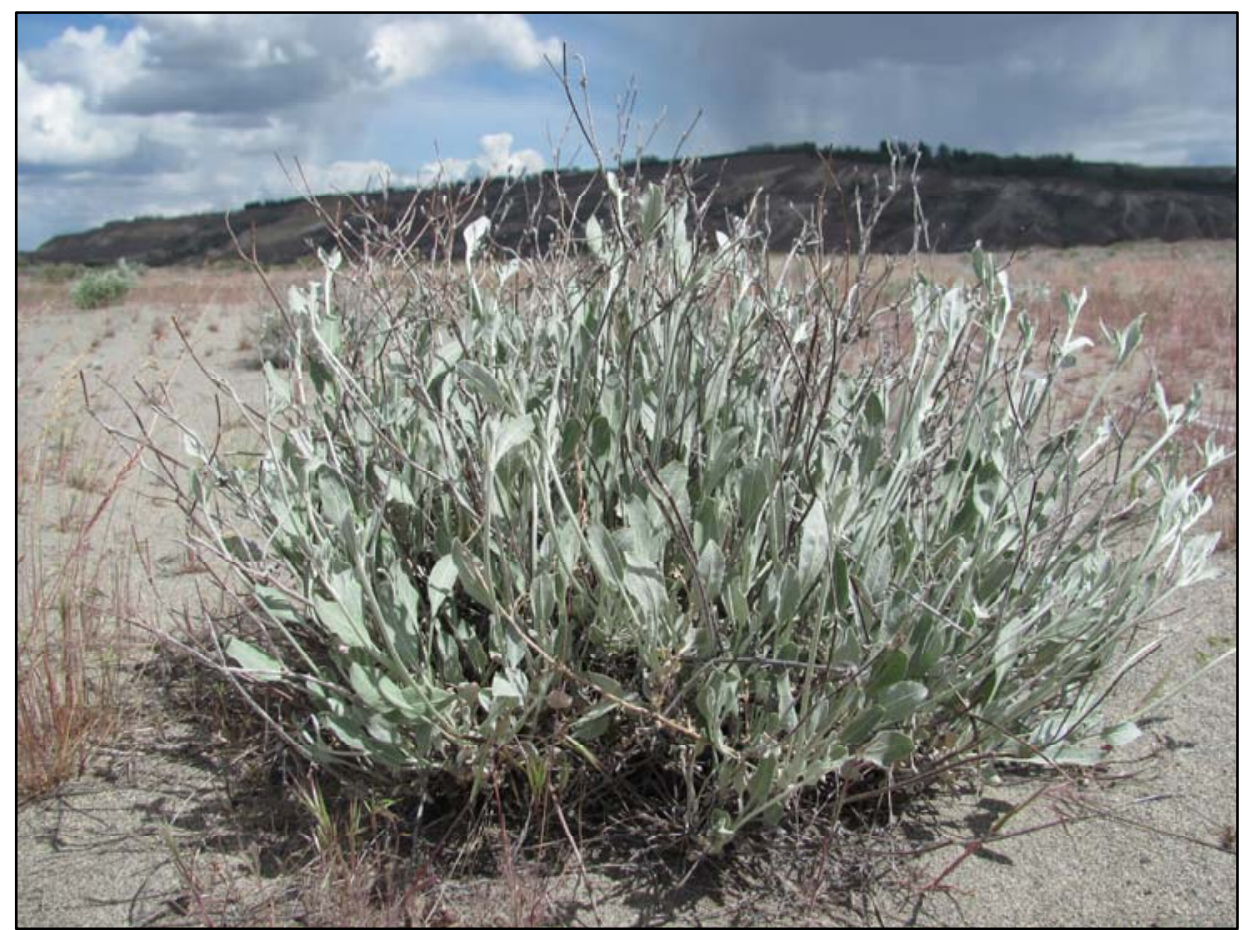

Volunteer snow buckwheat growing at the 618-4 Burial Ground.

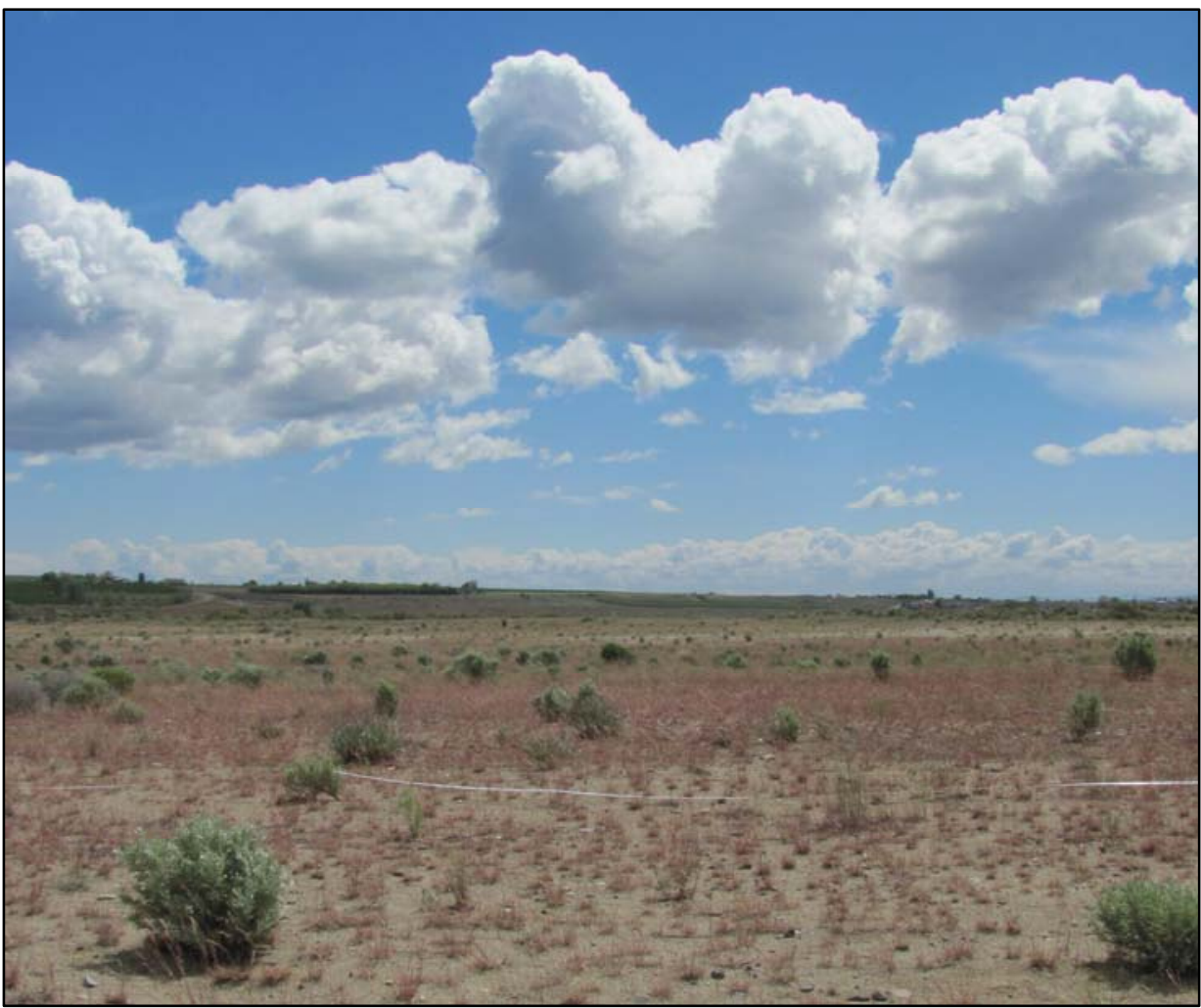

Planted Sandberg's bluegrass and sagebrush at the 618-4 Burial Ground. 


\section{$2.3 \quad$ 618-7 BURIAL GROUND}

The 618-7 site was broken down into three areas for monitoring, to show variation between the different portions of the plot. The container transfer area (CTA) was treated as a separate site, and the burial ground was split to have a north and south transect. The north transect has a ground surface consisting of fist-sized cobbles, while the south transect received a top dressing of fine-grained soil that was salvaged from the CTA area prior to the installation of the CTA. These areas were broadcast seeded with a mixture of native grasses including Sandberg's bluegrass, Indian ricegrass, bluebunch wheatgrass, prairie junegrass, bottlebrush squirreltail, and needle-and-thread grass. In addition, $134 \mathrm{~kg} / \mathrm{ha}$ of Triple-16 fertilizer was added to the sites along with 4,480 kg/ha of straw mulch that was spread and crimped into the soil surface. Sagebrush and bitterbrush plugs were then planted into the seeded areas at 1,235 plants/ha.

The majority of the planted CTA area was bladed and graveled as part of a project not associated with the RCCC. As such, monitoring was not conducted at that portion of the 618-7 site. Second-year monitoring was performed at the remainder of the 618-7 site on April 29, 2010. For the first time, a planted species (Sandberg's bluegrass) was recorded as the dominant species for canopy cover (Table 3). Native canopy cover increased significantly at both the north cobble and south topsoil transects, up $22 \%$ at the north cobble portion to $28 \%$ native canopy cover, and up $33 \%$ at the south topsoil portion to $54 \%$ native canopy cover. The majority of this increase is accounted for by the increase in Sandberg's bluegrass, but a total of 15 native species were recorded on the site in 2010. Invasive species cover remains low, about 15\%, for both the North cobble and south topsoil sites. Fifteen native species were observed on the topsoil site, while the cobble site supported 10 native species. This difference is likely due to the seedbank present in the topsoil, and because many species are better adapted to growing in topsoil than large rivercobble.

The established sagebrush monitoring transect was evaluated for shrub survival on September 29, 2010. The transect measures $100.3 \mathrm{~m}$ long and is located within the southern portion of the site. Transect monitoring estimates sagebrush survival at $88 \%$ and bitterbrush survival at 50\%. Of the sagebrush seedlings still alive, $26.7 \%$ of them are blooming this year (Figure 4). 
Table 3. Percent Canopy Cover and Frequency of Occurrence at the 618-7 Burial Ground in 2010.

\begin{tabular}{|c|c|c|c|c|}
\hline Species & $\begin{array}{c}\% \text { Cover } \\
\text { North Cobble } \\
\end{array}$ & $\begin{array}{l}\text { \% Freq of Occ } \\
\text { North Cobble }\end{array}$ & $\begin{array}{c}\% \text { Cover } \\
\text { South Topsoil } \\
\end{array}$ & $\begin{array}{l}\text { \% Freq of Occ } \\
\text { South Topsoil } \\
\end{array}$ \\
\hline Poa sandbergii (Sandberg's bluegrass) & 22.9 & 100.0 & 50.4 & 100.0 \\
\hline Bromus tectorum $^{\text {a } \text { (cheatgrass) }}$ & 3.2 & 68.0 & 11.4 & 88.0 \\
\hline Salsola kali $^{\mathrm{a}}$ (Russian thistle) & 8.9 & 100.0 & 1.7 & 68.0 \\
\hline Agropyron spicatum (bluebunch wheatgrass) & 2.5 & 60.0 & 1.2 & 48.0 \\
\hline Sisymbrium altissimum ${ }^{\mathrm{a}}$ (tumble mustard) & 2.5 & 60.0 & 0.9 & 36.0 \\
\hline Sitanion hystrix (bottlebrush squirreltail) & 2 & 60.0 & 0.7 & 8.0 \\
\hline Artemisia tridentata (big sagebrush) & $\mathrm{X}$ & $\mathrm{X}$ & 0.6 & 4.0 \\
\hline Oryzopsis hymenoides (Indian ricegrass) & 0.7 & 28.0 & 0.6 & 24.0 \\
\hline Lactuca serriola $^{\mathrm{a}}$ (prickly lettuce) & 0.5 & 20.0 & $\mathrm{X}$ & $\mathrm{X}$ \\
\hline Erodium cicutarium ${ }^{\mathrm{a}}$ (storksbill) & -- & -- & 0.4 & 16.0 \\
\hline Draba verna ${ }^{\mathrm{a}}$ (spring whitlowgrass) & 0.2 & 8.0 & 0.2 & 8.0 \\
\hline Vulpia myuros ${ }^{\mathrm{a}}$ (rattail fescue) & 0.2 & 8.0 & -- & -- \\
\hline Ambrosia acanthicarpa (bur ragweed) & 0.2 & 8.0 & -- & -- \\
\hline Holosteum umbellatum ${ }^{\mathrm{a}}$ (jagged chickweed) & -- & -- & 0.1 & 4.0 \\
\hline Chrysothamnus nauseosus (gray rabbitbrush) & $\mathrm{X}$ & $\mathrm{X}$ & 0.1 & 40 \\
\hline Poa bulbosa $a^{\text {a }}$ (bulbous bluegrass) & -- & -- & 0.1 & 4.0 \\
\hline Festuca octoflora (slender sixweeks) & -- & -- & 0.1 & 4.0 \\
\hline Descurainia pinnata (western tansymustard) & -- & -- & 0.1 & 4.0 \\
\hline Machaeranthera canescens (hoary aster) & -- & -- & $\mathrm{X}$ & $\mathrm{X}$ \\
\hline Hordeum leporinum (hare barley) & -- & -- & $\mathrm{X}$ & $\mathrm{X}$ \\
\hline Gilia leptomeria (Great Basin gilia) & -- & -- & $\mathrm{X}$ & $\mathrm{X}$ \\
\hline Microsteris gracilis (pink microsteris) & -- & -- & $\mathrm{X}$ & $\mathrm{X}$ \\
\hline Amsinckia lycopsoides (tarweed fiddleneck) & $\mathrm{X}$ & $\mathrm{X}$ & $\mathrm{X}$ & $\mathrm{X}$ \\
\hline Melilotus alba ${ }^{\mathrm{a}}$ (sweetclover) & $\mathrm{X}$ & $\mathrm{X}$ & $\mathrm{X}$ & $\mathrm{X}$ \\
\hline Grayia spinosa (spiny hopsage) & -- & -- & $\mathrm{X}$ & $\mathrm{X}$ \\
\hline Purshia tridentata (antelope bitterbrush) & -- & -- & $\mathrm{X}$ & $\mathrm{X}$ \\
\hline Eriogonum niveum (snow buckwheat) & $\mathrm{X}$ & $\mathrm{X}$ & -- & -- \\
\hline Grayia spinosa (spiny hopsage) & $\mathrm{X}$ & $\mathrm{X}$ & -- & -- \\
\hline Tragopogon dubius $^{\text {a }}$ (yellow salsify) & $\mathrm{X}$ & $\mathrm{X}$ & -- & -- \\
\hline Mentzelia albicaulis (whitestem stickleaf) & -- & -- & $\mathrm{X}$ & $\mathrm{X}$ \\
\hline Biotic crust & 0.0 & 0.0 & 0.0 & 0.0 \\
\hline Bare soil & 57.9 & 100.0 & 47.2 & 100.0 \\
\hline Litter & 33.4 & 100.0 & 46.6 & 100.0 \\
\hline Total canopy cover (litter not included) & 43.8 & & 68.6 & \\
\hline \multicolumn{5}{|l|}{$\begin{array}{l}{ }^{\mathrm{a}} \text { Invasive species } \\
\mathrm{X}=\text { present but not counted in plot frames }\end{array}$} \\
\hline Total Invasive \% Cover & 15.5 & & 14.8 & \\
\hline Total Native \% Cover & 28.3 & & 53.8 & \\
\hline Change in Native \% Cover from 2009 & +22.0 & & +32.8 & \\
\hline
\end{tabular}


Figure 4. 618-7 Burial Ground.

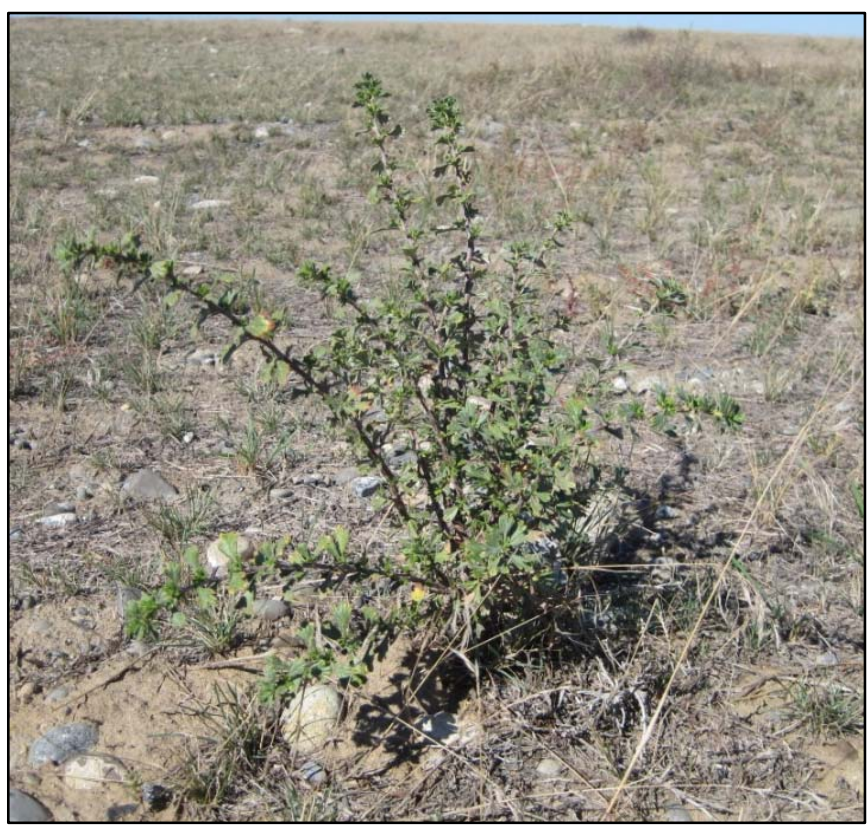

Planted bitterbrush on 618-7.

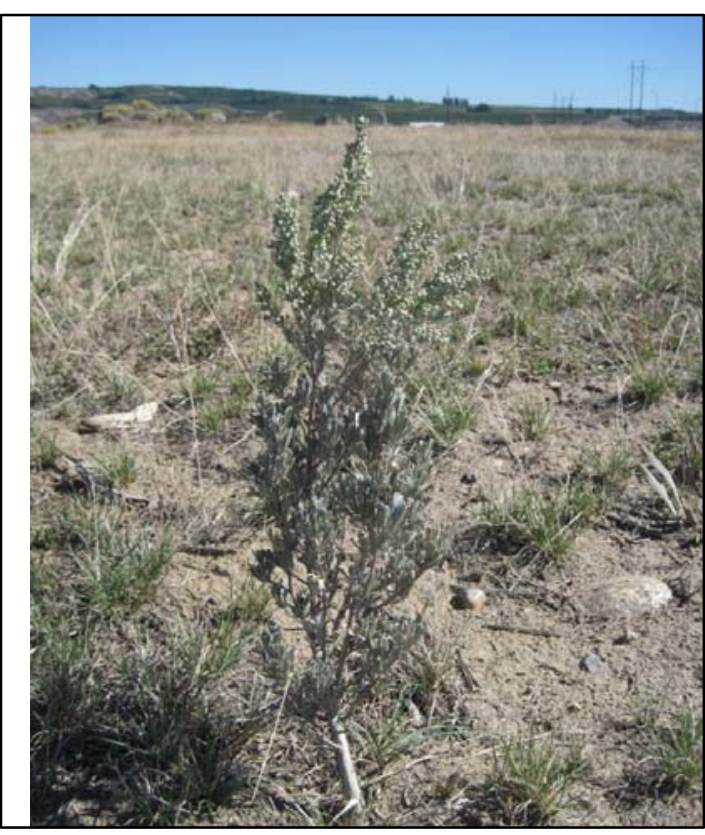

Planted sagebrush blooming on 618-7.

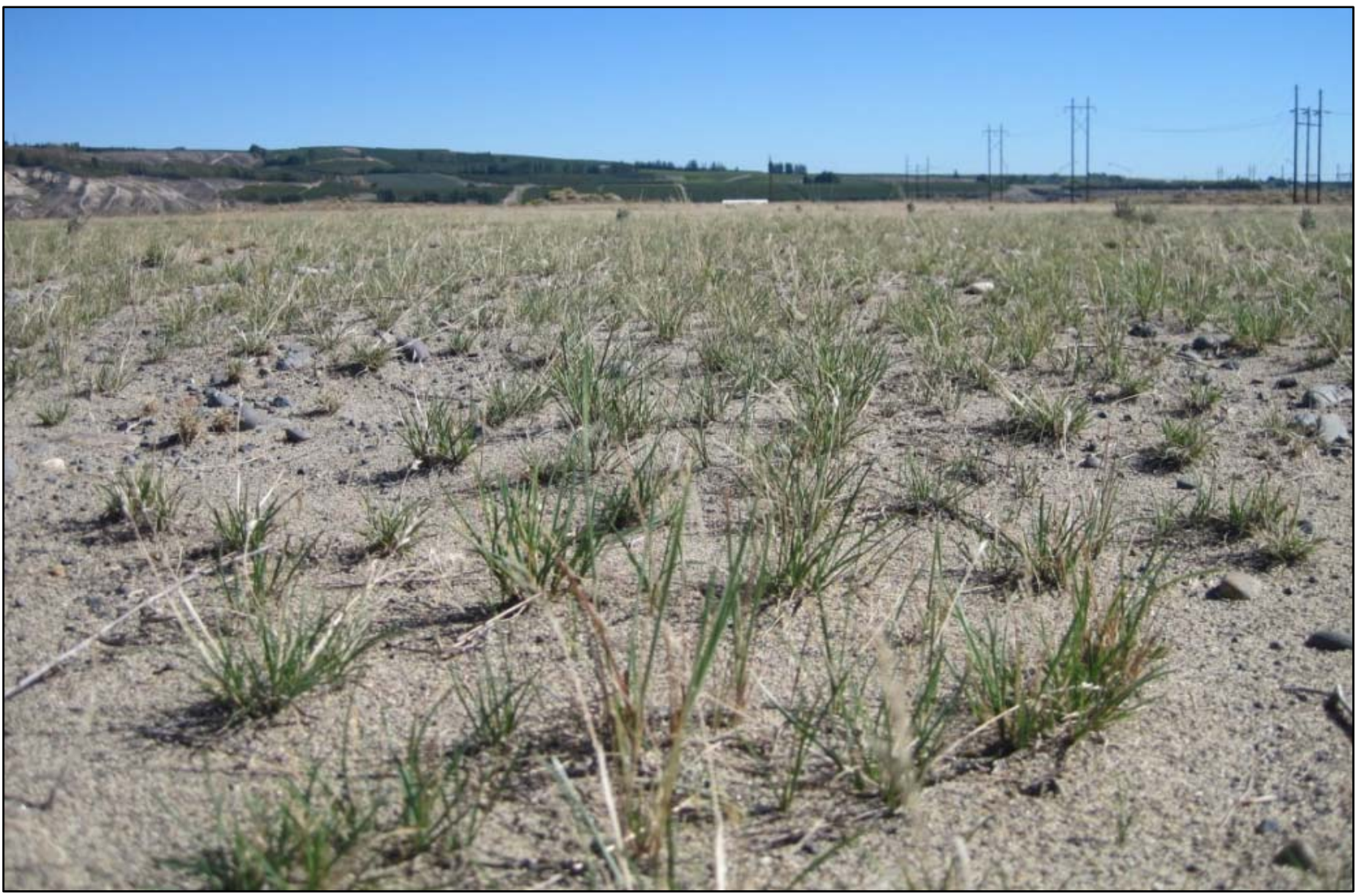

Planted grasses on 618-7. 


\section{$2.4 \quad$ 618-13 BURIAL GROUND}

The 618-13 Burial Ground consisted of a mound of soil approximately 4.6 to $6.1 \mathrm{~m}$ (15 to $20 \mathrm{ft}$ )

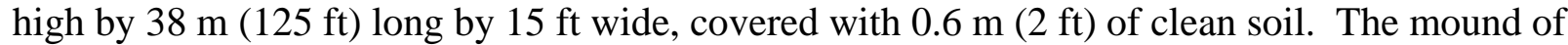
soil and debris was removed to grade and verified to be clean. The soil remaining at the site following removal of the mound is native sands and the seed bed for revegetation of the site. The area disturbed during remediation of the 618-13 Burial Ground was approximately one-half of an acre. The site was broadcast seeded with bluebunch wheatgrass, Sandberg's bluegrass, Indian ricegrass, needle-and-thread grass, and bottlebrush squirreltail grass seeds and planted with bitterbrush and sagebrush seedlings in mid-January 2010.

First-year monitoring of the 618-13 site was conducted on April 29, 2010. Sandberg's bluegrass was the dominate species on the site with 14.3\% cover followed by Russian thistle with $11.8 \%$ cover (Table 4). Three other native planted grasses, bluebunch wheatgrass, bottlebrush squirreltail, and Indian ricegrass, were also recorded on the site, yielding a total first-year cover for native bunchgrasses at $23.2 \%$. In addition to the native planted species, five additional native species were recorded or observed on the site, as well a volunteer sagebrush seedlings. Because the size of the site, a shrub monitoring transect was not established on the site.

Table 4. Percent Canopy Cover and Frequency of Occurrence at 618-13 in 2010.

\begin{tabular}{|c|c|c|}
\hline Species & \% Cover & $\%$ Freq of Occ \\
\hline Poa sandbergii (Sandberg's bluegrass) & 14.3 & 93.3 \\
\hline Salsola kali ${ }^{\mathrm{a}}$ (Russian thistle) & 11.8 & 86.7 \\
\hline Bromus tectorum ${ }^{\text {a }}$ (cheatgrass) & 9.8 & 66.7 \\
\hline Agropyron spicatum (bluebunch wheatgrass) & 6.3 & 86.7 \\
\hline Sisymbrium altissimum (tumble mustard) & 4.0 & 93.3 \\
\hline Sitanion hystrix (bottlebrush squirreltail) & 1.3 & 53.3 \\
\hline Oryzopsis hymenoides (Indian ricegrass) & 1.2 & 46.7 \\
\hline Artemisia tridentata (big sagebrush) & 0.5 & 20.0 \\
\hline Ambrosia acanthicarpa (bur ragweed) & 0.5 & 20.0 \\
\hline Lactuca serriola $^{\mathrm{a}}$ (prickly lettuce) & 0.3 & 13.3 \\
\hline Hordeum leporinum ${ }^{\mathrm{a}}$ (hare barley) & 0.2 & 6.7 \\
\hline Amsinckia lycopsoides (tarweed fiddleneck) & 0.2 & 6.7 \\
\hline Festuca octoflora (slender sixweeks) & 0.2 & 6.7 \\
\hline Kochia scopari (kochia) & $\mathrm{X}$ & $\mathrm{X}$ \\
\hline Purshia tridentata (antelope bitterbrush) & $\mathrm{X}$ & $X$ \\
\hline Amsinckia lycopsoides (tarweed fiddleneck) & $\mathrm{X}$ & $\mathrm{X}$ \\
\hline Draba verna $^{\mathrm{a}}$ (spring whitlowgrass) & $\mathrm{X}$ & $\mathrm{X}$ \\
\hline Erodium cicutarium ${ }^{\text {a }}$ (storksbill) & $\mathrm{X}$ & $\mathrm{X}$ \\
\hline Chrysothamnus nauseosus (gray rabbitbrush) & $\mathrm{X}$ & $X$ \\
\hline Biotic crust & 0.0 & 0.0 \\
\hline Bare soil & 35.8 & 100.0 \\
\hline Litter & 61.0 & 100.0 \\
\hline Total canopy cover (litter not included) & 50.7 & \\
\hline \multicolumn{3}{|l|}{${ }^{\mathrm{a}}$ Invasive species } \\
\hline Total Invasive \% Cover & 26.2 & \\
\hline Total Native \% Cover & 24.5 & \\
\hline
\end{tabular}




\subsection{AREA SITES}

\subsection{HANFORD GENERATING PLANT}

Energy Northwest Inc. worked on demolition of the 185-N Hanford Generating Plant complex from 2001 through 2004. The remedial action objectives and goals were attained for the sites in accordance with the 100-N Area Ancillary Facilities Action Memorandum (Ecology et al. 1999) and in accordance with the Interim Remedial Action Record of Decision for the 100-NR-1 Operable Unit (Ecology 2000) and Removal Action Work Plan for the Hanford Generating Plant Ancillary Facilities (DOE-RL 1999).

The Hanford Generating Plant was transferred from Energy Northwest Inc. to the Environmental Restoration Contractor in August 2004 and included into the RCCC work scope in August 2006. Revegetation of the area disturbed during the demolition and remediation activities was initiated in early February and continued through mid-March 2006. Prior to seeding, the compacted soils were loosened with a disk. The area was broadcast seeded with a mix of native grass seed that included Sandberg's bluegrass, Indian ricegrass, thickspike wheatgrass, bluebunch wheatgrass, prairie junegrass (Koeleria cristata), and needle-and-thread grass. Triple-16 fertilizer and polyacrylamide (water-retaining crystals) were applied during seeding. The seeded area was mulched with straw and planted with sagebrush seedlings that were grown in 10-in. tubes from seed collected on the Hanford Site (Figure 5).

The planted area was separated into two section for analysis; the eastern half of the area has native fine-grained topsoil that was not removed during the demolition activities, while the western area has rocky cobble backfill material from a nearby borrow pit. Fifth-year monitoring was conducted on both areas on April 21, 2010 (Table 5). Native cover was observed to drop significantly on both portions of the Hanford Generating Plant revegetation from the numbers recorded in 2009. Most of the drop was in canopy cover of Sandberg's bluegrass, which may be attributable to the unusually cool spring experienced this year. Cheatgrass cover and overall non-native cover were also much lower than observed in 2009.

Sagebrush survival at the topsoil site was only $10 \%$, but survival had stabilized and many recruits were observed around shrubs that had bloomed the previous year; $83 \%$ of the shrubs on the topsoil site bloomed in the previous year. Overall shrub survival across two monitoring transects on the cobble area shown $38 \%$ of planted shrubs surviving on the site. Sixty-four percent of the shrubs on the monitoring transects had bloomed in the previous year.

Overall, the revegetation effort on the cobble area was successful. The area is dominated by native species with a low level of invasion by non-natives. Shrub survival is 38\%, but the photo on the next page helps to show that sagebrush has become well established on this site. The topsoil area, however, was less successful. Invasive species canopy cover remains high even after the fifth year, and shrub survival was very low. This area will likely require additional efforts to meet restoration goals. 
Figure 5. Hanford Generating Plant in 2010.
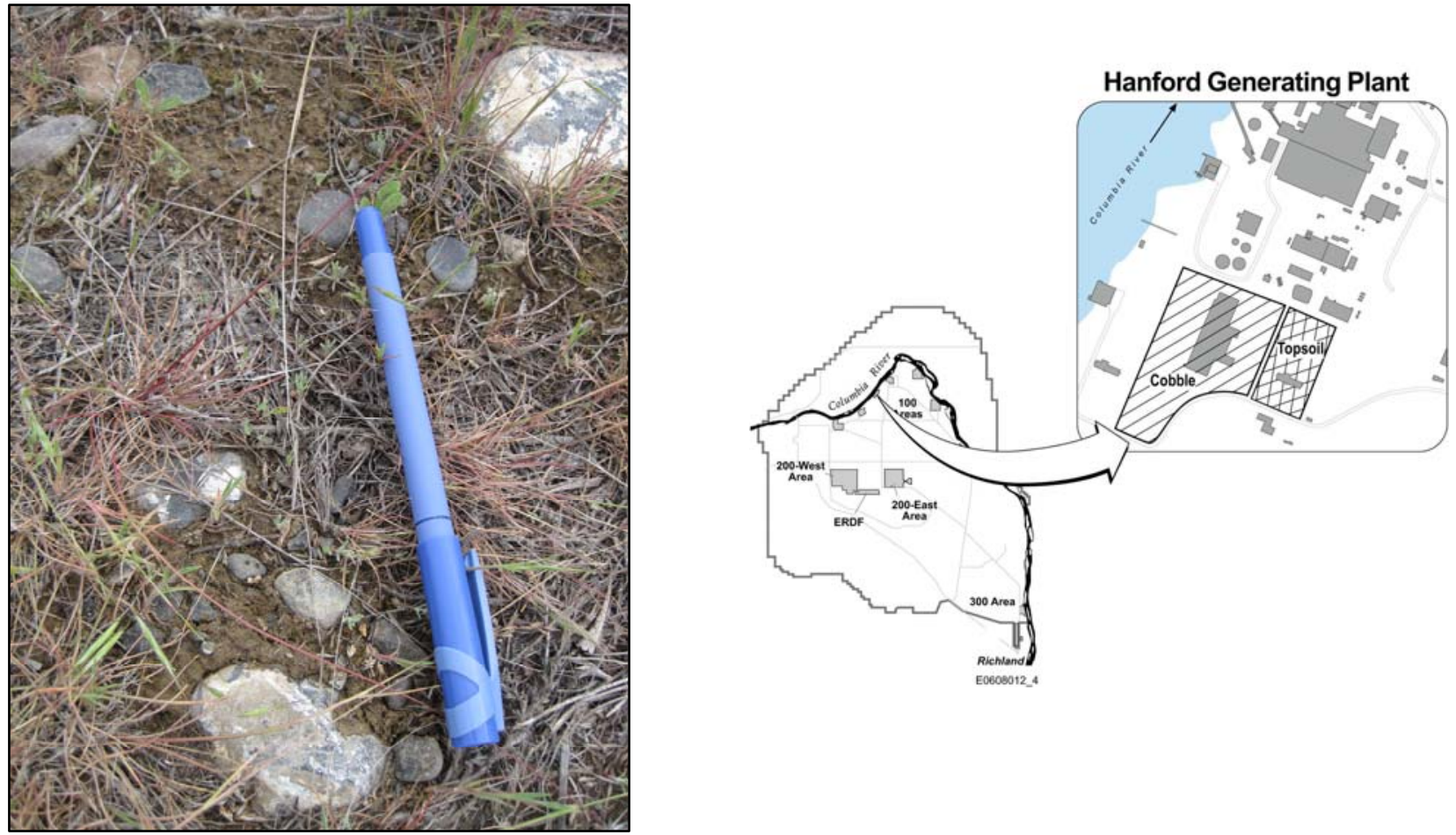

Sagebrush recruits at the Hanford Generating Plant topsoil area.

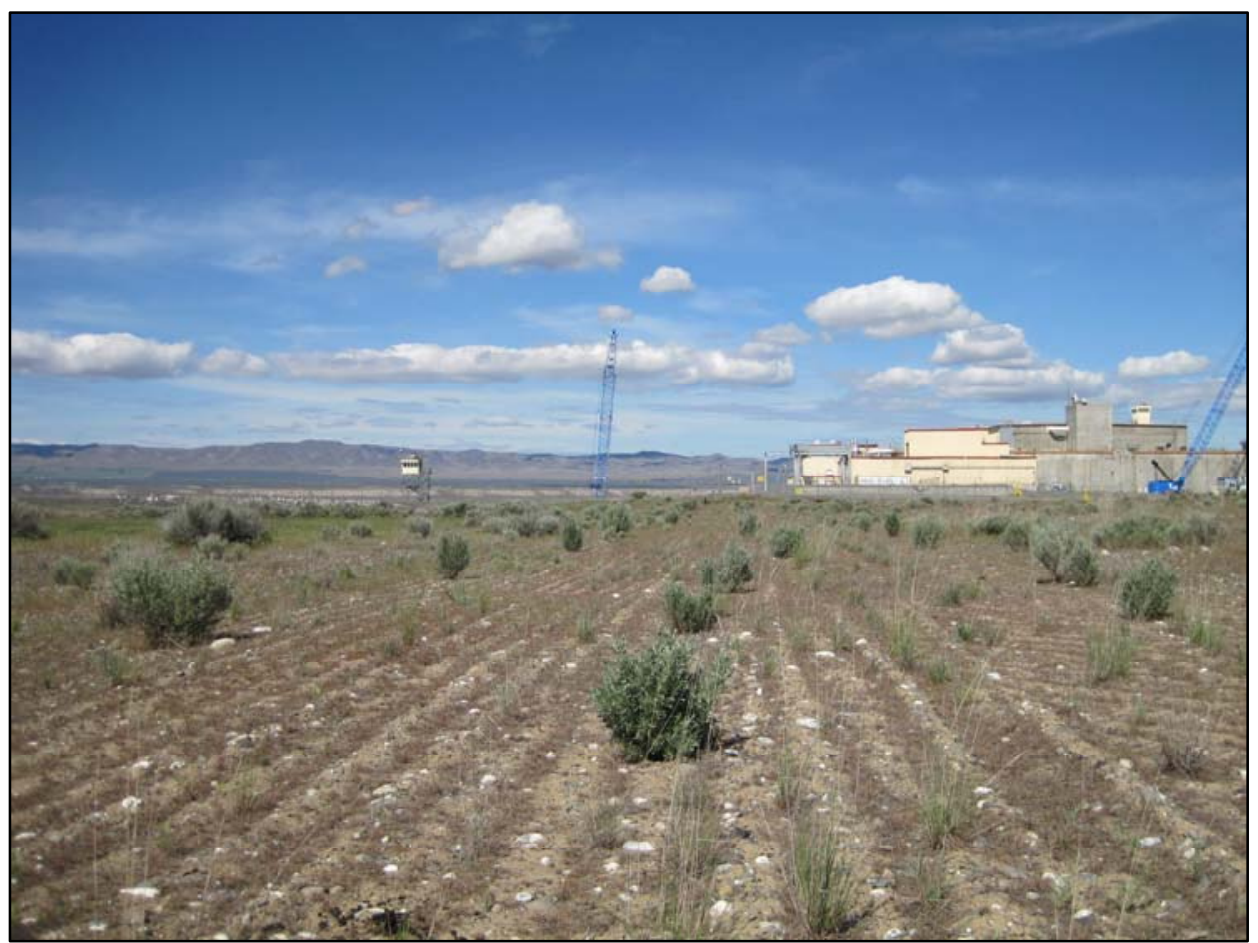

Planted sagebrush and bunchgrasses at the Hanford Generating Plant cobble area. 
Table 5. Percent Canopy Cover and Frequency of Occurrence at Hanford Generating Plant Topsoil in 2010.

\begin{tabular}{|c|c|c|c|c|}
\hline Species & $\begin{array}{c}\text { \% Cover } \\
\text { Topsoil } \\
\end{array}$ & $\begin{array}{c}\text { \% Freq of } \\
\text { Occ Topsoil }\end{array}$ & $\begin{array}{c}\text { \% Cover } \\
\text { Cobble } \\
\end{array}$ & $\begin{array}{l}\text { \% Freq of } \\
\text { Occ Cobble }\end{array}$ \\
\hline Poa sandbergii (Sandberg's bluegrass) & 39.1 & 96.0 & 37.0 & 96.0 \\
\hline Bromus tectorum ${ }^{\text {a }}$ (cheatgrass) & 25.7 & 96.0 & 6.3 & 76.0 \\
\hline Sisymbrium altissimum ${ }^{\mathrm{a}}$ (tumble mustard) & 4.1 & 68.0 & 1.2 & 48.0 \\
\hline Salsola kali (Russian thistle) & 2.6 & 48.0 & 1.5 & 60.0 \\
\hline Holosteum umbellatum ${ }^{\mathrm{a}}$ (jagged chickweed) & 2.5 & 80.0 & 0.2 & 8.0 \\
\hline Chrysothamnus nauseosus (gray rabbitbrush) & 0.4 & 16.0 & 2.0 & 60.0 \\
\hline Agropyron spicatum (bluebunch wheatgrass) & 0.1 & 4.0 & 1.4 & 36.0 \\
\hline Ranunculus testiculatus $^{\mathrm{a}}$ (bur buttercup) & 1.1 & 24.0 & -- & -- \\
\hline Sitanion hystrix (bottlebrush squirreltail) & 0.2 & 8.0 & 1.0 & 20.0 \\
\hline Descurainia pinnata (western tansymustard) & $\mathrm{X}$ & $\mathrm{X}$ & 0.9 & 16.0 \\
\hline Draba verna $^{\mathrm{a}}$ (spring whitlowgrass) & 0.8 & 32.0 & 0.3 & 12.0 \\
\hline Centaurea diffusa $a^{\mathrm{a}}$ (diffuse knapweed) & 0.8 & 32.0 & 0.5 & 20.0 \\
\hline Chorispora tenella (blue mustard) & 0.8 & 32.0 & 0.1 & 4.0 \\
\hline Festuca octoflora (slender sixweeks) & 0.1 & 4.0 & 0.6 & 24.0 \\
\hline Erodium cicutarium $^{\mathrm{a}}$ (storksbill) & 0.1 & 4.0 & 0.4 & 16.0 \\
\hline Epilobium paniculatum (tall willowherb) & $\mathrm{X}$ & $\mathrm{X}$ & 0.3 & 12.0 \\
\hline Amsinckia lycopsoides (tarweed fiddleneck) & 0.3 & 12.0 & -- & -- \\
\hline Achillea millefolium (yarrow) & 0.2 & 8.0 & 0.2 & 8.0 \\
\hline Epilobium paniculatum (tall willowherb) & 0.2 & 8.0 & -- & -- \\
\hline Machaeranthera canescens (hoary aster) & 0.1 & 4.0 & 0.2 & 8.0 \\
\hline Artemisia tridentata (big sagebrush) & 0.2 & 8.0 & 0.1 & 4.0 \\
\hline Microsteris gracilis (pink microsteris) & 0.1 & 4.0 & -- & -- \\
\hline Oryzopsis hymenoides (Indian ricegrass) & 0.1 & 4.0 & $\mathrm{X}$ & $\mathrm{X}$ \\
\hline Poa bulbosa (bulbous bluegrass) & $\mathrm{X}$ & $\mathrm{X}$ & 0.1 & 4.0 \\
\hline Sphaeralcea munroana (Munro's globemallow) & $\mathrm{X}$ & $\mathrm{X}$ & $\mathrm{X}$ & $\mathrm{X}$ \\
\hline Chondrilla juncea $^{\mathrm{a}}$ (rush skeletonweed) & $\mathrm{X}$ & $\mathrm{X}$ & -- & -- \\
\hline Lactuca serriola $^{\mathrm{a}}$ (prickly lettuce) & $\mathrm{X}$ & $\mathrm{X}$ & 0.1 & 4.0 \\
\hline Lepidium perfoliatum ${ }^{\text {a }}$ (clasping pepperweed) & $\mathrm{X}$ & $\mathrm{X}$ & -- & -- \\
\hline Verbascum thapsus ${ }^{\mathrm{a}}$ (common mullein) & -- & -- & $\mathrm{X}$ & $\mathrm{X}$ \\
\hline Agropyron cristatum (crested wheatgrass) & -- & -- & $\mathrm{X}$ & $\mathrm{X}$ \\
\hline Eriogonum niveum (snow buckwheat) & -- & -- & $\mathrm{X}$ & $\mathrm{X}$ \\
\hline Biotic crust & 0.1 & 4.0 & 7.4 & 64.0 \\
\hline Bare soil & 0.2 & 8.0 & 47.9 & 100.0 \\
\hline Litter & 0.2 & 8.0 & 33.0 & 100.0 \\
\hline Total canopy cover (litter not included) & 79.6 & & 54.4 & \\
\hline \multicolumn{5}{|l|}{$\begin{array}{l}\mathrm{a} \text { Invasive species } \\
\mathrm{X}=\text { present but not counted in plot frames }\end{array}$} \\
\hline Total Invasive \% Cover & 38.5 & & 10.7 & \\
\hline Total Native \% Cover & 41.1 & & 43.7 & \\
\hline Change in Native \% Cover from 2009 & -13.1 & & -34.2 & \\
\hline
\end{tabular}




\section{$3.2 \quad 116-\mathrm{N}-1$}

The 116-N-1 Crib and Trench were remediated to remedial action objectives, remedial action goals, and closure performance standards established by the U.S. Environmental Protection Agency and Washington State Department of Ecology in concurrence with the U.S. Department of Energy, Richland Operations Office. The goals and objectives are documented in the 100-NR-1 Interim Remedial Action Record of Decision (Ecology 2000) and Remedial Design Report/Remedial Action Work Plan for the 100-NR-1 Treatment, Storage, and Disposal Units (DOE-RL 2000).

Revegetation activities on the 116-N-1 Crib and Trench were conducted in December 2006. Native grass species were planted along with sagebrush at 1,235 plants/hectare. Fourth-year monitoring was performed at the site in April 2010 (Figure 6). Invasive cover remains much lower than native canopy cover at this site. Both values dropped since the 2009 monitoring, potentially due to the unusually cool spring. Planted native grasses dominate this site, with Sandberg's bluegrass showing 23\% cover (Table 6). Sagebrush frequency was high, at 28\%, while canopy cover of Russian thistle was only 1.1\%. Tubeling survival remains high at this site, at $86 \%$, with $96 \%$ of the shrubs recorded in 2009 still surviving. At this point, sagebrush has become well established at the site, with approximately 15\% of the shrubs blooming during the previous year.

Figure 6. 116-N-1 Waste Site in 2010.

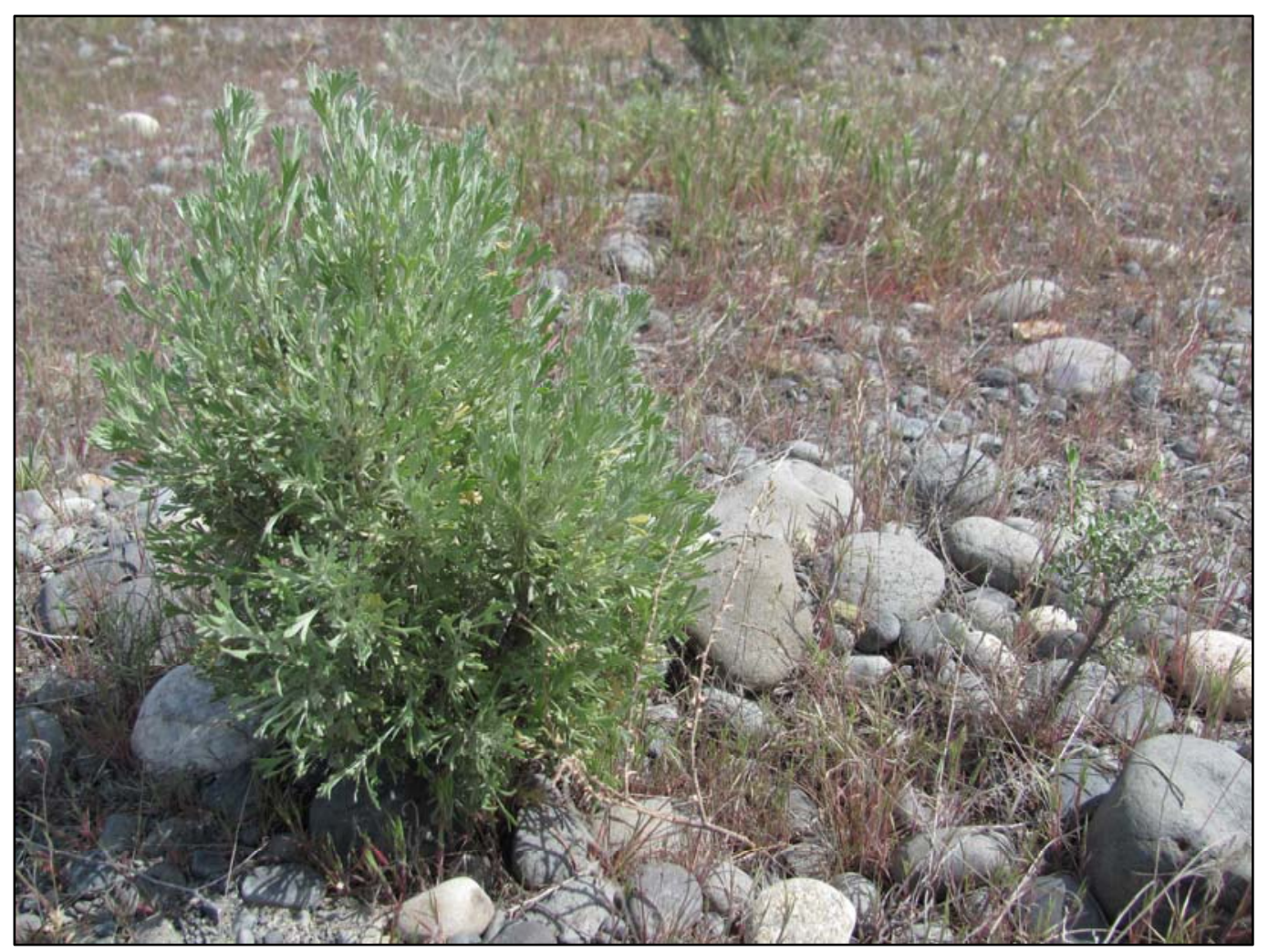

Planted sagebrush and hopsage growing at the 116-N-1 site. 
Table 6. Percent Canopy Cover and Frequency of Occurrence at 116-N-1 in 2010.

\begin{tabular}{|c|c|c|}
\hline Species & \% Cover & $\%$ Freq of Occ \\
\hline Poa sandbergii (Sandberg's bluegrass) & 23.8 & 100.0 \\
\hline Bromus tectorum $^{\mathrm{a}}$ (cheatgrass) & 6.4 & 100.0 \\
\hline Agropyron dasytachyum (thickspike wheatgrass) & 2.4 & 20.0 \\
\hline Artemisia tridentata (big sagebrush) & 1.8 & 16.0 \\
\hline Salsola kali (Russian thistle) & 1.3 & 52.0 \\
\hline Agropyron spicatum (bluebunch wheatgrass) & 1.2 & 48.0 \\
\hline Sisymbrium altissimum ${ }^{\mathrm{a}}$ (tumble mustard) & 1.1 & 44.0 \\
\hline Chrysothamnus nauseosus (gray rabbitbrush) & 0.3 & 12.0 \\
\hline Holosteum umbellatum ${ }^{\mathrm{a}}$ (jagged chickweed) & 0.2 & 8.0 \\
\hline Chaenactis douglasii (hoary falseyarrow) & 0.1 & 4.0 \\
\hline Lactuca serriola ${ }^{\mathrm{a}}$ (prickly lettuce) & 0.1 & 4.0 \\
\hline Melilotus alba ${ }^{\mathrm{a}}$ (sweetclover) & $\mathrm{X}$ & $\mathrm{X}$ \\
\hline Centaurea diffusa $a^{\mathrm{a}}$ (diffuse knapweed) & $\mathrm{X}$ & $\mathrm{X}$ \\
\hline Erigeron filifolius (threadleaf fleabane) & $\mathrm{X}$ & $\mathrm{X}$ \\
\hline Lactuca serriola ${ }^{\mathrm{a}}$ (prickly lettuce) & $\mathrm{X}$ & $\mathrm{X}$ \\
\hline Descurainia pinnata (western tansymustard) & $\mathrm{X}$ & $\mathrm{X}$ \\
\hline Draba verna ${ }^{\mathrm{a}}$ (spring whitlowgrass) & $\mathrm{X}$ & $\mathrm{X}$ \\
\hline Oryzopsis hymenoides (Indian ricegrass) & $\mathrm{X}$ & $\mathrm{X}$ \\
\hline Agastache occidentalis (western horsemint) & $\mathrm{X}$ & $\mathrm{X}$ \\
\hline Amsinckia lycopsoides (tarweed fiddleneck) & $\mathrm{X}$ & $\mathrm{X}$ \\
\hline Chondrilla juncea $^{\mathrm{a}}$ (rush skeletonweed) & $\mathrm{X}$ & $\mathrm{X}$ \\
\hline Tragopogon dubius ${ }^{a}$ (yellow salsify) & $\mathrm{X}$ & $\mathrm{X}$ \\
\hline Grayia spinosa (spiny hopsage) & $\mathrm{X}$ & $\mathrm{X}$ \\
\hline Achillea millefolium (yarrow) & $\mathrm{X}$ & $\mathrm{X}$ \\
\hline Epilobium paniculatum (tall willowherb) & $\mathrm{X}$ & $\mathrm{X}$ \\
\hline Biotic crust & 0.0 & 0.0 \\
\hline Bare soil & 38.9 & 100.0 \\
\hline Litter & 46.5 & 100.0 \\
\hline Total canopy cover (litter not included) & 38.7 & \\
\hline \multicolumn{3}{|l|}{$\begin{array}{l}{ }^{\mathrm{a}} \text { Invasive species } \\
\mathrm{X}=\text { present but not counted in plot frames }\end{array}$} \\
\hline Total Invasive \% Cover & 9.1 & \\
\hline Total Native \% Cover & 29.6 & \\
\hline Change in Native \% Cover from 2009 & -18.9 & \\
\hline
\end{tabular}




\subsection{0-F SITES PLANTED IN 2008}

Areas that were revegetated between December 2007 and February 2008 and that were monitored in 2009 include the 118-F-1, 118-F-2, 182-F, 183-F East Clearwell, 100-F-26, and 118-F-5. These sites were remediated to meet the objectives for interim closure as established in the Remedial Design Report/Remedial Action Work Plan for the 100 Area (RDR/RAWP) (DOE-RL 2005a) and in the Interim Action Record of Decision for the 100-BC-1, 100-BC-2, 100-DR-1, 100-DR-2, 100-FR-1, 100-FR-2, 100-HR-1, 100-HR-2, 100-KR-1, 100-KR-2, 100-IU-2, 100-IU-6, and 200-CW-3 Operable Units, Hanford Site, Benton County, Washington (EPA 1999). These sites were broadcast seeded with a mixture of native grasses including Sandberg's bluegrass, Indian ricegrass, bluebunch wheatgrass, prairie junegrass, bottlebrush squirreltail, and needle-and-thread grass. In addition, $134 \mathrm{~kg} / \mathrm{ha}$ of Triple-16 fertilizer was added to the sites along with $4,480 \mathrm{~kg} / \mathrm{ha}$ of straw mulch that was spread and crimped into the soil surface. Sagebrush plugs were then planted into the seeded areas at 1,200 plants/ha.

\subsubsection{8-F-1}

Third-year monitoring was conducted at the 118-F-1 site in 2010 (Figure 7). Russian thistle remains the dominant species for canopy cover, at $16 \%$, while Sandberg's bluegrass increased to 14\% cover and $100 \%$ occurrence (Table 7 ). Ten native species were observed at the site. Subsequent monitoring is expected to show that as the planted native grasses continue to grow and fill in with recruits, they will begin to outcompete the Russian thistle.

Sagebrush monitoring showed $62 \%$ survival, with $71 \%$ of the shrubs on the site blooming in the previous year. This high survival, combined with a high percentage of blooming shrubs, provides early indication that the sagebrush planting was successful on this portion of the site. In contrast, no shrubs were observed alive on the second transect as of 2009. This was observed to be due to the extremely compacted soils on that portion of the site, which provides an excellent example of the necessity of ripping compacted soils prior to initiating revegetation efforts.

\subsubsection{8-F-2}

Third-year monitoring was performed at the 118-F-2 site in 2010. For the first time, a native species was recorded as the dominant plant on the site, with Sandberg's bluegrass showing 9\% canopy cover and 100\% occurrence within the plot frames (Table 8). Fifteen native species were observed on the site in 2010, up from 11 in 2009. This represents high diversity for a site only in its third year. Relatively low canopy cover on the site may be due to the cool spring, and the well-draining sandy soils present.

Sagebrush monitoring was also counted on this site in 2010. Shrub survival continued to drop from $16.6 \%$ in 2009 to $12.5 \%$ in 2010 . The sagebrush on another portion of the site, which was used for soil staging and has much better soil conditions, appear to be doing very well, although no transect was established on this portion of the site. The low shrub survival will need to be rectified if recruitment is not observed in the next 2 years. 
Figure 7. 118-F-1 and 118-F-2 Waste Sites in 2010.

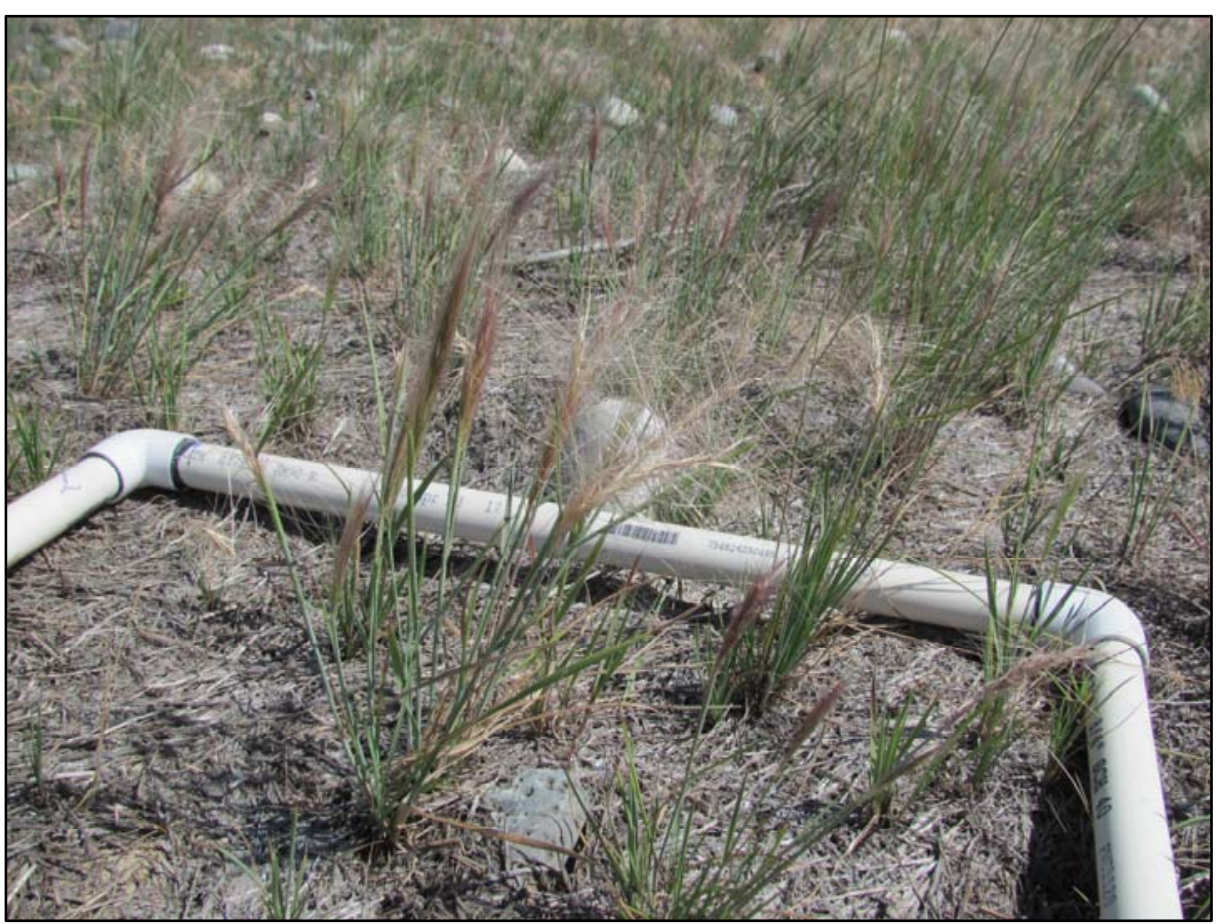

Planted bottlebrush squirreltail in a plot-frame at the 118-F-1 site in 2010.

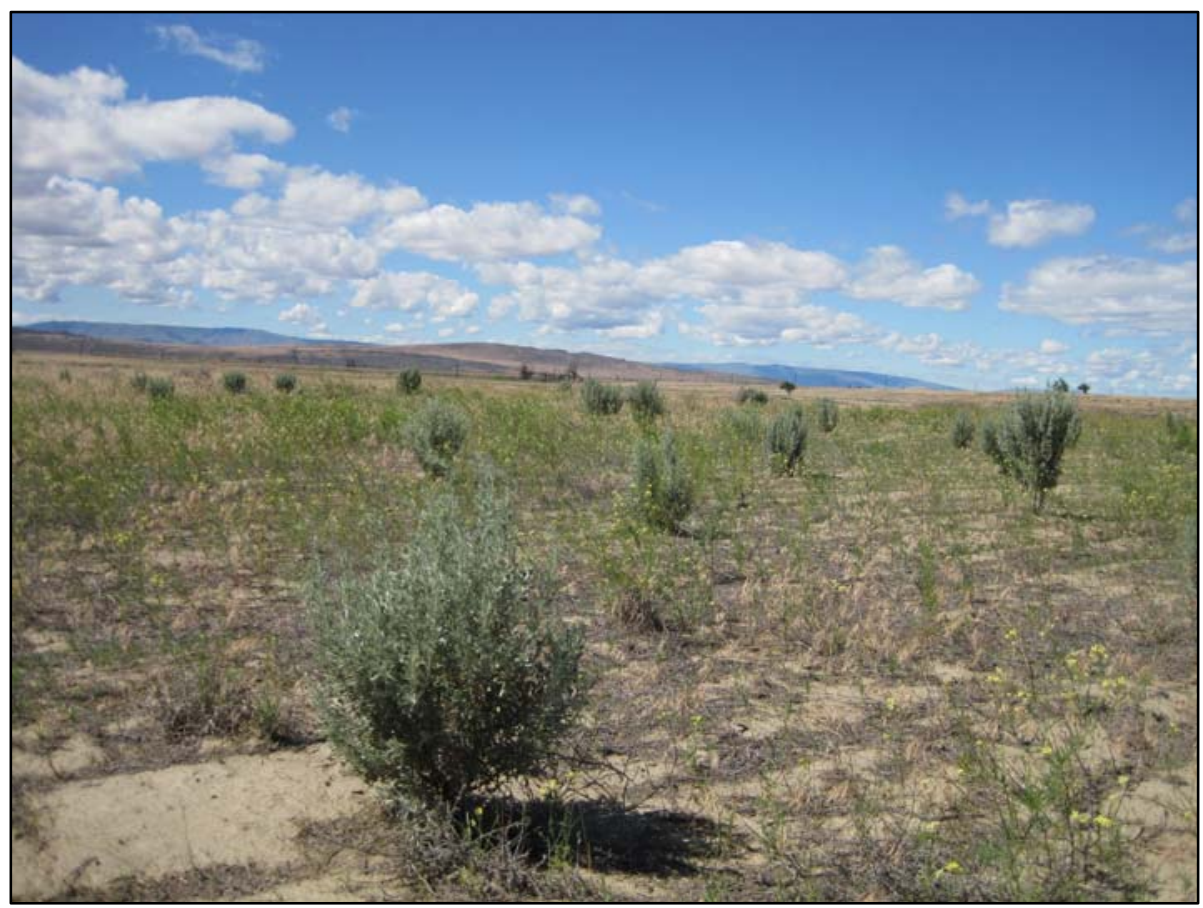

Planted sagebrush at the 118-F-2 soil staging area in 2010. 
WCH-428

Rev. 0

Table 7. Percent Canopy Cover and Frequency of Occurrence at 118-F-1 in 2010.

\begin{tabular}{|c|c|c|}
\hline Species & \% Cover & $\%$ Freq of Occ \\
\hline Salsola kali (Russian thistle) & 19.5 & 92.0 \\
\hline Poa sandbergii (Sandberg's bluegrass) & 14.0 & 100.0 \\
\hline Bromus tectorum ${ }^{\mathrm{a}}$ (cheatgrass) & 5.2 & 52.0 \\
\hline Sisymbrium altissimum ${ }^{\mathrm{a}}$ (tumble mustard) & 1.9 & 36.0 \\
\hline Poa bulbosa ${ }^{\mathrm{a}}$ (bulbous bluegrass) & 1.8 & 16.0 \\
\hline Sitanion hystrix (bottlebrush squirreltail) & 1.6 & 8.0 \\
\hline Agropyron spicatum (bluebunch wheatgrass) & 1.0 & 40.0 \\
\hline Artemisia tridentata (big sagebrush) & 0.6 & 4.0 \\
\hline Lactuca serriola ${ }^{\mathrm{a}}$ (prickly lettuce) & 0.3 & 12.0 \\
\hline Holosteum umbellatum ${ }^{\mathrm{a}}$ (jagged chickweed) & 0.1 & 4.0 \\
\hline Chrysothamnus nauseosus (gray rabbitbrush) & $\mathrm{X}$ & $\mathrm{X}$ \\
\hline Epilobium paniculatum (tall willowherb) & $\mathrm{X}$ & $\mathrm{X}$ \\
\hline Achillea millefolium (yarrow) & $\mathrm{X}$ & $\mathrm{X}$ \\
\hline Descurainia pinnata (western tansymustard) & $\mathrm{X}$ & $\mathrm{X}$ \\
\hline Machaeranthera canescens (hoary aster) & $\mathrm{X}$ & $\mathrm{X}$ \\
\hline Grayia spinosa (spiny hopsage) & $\mathrm{X}$ & $\mathrm{X}$ \\
\hline Tragopogon dubius ${ }^{\text {a }}$ (yellow salsify) & $\mathrm{X}$ & $\mathrm{X}$ \\
\hline Crust & 0.0 & 0.0 \\
\hline Soil & 56.4 & 100.0 \\
\hline Litter & 36.1 & 100.0 \\
\hline Total canopy cover (litter not included) & 46.0 & \\
\hline \multicolumn{3}{|l|}{$\begin{array}{l}{ }^{\mathrm{a}} \text { Invasive species } \\
\mathrm{X}=\text { present but not counted in plot frames }\end{array}$} \\
\hline Total Invasive \% Cover & 28.8 & \\
\hline Total Native \% Cover & 17.2 & \\
\hline Change in Native \% Cover from 2009 & -6.1 & \\
\hline
\end{tabular}


Table 8. Percent Canopy Cover and Frequency of Occurrence at 118-F-2 in 2010.

\begin{tabular}{|c|c|c|}
\hline Species & \% Cover & $\%$ Freq of Occ \\
\hline Poa sandbergii (Sandberg's bluegrass) & 9.3 & 100.0 \\
\hline Salsola kali (Russian thistle) & 4.3 & 92.0 \\
\hline Sitanion hystrix (bottlebrush squirreltail) & 2.2 & 48.0 \\
\hline Bromus tectorum ${ }^{\text {a }}$ (cheatgrass) & 1.9 & 56.0 \\
\hline Oryzopsis hymenoides (Indian ricegrass) & 1.1 & 44.0 \\
\hline Agropyron spicatum (bluebunch wheatgrass) & 1.0 & 40.0 \\
\hline Sisymbrium altissimum ${ }^{\mathrm{a}}$ (tumble mustard) & 0.9 & 16.0 \\
\hline Machaeranthera canescens (hoary aster) & 0.5 & 20.0 \\
\hline Draba verna $^{\mathrm{a}}$ (spring whitlowgrass) & 0.4 & 16.0 \\
\hline Achillea millefolium (yarrow) & 0.4 & 16.0 \\
\hline Chrysothamnus nauseosus (gray rabbitbrush) & 0.4 & 16.0 \\
\hline Poa bulbosa ${ }^{\mathrm{a}}$ (bulbous bluegrass) & 0.3 & 12.0 \\
\hline Descurainia pinnata (western tansymustard) & 0.2 & 8.0 \\
\hline Agropyron dasytachyum (thickspike wheatgrass) & 0.1 & 4.0 \\
\hline Lepidium perfoliatum ${ }^{\mathrm{a}}$ (clasping pepperweed) & 0.1 & 4.0 \\
\hline Festuca octoflora (slender sixweeks) & 0.1 & 4.0 \\
\hline Centaurea diffusa $a^{\text {a }}$ (diffuse knapweed) & 0.1 & 4.0 \\
\hline Cryptantha fendleri (Fendler's cryptantha) & 0.1 & 4.0 \\
\hline Holosteum umbellatum ${ }^{\mathrm{a}}$ (jagged chickweed) & 0.1 & 4.0 \\
\hline Ambrosia acanthicarpa (bur ragweed) & $\mathrm{X}$ & $\mathrm{X}$ \\
\hline Artemisia tridentata (big sagebrush) & $\mathrm{X}$ & $\mathrm{X}$ \\
\hline Lactuca serriola ${ }^{\mathrm{a}}$ (prickly lettuce) & $\mathrm{X}$ & $\mathrm{X}$ \\
\hline Grayia spinosa (spiny hopsage) & $\mathrm{X}$ & $\mathrm{X}$ \\
\hline Tragopogon dubius ${ }^{\text {a }}$ (yellow salsify) & $\mathrm{X}$ & $\mathrm{X}$ \\
\hline Poa bulbosa ${ }^{\mathrm{a}}$ (bulbous bluegrass) & $\mathrm{X}$ & $\mathrm{X}$ \\
\hline Eriogonum vimineum (broom buckwheat) & $\mathrm{X}$ & $\mathrm{X}$ \\
\hline Amsinckia lycopsoides (tarweed fiddleneck) & $\mathrm{X}$ & $\mathrm{X}$ \\
\hline Vicia cracca $^{\mathrm{a}}$ (bird vetch) & $\mathrm{X}$ & $\mathrm{X}$ \\
\hline Conyza canadensis ${ }^{\mathrm{a}}$ (mare's tail) & $\mathrm{X}$ & $\mathrm{X}$ \\
\hline Cryptantha circumscissa (matted cryptantha) & $\mathrm{X}$ & $\mathrm{X}$ \\
\hline Crust & 0.0 & 0.0 \\
\hline Soil & 55.0 & 100.0 \\
\hline Litter & 32.5 & 100.0 \\
\hline
\end{tabular}

Total canopy cover (litter not included)

23.5

a Invasive species

$\mathrm{X}=$ present but not counted in plot frames

Total Invasive \% Cover

Total Native \% Cover 


\subsubsection{2-F}

This site was divided into a north and south area, to distinguish between the backfilled northern plot where the soil is mostly coarse river cobble and the more fine-grained soil on the southern plot. The south plot was used as a staging area and had been invaded by non-native species prior to revegetation, while the north plot lacked vegetation.

Third-year monitoring was performed at the 182-F site on June 7, 2010 (Figure 8). The dominant species with respect to canopy cover at both portions of the site was cheatgrass (Table 9). However, canopy cover had reduced significantly since the 2009 monitoring. Cover of Russian thistle remained low at both sites, and Sandberg's bluegrass and bottlebrush squirreltail were the dominant native grasses. These sites are very diverse, likely due to the presence of native topsoil on the south area. There were 19 native species recorded across the two sites, along with 15 non-native species. Overall, native cover at the north area was only 8\%, compared to $20 \%$ at the south area. This is likely due to the coarse cobble ground surface in the backfilled north area. Consequently, the north area also supports a low canopy of natives (14\%) compared to the south area that is dominated by non-natives (53\%). This site provides a good side-by-side comparison of areas that were revegetated at the same time; however, results are clouded by the presence of weedy species at the start of revegetation at the south site. This site will continue to provide an interesting comparison between revegetations with cobble versus fine-grained soil substrates. 
Figure 8. 182-F North and South Areas in 2010.

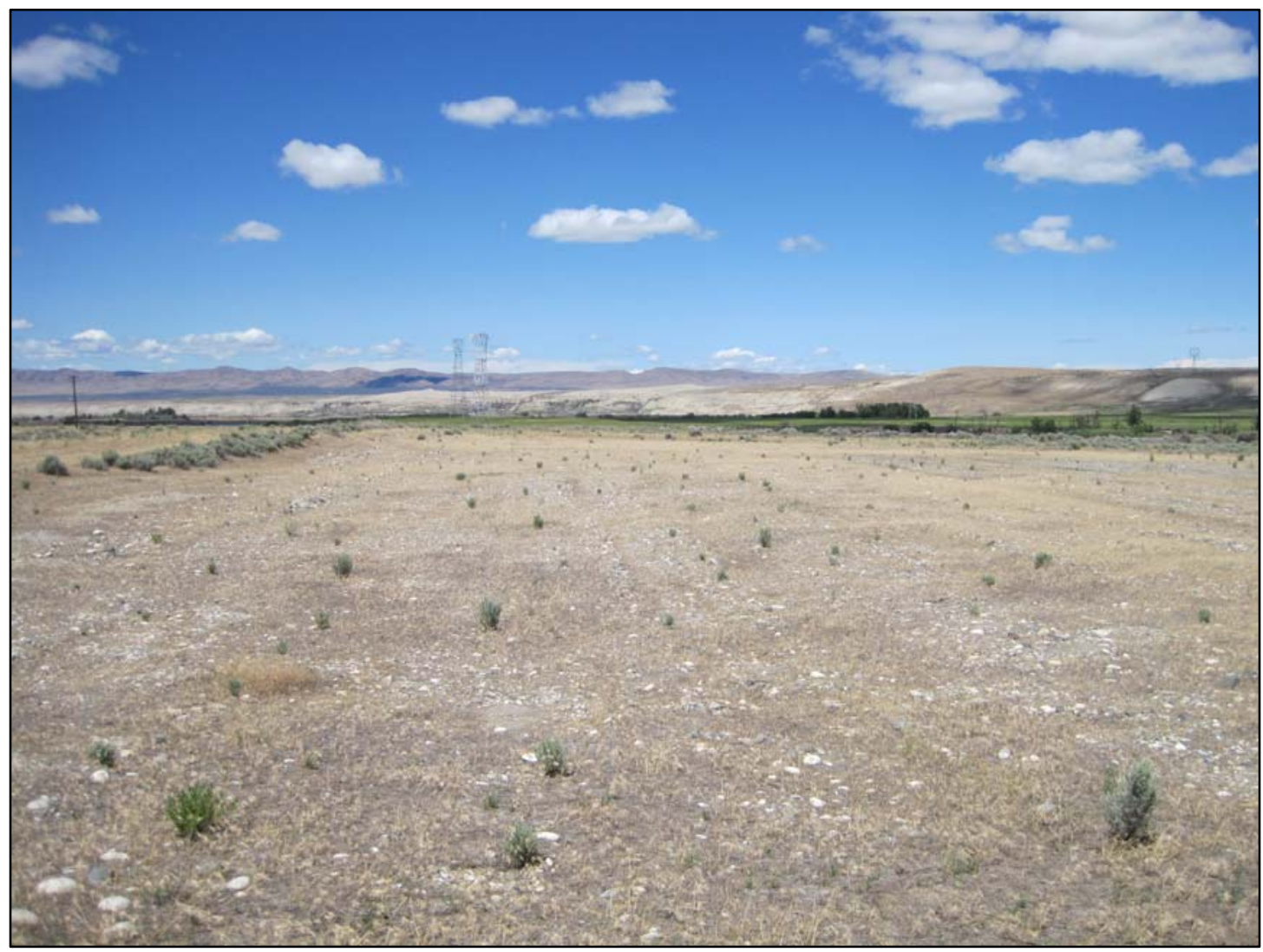

North area showing planted sagebrush and otherwise minimal ground cover.

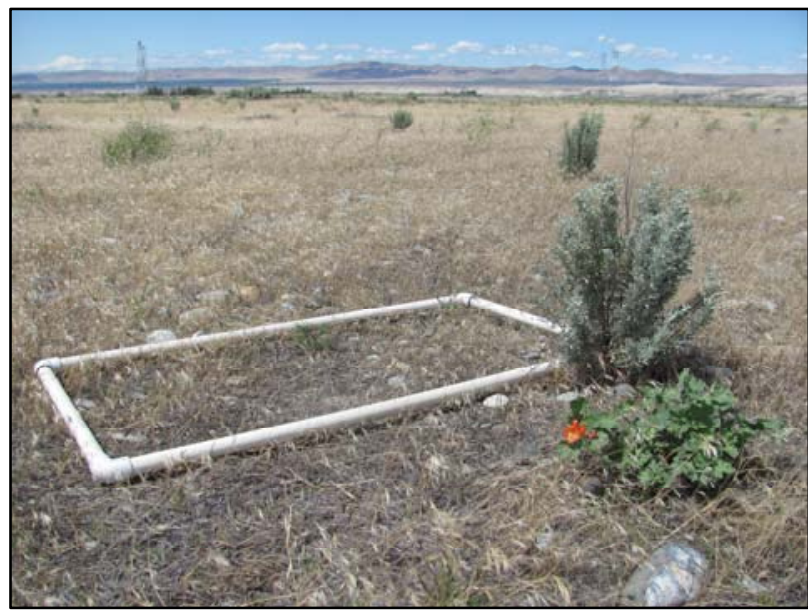

South area showing planted sagebrush and volunteer globemallow.

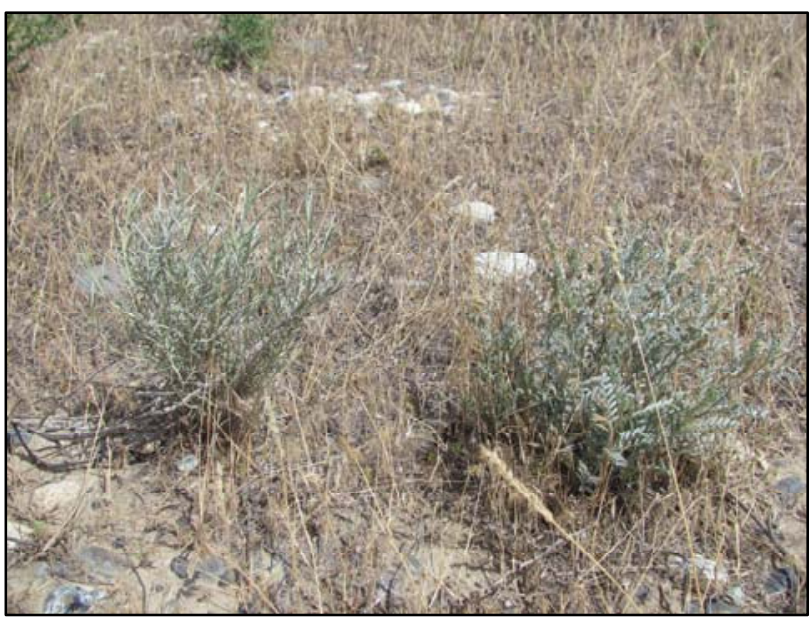

South area showing volunteer gray rabbitbrush and buckwheat milkvetch. 
Table 9. Percent Canopy Cover and Frequency of Occurrence at 182-F in 2010.

\begin{tabular}{|c|c|c|c|c|}
\hline Species & $\begin{array}{l}\text { \% Cover } \\
\text { North }\end{array}$ & $\begin{array}{c}\text { \% Cover } \\
\text { South } \\
\end{array}$ & $\begin{array}{c}\text { \% Freq of Occ } \\
\text { North }\end{array}$ & $\begin{array}{c}\text { \% Freq of Occ } \\
\text { South }\end{array}$ \\
\hline Bromus tectorum ${ }^{\text {a }}$ (cheatgrass) & 8.8 & 44.2 & 93.3 & 100.0 \\
\hline Poa sandbergii (Sandberg's bluegrass) & 4.8 & 14.5 & 100.0 & 84.0 \\
\hline Salsola kali $^{\mathrm{a}}$ (Russian thistle) & 1.3 & 2.9 & 53.3 & 96.0 \\
\hline Sitanion hystrix (bottlebrush squirreltail) & 1.5 & 2.8 & 60.0 & 36.0 \\
\hline Poa bulbosa ${ }^{\mathrm{a}}$ (bulbous bluegrass) & 0.3 & 2.7 & 13.3 & 32.0 \\
\hline Sisymbrium altissimum ${ }^{\mathrm{a}}$ (tumble mustard) & 2.2 & 0.9 & 20.0 & 36.0 \\
\hline Sporobolus cryptandrus (sanddrop seed) & -- & 1.5 & -- & 20.0 \\
\hline Centaurea diffusa ${ }^{\mathrm{a}}$ (diffuse knapweed) & 0.5 & 1.4 & 20.0 & 16.0 \\
\hline Erodium cicutarium ${ }^{\mathrm{a}}$ (storksbill) & 0.3 & 1.2 & 13.3 & 28.0 \\
\hline Agropyron spicatum (bluebunch wheatgrass) & 0.8 & 0.6 & 33.3 & 24.0 \\
\hline Festuca octoflora (slender sixweeks) & 0.5 & 0.5 & 20.0 & 20.0 \\
\hline Draba verna ${ }^{\text {a }}$ (spring whitlowgrass) & 0.3 & 0.3 & 13.3 & 12.0 \\
\hline Chrysothamnus nauseosus (gray rabbitbrush) & $\mathrm{X}$ & 0.2 & $\mathrm{X}$ & 8.0 \\
\hline Epilobium paniculatum (tall willowherb) & 0.2 & -- & 6.7 & -- \\
\hline Artemisia campestris (Pacific sage) & 0.2 & $\mathrm{X}$ & 6.7 & $\mathrm{X}$ \\
\hline Holosteum umbellatum a (jagged chickweed) & -- & 0.1 & -- & 4.0 \\
\hline Achillea millefolium (yarrow) & $\mathrm{X}$ & 0.1 & $\mathrm{X}$ & 4.0 \\
\hline Artemisia tridentata (big sagebrush) & $\mathrm{X}$ & 0.1 & $\mathrm{X}$ & 4.0 \\
\hline Oryzopsis hymenoides (Indian ricegrass) & -- & 0.1 & -- & 4.0 \\
\hline Tragopogon dubius ${ }^{\mathrm{a}}$ (yellow salsify) & $\mathrm{X}$ & 0.1 & $\mathrm{X}$ & 4.0 \\
\hline Ambrosia acanthicarpa (bur ragweed) & -- & 0.1 & -- & 4.0 \\
\hline Astragalus caricinus (buckwheat milkvetch) & -- & $\mathrm{X}$ & -- & $\mathrm{X}$ \\
\hline Astragalus sclerocarpus (stalked pod milkvetch) & -- & $\mathrm{X}$ & -- & $\mathrm{X}$ \\
\hline Astragalus succumbens (crouching milkvetch) & $\mathrm{X}$ & -- & $\mathrm{X}$ & -- \\
\hline Chaenactis douglasii (hoary falseyarrow) & -- & $\mathrm{X}$ & -- & $\mathrm{X}$ \\
\hline Descurainia pinnata (western tansymustard) & -- & $\mathrm{X}$ & -- & $\mathrm{X}$ \\
\hline Conyza canadensis $^{a}$ (mare's tail) & -- & $\mathrm{X}$ & -- & $\mathrm{X}$ \\
\hline Lactuca serriola $^{\mathrm{a}}$ (prickly lettuce) & $\mathrm{X}$ & $\mathrm{X}$ & $\mathrm{X}$ & $\mathrm{X}$ \\
\hline Sphaeralcea munroana (Munro's globemallow) & $\mathrm{X}$ & $\mathrm{X}$ & $\mathrm{X}$ & $\mathrm{X}$ \\
\hline Verbena bracteata (big-bract verbena) & $\mathrm{X}$ & $\mathrm{X}$ & $\mathrm{X}$ & $\mathrm{X}$ \\
\hline Vicia cracca $^{\mathrm{a}}$ (bird vetch) & -- & $\mathrm{X}$ & -- & $\mathrm{X}$ \\
\hline Sporobolus cryptandrus (sand dropseed) & $\mathrm{X}$ & -- & $\mathrm{X}$ & -- \\
\hline Lepidium perfoliatum ${ }^{\mathrm{a}}$ (clasping pepperweed) & $\mathrm{X}$ & -- & $\mathrm{X}$ & -- \\
\hline Crust & 0.0 & 1.1 & 0.0 & 24.0 \\
\hline Soil & 24.5 & 16.8 & 93.3 & 100.0 \\
\hline Litter & 57.7 & 72.6 & 100.0 & 100.0 \\
\hline Total canopy cover (litter not included) & 22.0 & 74.3 & & \\
\hline \multicolumn{5}{|l|}{ a Invasive species } \\
\hline Total Invasive \% Cover & 14.0 & 53.8 & & \\
\hline Total Native \% Cover & 8.0 & 20.5 & & \\
\hline Change in Native \% Cover from 2009 & -43.7 & -9.4 & & \\
\hline
\end{tabular}




\subsubsection{6-F-2 (183-F) East Clearwell}

The 126-F-2 (183-F) East Clearwell revegetation was monitored for the third year on June 7, 2010. Monitoring showed a significant decrease in overall canopy cover, from 87\% in 2009 down to only 20\% in 2010 (Table 10). Most of this reduction was due to lower recorded cover for Sandberg's bluegrass, Russian thistle, bluebunch wheatgrass, and cheatgrass. Cheatgrass was the dominant species with respect to canopy cover, but still only showed $5 \%$ cover. The dominant native species was bottlebrush squirreltail at 4\% cover, followed by Sandberg's bluegrass at 3\%. Continued monitoring will show if canopy cover remains low for all species due to the cobble substrate, or if bunchgrasses will begin to increase in canopy cover.

Due to the relatively small size of this revegetation, no sagebrush transect was established on the site. However, sagebrush survival appears to be extremely high at the site. Planted tubelings are already blooming, which is relatively uncommon for a site that is this young. Sagebrush seedlings were observed for the first time on this site in 2010 (Figure 9). This, along with the observed high survival rates, is indicative of successful reintroduction of sagebrush to this site.

Table 10. Percent Canopy Cover and Frequency of Occurrence at 126-F-2 in 2010.

\begin{tabular}{|c|c|c|}
\hline Species & \% Cover & $\%$ Freq of Occ \\
\hline Bromus tectorum $^{\mathrm{a}}$ (cheatgrass) & 4.7 & 86.7 \\
\hline Sitanion hystrix (bottlebrush squirreltail) & 3.8 & 86.7 \\
\hline Poa sandbergii (Sandberg's bluegrass) & 3.0 & 86.7 \\
\hline Salsola kali (Russian thistle) & 2.3 & 93.3 \\
\hline Agropyron spicatum (bluebunch wheatgrass) & 1.5 & 60.0 \\
\hline Sisymbrium altissimum ${ }^{\mathrm{a}}$ (tumble mustard) & 1.0 & 40.0 \\
\hline Chrysothamnus nauseosus (gray rabbitbrush) & 0.8 & 33.3 \\
\hline Oryzopsis hymenoides (Indian ricegrass) & 0.8 & 33.3 \\
\hline Artemisia tridentata (big sagebrush) & 0.5 & 20.0 \\
\hline Poa bulbosa ${ }^{\mathrm{a}}$ (bulbous bluegrass) & 0.3 & 13.3 \\
\hline Machaeranthera canescens (hoary aster) & 0.2 & 6.7 \\
\hline Ambrosia acanthicarpa (bur ragweed) & 0.2 & 6.7 \\
\hline Plantago patagonica (Indian wheat) & 0.2 & 6.7 \\
\hline Epilobium paniculatum (tall willowherb) & 0.2 & 6.7 \\
\hline Festuca octoflora (slender sixweeks) & 0.2 & 6.7 \\
\hline Achillea millefolium (yarrow) & 0.2 & 6.7 \\
\hline Centaurea diffusa ${ }^{\text {a }}$ (diffuse knapweed) & 0.2 & 6.7 \\
\hline Astragalus succumbens (crouching milkvetch) & $\mathrm{X}$ & $\mathrm{X}$ \\
\hline Erodium cicutarium $^{\text {a }}$ (storksbill) & $\mathrm{X}$ & $\mathrm{X}$ \\
\hline Grayia spinosa (spiny hopsage) & $\mathrm{X}$ & $\mathrm{X}$ \\
\hline Lactuca serriola ${ }^{\mathrm{a}}$ (prickly lettuce) & $\mathrm{X}$ & $\mathrm{X}$ \\
\hline Biotic crust & 0.0 & 0.0 \\
\hline Bare soil & 28.7 & 100.0 \\
\hline Litter & 50.7 & 100.0 \\
\hline Total canopy cover (litter not included) & 20.0 & \\
\hline \multicolumn{3}{|l|}{$\begin{array}{l}{ }^{\mathrm{a}} \text { Invasive species } \\
\mathrm{X}=\text { present but not counted in plot frames }\end{array}$} \\
\hline Total Invasive \% Cover & 8.5 & \\
\hline Total Native \% Cover & 11.5 & \\
\hline Change in Native \% Cover from 2008 & -43.5 & \\
\hline
\end{tabular}


Figure 9. 126-F-2 (183-F) Clearwell in 2010.

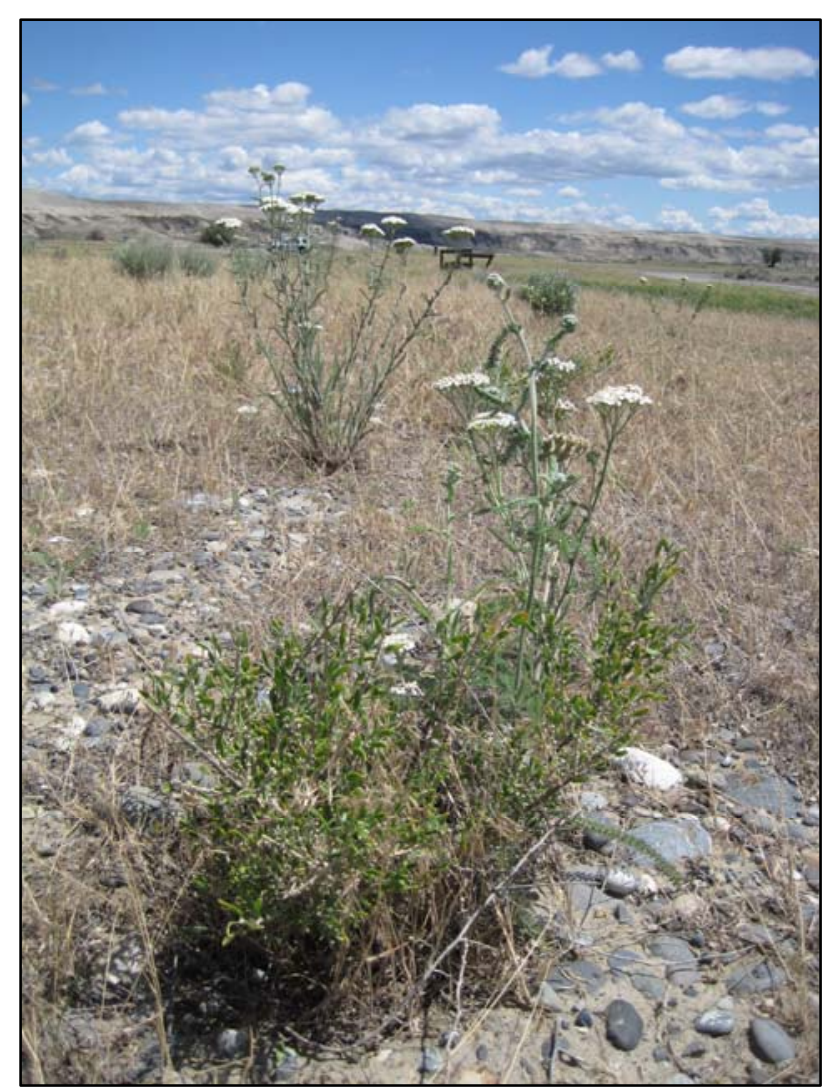

Planted spiny hopsage and volunteer common yarrow at 126-F-2 in 2010.

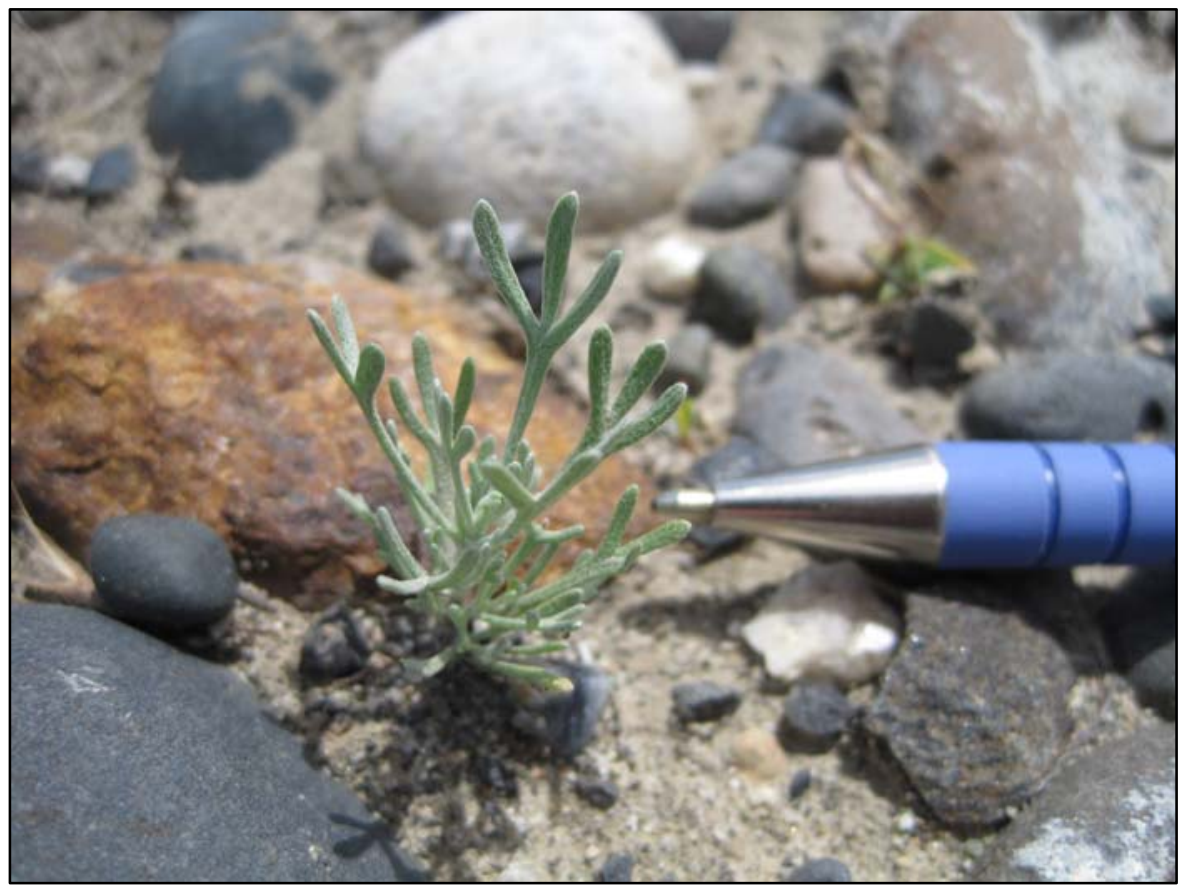

Sagebrush recruit observed at the 126-F-2 revegetation in 2010. 


\subsubsection{0-F-26 Pipelines}

Third-year monitoring was performed at the 100-F-26 site on June 7, 2010 (Figure 10). Monitoring showed a significant reduction in both native and non-native canopy cover. Nonnative canopy cover reduced from 82\% in 2009 to only 39\% in 2010 (Table 11). Native canopy cover reduced from 54\% in 2009 to only 24\% in 2010. Reduced canopy cover is likely due to the cool spring experienced during 2010. Continued monitoring at this site is expected to show the planted bunchgrasses that have become established on the site, Sandberg's bluegrass and bottlebrush squirreltail, becoming more dominant and beginning to outcompete the non-native species. No sagebrush monitoring transect was established on the site. Sagebrush have become established; however, some areas show a relatively thin stand, likely due to the compacted soils present. No shrubs were observed blooming on the site, but as the existing planted shrubs mature and begin to produce seed, they will help to fill in areas currently lacking shrubs on the site.

Figure 10. 100-F-26 Waste Site in 2010.

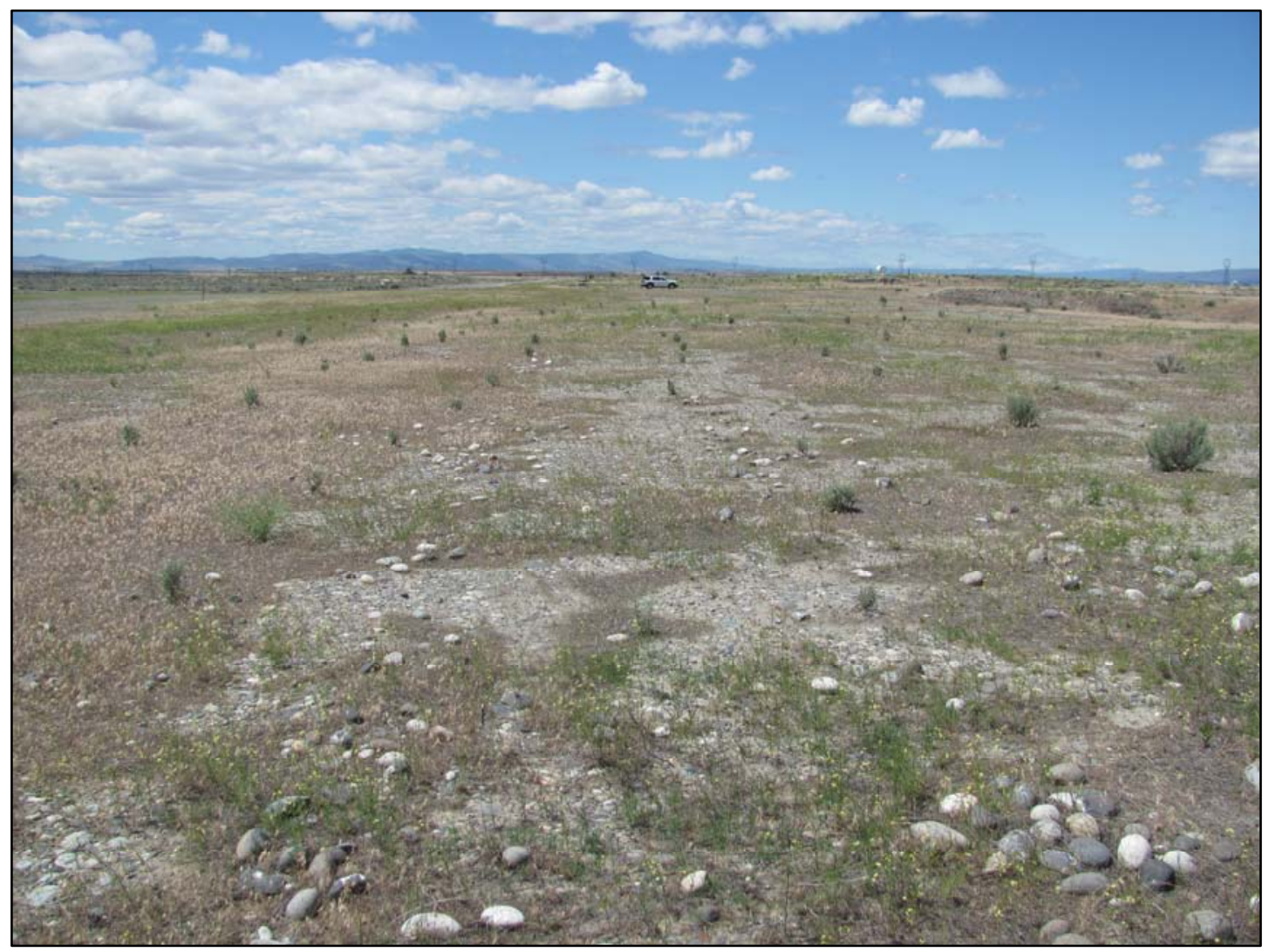

Showing planted sagebrush tubelings at the 100-F-26 site in 2010. 
WCH-428

Rev. 0

Table 11. Percent Canopy Cover and Frequency of Occurrence at 100-F-26 in 2010.

\begin{tabular}{|c|c|c|}
\hline Species & \% Cover & $\%$ Freq of Occ \\
\hline Bromus tectorum ${ }^{\text {a }}$ (cheatgrass) & 24.5 & 100.0 \\
\hline Poa sandbergii (Sandberg's bluegrass) & 20.7 & 93.3 \\
\hline Salsola kali ${ }^{\mathrm{a}}$ (Russian thistle) & 8.3 & 100.0 \\
\hline Sisymbrium altissimum ${ }^{\mathrm{a}}$ (tumble mustard) & 5.3 & 80.0 \\
\hline Sitanion hystrix (bottlebrush squirreltail) & 1.3 & 20.0 \\
\hline Agropyron spicatum (bluebunch wheatgrass) & 1.0 & 40.0 \\
\hline Chrysothamnus nauseosus (gray rabbitbrush) & 0.5 & 20.0 \\
\hline Centaurea diffusa ${ }^{\mathrm{a}}$ (diffuse knapweed) & 0.3 & 13.3 \\
\hline Erodium cicutarium $^{\mathrm{a}}$ (storksbill) & 0.2 & 6.7 \\
\hline Achillea millefolium (yarrow) & 0.2 & 6.7 \\
\hline Artemisia tridentata (big sagebrush) & 0.2 & 6.7 \\
\hline Lactuca serriola ${ }^{a}$ (prickly lettuce) & 0.2 & 6.7 \\
\hline Festuca octoflora (slender sixweeks) & 0.2 & 6.7 \\
\hline Amsinckia lycopsoides (tarweed fiddleneck) & $\mathrm{X}$ & $\mathrm{X}$ \\
\hline Tragopogon dubius ${ }^{\mathrm{a}}$ (yellow salsify) & $\mathrm{X}$ & $\mathrm{X}$ \\
\hline Ambrosia acanthicarpa (bur ragweed) & $\mathrm{X}$ & $\mathrm{X}$ \\
\hline Crust & 0.0 & 0.0 \\
\hline Soil & 42.8 & 100.0 \\
\hline Litter & 50.0 & 100.0 \\
\hline Total canopy cover (litter not included) & 62.8 & \\
\hline \multicolumn{3}{|l|}{$\begin{array}{l}{ }^{\mathrm{a}} \text { Invasive species } \\
\mathrm{X}=\text { present but not counted in plot frames }\end{array}$} \\
\hline Total Invasive \% Cover & 38.8 & \\
\hline Total Native \% Cover & 24.0 & \\
\hline Change in Native \% Cover from 2008 & -30.5 & \\
\hline
\end{tabular}




\subsubsection{8-F-5 Burial Ground}

The 118-F-5 site was separated into two monitoring areas, the burial ground and the soil staging area, so that a comparison can be made between the contrasting soil types at the two areas. The burial ground was backfilled with coarse cobble from a local borrow area, while the soil staging area's substrate is native topsoil. The same revegetation effort was performed at both sites.

Third-year monitoring was conducted at the 118-F-5 site on May 19, 2010. Both areas showed an extreme drop in canopy cover of both cheatgrass and Russian thistle (Table 12). The canopy cover of non-native species dropped from $116 \%$ at the soil staging area in 2009 to only 56\% in 2010. Canopy cover for non-native species dropped from $69 \%$ to $30 \%$ at the burial ground. This site showed very low native canopy cover in 2009, but monitoring in 2010 showed an increase in cover to $9 \%$ at both sites. Both areas continue to be dominated by non-native species, especially cheatgrass. The burial ground showed $22 \%$ cover of cheatgrass, while $49 \%$ cover was recorded at the soil staging area. If the bunchgrasses at these sites do not begin to compete with the cheatgrass, additional effort may be required for these sites to meet restoration goals.

Shrub survival was monitored at one transect on the soil staging area and one transect on the burial ground. Sagebrush survival was $19.5 \%$ on the staging area and $27.6 \%$ on the burial ground. In addition, 11 spiny hopsage plants were recorded on the soil staging area monitoring transect in 2008. In 2009 and 2010 only one of those hopsage plants remained alive.

Table 12. Percent Canopy Cover and Frequency of Occurrence at 118-F-5 in 2010. (2 Pages)

\begin{tabular}{|c|c|c|c|c|}
\hline Species & $\begin{array}{c}\text { \% Cover } \\
\text { BG }\end{array}$ & $\begin{array}{c}\text { \% Cover } \\
\text { SSA }\end{array}$ & $\begin{array}{c}\text { \% Freq of } \\
\text { Occ BG }\end{array}$ & $\begin{array}{c}\% \text { Freq of } \\
\text { Occ SSA }\end{array}$ \\
\hline Bromus tectorum ${ }^{\mathrm{a}}$ (cheatgrass) & 22.2 & 49.3 & 100 & 93.3 \\
\hline Salsola kali ${ }^{\mathrm{a}}$ (Russian thistle) & 5.7 & 3.6 & 100 & 66.7 \\
\hline Poa sandbergii (Sandberg's bluegrass) & 3.8 & 2.9 & 87 & 73.3 \\
\hline Oryzopsis hymenoides (Indian ricegrass) & 2.8 & 0.9 & 80 & 33.3 \\
\hline Agropyron spicatum (bluebunch wheatgrass) & 1.8 & 0.5 & 40 & 20.0 \\
\hline Amsinckia lycopsoides (tarweed fiddleneck) & $\mathrm{X}$ & 1.4 & $\mathrm{X}$ & 53.3 \\
\hline Sisymbrium altissimum ${ }^{\text {a }}$ (tumble mustard) & 1.0 & 1.4 & 40 & 53.3 \\
\hline Holosteum umbellatum ${ }^{\mathrm{a}}$ (jagged chickweed) & -- & 1.3 & -- & 46.7 \\
\hline Microsteris gracilis (pink microsteris) & -- & 0.7 & -- & 26.7 \\
\hline Stipa comata (needle-and-thread grass) & -- & 0.5 & -- & 20.0 \\
\hline Poa bulbosa ${ }^{\mathrm{a}}$ (bulbous bluegrass) & 0.5 & $X$ & 20 & $\mathrm{X}$ \\
\hline Achillea millefolium (yarrow) & $\mathrm{X}$ & 0.5 & $\mathrm{X}$ & 20.0 \\
\hline Draba verna ${ }^{\mathrm{a}}$ (spring whitlowgrass) & 0.3 & 0.5 & 13 & 20.0 \\
\hline Ambrosia acanthicarpa (bur ragweed) & -- & 0.4 & -- & 13.3 \\
\hline Artemisia tridentata (big sagebrush) & 0.2 & 0.2 & 7 & 6.7 \\
\hline Machaeranthera canescens (hoary aster) & 0.2 & 0.2 & 7 & 6.7 \\
\hline Sitanion hystrix (bottlebrush squirreltail) & 0.2 & -- & 7 & -- \\
\hline
\end{tabular}


Table 12. Percent Canopy Cover and Frequency of Occurrence at 118-F-5 in 2010. (2 Pages)

\begin{tabular}{|c|c|c|c|c|}
\hline Species & $\begin{array}{c}\text { \% Cover } \\
\text { BG } \\
\end{array}$ & $\begin{array}{c}\text { \% Cover } \\
\text { SSA } \\
\end{array}$ & $\begin{array}{l}\text { \% Freq of } \\
\text { Occ BG }\end{array}$ & $\begin{array}{l}\text { \% Freq of } \\
\text { Occ SSA }\end{array}$ \\
\hline Chrysothamnus nauseosus (gray rabbitbrush) & $\mathrm{X}$ & 0.2 & $\mathrm{X}$ & 6.7 \\
\hline Plantago patagonica (Indian wheat) & $\mathrm{X}$ & $\mathrm{X}$ & $\mathrm{X}$ & $\mathrm{X}$ \\
\hline Agoseris heterophylla (mountain dandelion) & $\mathrm{X}$ & -- & $\mathrm{X}$ & -- \\
\hline Tragopogon dubius ${ }^{\mathrm{a}}$ (yellow salsify) & $\mathrm{X}$ & -- & $\mathrm{X}$ & -- \\
\hline Sporobolus cryptandrus (sanddrop seed) & -- & $\mathrm{X}$ & -- & $\mathrm{X}$ \\
\hline Grayia spinosa (spiny hopsage) & -- & $\mathrm{X}$ & -- & $\mathrm{X}$ \\
\hline Agoseris heterophylla (mountain dandelion) & -- & $\mathrm{X}$ & -- & $\mathrm{X}$ \\
\hline Lactuca serriola ${ }^{\mathrm{a}}$ (prickly lettuce) & -- & $\mathrm{X}$ & -- & $\mathrm{X}$ \\
\hline Chondrilla juncea $^{\mathrm{a}}$ (rush skeletonweed) & -- & $\mathrm{X}$ & -- & $\mathrm{X}$ \\
\hline Centaurea diffusa ${ }^{\mathrm{a}}$ (diffuse knapweed) & -- & $\mathrm{X}$ & -- & $\mathrm{X}$ \\
\hline Biotic crust & 0 & 0 & 0 & 0 \\
\hline Soil & 47.5 & 32.1 & 100 & 93.3 \\
\hline Litter & 29.5 & 44.8 & 100 & 93.3 \\
\hline Total canopy cover (litter not included) & 38.7 & 0.2 & & \\
\hline \multicolumn{5}{|l|}{$\begin{array}{l}\text { a Invasive species } \\
X=\text { present but not counted in plot frames }\end{array}$} \\
\hline Total Invasive \% Cover & 29.7 & 56.1 & & \\
\hline Total Native \% Cover & 9.0 & 8.6 & & \\
\hline Change in Native \% Cover from 2009 & +3.7 & +3.4 & & \\
\hline
\end{tabular}

\subsection{REVEGETATION AT 100-F}

The 118-F-6, 120-F-1, and the 1607-F1 waste sites were revegetated in November 2008 and planted with Sandberg's bluegrass, Indian ricegrass, bluebunch wheatgrass, prairie junegrass, bottlebrush squirreltail, and needle-and-thread grass. In addition, $134 \mathrm{~kg} / \mathrm{ha}$ of Triple-16 fertilizer was added to the sites along with 4,480 kg/ha of straw mulch that was spread and crimped into the soil surface. Sagebrush, hopsage, and bitterbrush plugs were then planted into the seeded areas at 1,200 plants/ha.

\subsubsection{8-F-6 Burial Ground}

The 118-F-6 revegetation was monitored for the second year on June 7, 2010 (Figure 11). Russian thistle remained the dominant species on the site, with canopy cover increasing from $31 \%$ in 2009 to 38\% in 2010. Sandberg's bluegrass became the dominant native grass going on the site, with canopy cover increasing from $8.7 \%$. Five native planted bunchgrasses were observed on the site this year, with a sum total cover of 19\% (Table 13). 
Shrub monitoring showed sagebrush survival down from $84 \%$ in 2009 to $57 \%$ in 2010 . Of the 11 antelope bitterbrush recorded along the original transect, only one was still alive in 2010 , for a survival rate of $9 \%$. Overall shrub survival is at the low end in terms of meeting restoration goals, continued monitoring will show if additional revegetation actions will be required at this site.

Figure 11. 118-F-6 Burial Ground in 2010.

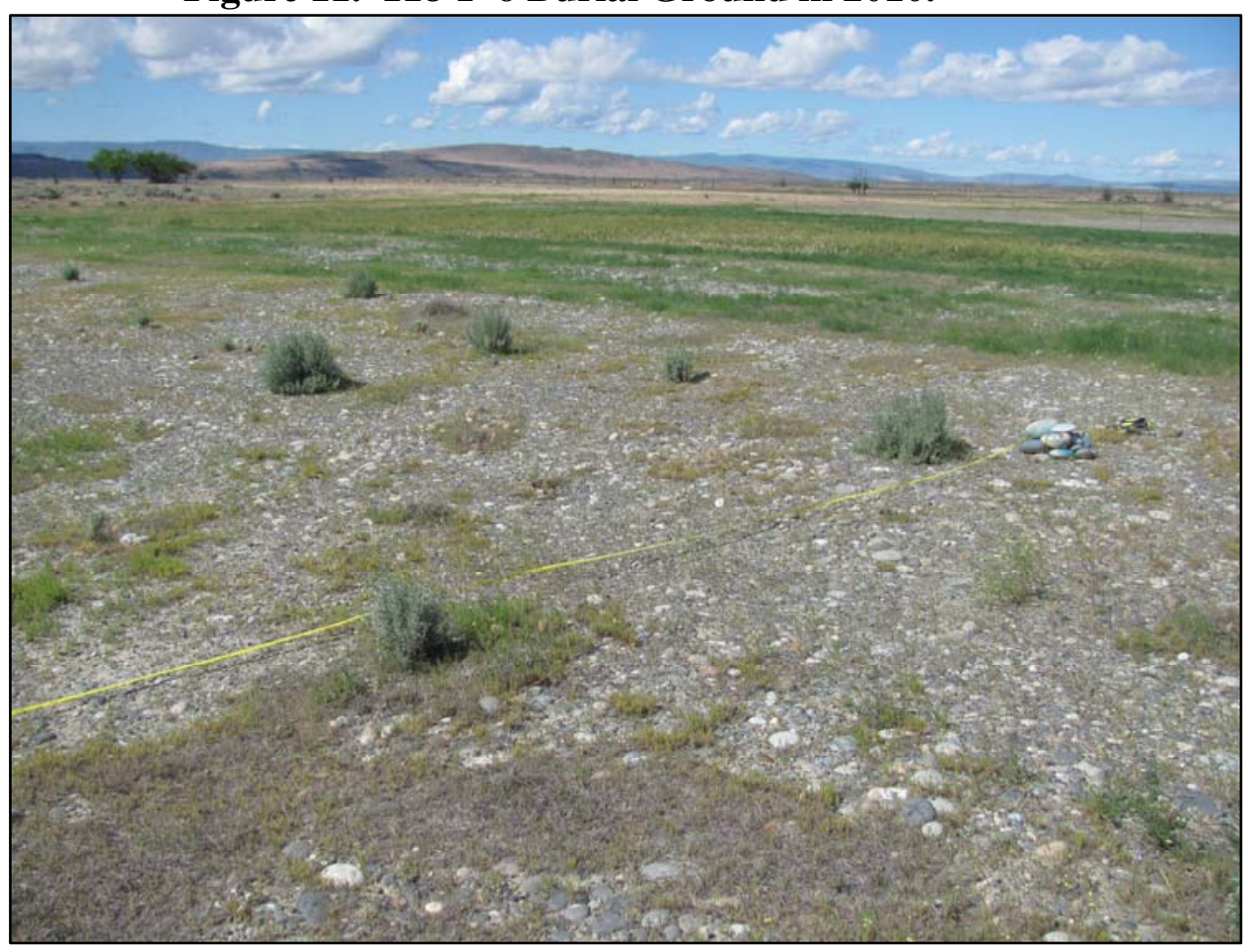

Sagebrush transect and planted shrubs at the 118-F-6 site in 2010. 
WCH-428

Rev. 0

Table 13. Percent Canopy Cover and Frequency of Occurrence at 118-F-6 in 2010.

\begin{tabular}{|c|c|c|}
\hline Species & \% Cover & $\%$ Freq of Occ \\
\hline Salsola kali (Russian thistle) & 37.5 & 96.0 \\
\hline Poa sandbergii (Sandberg's bluegrass) & 16.9 & 100.0 \\
\hline Sisymbrium altissimum ${ }^{\mathrm{a}}$ (tumble mustard) & 3.2 & 32.0 \\
\hline Bromus tectorum $^{\text {a }}$ (cheatgrass) & 2.1 & 44.0 \\
\hline Agropyron spicatum (bluebunch wheatgrass) & 1.2 & 48.0 \\
\hline Agropyron dasytachyum (thickspike wheatgrass) & 0.6 & 24.0 \\
\hline Oryzopsis hymenoides (Indian ricegrass) & 0.4 & 16.0 \\
\hline Achillea millefolium (yarrow) & 0.1 & 4.0 \\
\hline Descurainia pinnata (western tansymustard) & 0.1 & 4.0 \\
\hline Artemisia tridentata (big sagebrush) & $\mathrm{X}$ & $\mathrm{X}$ \\
\hline Lactuca serriola ${ }^{\mathrm{a}}$ (prickly lettuce) & $\mathrm{X}$ & $\mathrm{X}$ \\
\hline Purshia tridentata (antelope bitterbrush) & $\mathrm{X}$ & $\mathrm{X}$ \\
\hline Balsamorhiza careyana (Carey's balsamroot) & $\mathrm{X}$ & $\mathrm{X}$ \\
\hline Grayia spinosa (spiny hopsage) & $\mathrm{X}$ & $\mathrm{X}$ \\
\hline Cardaria draba ${ }^{\mathrm{a}}$ (whitetop) & $\mathrm{X}$ & $\mathrm{X}$ \\
\hline Tragopogon dubius (yellow salsify) & $\mathrm{X}$ & $\mathrm{X}$ \\
\hline Sitanion hystrix (bottlebrush squirreltail) & $\mathrm{X}$ & $\mathrm{X}$ \\
\hline Crust & 0.1 & 4.0 \\
\hline Soil & 70.2 & 96.0 \\
\hline Litter & 24.3 & 96.0 \\
\hline Total canopy cover (litter not included) & 62.1 & \\
\hline \multicolumn{3}{|l|}{$\begin{array}{l}{ }^{\mathrm{a}} \text { Invasive species } \\
\mathrm{X}=\text { present but not counted in plot frames }\end{array}$} \\
\hline Total Invasive \% Cover & 42.8 & \\
\hline Total Native \% Cover & 19.3 & \\
\hline Change in Native \% Cover from 2009 & 0 & \\
\hline
\end{tabular}




\subsubsection{0-F-1 Glass Dump}

Vegetation monitoring was performed at 120-F-1 site for the second year on May 19, 2010. Russian thistle cover dropped significantly, from 41\% cover in 2009 to only 2\% cover in 2010 (Table 14). Cheatgrass is now the dominant vegetation on the site, followed by the planted Sandberg's bluegrass. Native species diversity is extremely high for a second-year site, with 21 natives observed. The native topsoil was stockpiled and redistributed across this site, providing a seed source and good soil to provide for this high species diversity. Another contributing factor is the adjacent native habitat to this site, showing the importance of minimizing impacts and maintaining intact habitat in remediation areas. Planted sagebrush were observed as occurrences on this site but due to the small size, no monitoring transect was established.

Table 14. Percent Canopy Cover and Frequency of Occurrence at 120-F-1 in 2010.

\begin{tabular}{|c|c|c|}
\hline Species & \% Cover & $\%$ Freq of Occ \\
\hline Bromus tectorum $^{\mathrm{a}}$ (cheatgrass) & 27.2 & 100.0 \\
\hline Poa sandbergii (Sandberg's bluegrass) & 9.7 & 100.0 \\
\hline Holosteum umbellatum ${ }^{\text {a }}$ (jagged chickweed) & 4.0 & 93.3 \\
\hline Draba verna $^{\text {a }}$ (spring whitlowgrass) & 2.3 & 93.3 \\
\hline Salsola kali (Russian thistle) & 1.7 & 66.7 \\
\hline Microsteris gracilis (pink microsteris) & 1.7 & 66.7 \\
\hline Sisymbrium altissimum $^{\mathrm{a}}$ (tumble mustard) & 1.5 & 60.0 \\
\hline Agropyron spicatum (bluebunch wheatgrass) & 1.0 & 40.0 \\
\hline Oryzopsis hymenoides (Indian ricegrass) & 0.8 & 33.3 \\
\hline Plantago patagonica (Indian wheat) & 0.8 & 33.3 \\
\hline Stipa comata (needle-and-thread grass) & 0.5 & 20.0 \\
\hline Sitanion hystrix (bottlebrush squirreltail) & 0.5 & 20.0 \\
\hline Achillea millefolium (yarrow) & 0.3 & 13.3 \\
\hline Amsinckia lycopsoides (tarweed fiddleneck) & 0.3 & 13.3 \\
\hline Lactuca serriola ${ }^{\mathrm{a}}$ (prickly lettuce) & 0.3 & 13.3 \\
\hline Festuca octoflora (slender sixweeks) & 0.2 & 6.7 \\
\hline Oenothera pallida (pale evening primrose) & 0.2 & 6.7 \\
\hline Astragalus caricinus (buckwheat milkvetch) & 0.2 & 6.7 \\
\hline Agoseris heterophylla (mountain dandelion) & 0.2 & 6.7 \\
\hline Descurainia pinnata (western tansymustard) & 0.2 & 6.7 \\
\hline Artemisia tridentata (big sagebrush) & $\mathrm{X}$ & $\mathrm{X}$ \\
\hline Phacelia linearis (threadleaf phacelia) & $\mathrm{X}$ & $\mathrm{X}$ \\
\hline Gilia leptomeria (Great Basin gilia) & $\mathrm{X}$ & $\mathrm{X}$ \\
\hline Phlox longifolia (longleaf phlox) & $\mathrm{X}$ & $\mathrm{X}$ \\
\hline Chaenactis douglasii (hoary falseyarrow) & $\mathrm{X}$ & $\mathrm{X}$ \\
\hline Poa bulbosa ${ }^{\mathrm{a}}$ (bulbous bluegrass) & $\mathrm{X}$ & $\mathrm{X}$ \\
\hline Astragalus sclerocarpus (stalked pod milkvetch) & $\mathrm{X}$ & $\mathrm{X}$ \\
\hline Eriogonum niveum (snow buckwheat) & $\mathrm{X}$ & $\mathrm{X}$ \\
\hline Biotic crust & 0.0 & 0.0 \\
\hline Bare soil & 42.7 & 100.0 \\
\hline Litter & 33.2 & 100.0 \\
\hline Total canopy cover (litter not included) & 53.5 & \\
\hline \multicolumn{3}{|l|}{${ }^{\mathrm{a}}$ Invasive species } \\
\hline \multicolumn{3}{|l|}{$\mathrm{X}=$ present but not counted in plot frames } \\
\hline Total Invasive \% Cover & 18.7 & \\
\hline Total Native \% Cover & 34.8 & \\
\hline Change in Native \% Cover from 2009 & +18.3 & \\
\hline
\end{tabular}




\subsubsection{7-F1 Septic Tank}

Second-year vegetation monitoring was performed at the 1607-F1 site on June 7, 2010 (Figure 12). Although Russian thistle was still observed as the dominant species on the site, canopy cover dropped from 60\% in 2009 to 28\% in 2010 (Table 15). Sandberg's bluegrass increased canopy cover from 14\% in 2009 to 16\% in 2010, although cheatgrass was the dominant grass on the site at $19 \%$ cover. This is still a relatively young revegetation area, as the planted perennial bunchgrasses, such as bottlebrush squirreltail and bluebunch wheatgrass, continue to grow and mature they will likely begin to outcompete the annual non-native species for resources.

The sagebrush monitoring performed at the site showed 56\% of the planted sagebrush surviving. This represents a significant drop from initial monitoring, but is still meeting restoration goals at this time. Subsequent monitoring efforts will show if the shrubs start to bloom and generate recruits at the site, and if survival rates will begin to stabilize.

Figure 12. 1607-F1 in 2010.

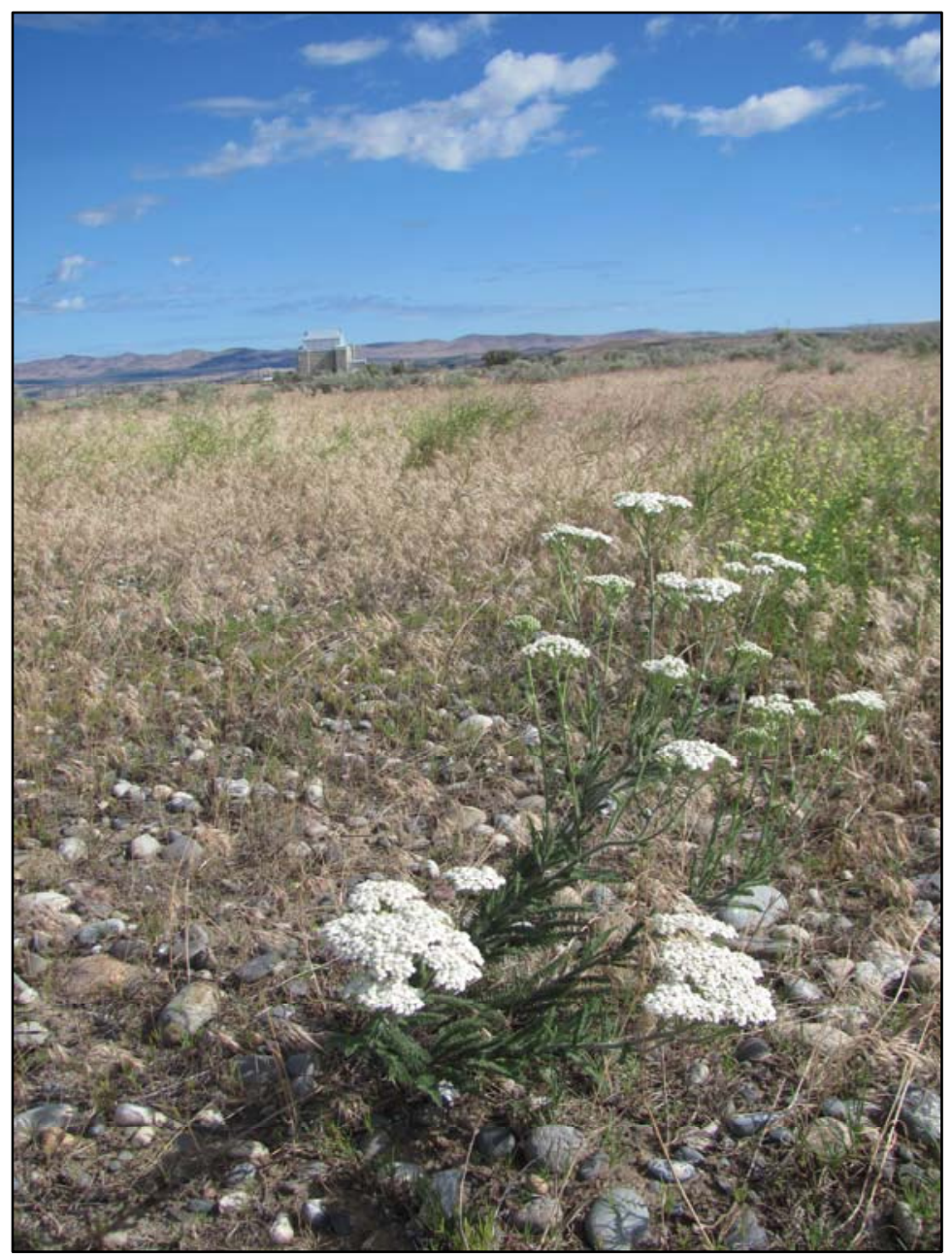

Volunteer yarrow at the 1607-F1, with 105-F Reactor in the background. 
Table 15. Percent Canopy Cover and Frequency of Occurrence at 1607-F1 in 2010.

\begin{tabular}{|c|c|c|}
\hline Species & \% Cover & $\%$ Freq of Occ \\
\hline Salsola kali (Russian thistle) & 28.0 & 100.0 \\
\hline Bromus tectorum ${ }^{\text {a }}$ (cheatgrass) & 18.5 & 100.0 \\
\hline Poa sandbergii (Sandberg's bluegrass) & 16.2 & 100.0 \\
\hline Sitanion hystrix (bottlebrush squirreltail) & 4.3 & 46.7 \\
\hline Sisymbrium altissimum ${ }^{\mathrm{a}}$ (tumble mustard) & 3.8 & 60.0 \\
\hline Agropyron spicatum (bluebunch wheatgrass) & 2.2 & 86.7 \\
\hline 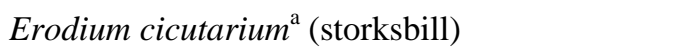 & 0.5 & 20.0 \\
\hline Draba verna ${ }^{\mathrm{a}}$ (spring whitlowgrass) & 0.3 & 13.3 \\
\hline Holosteum umbellatum ${ }^{\mathrm{a}}$ (jagged chickweed) & 0.2 & 6.7 \\
\hline Achillea millefolium (yarrow) & 0.2 & 6.7 \\
\hline Artemisia tridentata (big sagebrush) & 0.2 & 6.7 \\
\hline Sphaeralcea munroana (Munro's globemallow) & 0.2 & 6.7 \\
\hline Festuca octoflora (slender sixweeks) & 0.2 & 6.7 \\
\hline Oryzopsis hymenoides (Indian ricegrass) & $\mathrm{X}$ & $\mathrm{X}$ \\
\hline Descurainia pinnata (western tansymustard) & $\mathrm{X}$ & $\mathrm{X}$ \\
\hline Plantago patagonica (Indian wheat) & $\mathrm{X}$ & $\mathrm{X}$ \\
\hline Ambrosia acanthicarpa (bur ragweed) & $\mathrm{X}$ & $\mathrm{X}$ \\
\hline Verbena bracteata $^{\text {a }}$ (big-bract verbena) & $\mathrm{X}$ & $\mathrm{X}$ \\
\hline Lactuca serriola ${ }^{\mathrm{a}}$ (prickly lettuce) & $\mathrm{X}$ & $\mathrm{X}$ \\
\hline Astragalus caricinus (buckwheat milkvetch) & $\mathrm{X}$ & $\mathrm{X}$ \\
\hline Sporobolus cryptandrus (sand dropseed) & $\mathrm{X}$ & $\mathrm{X}$ \\
\hline Grayia spinosa (spiny hopsage) & $\mathrm{X}$ & $\mathrm{X}$ \\
\hline Chrysothamnus nauseosus (gray rabbitbrush) & $\mathrm{X}$ & $\mathrm{X}$ \\
\hline Poa bulbosa $a^{\text {a }}$ (bulbous bluegrass) & $\mathrm{X}$ & $\mathrm{X}$ \\
\hline Crust & 0.0 & 0.0 \\
\hline Soil & 57.0 & 100.0 \\
\hline Litter & 39.5 & 100.0 \\
\hline Total canopy cover (litter not included) & 74.7 & \\
\hline \multicolumn{3}{|l|}{$\begin{array}{l}{ }^{\mathrm{a}} \text { Invasive species } \\
\mathrm{X}=\text { present but not counted in plot frames }\end{array}$} \\
\hline $\begin{array}{l}\text { Total Invasive \% Cover } \\
\text { Total Native \% Cover } \\
\text { Change in Native \% Cover from } 2009\end{array}$ & $\begin{array}{l}51.3 \\
23.3 \\
+6.8\end{array}$ & \\
\hline
\end{tabular}




\section{$3.5 \quad$ 100-B/C SITES PLANTED IN 2006}

In 2006, waste sites 100-B-1, 128-C-1, and 600-232 in the 100-B/C Area were revegetated after completion of remedial actions to meet the objectives for interim closure as established in the Remedial Design Report/Remedial Action Work Plan for the 100 Area (RDR/RAWP) (DOE-RL 2005a) and the Interim Action Record of Decision for the 100-BC-1, 100-BC-2, 100-DR-1, 100-DR-2, 100-FR-1, 100-FR-2, 100-HR-1, 100-HR-2, 100-KR-1, 100-KR-2, 100-IU-2, 100-IU-6, and 200-CW-3 Operable Units, Hanford Site, Benton County, Washington (EPA 1999). The remediated sites that required backfill used material from borrow pit 24, located west of the 100-B/C Area. The 100-B-1 site was backfilled with borrow pit material, then a thin layer of topsoil that was salvaged from the waste staging pile area was spread over the borrow pit material. The 128-C-1 site was backfilled to grade with pit run cobble. The 600-232 site did not require backfill as the site was primarily surface debris that was picked up, with only the top 12 in. of soil being removed from a portion of the site. All three sites were broadcast seeded in the winter of 2006 with a native grass seed mix that included Sandberg's bluegrass, needle-and-thread grass, Indian ricegrass, bluebunch wheatgrass, prairie junegrass, and thickspike wheatgrass. Triple-16 fertilizer and polyacrylamide was applied with the grass seed. Upon the completion of seeding, the entire area was irrigated with 23,400 L/ha then mulched with 4.5 metric tons/ ha straw and crimped into the soil surface to prevent wind erosion. The sites were then planted with 16,000 sagebrush and 600 spiny hopsage seedlings (Figure 13).

Fifth-year vegetation monitoring was performed at the 100-B-1 and 128-C-1 on April 22 and April 26, 2010, respectively (Table 16). Sandberg's bluegrass has been the dominant species at both sites for several years, and its establishment is likely provides enough competition to account for the relatively low percentages of canopy cover observed for non-natives species across these sites. Figures 13 and 14 show the changes in canopy cover of the Sandberg's bluegrass, cheatgrass, and Russian thistle over the 5 years of monitoring at these sites. The reduction over time of the canopy cover of Russian thistle is one indication of a successful revegetation effort. The good fine-grained soil at the 100-B-1 site has allowed for a strong stand of Sandberg's bluegrass to become established over the years, which has resulted in a low canopy of cheatgrass. The drop in overall canopy cover for both Sandberg's bluegrass and cheatgrass was observed at these sites along with most other areas monitored in 2010. This reduction is suspected to be due to the abnormally slow start to the growing season, but is not expected to be seen in the long-term. Eighteen native species are present across the two sites, including many native forbs that have naturally reestablished in the areas. Figures 15 and 16 show the visible comparison of conditions observed during first year monitoring to current conditions at 100-B-1 and 128-C-1, respectively.

Shrub transects were monitored at both sites in 2010. Sagebrush has become well established at both sites as a result of the initial tubeling plantings. The transect at $100-\mathrm{B}-1$ showed $53.2 \%$ survival, while $128-\mathrm{C}-1$ showed $48 \%$ of the shrubs along the transect surviving. Many of these shrubs, $78.6 \%$ at $100-\mathrm{B}-1$ and $88 \%$ at $128-\mathrm{C}-1$, bloomed in the previous year. The shrubs at these sites have been blooming for several years, and many well-established recruits can be seen across these sites. All of this information combines to show this revegetation effort has successfully established sagebrush at both sites. 
Overall, these two sites have been successfully revegetated. They are dominated by native grasses, with a significant number of native forbs in the understory. The canopy of non-natives is relatively low, and shrubs have been well established and are producing recruits.

\section{Figure 13. Canopy Cover Changes of Selected Species Over Time at 100-B-1.}

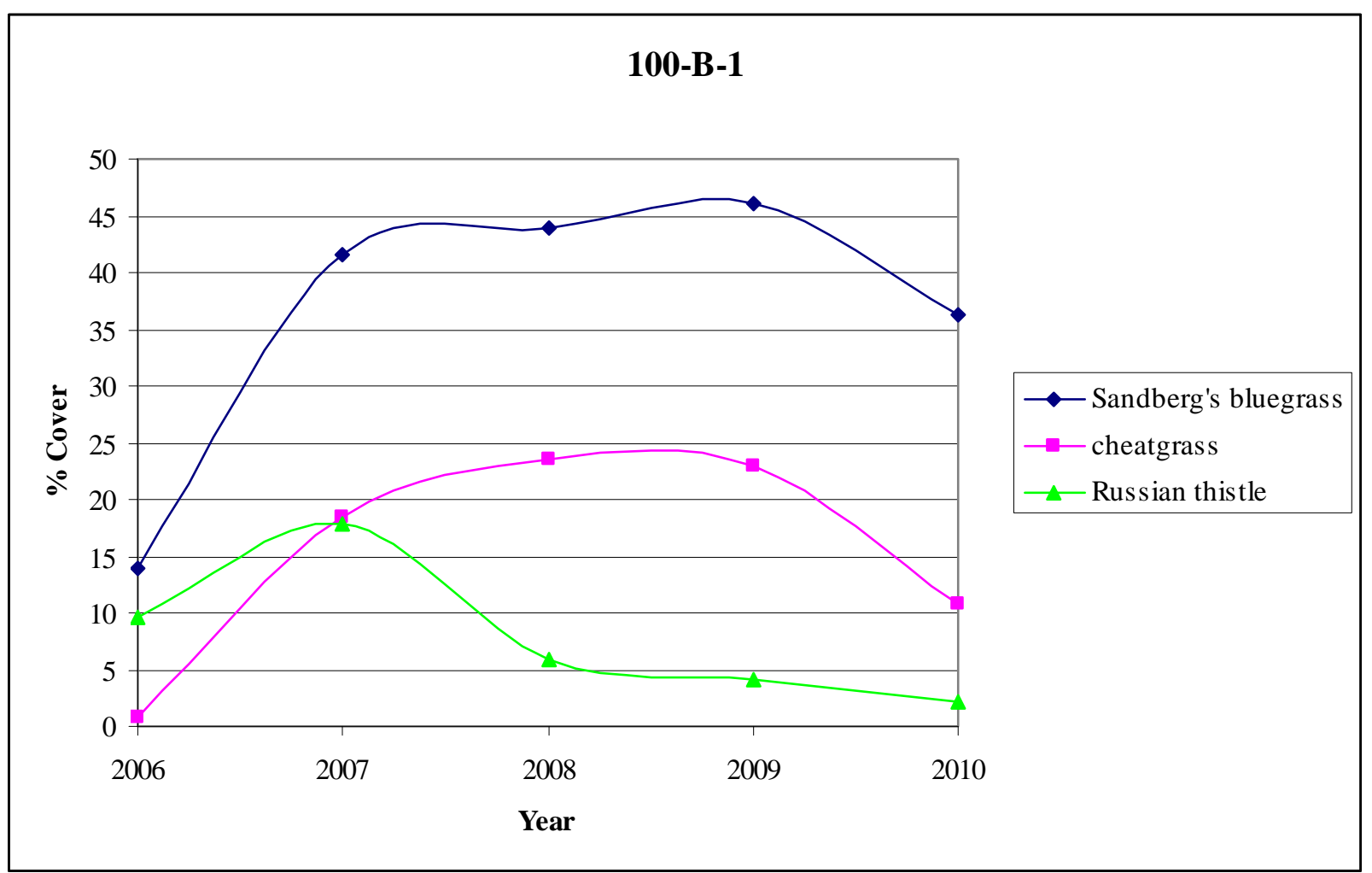


Figure 14. Canopy Cover Changes of Selected Species Over Time at 128-C-1.

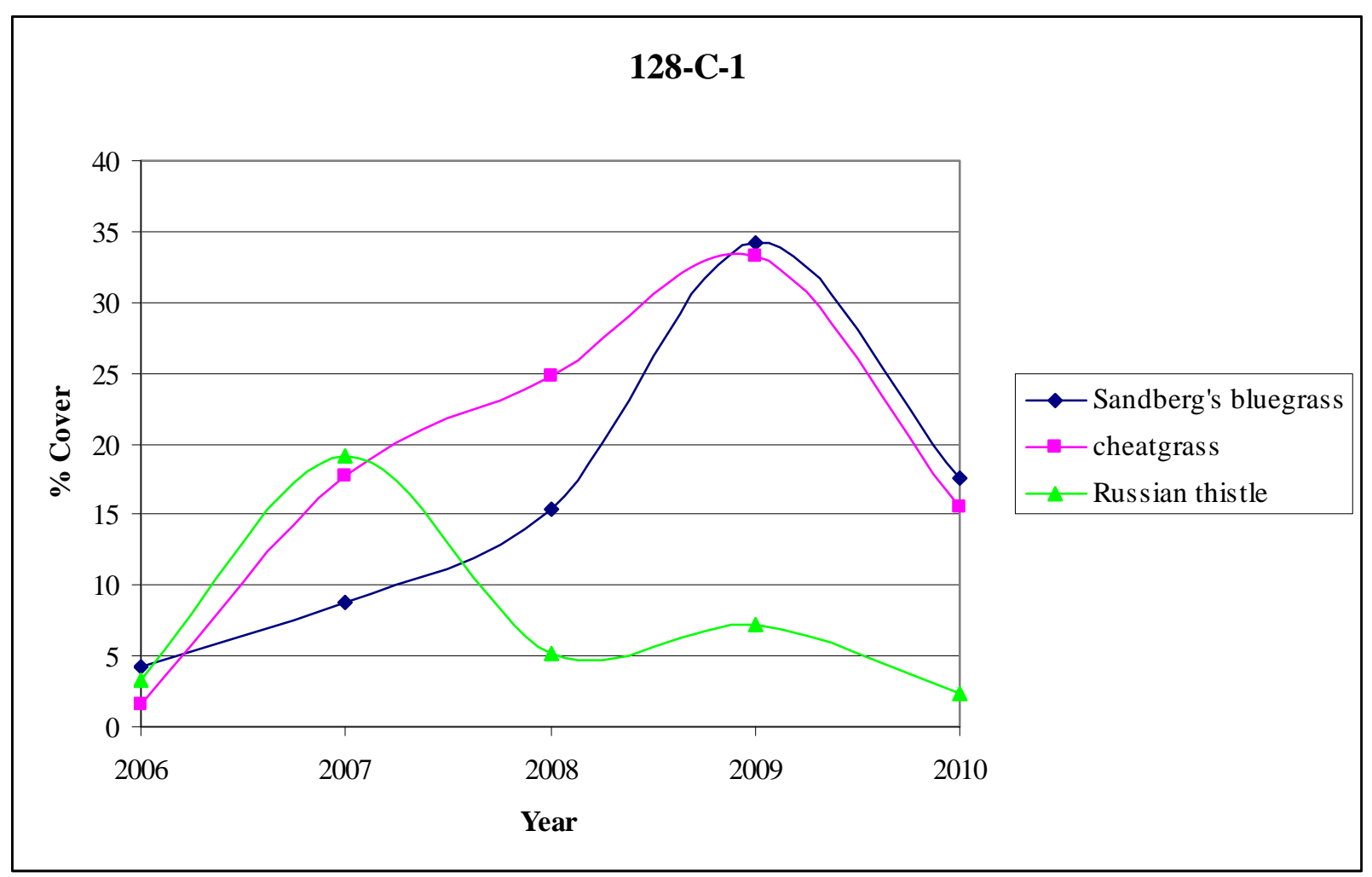


Figure 15. 100-B-1 Dumping Area.

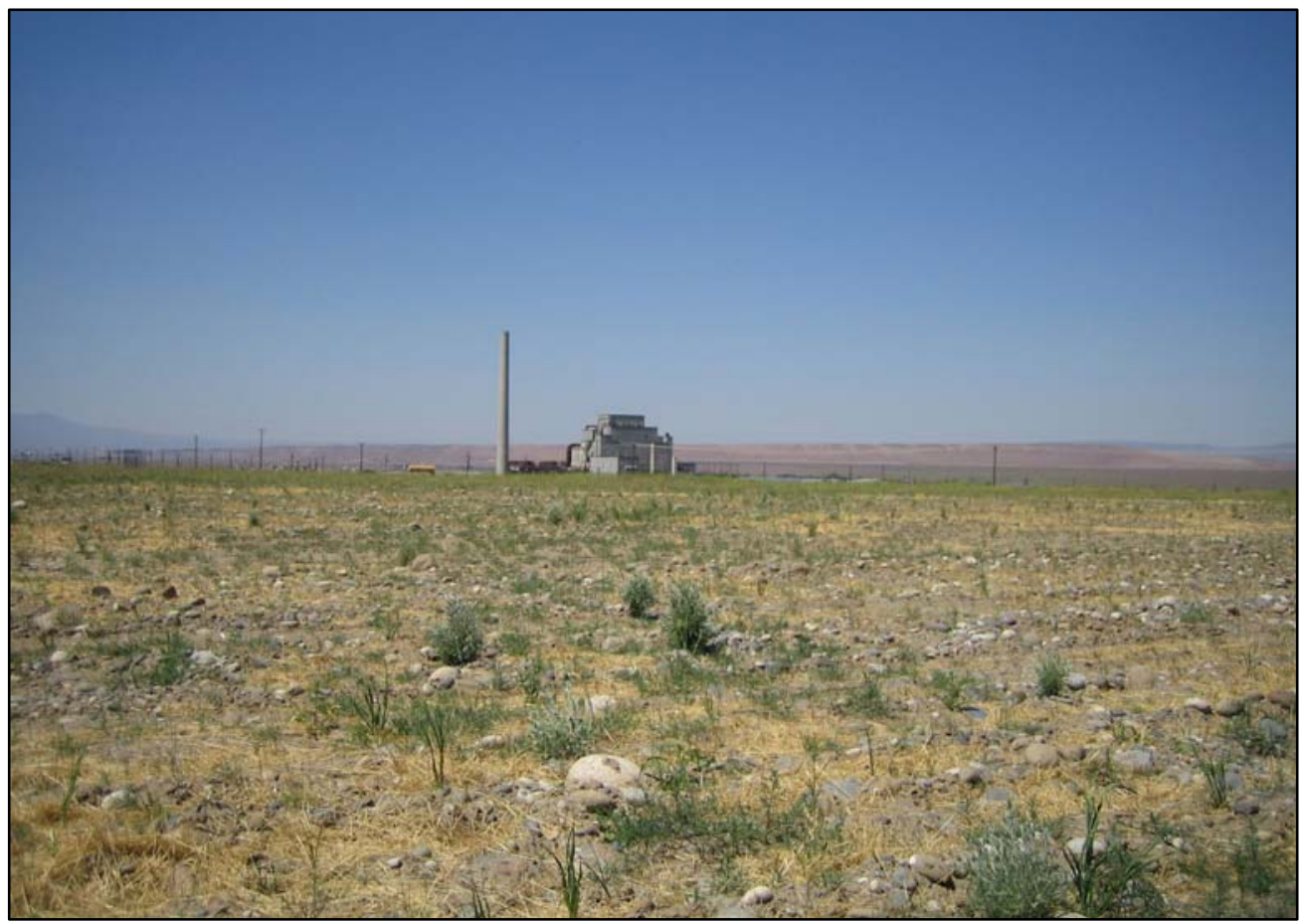

100-B-1 site in 2006 showing newly planted shrubs and grasses, along with straw mulch.

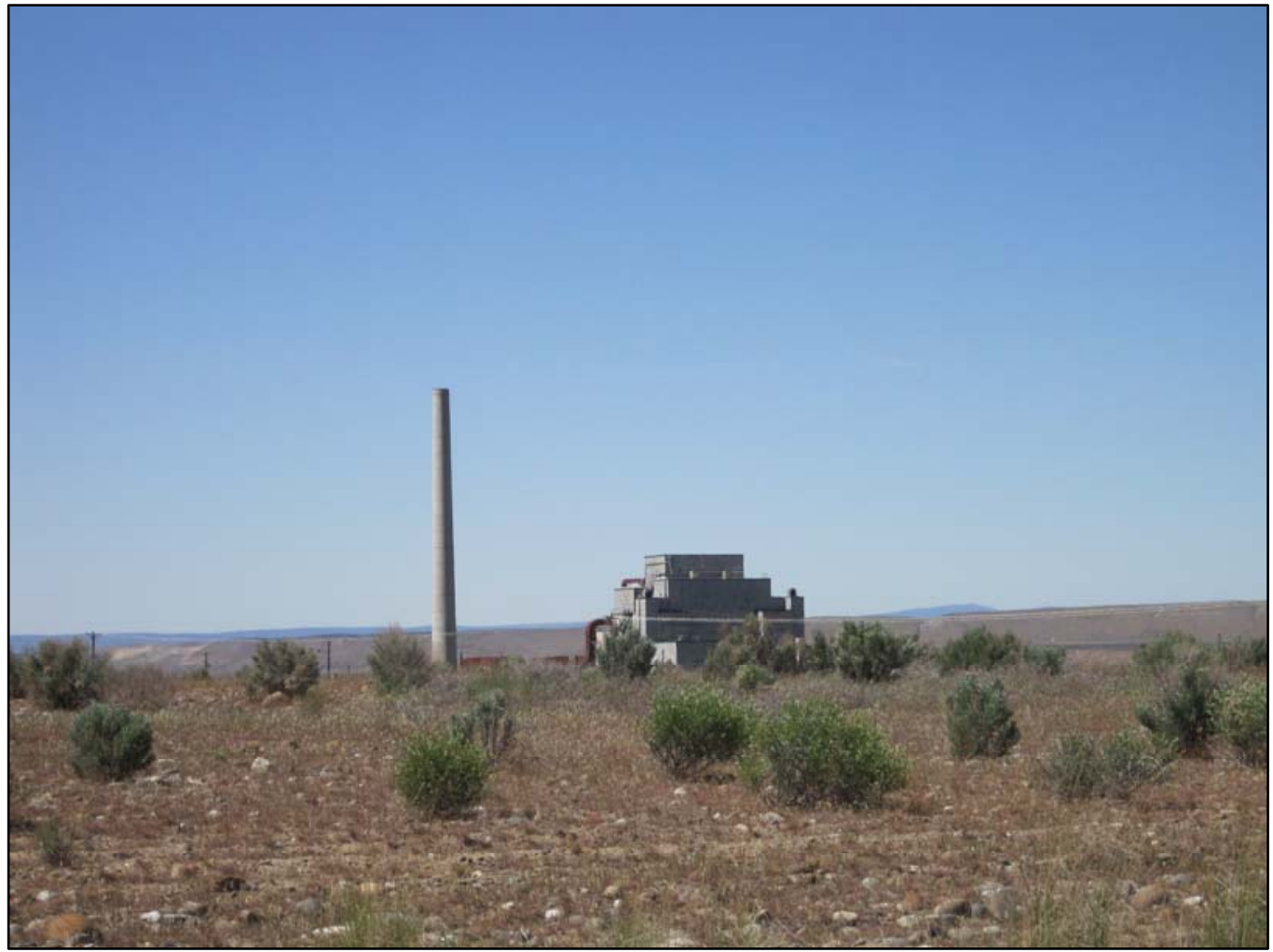

Sagebrush and hopsage growing at 100-B-1 in 2010. 
Figure 16. 128-C-1 Burn Pit.

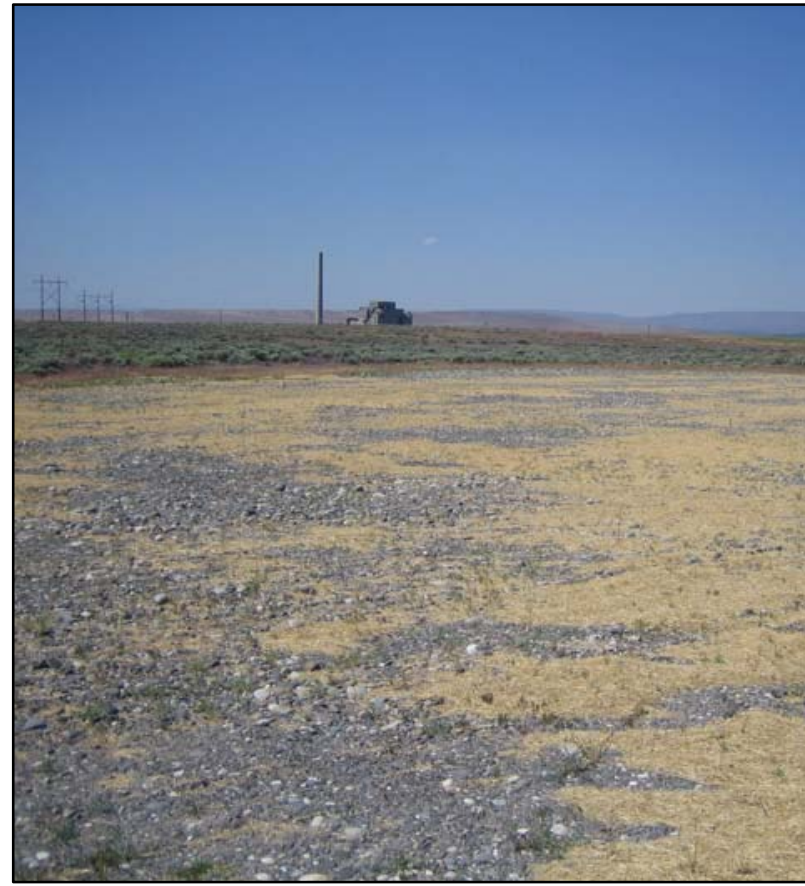

128-C-1 during first-year monitoring (2006).

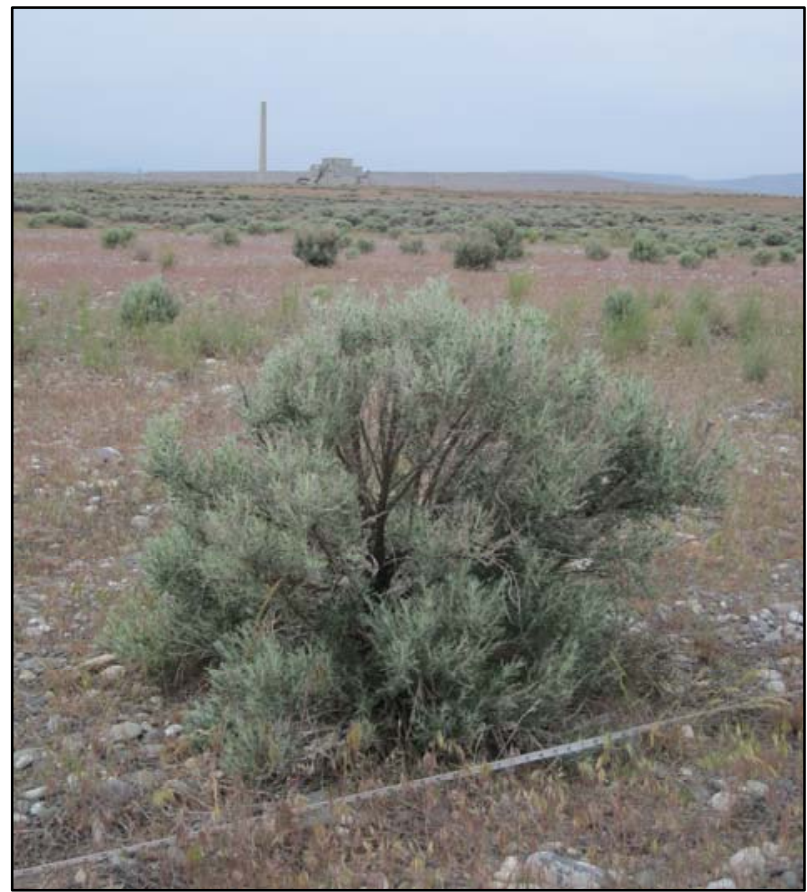

128-C-1 during final-year monitoring (2010).

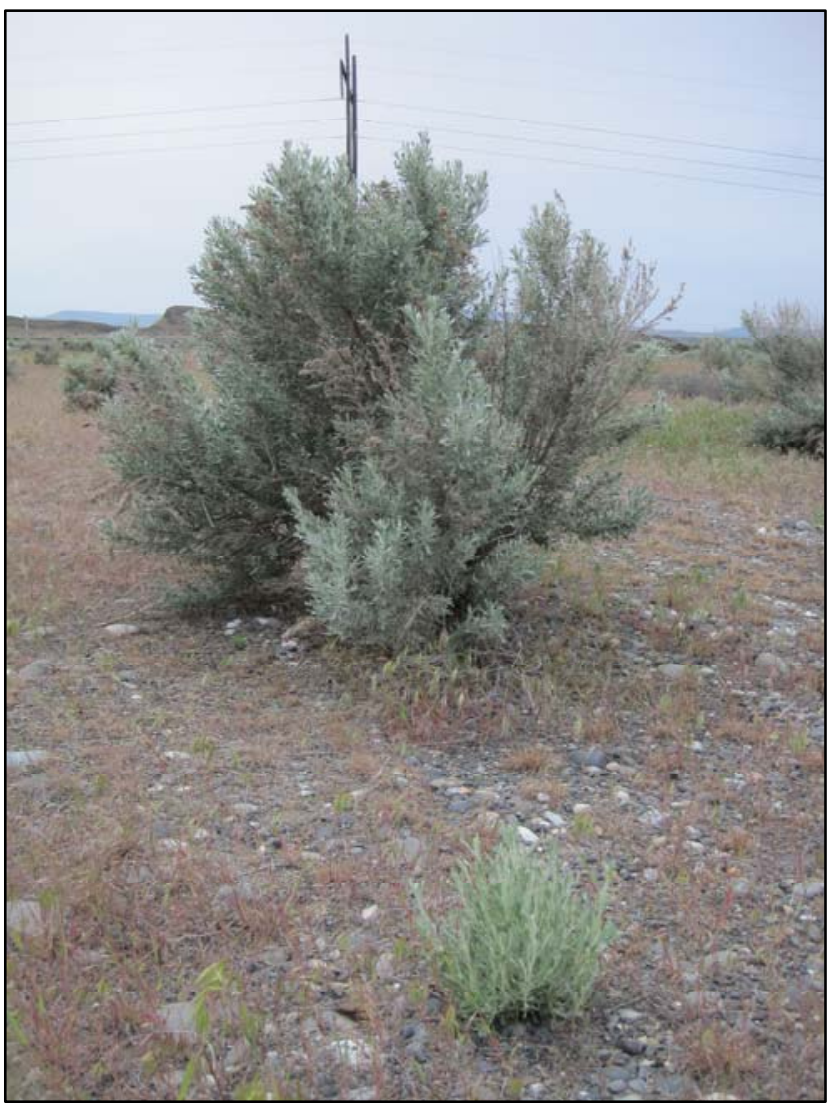

Planted sagebrush (background) and well-established recruit (foreground) in 2010. 
Table 16. Percent Canopy Cover and Frequency of Occurrence at 100-B-1 and 128-C-1 in 2010.

\begin{tabular}{|c|c|c|c|c|}
\hline Species & $\begin{array}{l}\text { \% Cover } \\
\text { 100-B-1 }\end{array}$ & $\begin{array}{l}\text { \% Cover } \\
128-C-1 \\
\end{array}$ & $\begin{array}{c}\text { \% Freq of Occ } \\
100-B-1 \\
\end{array}$ & $\begin{array}{c}\text { \% Freq of Occ } \\
128-C-1 \\
\end{array}$ \\
\hline Poa sandbergii (Sandberg's bluegrass) & 36.3 & 17.7 & 100.0 & 100.0 \\
\hline Bromus tectorum $^{a}$ (cheatgrass) & 10.7 & 15.5 & 100.0 & 100.0 \\
\hline Salsola kali $^{\text {a }(\text { Russian thistle) }}$ & 2.2 & 2.3 & 88.0 & 93.3 \\
\hline Agropyron spicatum (bluebunch wheatgrass) & 2.0 & 1.2 & 40.0 & 13.3 \\
\hline Artemisia tridentata (big sagebrush) & 1.1 & 0.8 & 44.0 & 33.3 \\
\hline Lactuca serriola ${ }^{\mathrm{a}}$ (prickly lettuce) & -- & 0.8 & -- & 33.3 \\
\hline Draba verna ${ }^{\mathrm{a}}$ (spring whitlowgrass) & -- & 0.7 & -- & 26.7 \\
\hline Sitanion hystrix (bottlebrush squirreltail) & 0.2 & 0.7 & 8.0 & 26.7 \\
\hline Sisymbrium altissimum ${ }^{\mathrm{a}}$ (tumble mustard) & 0.6 & 0.2 & 24.0 & 6.7 \\
\hline Microsteris gracilis (pink microsteris) & 0.6 & $\mathrm{X}$ & 24.0 & $\mathrm{X}$ \\
\hline Chrysothamnus nauseosus (gray rabbitbrush) & -- & 0.5 & -- & 20.0 \\
\hline Oryzopsis hymenoides (Indian ricegrass) & 0.1 & 0.3 & 4.0 & 13.3 \\
\hline Holosteum umbellatum ${ }^{\text {a }}$ (jagged chickweed) & 0.1 & 0.2 & 4.0 & 6.7 \\
\hline Machaeranthera canescens (hoary aster) & -- & 0.2 & -- & 6.7 \\
\hline Poa scabrella (pine bluegrass) & 0.1 & -- & 4.0 & -- \\
\hline Lomatium macrocarpum (bigseed desertparsley) & 0.1 & -- & 4.0 & -- \\
\hline Agropyron dasytachyum (thickspike wheatgrass) & 0.1 & -- & 4.0 & -- \\
\hline Astragalus sclerocarpus (stalked pod milkvetch) & 0.1 & $\mathrm{X}$ & 4.0 & $\mathrm{X}$ \\
\hline Descurainia pinnata (western tansymustard) & & $\mathrm{X}$ & & $\mathrm{X}$ \\
\hline Amsinckia lycopsoides (tarweed fiddleneck) & $\mathrm{X}$ & -- & $\mathrm{X}$ & -- \\
\hline Sphaeralcea munroana (Munro's globemallow) & $\mathrm{X}$ & $\mathrm{X}$ & $\mathrm{X}$ & $\mathrm{X}$ \\
\hline Balsamorhiza careyana (Carey's balsamroot) & $\mathrm{X}$ & -- & $\mathrm{X}$ & -- \\
\hline Grayia spinosa (spiny hopsage) & $\mathrm{X}$ & -- & $\mathrm{X}$ & -- \\
\hline Erigeron pumilus (shaggy fleabane) & $\mathrm{X}$ & -- & $\mathrm{X}$ & -- \\
\hline Centaurea diffusa $a^{\mathrm{a}}$ (diffuse knapweed) & -- & $\mathrm{X}$ & -- & $\mathrm{X}$ \\
\hline 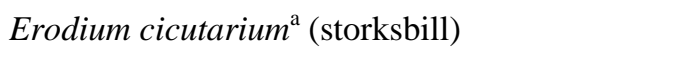 & -- & $\mathrm{X}$ & -- & $\mathrm{X}$ \\
\hline Erigeron poliospermus (cushion fleabane) & -- & $\mathrm{X}$ & -- & $\mathrm{X}$ \\
\hline Chondrilla juncea $^{\mathrm{a}}$ (rush skeletonweed) & -- & $\mathrm{X}$ & -- & $\mathrm{X}$ \\
\hline Crust & 2.5 & 0.7 & 80.0 & 26.7 \\
\hline Soil & 55.3 & 47.7 & 100.0 & 100.0 \\
\hline Litter & 27.9 & 38.2 & 100.0 & 100.0 \\
\hline Total canopy cover (litter not included) & 54.1 & 41.0 & & \\
\hline \multicolumn{5}{|l|}{$\begin{array}{l}{ }^{\mathrm{a}} \text { Invasive species } \\
\mathrm{X}=\text { present but not counted in plot frames }\end{array}$} \\
\hline Total Invasive \% Cover & 13.6 & 19.7 & & \\
\hline Total Native \% Cover & 40.5 & 21.3 & & \\
\hline Change in Native \% Cover from 2009 & -13.4 & -18.4 & & \\
\hline
\end{tabular}




\subsection{0-B/C SITES PLANTED IN 2007}

In 2007, the following waste sites in the 100-B/C Area were revegetated: 100-B-8, a portion of 100-B-14, 100-C-9, 126-B-3, 128-B-2, 128-B-3, 118-B-2, 118-B-3, and 1607-B-2. These sites were remediated to meet the objectives for interim closure as established in the Remedial Design Report/Remedial Action Work Plan for the 100 Area (RDR/RAWP) (DOE-RL 2005a) and in the Interim Action Record of Decision for the 100-BC-1, 100-BC-2, 100-DR-1, 100-DR-2, 100-FR-1, 100-FR-2, 100-HR-1, 100-HR-2, 100-KR-1, 100-KR-2, 100-IU-2, 100-IU-6, and 200-CW-3 Operable Units, Hanford Site, Benton County, Washington (EPA 1999).

The total area that was revegetated was approximately 100 acres. The sites were backfilled with pit-run gravel from borrow pit 24 and then revegetated by broadcast seeding with a native grass seed mix that included Sandberg's bluegrass, needle-and-thread grass, Indian ricegrass, bluebunch wheatgrass, prairie junegrass, and bottlebrush squirreltail. Triple-16 fertilizer and polyacrylamide was applied with the grass seed. Upon the completion of seeding, the entire area was mulched with 4.5 metric tons/ha straw and crimped into the soil surface to prevent wind erosion. Upon completion of seeding, the sites were planted with sagebrush at approximately 1,300 plants/ha (530 plants/ac).

Fourth-year vegetation monitoring was performed at the 100-C-9 site on May 12, 2010. This site was broken out into three areas, each with separate vegetation monitoring sets and sagebrush transects, in order to increase the resolution of the monitoring. Transect 1 remains the most successful area at this site, with Sandberg's being the dominant species and non-native canopy cover at a low 11\%. At Transect 2, Sandberg's bluegrass appears to be starting to compete with cheatgrass for available resources. In 2009, Sandberg's bluegrass was only observed at $10 \%$ cover at T2, while cheatgrass was observed at $43 \%$ cover. In contrast, 2010 monitoring showed Sandberg's increasing to $12 \%$ cover, while cheatgrass was only seen at $18 \%$ cover (Table 17 ). At this rate, Sandberg's bluegrass may be the dominant species at T2 in 2011. Transect 3 remains heavily invaded and dominated by cheatgrass, with a canopy cover of $29 \%$. Comparatively, Sandberg's bluegrass was only recorded at $10 \%$ cover at T3. Indian ricegrass is beginning to take a foot-hold at these sites, showing up in $60 \%$ of the plot frames at $\mathrm{T} 1$ and $\mathrm{T} 2$, and $13 \%$ of the frames in T3. This perennial bunchgrass will compete well with non-natives as it grows and matures.

Sagebrush monitoring at Transect 1 showed 90\% survival, with 97\% of the shrubs alive in 2009 still surviving and $3 \%$ blooming in the previous year. Transect 2 showed $95 \%$ survival, losing only 1 of the 75 shrubs recorded alive in 2009; 3\% of the shrubs on the transect were blooming. Transect 3 showed $62 \%$ survival, with 91\% of the shrubs recorded alive in 2009 still surviving. Interestingly, $24 \%$ of the shrubs on this site bloomed in the previous year. So although T3 shows lower survival rates, more of the remaining shrubs are blooming, which may in turn result in a greater level of recruitment. Continued observation will show if recruitment is different across the three sites. 
Table 17. Percent Canopy Cover and Frequency of Occurrence at 100-C-9 in 2010.

\begin{tabular}{|c|c|c|c|c|c|c|}
\hline Species & $\begin{array}{l}\text { T1\% } \\
\text { Cover }\end{array}$ & $\begin{array}{l}\mathrm{T} 2 \% \\
\text { Cover }\end{array}$ & $\begin{array}{l}\mathrm{T} 3 \% \\
\text { Cover }\end{array}$ & $\begin{array}{c}\text { T1 \% Freq } \\
\text { of Occ }\end{array}$ & $\begin{array}{c}\text { T2 \% Freq } \\
\text { of Occ }\end{array}$ & $\begin{array}{c}\text { T3 \% Freq } \\
\text { of Occ }\end{array}$ \\
\hline Bromus tectorum ${ }^{\mathrm{a}}$ (cheatgrass) & 7.3 & 17.5 & 28.7 & 100.0 & 100.0 & 100.0 \\
\hline Poa sandbergii (Sandberg's bluegrass) & 21.7 & 12.2 & 9.8 & 100.0 & 100.0 & 100.0 \\
\hline Salsola kali ${ }^{\text {a }}$ (Russian thistle) & 2.5 & 2.2 & 2.0 & 100.0 & 86.7 & 80.0 \\
\hline Oryzopsis hymenoides (Indian ricegrass) & 1.5 & 1.5 & 0.3 & 60.0 & 60.0 & 13.3 \\
\hline Chrysothamnus nauseosus (gray rabbitbrush) & 0.8 & 1.3 & 0.3 & 33.3 & 53.3 & 13.3 \\
\hline Artemisia tridentata (big sagebrush) & 0.2 & 1.3 & 0.5 & 6.7 & 20.0 & 20.0 \\
\hline Erigonum vimineum (broom buckwheat) & -- & 0.8 & -- & -- & 33.3 & -- \\
\hline Agropyron spicatum (bluebunch wheatgrass) & 0.7 & 0.5 & 0.3 & 26.7 & 20.0 & 13.3 \\
\hline Sisymbrium altissimum ${ }^{\mathrm{a}}$ (tumble mustard) & 0.2 & 0.3 & 0.5 & 6.7 & 13.3 & 20.0 \\
\hline Holosteum umbellatum ${ }^{\mathrm{a}}$ (jagged chickweed) & 0.3 & 0.3 & 0.3 & 13.3 & 13.3 & 13.3 \\
\hline Draba verna $^{\text {a }}$ (spring whitlowgrass) & 0.2 & 0.3 & 0.3 & 6.7 & 13.3 & 13.3 \\
\hline Cryptantha circumscissa (matted cryptantha) & 0.3 & -- & -- & 13.3 & -- & -- \\
\hline Festuca octoflora (slender sixweeks) & 0.3 & -- & -- & 13.3 & -- & -- \\
\hline Centaurea diffusa $a^{\mathrm{a}}$ (diffuse knapweed) & -- & 0.2 & 0.5 & -- & 6.7 & 20.0 \\
\hline Chaenactis douglasii (hoary falseyarrow) & -- & 0.2 & -- & -- & 6.7 & -- \\
\hline Machaeranthera canescens (hoary aster) & $\mathrm{X}$ & $\mathrm{X}$ & -- & $\mathrm{X}$ & $\mathrm{X}$ & -- \\
\hline Sporobolus cryptandrus (sanddrop seed) & & $\mathrm{X}$ & -- & & $\mathrm{X}$ & -- \\
\hline Sitanion hystrix (bottlebrush squirreltail) & 0.2 & $\mathrm{X}$ & 0.2 & 6.7 & $\mathrm{X}$ & 6.7 \\
\hline $\begin{array}{l}\text { Tragopogon dubius }{ }^{\text {a }} \text { yellow salsify) } \\
\text { Agropyron dasytachyum (thickspike }\end{array}$ & -- & $\mathrm{X}$ & -- & -- & $\mathrm{X}$ & -- \\
\hline wheatgrass) & -- & $\mathrm{X}$ & $\mathrm{X}$ & -- & $\mathrm{X}$ & $\mathrm{X}$ \\
\hline Agropyron cristatum $^{\mathrm{a}}$ (crested wheatgrass) & $\mathrm{X}$ & -- & -- & $\mathrm{X}$ & -- & -- \\
\hline Achillea millefolium (yarrow) & $\mathrm{X}$ & -- & -- & $\mathrm{X}$ & -- & -- \\
\hline Poa bulbosa ${ }^{\mathrm{a}}$ (bulbous bluegrass) & $\mathrm{X}$ & -- & 0.2 & $\mathrm{X}$ & -- & 6.7 \\
\hline Lactuca serriola ${ }^{\mathrm{a}}$ (prickly lettuce) & $\mathrm{X}$ & -- & -- & $\mathrm{X}$ & -- & -- \\
\hline $\begin{array}{l}\text { Erodium cicutarium }{ }^{\mathrm{a}} \text { (storksbill) } \\
\text { Sphaeralcea munroana (Munro's }\end{array}$ & -- & -- & 0.7 & -- & -- & 26.7 \\
\hline globemallow) & -- & -- & $\mathrm{X}$ & -- & -- & $\mathrm{X}$ \\
\hline Biotic crust & 0.0 & 0.0 & 0.0 & 0.0 & 0.0 & 0.0 \\
\hline Bare soil & 68.5 & 69.5 & 59.3 & 100.0 & 100.0 & 100.0 \\
\hline Litter & 0.3 & 28.0 & 30.8 & 100.0 & 100.0 & 100.0 \\
\hline Total canopy cover (litter not included) & 36.2 & 38.7 & 44.5 & & & \\
\hline \multicolumn{7}{|l|}{$\begin{array}{l}{ }^{\mathrm{a}} \text { Invasive species } \\
\mathrm{X}=\text { present but not counted in plot frames }\end{array}$} \\
\hline Total Invasive \% Cover & 10.5 & 20.8 & 33.0 & & & \\
\hline Total Native \% Cover & 25.7 & 17.8 & 11.7 & & & \\
\hline Change in Native \% Cover from 2009 & -8.9 & +4.3 & -9.5 & & & \\
\hline
\end{tabular}




\subsection{0-B/C SITES PLANTED IN 2008}

In December 2007 and January 2008 the 100-B-14, 118-B-1, and 118-C-1 sites were revegetated. These sites were remediated to meet the objectives for interim closure as established in the Remedial Design Report/Remedial Action Work Plan for the 100 Area (RDR/RAWP) (DOE-RL 2005a) and in the Interim Action Record of Decision for the 100-BC-1, 100-BC-2, 100-DR-1, 100-DR-2, 100-FR-1, 100-FR-2, 100-HR-1, 100-HR-2, 100-KR-1, 100-KR-2, 100-IU-2, 100-IU-6, and 200-CW-3 Operable Units, Hanford Site, Benton County, Washington (EPA 1999). These areas were broadcast seeded with a mixture of native grasses including Sandberg's bluegrass, Indian ricegrass, bluebunch wheatgrass, prairie junegrass, bottlebrush squirreltail, and needle-and-thread grass. In addition, $134 \mathrm{~kg} / \mathrm{ha}$ of Triple-16 fertilizer was added to the sites along with $4,480 \mathrm{~kg} / \mathrm{ha}$ of straw mulch that was spread and crimped into the soil surface. Sagebrush plugs were then planted into the seeded areas at 930 plants/ha.

\subsubsection{0-B-14 Pipelines}

Third-year monitoring was performed at the 100-B-14 site on April 27, 2010. Cheatgrass is now the dominant species with respect to canopy cover at this site, recorded at $15 \%$ canopy cover. Monitoring in 2009 showed Russian thistle as the dominant species, at 16\% cover, but that number reduced to only 6\% in 2010 (Table 18). Sandberg's bluegrass is becoming better established at the site, up to $8 \%$ cover from only $2 \%$ in 2009 . Overall, canopy cover remains low at this site, likely due to the extremely compacted conditions at the time of planting. If the grasses do not continue to grow and establish recruits, additional revegetation efforts may be required in order to meet restoration goals.

Two sagebrush transects were established on this site in May 2008. First-year survival counts in May 2009 determined shrub survival on transect T1 to be $7 \%$ and T2 to be $65 \%$. Monitoring in 2010 did not evaluate transect T1 due to low survival recorded in 2009; however, survival of planted shrubs on transect T2 was up slightly to $65.5 \%$ due to plants mistakenly counted as dead. In January 2010, 560 sagebrush seedlings were planted across the 100-B-14 site within areas where shrub distribution was visually sparse to compensate for low shrubs survival estimated on transect T1 in May 2009. 
Table 18. Percent Canopy Cover and Frequency of Occurrence at 100-B-14 in 2010.

\begin{tabular}{|c|c|c|}
\hline Species & \% Cover & $\%$ Freq of Occ \\
\hline Bromus tectorum $^{a}$ (cheatgrass) & 14.5 & 100.0 \\
\hline Poa sandbergii (Sandberg's bluegrass) & 7.8 & 100.0 \\
\hline Salsola kali ${ }^{a}$ (Russian thistle) & 6.1 & 92.0 \\
\hline Agropyron spicatum (bluebunch wheatgrass) & 3.0 & 44.0 \\
\hline Sisymbrium altissimum ${ }^{a}$ (tumble mustard) & 1.9 & 76.0 \\
\hline Chrysothamnus nauseosus (gray rabbitbrush) & 1.2 & 48.0 \\
\hline Holosteum umbellatum ${ }^{a}$ (jagged chickweed) & 1.1 & 44.0 \\
\hline Festuca octoflora (slender sixweeks) & 1.0 & 20.0 \\
\hline Epilobium paniculatum (tall willowherb) & 0.8 & 32.0 \\
\hline Draba verna $^{a}$ (spring whitlowgrass) & 0.7 & 28.0 \\
\hline Lactuca serriola $^{a}$ (prickly lettuce) & 0.5 & 20.0 \\
\hline Artemisia tridentata (big sagebrush) & 0.3 & 12.0 \\
\hline Chorispora tenella $^{a}$ (blue mustard) & 0.2 & 8.0 \\
\hline Poa bulbosa ${ }^{\text {a }}$ (bulbous bluegrass) & 0.2 & 8.0 \\
\hline Chaenactis douglasii (hoary falseyarrow) & 0.1 & 4.0 \\
\hline Tragopogon dubius $^{a}$ (yellow salsify) & 0.1 & 4.0 \\
\hline Ranunculus testiculatus $^{a}$ (bur buttercup) & 0.1 & 4.0 \\
\hline Achillea millefolium (yarrow) & $\mathrm{X}$ & $\mathrm{X}$ \\
\hline Agoseris heterophylla (mountain dandelion) & $\mathrm{X}$ & $\mathrm{X}$ \\
\hline Centaurea diffusa ${ }^{a}$ (diffuse knapweed) & $\mathrm{X}$ & $\mathrm{X}$ \\
\hline Machaeranthera canescens (hoary aster) & $\mathrm{X}$ & $\mathrm{X}$ \\
\hline Biotic crust & 0.0 & 0.0 \\
\hline Bare soil & 39.0 & 100.0 \\
\hline Litter & 51.0 & 100.0 \\
\hline Total canopy cover (litter not included) & 39.6 & \\
\hline \multicolumn{3}{|l|}{$\begin{array}{l}{ }^{\mathrm{a}} \text { Invasive species } \\
\mathrm{X}=\text { present but not counted in plot frames }\end{array}$} \\
\hline Total Invasive \% Cover & 25.4 & \\
\hline Total Native \% Cover & 14.2 & \\
\hline Change in Native \% Cover from 2009 & -1.4 & \\
\hline
\end{tabular}




\subsubsection{8-B-1 Burial Ground}

On May 11, 2010, third-year vegetation monitoring was performed at the 118-B-1 site (Figure 17). This site is separated into two monitoring areas, the soil staging area (SSA) and burial ground (BG), so that differences can be observed. The SSA has soil with a greater proportion of fine-grained material than the burial ground, and because the same planting treatment was performed on each site, the different soil types can be compared in terms of the vegetative community it supports over the 5 years of monitoring.

Russian thistle remained the dominant species on the burial ground, at 26\% canopy cover; however, Sandberg's bluegrass is becoming better established, having doubled its canopy cover to 20\% in 2010, over 2009 records (Table 19). Continued growth and recruitment of Sandberg's bluegrass, along with the other planted grasses observed on the site (i.e., bluebunch wheatgrass and bottlebrush squirreltail) is expected to result in the continued depression of the presence of Russian thistle on the site. The SSA has much less Russian thistle, at only 7\% cover, but maintains a good canopy of Sandberg's bluegrass, at 16\% cover. At this stage, the only significant difference between the sites is the amount of Russian thistle on the burial ground. Continued monitoring will show the succession paths of these sites will diverge.

Two sagebrush monitoring transects, one on the 118-B-1 Burial Ground and the other on the SSA east of the burial ground, were established in May 2008 and monitored in 2009 and 2010. Shrub survival estimates in September 2010 on the burial ground estimated shrub survival at $46 \%$ with $8.7 \%$ of those plants blooming last year. To compensate for reduced sagebrush survival on the burial ground, 1,350 sagebrush seedlings were planted on the burial ground within areas that had visually reduced shrubs densities in January 2010. Shrub survival on the SSA was estimated at $84.9 \%$ with $51 \%$ of those plants having bloomed last year. Sagebrush recruits were observed on the soil staging area along the monitoring transect.

Figure 17. 118-B-1 Burial Ground in 2010.

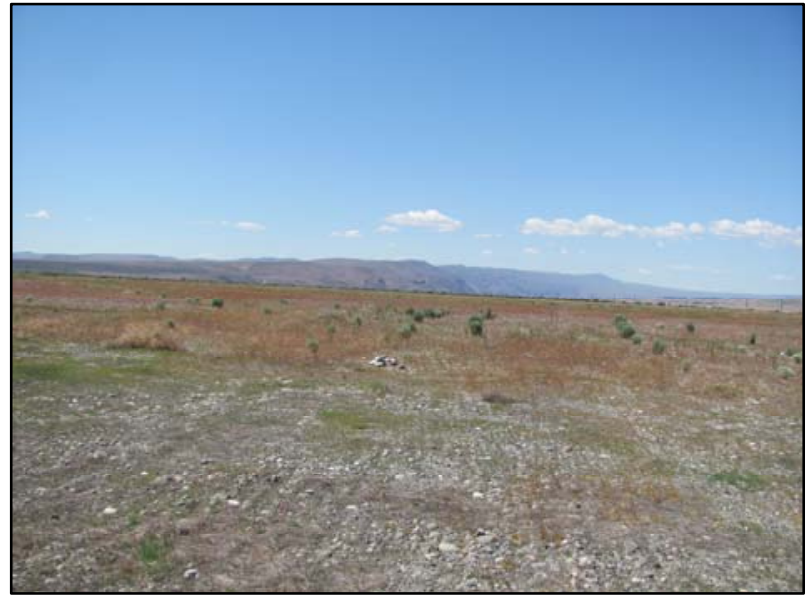

Burial ground looking west toward Vernita.

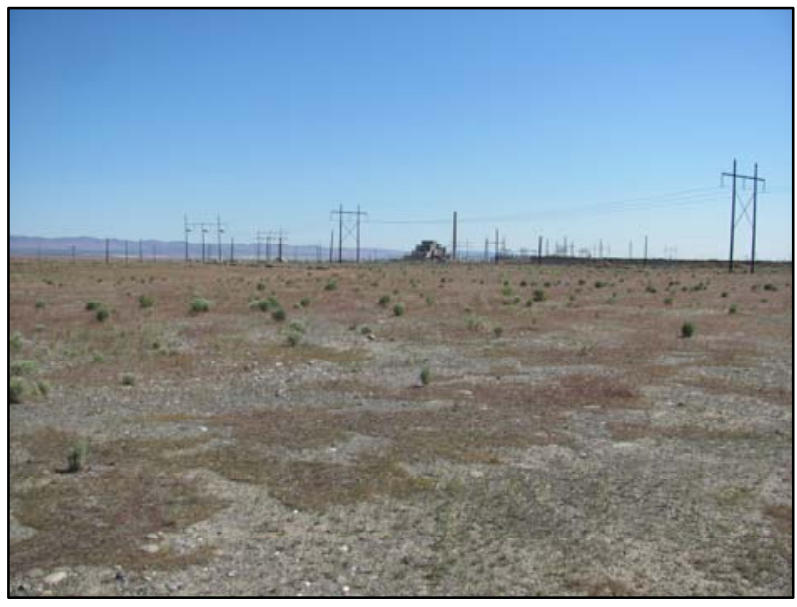

Soil staging area looking east toward 105-B. 
Table 19. Percent Canopy Cover and Frequency of Occurrence at 118-B-1 in 2010.

\begin{tabular}{|c|c|c|c|c|}
\hline Species & $\begin{array}{c}\text { \% Cover } \\
\text { BG } \\
\end{array}$ & $\begin{array}{c}\text { \% Cover } \\
\text { SSA } \\
\end{array}$ & $\begin{array}{c}\text { \% Freq of Occ } \\
\text { BG }\end{array}$ & $\begin{array}{c}\text { \% Freq of Occ } \\
\text { SSA } \\
\end{array}$ \\
\hline Salsola kali ${ }^{a}$ (Russian thistle) & 25.7 & 6.9 & 100.0 & 96.0 \\
\hline Poa sandbergii (Sandberg's bluegrass) & 19.5 & 16.3 & 96.0 & 100.0 \\
\hline Bromus tectorum $^{a}$ (cheatgrass) & 13.2 & 14.0 & 88.0 & 96.0 \\
\hline Festuca octoflora (slender sixweeks) & 3.2 & 0.7 & 16.0 & 28.0 \\
\hline Agropyron spicatum (bluebunch wheatgrass) & 2.3 & 1.9 & 36.0 & 56.0 \\
\hline Sisymbrium altissimum ${ }^{a}$ (tumble mustard) & 2.0 & 1.5 & 40.0 & 60.0 \\
\hline Chrysothamnus nauseosus (gray rabbitbrush) & 0.7 & 0.1 & 28.0 & 4.0 \\
\hline Poa bulbosa ${ }^{a}$ (bulbous bluegrass) & 0.7 & $\mathrm{X}$ & 8.0 & $\mathrm{X}$ \\
\hline Lactuca serriola $^{a}$ (prickly lettuce) & 0.3 & 0.7 & 12.0 & 28.0 \\
\hline Epilobium paniculatum (tall willowherb) & -- & 0.5 & -- & 20.0 \\
\hline Erodium cicutarium $^{a}$ (storksbill) & 0.4 & 0.3 & 16.0 & 12.0 \\
\hline Draba verna $^{a}$ (spring whitlowgrass) & 0.1 & 0.3 & 4.0 & 12.0 \\
\hline Artemisia tridentata (big sagebrush) & 0.1 & 0.3 & 4.0 & 12.0 \\
\hline Ambrosia acanthicarpa (bur ragweed) & -- & 0.3 & -- & 12.0 \\
\hline Centaurea diffusa ${ }^{a}$ (diffuse knapweed) & 0.2 & 0.1 & 8.0 & 4.0 \\
\hline Holosteum umbellatum ${ }^{a}$ (jagged chickweed) & 0.1 & 0.2 & 4.0 & 8.0 \\
\hline Achillea millefolium (yarrow) & $\mathrm{X}$ & 0.2 & $\mathrm{X}$ & 8.0 \\
\hline Sitanion hystrix (bottlebrush squirreltail) & 0.1 & -- & 4.0 & -- \\
\hline Melilotus alba ${ }^{a}$ (sweetclover) & -- & 0.1 & -- & 4.0 \\
\hline Microsteris gracilis (pink microsteris) & & 0.1 & & 4.0 \\
\hline Machaeranthera canescens (hoary aster) & $\mathrm{X}$ & -- & $\mathrm{X}$ & -- \\
\hline Layia glandulosa (white-daisy tidytips) & $\mathrm{X}$ & -- & $\mathrm{X}$ & -- \\
\hline Vulpia myuros ${ }^{a}$ (rat-tail fescue) & $\mathrm{X}$ & $\mathrm{X}$ & $\mathrm{X}$ & $\mathrm{X}$ \\
\hline Verbena bracteata ${ }^{\text {a }}$ (big-bract verbena) & -- & $\mathrm{X}$ & -- & $\mathrm{X}$ \\
\hline Sphaeralcea munroana (Munro's globemallow) & -- & $\mathrm{X}$ & -- & $\mathrm{X}$ \\
\hline Biotic crust & 0.0 & 0.0 & 0.0 & 0.0 \\
\hline Bare soil & 38.1 & 50.5 & 100.0 & 100.0 \\
\hline Litter & 55.0 & 43.7 & 100.0 & 100.0 \\
\hline Total canopy cover (litter not included) & 68.6 & 44.5 & & \\
\hline \multicolumn{5}{|l|}{$\begin{array}{l}\text { a Invasive species } \\
\mathrm{X}=\text { present but not counted in plot frames }\end{array}$} \\
\hline Total Invasive \% Cover & 42.7 & 24.1 & & \\
\hline Total Native \% Cover & 25.9 & 21.1 & & \\
\hline Change in Native \% Cover from 2009 & +4.9 & +5.1 & & \\
\hline
\end{tabular}




\subsubsection{8-C-1 Burial Ground}

Third-year monitoring was conducted at the 118-C-1 site on April 27, 2010 (Figure 18). Canopy cover remains extremely low for all species, with the dominant species (Sandberg's bluegrass) only recorded at $9 \%$ cover (Table 20 ). All other species were recorded at $3 \%$ cover or less. These conditions are likely due to the large cobbles and very small percentage of fine-grained soil present on the site. Rabbitbrush was recorded in $27 \%$ of the plot frames, due to natural recruitment from significant stands of rabbitbrush upwind of this area. Sagebrush monitoring showed only $24 \%$ of the shrubs surviving.

Figure 18. 118-C-1 Burial Ground in 2010.

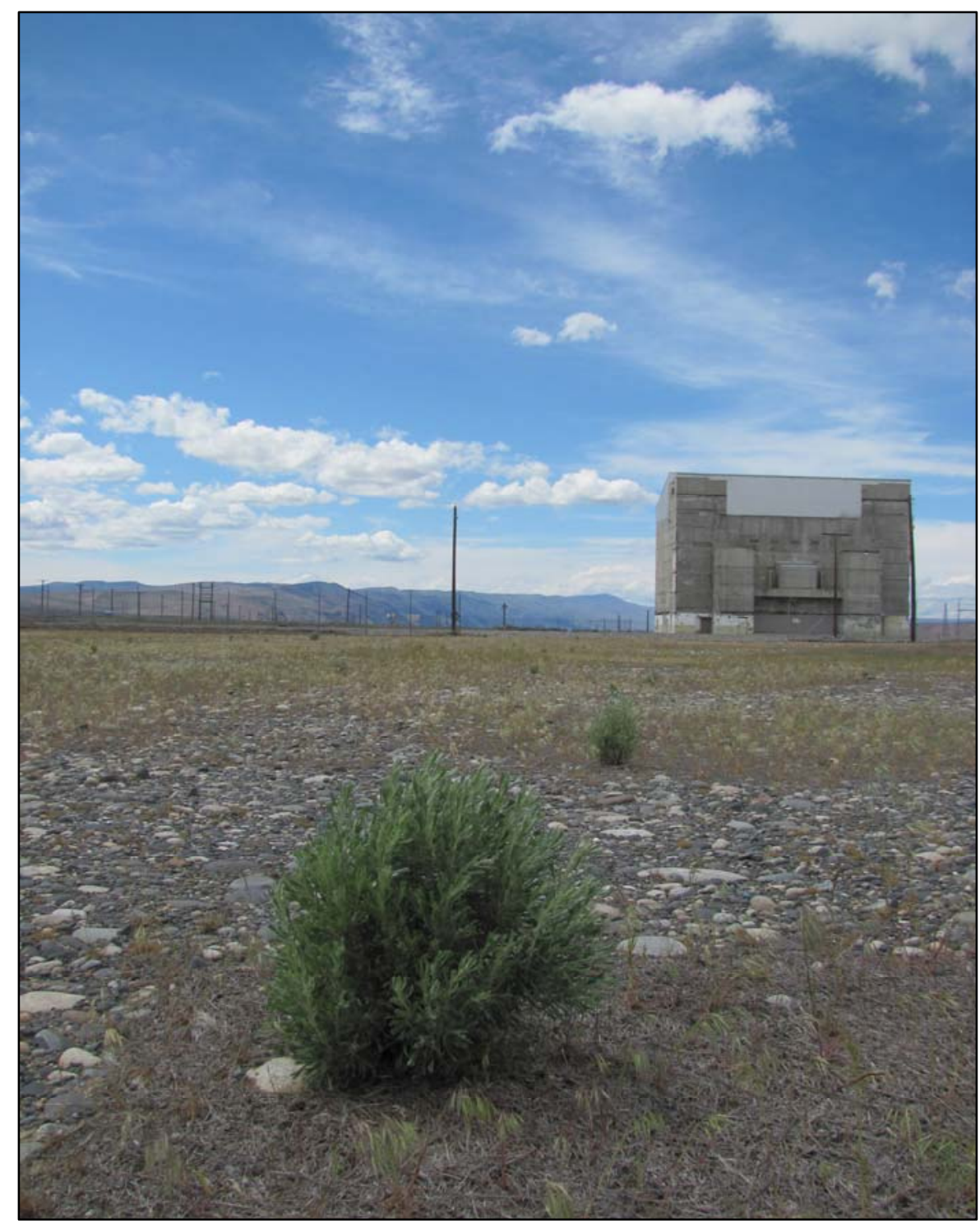

Planted sagebrush at the 118-C-1 site in 2010, looking west toward 105-C. 
Table 20. Percent Canopy Cover and Frequency of Occurrence at 118-C-1 in 2010.

\begin{tabular}{|c|c|c|}
\hline Species & \% Cover & \% Freq of Occ \\
\hline Poa sandbergii (Sandberg's bluegrass) & 8.8 & 93.3 \\
\hline Bromus tectorum ${ }^{\mathrm{a}}$ (cheatgrass) & 3.2 & 93.3 \\
\hline Salsola kali (Russian thistle) & 3.2 & 93.3 \\
\hline Agropyron spicatum (bluebunch wheatgrass) & 3.2 & 60.0 \\
\hline Chrysothamnus nauseosus (gray rabbitbrush) & 0.7 & 26.7 \\
\hline Sisymbrium altissimum ${ }^{\mathrm{a}}$ (tumble mustard) & 0.5 & 20.0 \\
\hline Holosteum umbellatum ${ }^{\mathrm{a}}$ (jagged chickweed) & 0.3 & 13.3 \\
\hline Draba verna ${ }^{\mathrm{a}}$ (spring whitlowgrass) & 0.3 & 13.3 \\
\hline Lactuca serriola $^{\mathrm{a}}$ (prickly lettuce) & 0.2 & 6.7 \\
\hline Poa bulbosa ${ }^{\mathrm{a}}$ (bulbous bluegrass) & 0.2 & 6.7 \\
\hline Festuca octoflora (slender sixweeks) & 0.2 & 6.7 \\
\hline Erigeron poliospermus (cushion fleabane) & $\mathrm{X}$ & $\mathrm{X}$ \\
\hline Centaurea diffusa ${ }^{\mathrm{a}}$ (diffuse knapweed) & $\mathrm{X}$ & $\mathrm{X}$ \\
\hline Tragopogon dubius ${ }^{\mathrm{a}}$ (yellow salsify) & $\mathrm{X}$ & $\mathrm{X}$ \\
\hline Artemisia tridentata (big sagebrush) & $\mathrm{X}$ & $\mathrm{X}$ \\
\hline Machaeranthera canescens (hoary aster) & $\mathrm{X}$ & $\mathrm{X}$ \\
\hline Biotic crust & 1.0 & 6.7 \\
\hline Bare soil & 57.5 & 93.3 \\
\hline Litter & 36.3 & 93.3 \\
\hline Total canopy cover (litter not included) & 21.0 & \\
\hline \multicolumn{3}{|l|}{$\begin{array}{l}\text { a Invasive species } \\
\mathrm{X}=\text { present but not counted in plot frames }\end{array}$} \\
\hline Total Invasive \% Cover & 7.8 & \\
\hline Total Native \% Cover & 12.8 & \\
\hline Change in Native \% Cover from 2009 & -0.9 & \\
\hline
\end{tabular}

\section{$3.8 \quad 100-B / C$ SITES PLANTED IN 2009}

In December 2009 through February 2010 the 100-B-27 and100-B-28 sites along with several other small sites were revegetated. These sites were remediated to meet the objectives for interim closure as established in the Remedial Design Report/Remedial Action Work Plan for the 100 Area (RDR/RAWP) (DOE-RL 2005a) and in the Interim Action Record of Decision for the 100-BC-1, 100-BC-2, 100-DR-1, 100-DR-2, 100-FR-1, 100-FR-2, 100-HR-1, 100-HR-2, 100-KR-1, 100-KR-2, 100-IU-2, 100-IU-6, and 200-CW-3 Operable Units, Hanford Site, Benton County, Washington (EPA 1999). These areas were broadcast seeded with a mixture of native grasses including Sandberg's bluegrass, Indian ricegrass, bluebunch wheatgrass, bottlebrush squirreltail, and needle-and-thread grass. In addition, $134 \mathrm{~kg} / \mathrm{ha}$ of Triple-16 fertilizer was added to the sites along with 4,480 kg/ha of straw mulch that was spread and crimped into the soil 
surface. Sagebrush and spiny hopsage plugs were then planted into the seeded areas at 1,235 plants/ha.

\subsubsection{0-B-28 Sodium Dichromate Transfer Pipeline}

The revegetation at the 100-B-28 site was monitored for the first time on May 25, 2010 (Figure 19). The site was dominated by native planted grasses, Sandberg's bluegrass, bluebunch wheatgrass, Indian ricegrass, needle-and-thread grass, and bottlebrush squirreltail grass with a collective cover of $39.5 \%$ and $100 \%$ frequency of occurrence in the plot frames (Table 21 ). Several introduced species including Russian thistle, blue mustard, hare barley, bur buttercup, and common groundsel were also recorded on the site. Most of these introduced species are not anticipated to persist. Ten native species were observed on the site, along with 12 non-native species. This number will be tracked to note changes in species diversity as the site matures.

A shrub monitoring transect was established this year to provide a reference for shrub survival across the plot. Planted sagebrush and spiny hopsage tubelings were recorded along the transect. Sixty-seven sagebrush and 36 hopsage were recorded along the 100-m-long transect. Sagebrush survival was recorded at $95.5 \%$, while hopsage was recorded at $97.2 \%$ alive during this first monitoring. Monitoring of these shrubs will continue for the next 4 years.

Figure 19. 100-B-28 Sodium Dichromate Transfer Pipeline in 2010.

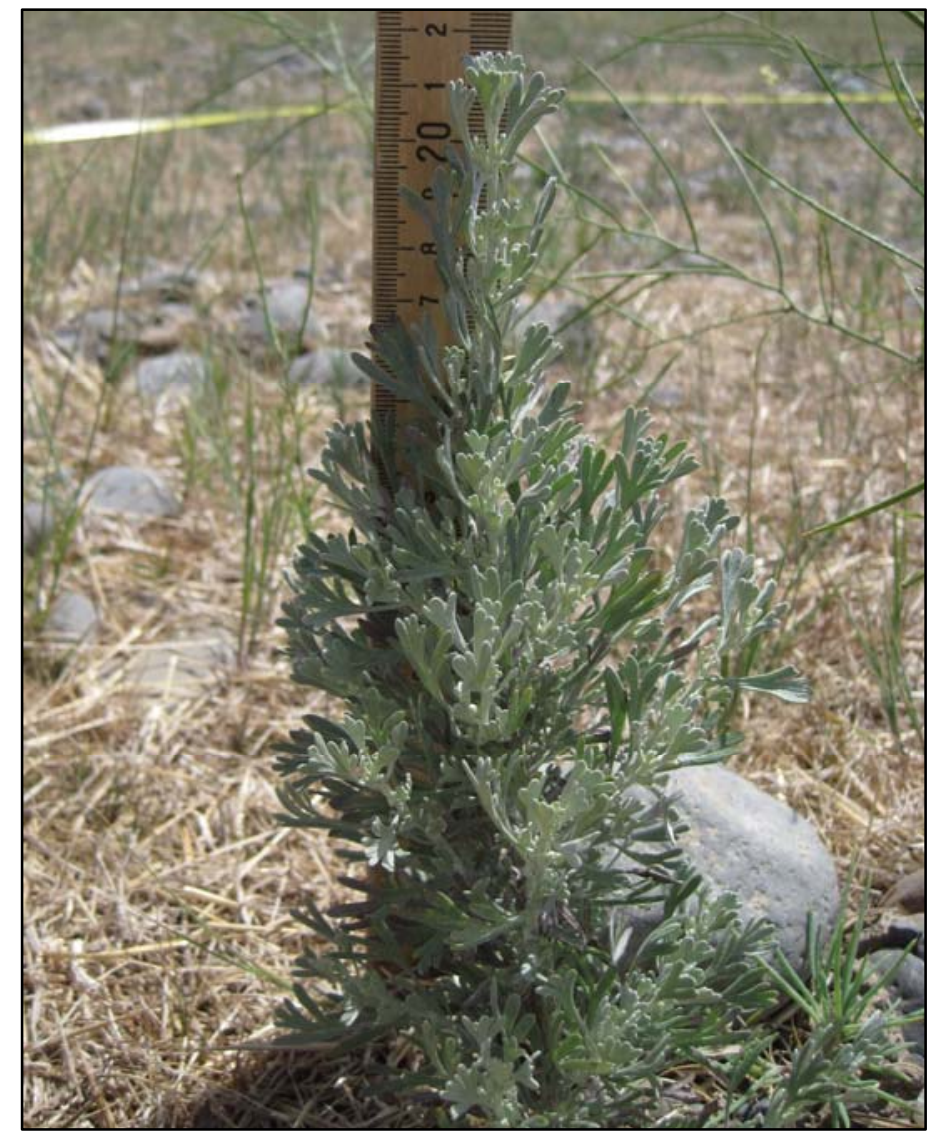

January 2010 planted sagebrush seedling, May 2010 at 100-B-28. 
Table 21. Percent Canopy Cover and Frequency of Occurrence at 100-B-28 in 2010.

\begin{tabular}{|c|c|c|}
\hline Species & \% Cover & $\%$ Freq of Occ \\
\hline Native grasses ${ }^{b}$ & 39.5 & 100.0 \\
\hline Bromus tectorum ${ }^{\text {a }}$ (cheatgrass) & 1.8 & 40.0 \\
\hline Salsola kali (Russian thistle) & 2.8 & 80.0 \\
\hline Sisymbrium altissimum ${ }^{\mathrm{a}}$ (tumble mustard) & 2.5 & 66.7 \\
\hline Chrysothamnus nauseosus (gray rabbitbrush) & 0.3 & 13.3 \\
\hline Artemisia tridentata (big sagebrush) & 0.3 & 13.3 \\
\hline Grayia spinosa (spiny hopsage) & 0.3 & 13.3 \\
\hline Chorispora tenella ${ }^{\mathrm{a}}$ (blue mustard) & 0.5 & 20.0 \\
\hline Holosteum umbellatum ${ }^{\mathrm{a}}$ (jagged chickweed) & 0.2 & 6.7 \\
\hline Hordeum leporinum ${ }^{\mathrm{a}}$ (hare barley) & 0.2 & 6.7 \\
\hline Centaurea diffusa ${ }^{\mathrm{a}}$ (diffuse knapweed) & 0.2 & 6.7 \\
\hline Ranunculus testiculatus ${ }^{\mathrm{a}}$ (bur buttercup) & 0.5 & 20.0 \\
\hline Draba verna $^{\mathrm{a}}$ (spring whitlowgrass) & 0.5 & 20.0 \\
\hline Lactuca serriola ${ }^{\mathrm{a}}$ (prickly lettuce) & 0.2 & 6.7 \\
\hline Agoseris heterophylla (mountain dandelion) & $\mathrm{X}$ & $\mathrm{X}$ \\
\hline Senecio vulgaris ${ }^{\mathrm{a}}$ (common groundsel) & $\mathrm{X}$ & $\mathrm{X}$ \\
\hline Festuca octoflora (slender sixweeks) & $\mathrm{X}$ & $\mathrm{X}$ \\
\hline Kochia scopari $^{\mathrm{a}}$ (kochia) & $\mathrm{X}$ & $\mathrm{X}$ \\
\hline Tragopogon dubius ${ }^{\text {a }}$ (yellow salsify) & $\mathrm{X}$ & $\mathrm{X}$ \\
\hline Biotic crust & 0.0 & 0.0 \\
\hline Bare soil & 22.2 & 93.3 \\
\hline Litter & 60.8 & 100.0 \\
\hline Total canopy cover (litter not included) & 49.8 & \\
\hline \multicolumn{3}{|c|}{$\begin{array}{l}\text { a Invasive species } \\
\text { b Includes Sandberg's bluegrass, bluebunch wheatgrass, thickspike wheatgrass, Indian ricegrass, needle-and-thread } \\
\text { grass, and prairie junegrass seedlings. }\end{array}$} \\
\hline \multicolumn{3}{|l|}{$\mathrm{X}=$ present but not counted in plot frames } \\
\hline Total Invasive \% Cover & 9.3 & \\
\hline Total Native \% Cover & 40.5 & \\
\hline
\end{tabular}

\subsubsection{0-B-27 Sodium Dichromate Spill}

The revegetation at the 100-B-27 site was monitored for the first time on May 25, 2010 (Figure 20). While conducting the initial vegetation monitoring on the site, seed germination on the western portion was significantly lower than the eastern portion. The eastern portion of the site was planted on February 10, 2010, while the western half of the site was planted on February 25, 2010. On September 1, 2010 the site was walked down again to evaluate the 
seeding success and it was decided that the western portion of the site would need to be rectified. That rectification has been scheduled for the fall of 2010. The vegetation data collected in May was across of the entire site, including the western portion that had considerably lower seedling emergence. The site was dominated by native planted bunchgrasses including Sandberg's bluegrass, bluebunch wheatgrass, Indian ricegrass, needle-and-thread grass, and bottlebrush squirreltail grass with a cover of $10.8 \%$ (Table 22). Of the species observed on the site, 9 were native and 10 were non-native.

An 82-m-long shrub monitoring transect was established on the eastern portion of the site. Fiftynine sagebrush seedlings planted along the transect were recorded, with first-year survival estimated at $96.6 \%$. Monitoring of these shrubs plus any shrubs replanted on the western portion of the site will be monitored for the next 4 years.

Figure 20. 100-B-27 Sodium Dichromate Spill Site in 2010.

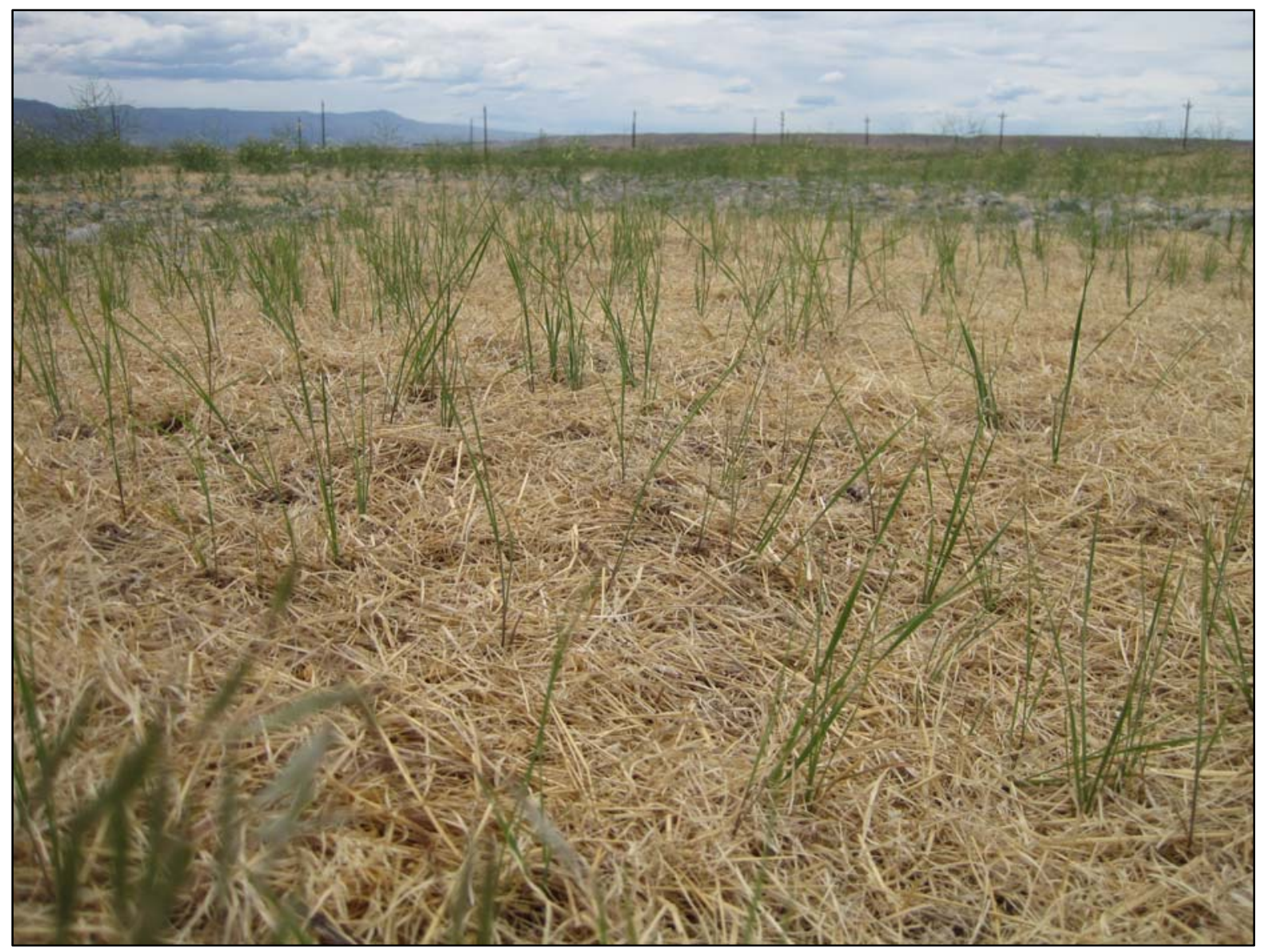

Planted grasses on the 100-B-27 site in May 2010, looking west toward Vernita. 
WCH-428

Rev. 0

Table 22. Percent Canopy Cover and Frequency of Occurrence at 100-B-27 in 2010.

\begin{tabular}{|c|c|c|}
\hline Species & \% Cover & $\%$ Freq of Occ \\
\hline Native grasses ${ }^{\mathrm{b}}$ & 10.8 & 100.0 \\
\hline Bromus tectorum ${ }^{\mathrm{a}}$ (cheatgrass) & 0.4 & 16.0 \\
\hline Salsola kali ${ }^{\mathrm{a}}$ (Russian thistle) & 1.5 & 40.0 \\
\hline Sisymbrium altissimum ${ }^{\mathrm{a}}$ (tumble mustard) & 0.7 & 28.0 \\
\hline Artemisia tridentata (big sagebrush) & 0.1 & 4.0 \\
\hline Melilotus alba (sweetclover) & 0.1 & 4.0 \\
\hline Chenopodium album ${ }^{\mathrm{a}}$ (lamb's quarters) & $\mathrm{X}$ & $\mathrm{X}$ \\
\hline Agoseris heterophylla (mountain dandelion) & $\mathrm{X}$ & $\mathrm{X}$ \\
\hline Bromus japonicus $s^{\mathrm{a}}$ (Japenese brome) & $\mathrm{X}$ & $\mathrm{X}$ \\
\hline Lactuca serriola ${ }^{a}$ (prickly lettuce) & $\mathrm{X}$ & $\mathrm{X}$ \\
\hline Hordeum leporinum ${ }^{\mathrm{a}}$ (hare barley) & $\mathrm{X}$ & $\mathrm{X}$ \\
\hline Chorispora tenella ${ }^{\mathrm{a}}$ (blue mustard) & $\mathrm{X}$ & $\mathrm{X}$ \\
\hline Grayia spinosa (spiny hopsage) & $\mathrm{X}$ & $\mathrm{X}$ \\
\hline Centaurea diffusa (diffuse knapweed) & $\mathrm{X}$ & $\mathrm{X}$ \\
\hline Amsinckia lycopsoides (tarweed fiddleneck) & $\mathrm{X}$ & $\mathrm{X}$ \\
\hline Biotic crust & 0.0 & 0.0 \\
\hline Bare soil & 26.5 & 92.0 \\
\hline Litter & 57.8 & 100.0 \\
\hline Total canopy cover (litter not included) & 13.6 & \\
\hline \multicolumn{3}{|c|}{$\begin{array}{l}\text { a Invasive species } \\
\text { b Includes Sandberg's bluegrass, bluebunch wheatgrass, thickspike wheatgrass, Indian ricegrass, needle-and-thread grass, } \\
\text { and prairie junegrass seedlings. }\end{array}$} \\
\hline \multicolumn{3}{|l|}{$X=$ present but not counted in plot frames } \\
\hline Total Invasive \% Cover & 2.7 & \\
\hline Total Native \% Cover & 10.9 & \\
\hline
\end{tabular}




\subsection{HORSESHOE LANDFILL}

The Horseshoe Landfill is located on the Fitzner-Eberhardt Arid Lands Ecology Reserve and served as a military landfill for the nearby Nike missile base. The Horseshoe Landfill is a former CERCLA waste site that was part of the 1100-IU-1 Operable Unit. In 1994, approximately $1,911 \mathrm{~m}^{3}$ of soil contaminated with DDT and other hazardous material and debris were excavated from the landfill (DOE-RL 1996) It was remediated as part of the activities outlined in the ROD for the 1100 Area National Priorities List site (EPA 1993) and was removed from the National Priorities List in 1996 (61 Federal Register 51019). The primary contaminant of concern at this site was dichlorodiphenyltrichloroethane (DDT).

Post-closure biota sampling and soil sampling performed between 1998 and 2003 at the site indicated that concentrations of DDT and its breakdown products dichlorodiphenyldichloroethylene (DDE) and dichlorodiphenyldichloroethane (DDD) were present in low concentrations within the landfill surface soils exceeding the 1994 cleanup criteria of $1 \mathrm{mg} / \mathrm{kg}$ (DOE-RL 2002).

The May 2005 remediation of the Horseshoe Landfill was initiated in response to post-closure surface soil sampling performed between 1998 and 2003 that indicated the presence of residual DDT contamination exceeding the cleanup criteria of $1 \mathrm{mg} / \mathrm{kg}$ that was established for the original 1994 cleanup activities (EPA 1993). The original cleanup level for DDT was based on Washington Administrative Code (WAC) 173-340-740, Method A. However, for this additional remediation, the DDT was removed to meet the more stringent ecological soil indicator concentration for protection of terrestrial plants and animals for total DDT/DDE/DDD of $0.75 \mathrm{mg} / \mathrm{kg}$ (WAC 173-340, Table 749-3).

Remediation of the Horseshoe Landfill was initiated on May 17, 2005, and completed on August 24, 2005. Approximately 4,935 bulk cubic meters (bcm) of contaminated soil was excavated from the landfill and disposed of at the ERDF. On the return trip, the remediation contractor hauled clean soil (excavated during ERDF construction) back to the Horseshoe Landfill and stockpiled it for use as backfill material. Prior to stockpiling, the top $46 \mathrm{~cm}$ of native soil was pushed to the side for redistribution across the soil staging area upon completion of the project.

The Horseshoe Landfill (HSLF) and clean soil staging area (SSA) were revegetated with native species the first week of February 2006. Figure 21 shows photos takend during planting at the site. In preparation for broadcast seeding the area, the top $23 \mathrm{~cm}$ of soil was loosened with a spring tooth implement (Figure 21). The Horseshoe Landfill and soil staging area were seeded with Sandberg's bluegrass, Indian ricegrass, bluebunch wheatgrass, and needle-and-thread grass. The areas were fertilized with triple-16 fertilizer and treated with polyacrylamide to facilitate successful germination and to reduce wind erosion. The seeded areas were mulched with grass straw and crimped into the soil to prevent the straw from blowing away. The landfill and soil staging area were planted with sagebrush seedlings propagated by two native plant nurseries from seed collected on the Hanford Site and grown in 10-in. containers. 
The landfill and soil staging area are being monitored separately as the landfill was backfilled with Rupert sand imported from the 200 West Area while the soil staging area has Ritzville siltloam that is native to this location.

Fifth-year vegetation and sagebrush monitoring was conducted at the HSLF site on June 28, 2010 (Figure 22). Both areas have been successfully revegetated and are dominated by native species. Sandberg's bluegrass is the dominant species on both sites, followed by bluebunch wheatgrass. The combined canopy cover of these two species account for a majority of the total ground cover seen at the sites. Beyond the planted grasses, many native forb species have become established naturally at these areas. Overall, a total of 25 native species were observed on the two sites, with only 9 non-native species recorded (Table 23). Likely due to this high level of native occupancy, canopy cover of cheatgrass is extremely low at both sites, at only $3 \%$.

Sagebrush planting was extremely successful at both of these areas. The two transects at the HSLF showed $62 \%$ and $70 \%$ survival, while the two transects at the SSA showed $86 \%$ and $54 \%$ survival. In addition to the high survival rates, 22\% of the shrubs on Transect 1 and 36\% on Transect 2 at the HSLF were observed to have bloomed in the previous year. Sagebrush seedlings blanket the area surrounding these shrubs. Data showed $99 \%$ and $92 \%$ of the shrubs blooming on the two transects at the SSA, also with many recruits. Recruits have been recorded at these sites for several years, and well established recruits can be observed across the sites. Due to the high survival rates, and successful recruitment, this site has well exceeded restoration goals for shrub establishment. 
Figure 21. Revegetation of the Horseshoe Landfill and Soil Staging Area.

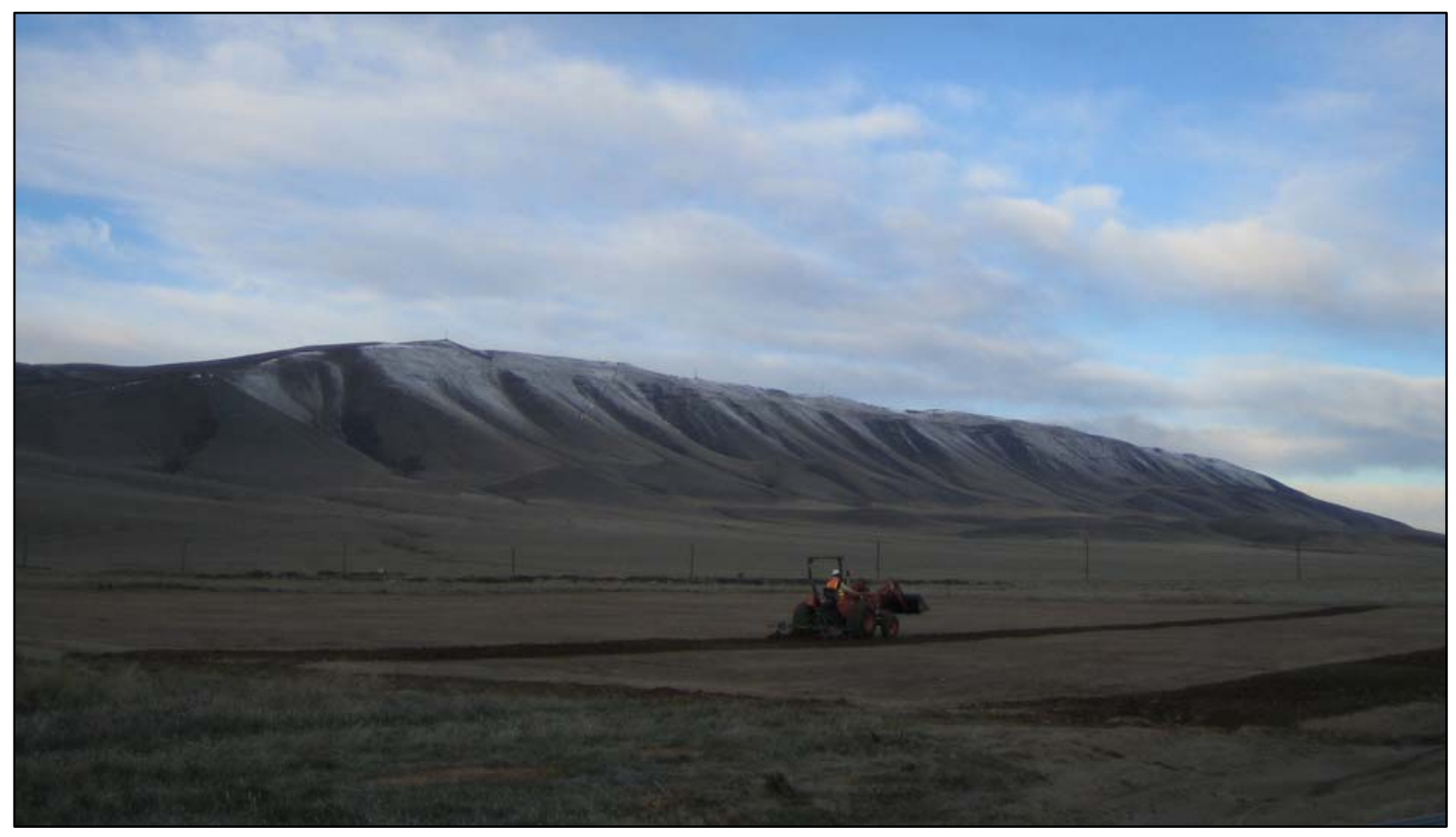

Soil preparation, February 2006.

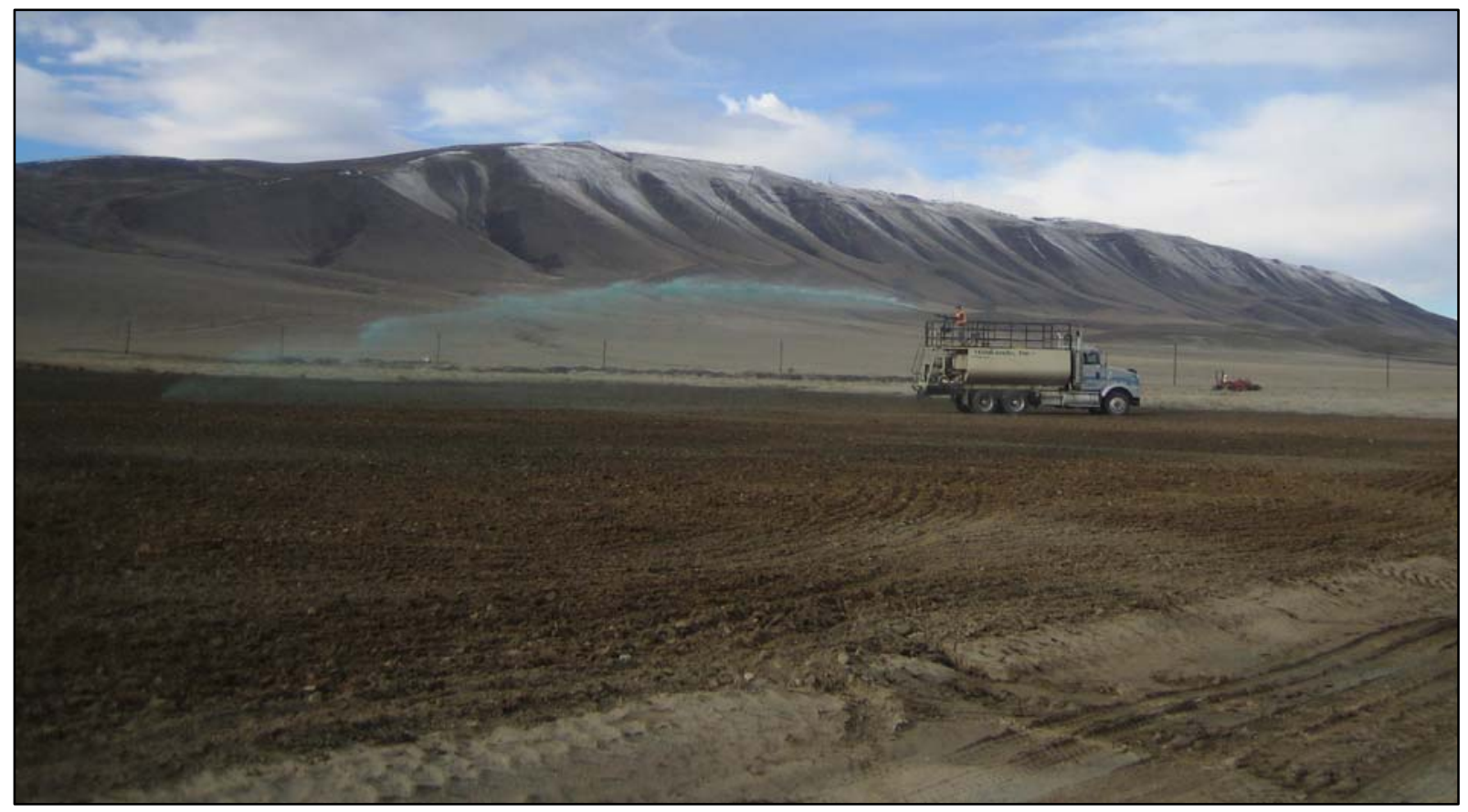

Seeding, February 2006. 
Figure 22. Horseshoe Landfill and Soil Staging Area in 2010.

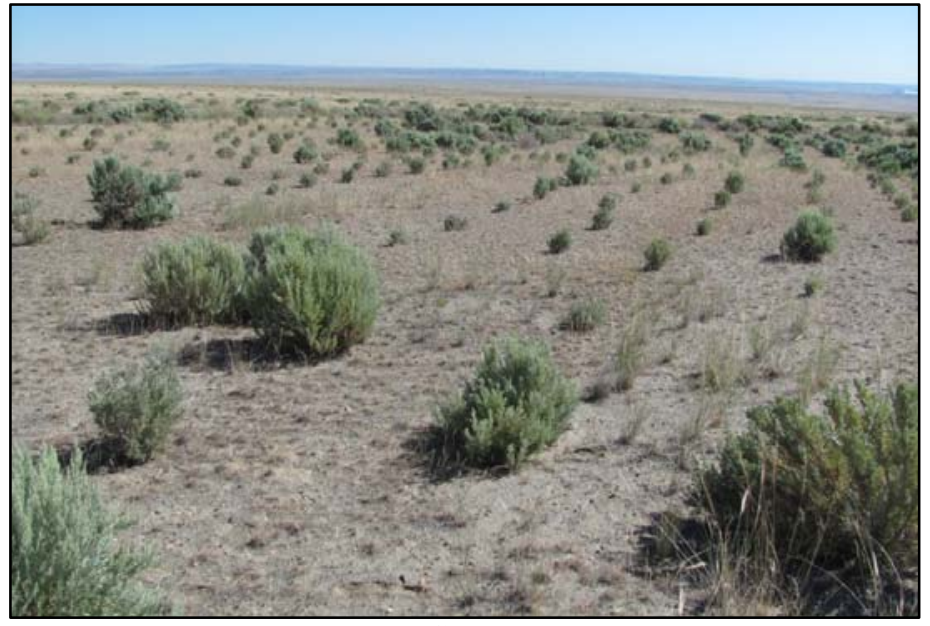

Horseshoe landfill, June 2010.

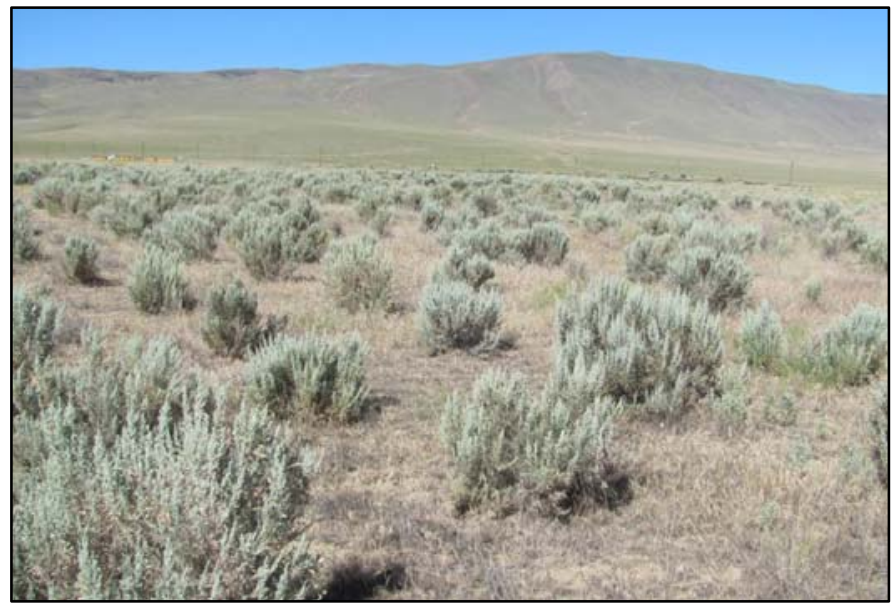

Soil staging area, June 2010.

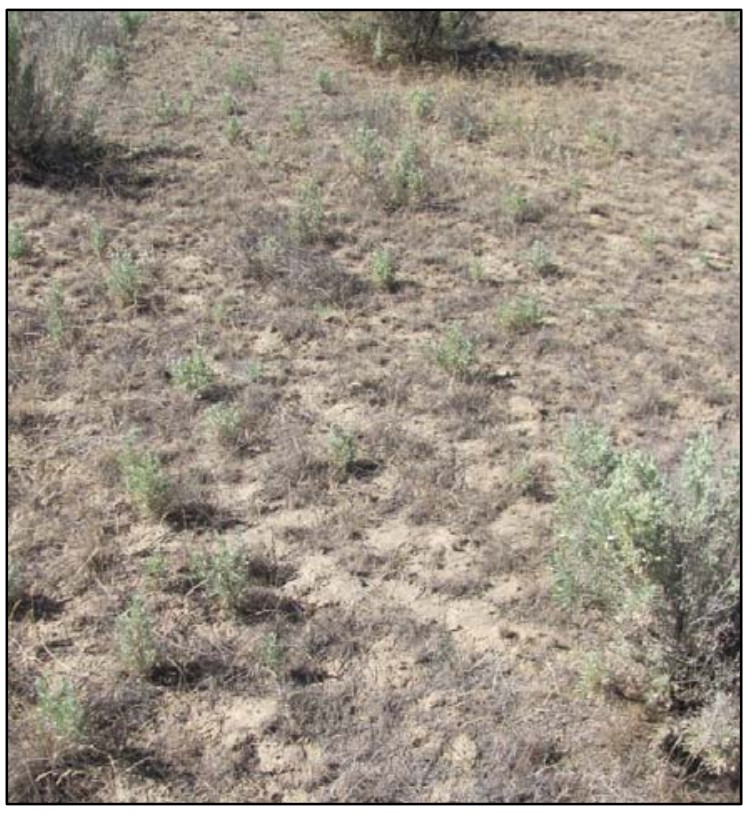

Volunteer sagebrush seedlings on the soil staging area, June 2010. 
WCH-428

Rev. 0

Table 23. Percent Canopy Cover and Frequency of Occurrence at Horseshoe Landfill and Soil Staging Area in 2010.

\begin{tabular}{|c|c|c|c|c|}
\hline Species & $\begin{array}{c}\text { HSLF } \\
\text { \% Cover }\end{array}$ & $\begin{array}{c}\text { SSA } \\
\text { \% Cover } \\
\end{array}$ & $\begin{array}{c}\text { HSLF } \\
\% \text { Freq of Occ }\end{array}$ & $\begin{array}{c}\text { SSA } \\
\% \text { Freq of Occ } \\
\end{array}$ \\
\hline Poa sandbergii (Sandberg's bluegrass) & 22.3 & 38.5 & 100.0 & 100.0 \\
\hline Agropyron spicatum (bluebunch wheatgrass) & 3.3 & 6.2 & 66.7 & 26.7 \\
\hline Artemisia tridentata (big sagebrush) & 2.5 & 5.5 & 66.7 & 60 \\
\hline Bromus tectorum ${ }^{\text {a }}$ (cheatgrass) & 3.2 & 3.3 & 93.3 & 66.7 \\
\hline Chrysothamnus nauseosus (gray rabbitbrush) & 1.8 & -- & 73.3 & -- \\
\hline Machaeranthera canescens (hoary aster) & 1.3 & 0.2 & 53.3 & 6.7 \\
\hline Oryzopsis hymenoides (Indian ricegrass) & 1.3 & 0.2 & 53.3 & 6.7 \\
\hline Sitanion hystrix (bottlebrush squirreltail) & 1.0 & 0.5 & 40.0 & 20 \\
\hline Tragopogon dubius ${ }^{\mathrm{a}}$ (yellow salsify) & 0.2 & 0.8 & 6.7 & 33.3 \\
\hline Sisymbrium altissimum ${ }^{\mathrm{a}}$ (tumble mustard) & $\mathrm{X}$ & 0.7 & $\mathrm{X}$ & 26.7 \\
\hline Salsola kali (Russian thistle) & 0.7 & 0.3 & 26.7 & 13.3 \\
\hline Epilobium paniculatum (tall willowherb) & 0.7 & $\mathrm{X}$ & 26.7 & $\mathrm{X}$ \\
\hline Amsinckia lycopsoides (tarweed fiddleneck) & -- & 0.5 & -- & 20 \\
\hline Lupinus leucophyllus (velvet lupine) & $\mathrm{X}$ & 0.3 & $\mathrm{X}$ & 13.3 \\
\hline Festuca octoflora (slender sixweeks) & 0.2 & $\mathrm{X}$ & 6.7 & $\mathrm{X}$ \\
\hline Melilotus alba ${ }^{\mathrm{a}}$ (sweetclover) & 0.2 & -- & 6.7 & -- \\
\hline Draba verna $^{\text {a }}$ (spring whitlowgrass) & 0.2 & -- & 6.7 & -- \\
\hline Erigeron piperianus (Piper's daisy) & 0.2 & -- & 6.7 & -- \\
\hline Lactuca serriola $^{\text {a }}$ (prickly lettuce) & $\mathrm{X}$ & 0.2 & $\mathrm{X}$ & $6 . .7$ \\
\hline Crepis atrabarba (slender hawksbeard) & -- & 0.2 & -- & 6.7 \\
\hline Conyza canadensis (mares tail) & $\mathrm{X}$ & -- & $\mathrm{X}$ & -- \\
\hline Holosteum umbellatuma (jagged chickweed) & -- & $\mathrm{X}$ & -- & $\mathrm{X}$ \\
\hline Achillea millefolium (yarrow) & $\mathrm{X}$ & $\mathrm{X}$ & $\mathrm{X}$ & $\mathrm{X}$ \\
\hline 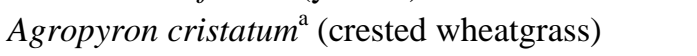 & $\mathrm{X}$ & -- & $\mathrm{X}$ & -- \\
\hline Linum perenne (wild blueflax) & $\mathrm{X}$ & -- & $\mathrm{X}$ & -- \\
\hline Erigeron filifolius (threadleaf fleabane) & $\mathrm{X}$ & $\mathrm{X}$ & $\mathrm{X}$ & $\mathrm{X}$ \\
\hline Ambrosia acanthicarpa (bur ragweed) & $\mathrm{X}$ & -- & $\mathrm{X}$ & -- \\
\hline Helianthus cusickii (Cusick's sunflower) & $\mathrm{X}$ & -- & $\mathrm{X}$ & -- \\
\hline Bromus japonicus $^{\text {a }}$ (Japanese brome) & $\mathrm{X}$ & -- & $\mathrm{X}$ & -- \\
\hline Agoseris heterophylla (mountain dandelion) & $\mathrm{X}$ & -- & $\mathrm{X}$ & -- \\
\hline Astragalus sclerocarpus (stalked pod milkvetch) & $\mathrm{X}$ & -- & $\mathrm{X}$ & -- \\
\hline Balsamorhiza careyana (Carey's balsamroot) & $\mathrm{X}$ & $\mathrm{X}$ & $\mathrm{X}$ & $\mathrm{X}$ \\
\hline Lomatium grayi (Gray's desertparsley) & -- & $\mathrm{X}$ & - & $\mathrm{X}$ \\
\hline Phlox longifolia (longleaf phlox) & -- & $\mathrm{X}$ & -- & $\mathrm{X}$ \\
\hline Crust & 7.5 & 0.2 & 100.0 & 6.7 \\
\hline Soil & 74.3 & 0.3 & 100.0 & 13.3 \\
\hline Litter & 9.0 & 24.2 & 100.0 & 86.7 \\
\hline Total canopy cover (litter not included) & 39.0 & 57.5 & & \\
\hline \multicolumn{5}{|l|}{$\begin{array}{l}{ }^{\mathrm{a}} \text { Invasive species } \\
\mathrm{X}=\text { present but not counted in plot frames }\end{array}$} \\
\hline Total Invasive \% Cover & 4.3 & 5.3 & & \\
\hline Total Native \% Cover & 34.7 & 52.2 & & \\
\hline Change in Native \% Cover from 2009 & -15.4 & -10.4 & & \\
\hline
\end{tabular}




\subsection{AREA SITES}

Remedial action of waste sites 600-111 and 600-149:2 within the 100-IU-2 Operable Unit were initiated in 2008. The remedial action objectives and goals were established by the U.S. Environmental Protection Agency and the Washington State Department of Ecology, in concurrence with the U. S. Department of Energy, Richland Operations Office and documented in the Interim Action Record of Decision for the 100-BC-1, 100-BC-2, 100-DR-1, 100-DR-2, 100-FR-1, 100-FR-2, 100-HR-1, 100-HR-2, 100-KR-1, 100-KR-2, 100-IU-2, 100-IU-6, and 200-CW-3 Operable Units, Hanford Site, Benton County, Washington (EPA 1999). The sites were excavated to the extent required to meet specified soil cleanup levels, the contaminated materials were disposed of at the ERDF, and the sites were backfilled and contoured to match the adjacent area in December 2008. These areas were broadcast seeded with a mixture of native grasses including Sandberg's bluegrass, Indian ricegrass, bluebunch wheatgrass, prairie junegrass, bottlebrush squirreltail, and needle-and-thread grass. In addition, $134 \mathrm{~kg} / \mathrm{ha}$ of Triple16 fertilizer was added to the sites along with $4,480 \mathrm{~kg} / \mathrm{ha}$ of straw mulch that was spread and crimped into the soil surface. Sagebrush and bitterbrush plugs were then planted into the seeded areas at 1,235 plants/ha.

\subsection{0-111 CRITICALITY MASS LABORATORY}

The revegetation at the 600-111 site was monitored for the second year on June 8, 2010 (Figure 23). As expected, Russian thistle and tumble mustard covers dropped from 34\% to 3.2\% and $8.2 \%$ to $4.0 \%$, respectively, with a total decline of $31.8 \%$ for invasive species cover (Table 24). At the same time, native grass cover also dropped from $29.4 \%$ to $14.8 \%$ cover in 2010, but worth noting that native grasses were recorded in $100 \%$ of the plot frames. Twenty-six species were observed on the site, this is seven more species than was observed in 2009. Of those plants, 14 were native and 12 were non-natives.

The shrub monitoring transect established in 2009 was evaluated for survival during the June site visit. Of the sagebrush and hopsage monitored, survival was calculated to be $23 \%$ and $93 \%$. Monitoring of these shrubs will continue for the next 4 years. 
Figure 23. 600-111 Criticality Mass Laboratory in 2010.

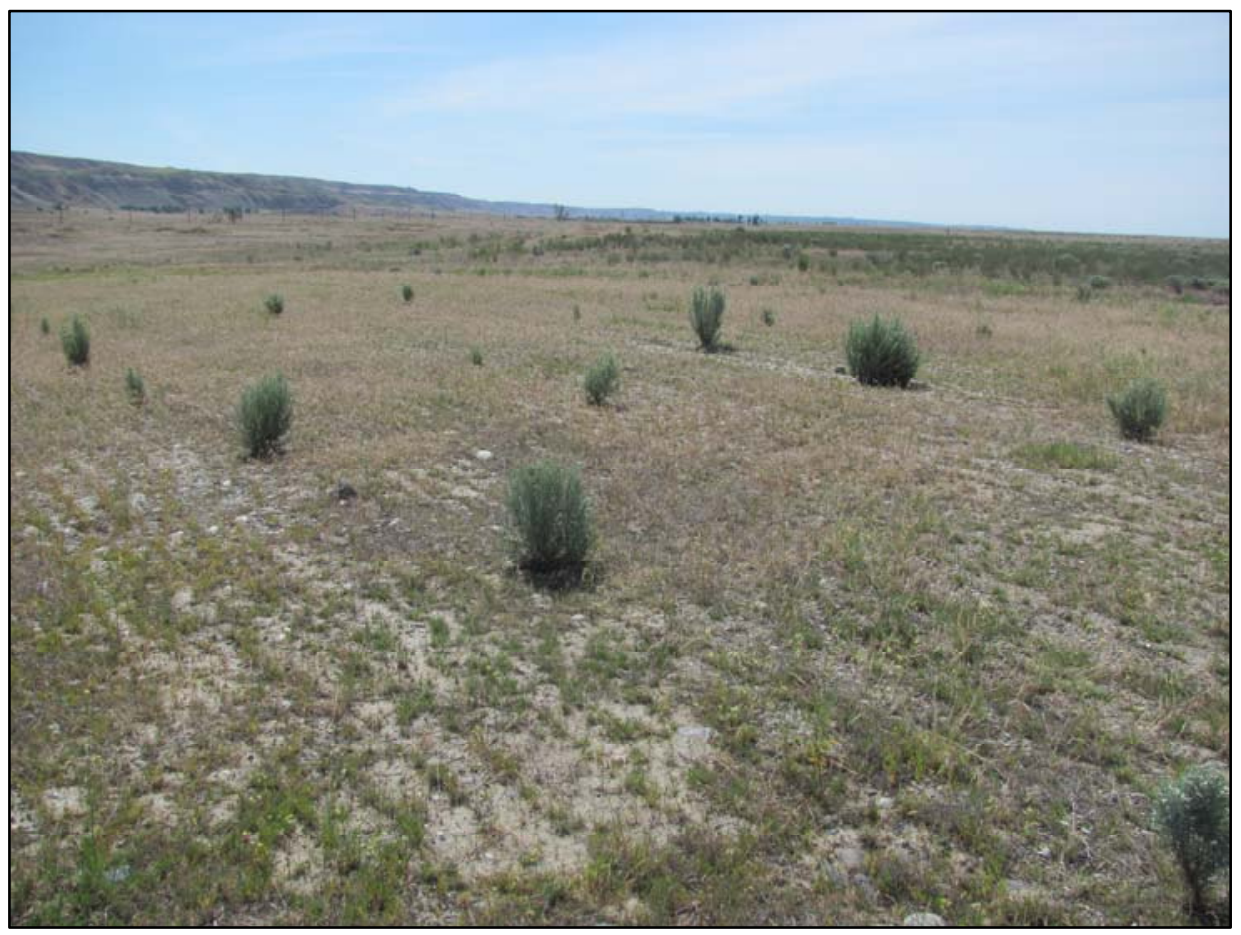

Planted sagebrush and grasses at the 600-111 site during 2010 monitoring.

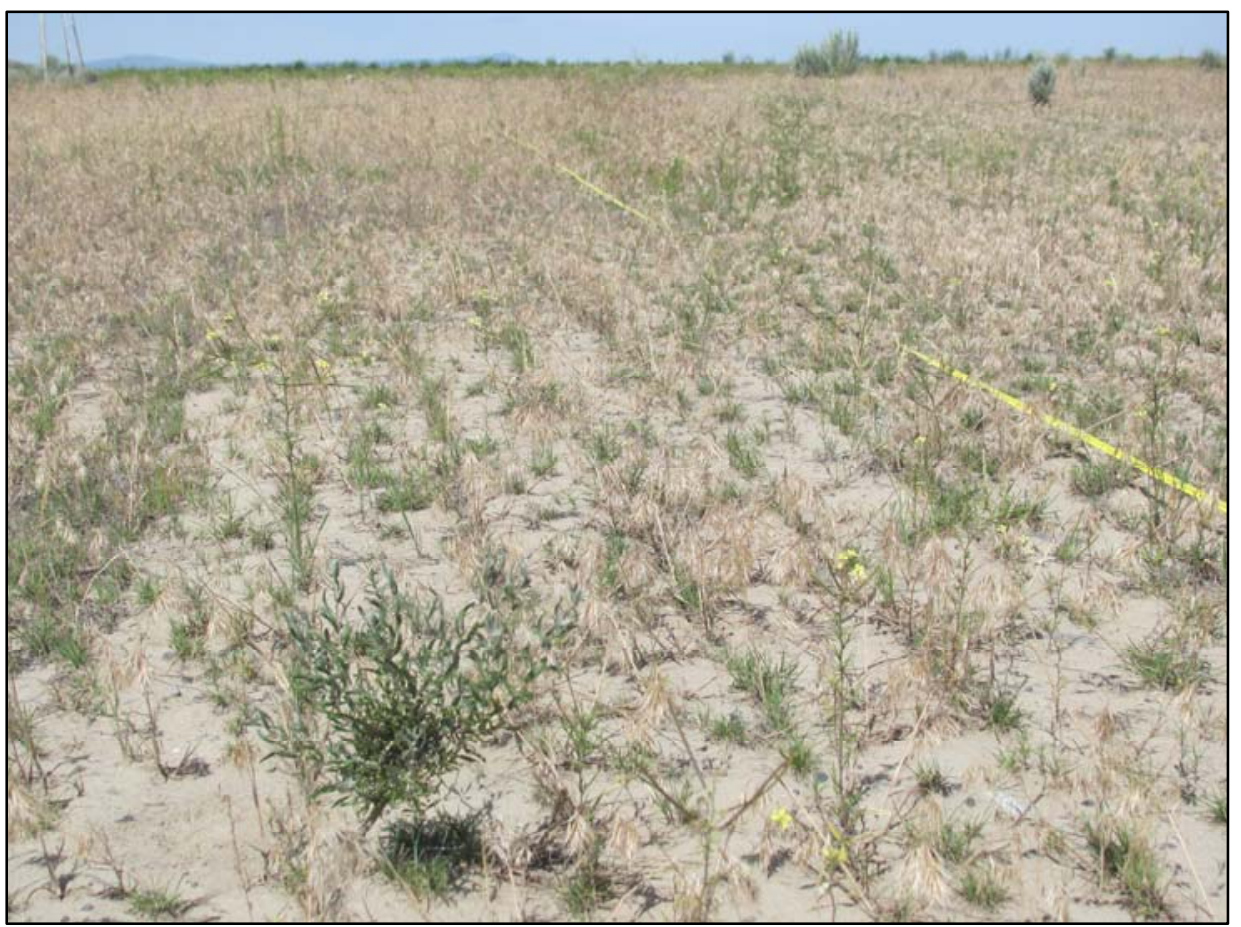

Planted hopsage and grasses at the 600-111 site during 2010 monitoring. 
Table 24. Percent Canopy Cover and Frequency of Occurrence at 600-111 in 2010.

\begin{tabular}{|c|c|c|}
\hline Species & \% Cover & $\%$ Freq of Occ \\
\hline Bromus tectorum ${ }^{\text {a }}$ (cheatgrass) & 10.7 & 100.0 \\
\hline Poa scabrella (pine bluegrass) & 8.7 & 80.0 \\
\hline Sisymbrium altissimum ${ }^{\mathrm{a}}$ (tumble mustard) & 4.0 & 93.3 \\
\hline Poa sandbergii (Sandberg's bluegrass) & 3.3 & 100.0 \\
\hline Salsola kali (Russian thistle) & 3.2 & 93.3 \\
\hline Sitanion hystrix (bottlebrush squirreltail) & 1.3 & 53.3 \\
\hline Poa bulbosa $a^{\mathrm{a}}$ (bulbous bluegrass) & 1.2 & 13.3 \\
\hline Holosteum umbellatum ${ }^{\mathrm{a}}$ (jagged chickweed) & 1.0 & 40.0 \\
\hline Agropyron spicatum (bluebunch wheatgrass) & 0.8 & 33.3 \\
\hline Stipa comata (needle-and-thread grass) & 0.7 & 26.7 \\
\hline Draba verna $^{\mathrm{a}}$ (spring whitlowgrass) & 0.5 & 20.0 \\
\hline Achillea millefolium (yarrow) & 0.5 & 20.0 \\
\hline Descurainia pinnata (western tansymustard) & 0.5 & 20.0 \\
\hline Gilia leptomeria (Great Basin gilia) & 0.5 & 20.0 \\
\hline Agropyron dasytachyum (thickspike wheatgrass) & 0.3 & 13.3 \\
\hline Lactuca serriola ${ }^{\mathrm{a}}$ (prickly lettuce) & 0.2 & 6.7 \\
\hline Oryzopsis hymenoides (Indian ricegrass) & 0.2 & 6.7 \\
\hline Tragopogon dubius ${ }^{\text {a }}$ (yellow salsify) & 0.2 & 6.7 \\
\hline Lepidium perfoliatum ${ }^{\mathrm{a}}$ (clasping pepperweed) & 0.2 & 6.7 \\
\hline Agropyron cristatum ${ }^{\mathrm{a}}$ (crested wheatgrass) & $\mathrm{X}$ & $\mathrm{X}$ \\
\hline Vicia cracca $^{\mathrm{a}}$ (bird vetch) & $\mathrm{X}$ & $\mathrm{X}$ \\
\hline Chorispora tenella ${ }^{\text {a }}$ (blue mustard) & $\mathrm{X}$ & $\mathrm{X}$ \\
\hline Machaeranthera canescens (hoary aster) & $\mathrm{X}$ & $\mathrm{X}$ \\
\hline Grayia spinosa (spiny hopsage) & $\mathrm{X}$ & $\mathrm{X}$ \\
\hline Amsinckia lycopsoides (tarweed fiddleneck) & $\mathrm{X}$ & $\mathrm{X}$ \\
\hline Artemisia tridentata (big sagebrush) & $\mathrm{X}$ & $\mathrm{X}$ \\
\hline Crust & 0.0 & 0.0 \\
\hline Soil & 39.0 & 100.0 \\
\hline Litter & 41.2 & 100.0 \\
\hline Total canopy cover (litter not included) & 37.7 & \\
\hline \multicolumn{3}{|l|}{$\begin{array}{l}{ }^{\mathrm{a}} \text { Invasive species } \\
\mathrm{X}=\text { present but not counted in plot frames }\end{array}$} \\
\hline Total Invasive \% Cover & 19.5 & \\
\hline Total Native \% Cover & 18.3 & \\
\hline Change in Native \% Cover from 2009 & -13.2 & \\
\hline
\end{tabular}




\subsection{0-149:2 SMALL ARMS RANGE}

The revegetated 600-149:2 site was monitored for the second time on June 8, 2010 (Figure 24). As expected the native planted grasses bluebunch wheatgrass and Sandberg's bluegrass covers that dominated the site during the first monitoring period shortly after the site was seeded decreased from $30 \%$ and $18 \%$ to $1.5 \%$ and $6 \%$ with $60 \%$ and $100 \%$ frequency of occurrence within the plot frames, respectively (Table 25). Tumble mustard cover remained consistent at $4 \%$ cover with Russian thistle and cheatgrass covers showed an increase of $12 \%$ and $9 \%$. Fifteen native species were observed on the site this year, nine more than were observed on the site in 2009. Sagebrush recruitments were also observed on the site, not from the seedlings planted as they are not yet blooming but from the shrubs surrounding the site.

Figure 24. 600-149:2 Small Arms Range in 2010.

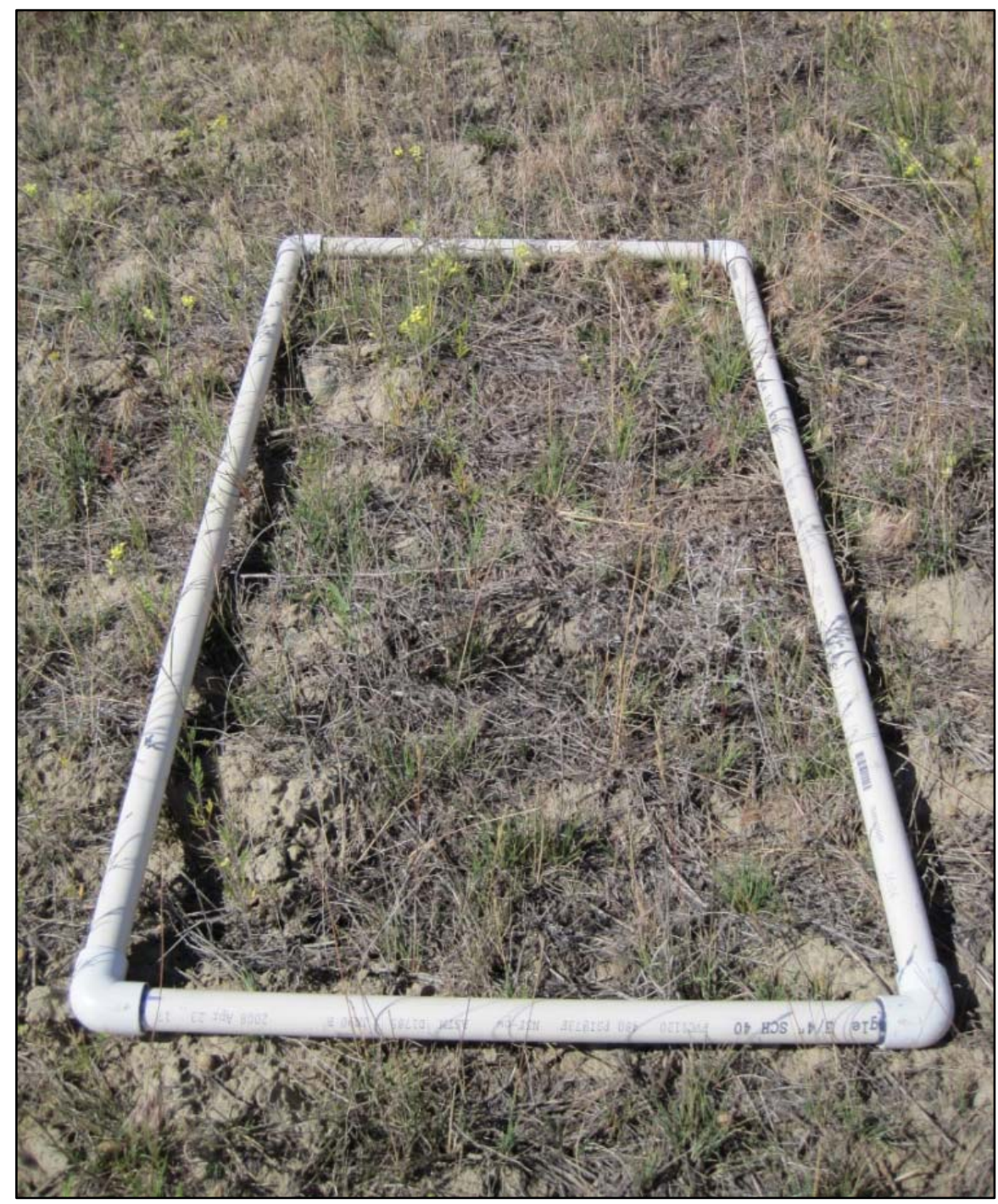

Grasses growing on the 600-149:2 site, June 2010. 
Table 25. Percent Canopy Cover and Frequency of Occurrence at 600-149:2 in 2010.

\begin{tabular}{|c|c|c|}
\hline Species & \% Cover & $\%$ Freq of Occ \\
\hline Bromus tectorum ${ }^{\text {a }}$ (cheatgrass) & 10.5 & 100.0 \\
\hline Poa scabrella (pine bluegrass) & 8.7 & 80.0 \\
\hline Poa sandbergii (Sandberg's bluegrass) & 5.7 & 100.0 \\
\hline Sisymbrium altissimum ${ }^{\mathrm{a}}$ (tumble mustard) & 4.0 & 93.3 \\
\hline Descurainia pinnata (western tansymustard) & 2.3 & 60.0 \\
\hline Draba verna ${ }^{\mathrm{a}}$ (spring whitlowgrass) & 2.0 & 80.0 \\
\hline Salsola kali (Russian thistle) & 1.8 & 73.3 \\
\hline Agropyron spicatum (bluebunch wheatgrass) & 1.5 & 60.0 \\
\hline Sitanion hystrix (bottlebrush squirreltail) & 1.5 & 60.0 \\
\hline Holosteum umbellatum ${ }^{\mathrm{a}}$ (jagged chickweed) & 1.3 & 53.3 \\
\hline Stipa comata (needle-and-thread grass) & 1.3 & 20.0 \\
\hline Achillea millefolium (yarrow) & 0.7 & 26.7 \\
\hline Artemisia tridentata (big sagebrush) & 0.3 & 13.3 \\
\hline Oryzopsis hymenoides (Indian ricegrass) & 0.2 & 6.7 \\
\hline Hordeum leporinum ${ }^{\mathrm{a}}$ (hare barley) & 0.2 & 6.7 \\
\hline Poa bulbosa $a^{\mathrm{a}}$ (bulbous bluegrass) & 0.2 & 6.7 \\
\hline Plantago patagonica (Indian wheat) & 0.2 & 6.7 \\
\hline Festuca octoflora (slender sixweeks) & 0.2 & 6.7 \\
\hline Chrysothamnus nauseosus (gray rabbitbrush) & $\mathrm{X}$ & $\mathrm{X}$ \\
\hline Grayia spinosa (spiny hopsage) & $\mathrm{X}$ & $\mathrm{X}$ \\
\hline Lactuca serriola ${ }^{\text {a }}$ (prickly lettuce) & $\mathrm{X}$ & $\mathrm{X}$ \\
\hline Eriogonum niveum (snow buckwheat) & $\mathrm{X}$ & $\mathrm{X}$ \\
\hline Ambrosia acanthicarpa (bur ragweed) & $\mathrm{X}$ & $\mathrm{X}$ \\
\hline Crust & 0.0 & 0.0 \\
\hline Soil & 49.8 & 100.0 \\
\hline Litter & 31.0 & 100.0 \\
\hline Total canopy cover (litter not included) & 42.5 & \\
\hline \multicolumn{3}{|l|}{$\begin{array}{l}{ }^{\mathrm{a}} \text { Invasive species } \\
\mathrm{X}=\text { present but not counted in plot frames }\end{array}$} \\
\hline Total Invasive \% Cover & 20.8 & \\
\hline Total Native \% Cover & 21.7 & \\
\hline Change in Native \% Cover from 2009 & -26.7 & \\
\hline
\end{tabular}




\subsection{REVEGETATION MITIGATION}

In 2003, the Environmental Restoration Disposal Facility (ERDF) began Phase III expansion to construct disposal cells 5 and 6 . Construction of the new cells occurred entirely within the disturbed footprint of the ERDF fence. However, an area south of the perimeter fence was impacted by placement of the overburden pile. The Mitigation Action Plan for ERDF was updated to develop appropriate mitigation strategies for this and future expansions (DOE-RL 2005b).

At the time of the initial construction of the ERDF in 1995, a majority of the 4.1- $\mathrm{km}^{2}\left(1.6-\mathrm{mi}^{2}\right)$ area was dominated by mature sagebrush and late successional grasses and forbs and considered high-quality, Level III habitat, as defined in BRMaP (DOE-RL 2001). Compensatory mitigation actions conducted for the construction of ERDF Cells 1 through 4 were based on a replacement ratio of 3:1 as appropriate for Level III sagebrush habitat. The large fire in the summer of 2000 burned most of the $4.1-\mathrm{km}^{2}\left(1.6-\mathrm{mi}^{2}\right)$ area identified for future ERDF expansion. Although the area has started to recover, it is no longer dominated by an overstory of sagebrush and no longer fits the definition of Level III habitat. Late successional grasses and forbs are still present; however, live mature sagebrush are sparse and the area now meets the definition of Level II habitat. However, since the understory of grasses and forbs are still intact and a small component of sagebrush still exists, some level of mitigation/rectification was needed. The Mitigation Action Plan determined that the appropriate mitigation ratio for the area south and east of ERDF would be 1:1. Construction activities at ERDF and impacts from expanding Borrow Pit 30 to supply gravel, required that approximately 20 ha (50 acres) of mitigation be performed.

To maximize the effectiveness of the mitigation effort, sagebrush was planted on 25 ha (62 acres) that included four 4-ha (10-acre) islands separated by $100 \mathrm{~m}$ (328 ft) in February 2007. Each island was planted at a density of 1,000 plants per hectare (400 plants/acre). The areas between the islands were planted at a density of 444 plants per hectare (180 plants/acre) in an area south of ERDF that straddles the Army Loop Road (Figure 25). This configuration takes advantage of the Army Loop Road, which could serve as fire break or natural location to fight a fire if one should threaten this area.

In addition to planting sagebrush, 10 artificial burrowing owl nest boxes were installed in the area (Figure 26). Burrowing owls have been observed in this area previously, and this will increase the opportunity for nesting pairs to become established in the area. 
Figure 25. ERDF Mitigation Site Along Army Loop Road.

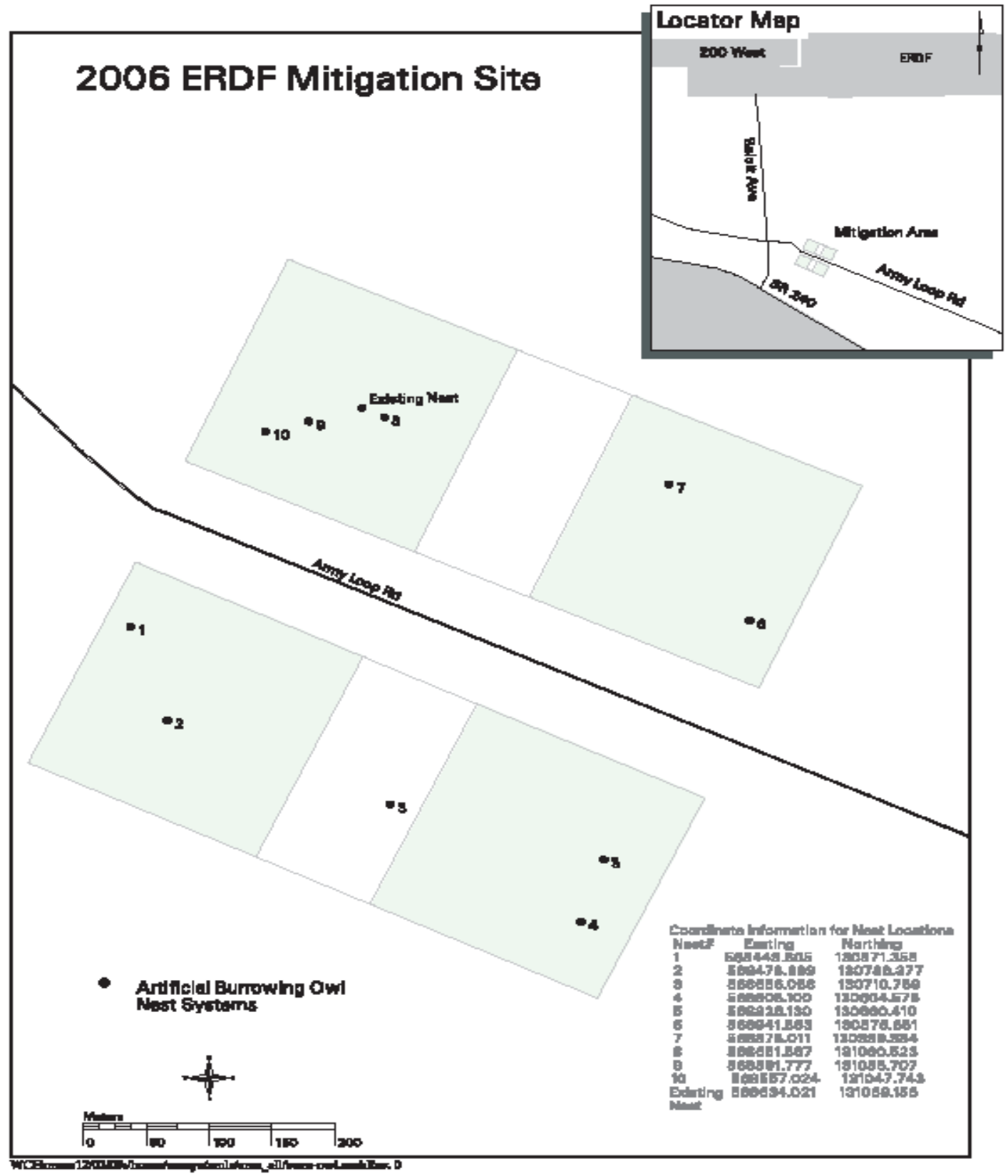


The burrowing owl nest boxes were maintained and monitored during 2010. There is some information in the available literature that shows that disturbance around the entry of an artificial burrow may attract owls. So during maintenance, which typically involves removing soil and debris from the opening of the tunnels, soil was dug out in front of the entry to imitate the soil mound at the opening of a badger burrow (Figure 26). Subsequent monitoring showed no burrowing owl activity in the area during the spring/summer of 2010.

Figure 26. Burrowing Owl Nest Box Maintenance.

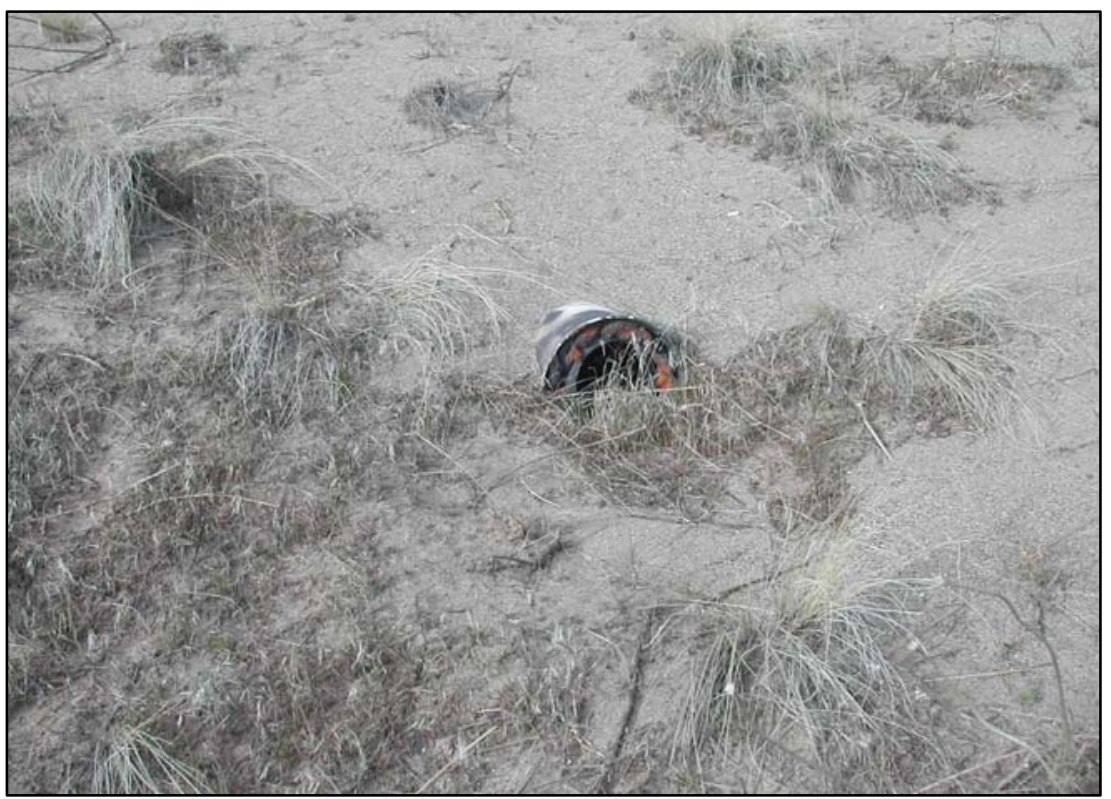

Burrowing owl nest box entrance before maintenance.

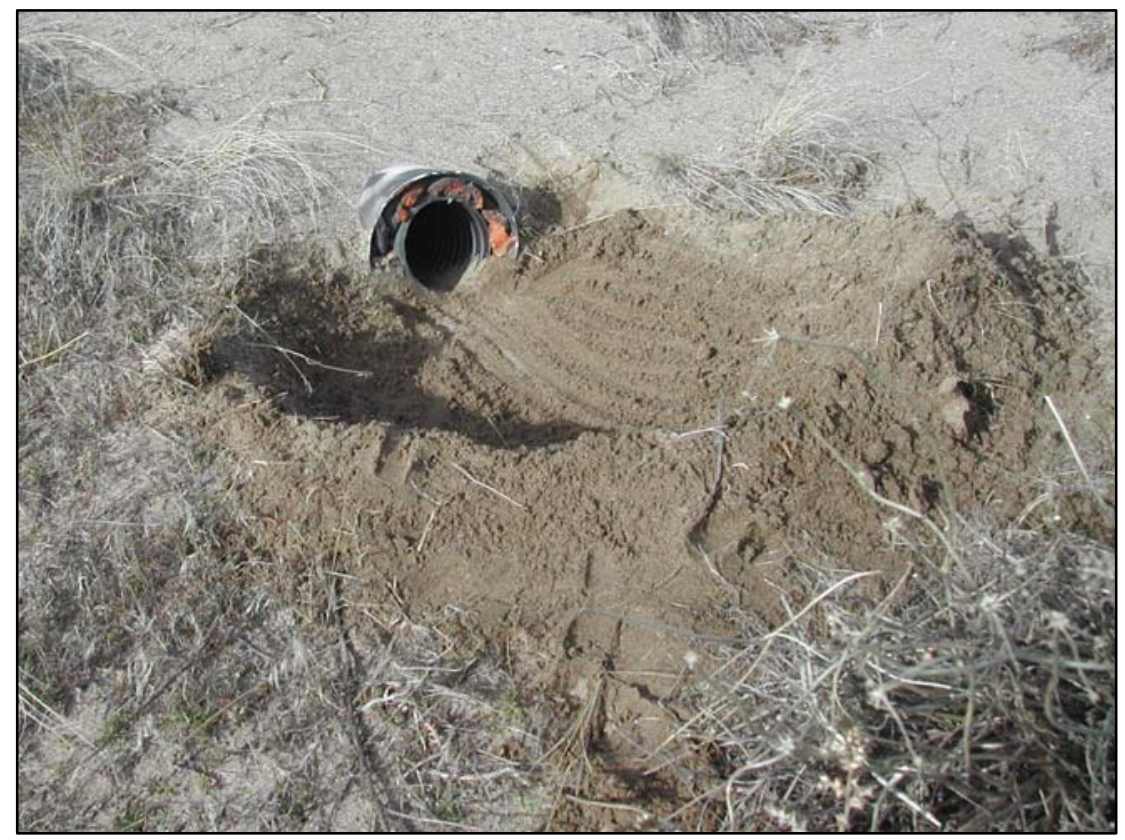

Burrowing owl nest box entrance after maintenance. 
Third-year monitoring of mitigation for disposal cells 5 and 6 that was conducted in 2009 of the sagebrush transects planted along the Army Loop Road yielded survival of 22\% and 36\%. To compensate for the low shrub survival, 7,200 sagebrush seedlings were planted in January 2010 at the same time as the mitigation for planting of 31,100 seedlings for the construction of the ERDF disposal cell 9 and expansion and use of Pit 30. The rectification planting along with the cell 9 mitigation planting were installed along the north side of the BC Cutoff road (Figure 27). First-year monitoring of the Cell 9 mitigation monitoring transects had mixed results. The sagebrush seedlings planted between November 30 and December 3, 2009 just before an extended period of freezing temperatures and frozen ground had dismal survival, less than an estimated 5\% and is considered a complete loss. Shrubs planted after January 4, 2010 were monitored by vendor with plant survival ranging from $10 \%$ to $62 \%$. To compensate for the reduced shrub survival within Cell 9 mitigation planting and construction of ERDF disposal cell 10, an additional 56,500 seedlings will be planted in the fall of FY11 north of the BC Cutoff road. The previously monitored plants plus all new installations will be monitored for survival.

Figure 27. ERDF Mitigation Planting, January 2010.

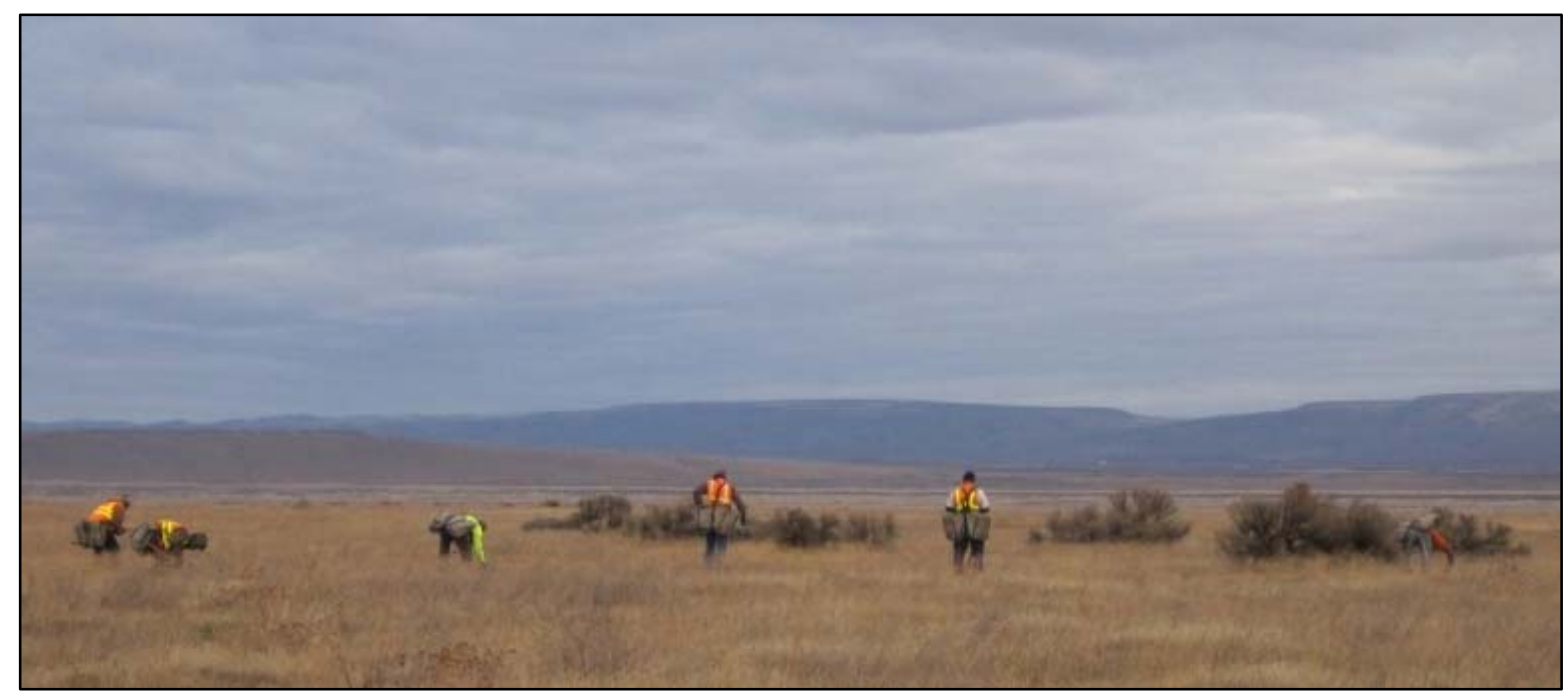

Sagebrush planting north of the BC Cutoff road, January 2010. 


\subsection{BAT MITIGATION PROJECTS}

Bat mitigation projects have been conducted at two reactor sites, 105-D/DR and 105-F, to mitigate for roosting habitat that was lost as a result of the Interim Safe Storage (ISS) projects at these reactors. The purpose of the ISS projects was to remove all of the ancillary structures from the reactor buildings, seal all penetrations, and install new steel roofs to prevent intrusion from animals. Ecological reviews conducted prior to the initiation of these projects identified the presence of multiple bat species utilizing the reactors as maternity roosts, where they rear their young. These bats are listed as Washington State priority species at communal roosts and breeding areas and require mitigation according to the BRMaP (DOE-RL 2001). The mitigation projects conducted at the reactor sites included establishing the process water tunnels at 100-D Area as alternative roost sites and installing artificial roost boxes at 105-F Reactor. A third mitigation project was initiated at the 183-F Clearwell in July 2007 to begin investigating a colony of more than 2,000 bats that are using that facility. The facility is slated for eventual demolition, so a mitigation plan was needed to determine the path forward for this facility and the bats occupying it.

\subsection{BAT MITIGATION AT 100-D AREA}

The mitigation project at 100-D Area was initiated when a suspected maternity roost was discovered in one of the process water tunnels connected to the 105-DR Reactor. The ISS project plan included isolating the tunnels from the reactor, which would eliminate the bats' access to the tunnels and cause the loss of the maternity roost. Approval and concurrence from the U.S. Department of Energy, Richland Operations Office in a letter from James D. Goodenough to S. D. Liedle, dated July 28, 1998, (DOE-RL 1998) provided direction to maintain bat access and mitigate for roosting habitat that would be lost as a result of ISS. Alternate accesses were provided on both tunnel systems that entered the 105-DR valve pit by installing bat gates on access hatches (Figure 28). One tunnel originated at the 190-D Water Pump House, as a redundant water supply, and two tunnels originated from the 190-DR Water Pump House that come together just west of the valve pit. The original purpose of these tunnels was to provide the primary cooling water supply for the 105-DR Reactor (Figure 29). The noncontaminated process water tunnels are built with a zig-zag design to allow for expansion of the piping. Each straight leg of the tunnels contains a surface hatch to provide access in case a pipe section had to be replaced. These surface hatches provide the actual roost sites for the bats because of the solar heating of the hatch covers, providing a favorable site to rear young. The bat gates were placed over hatches on both tunnel systems. The gate on the 190-D tunnel was installed in the fall of 1998 and the gate on the 190-DR tunnel system was installed in the fall of 1999. 
Figure 28. 190-DR Bat Gate.

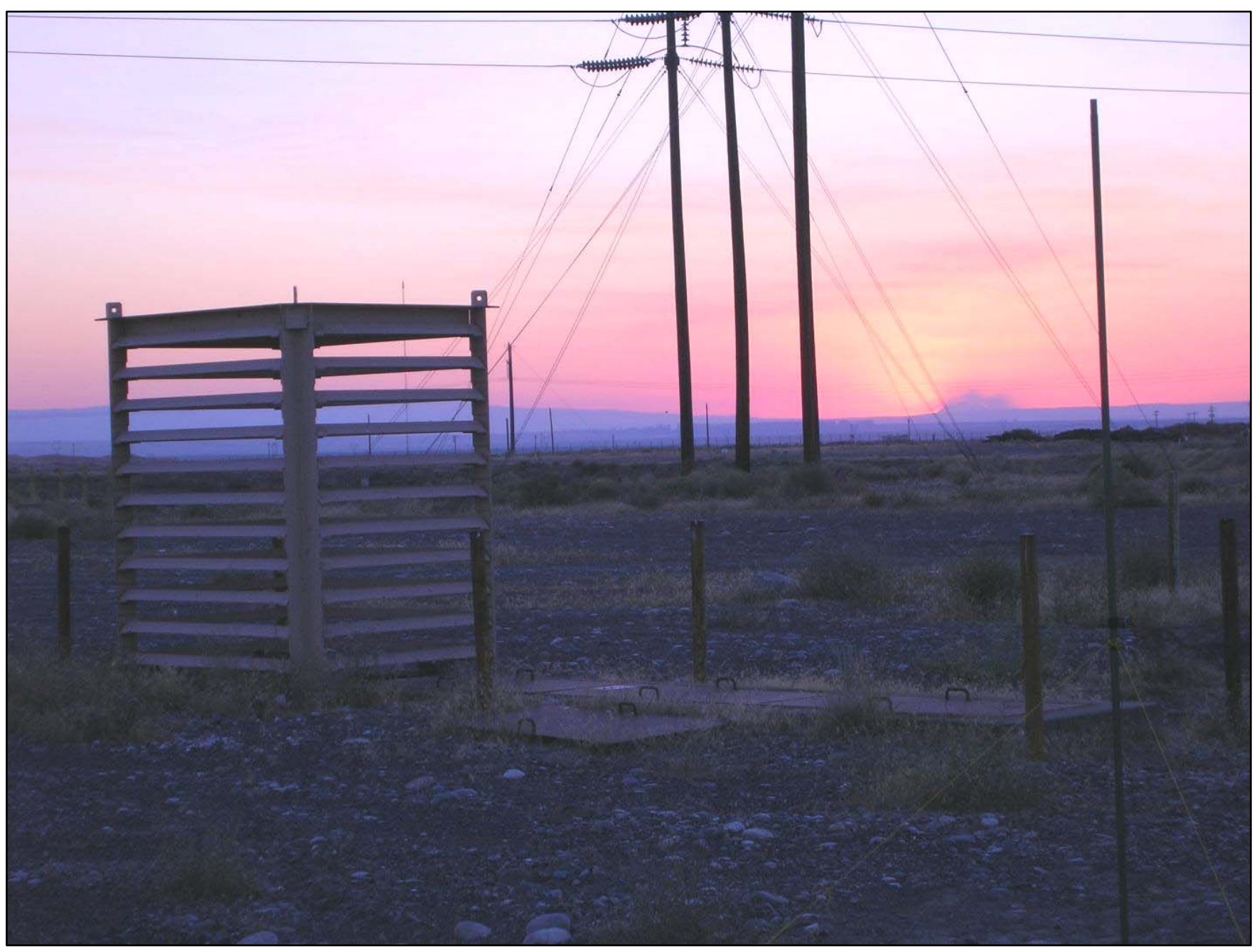


Figure 29. 190-D/DR Tunnel System.

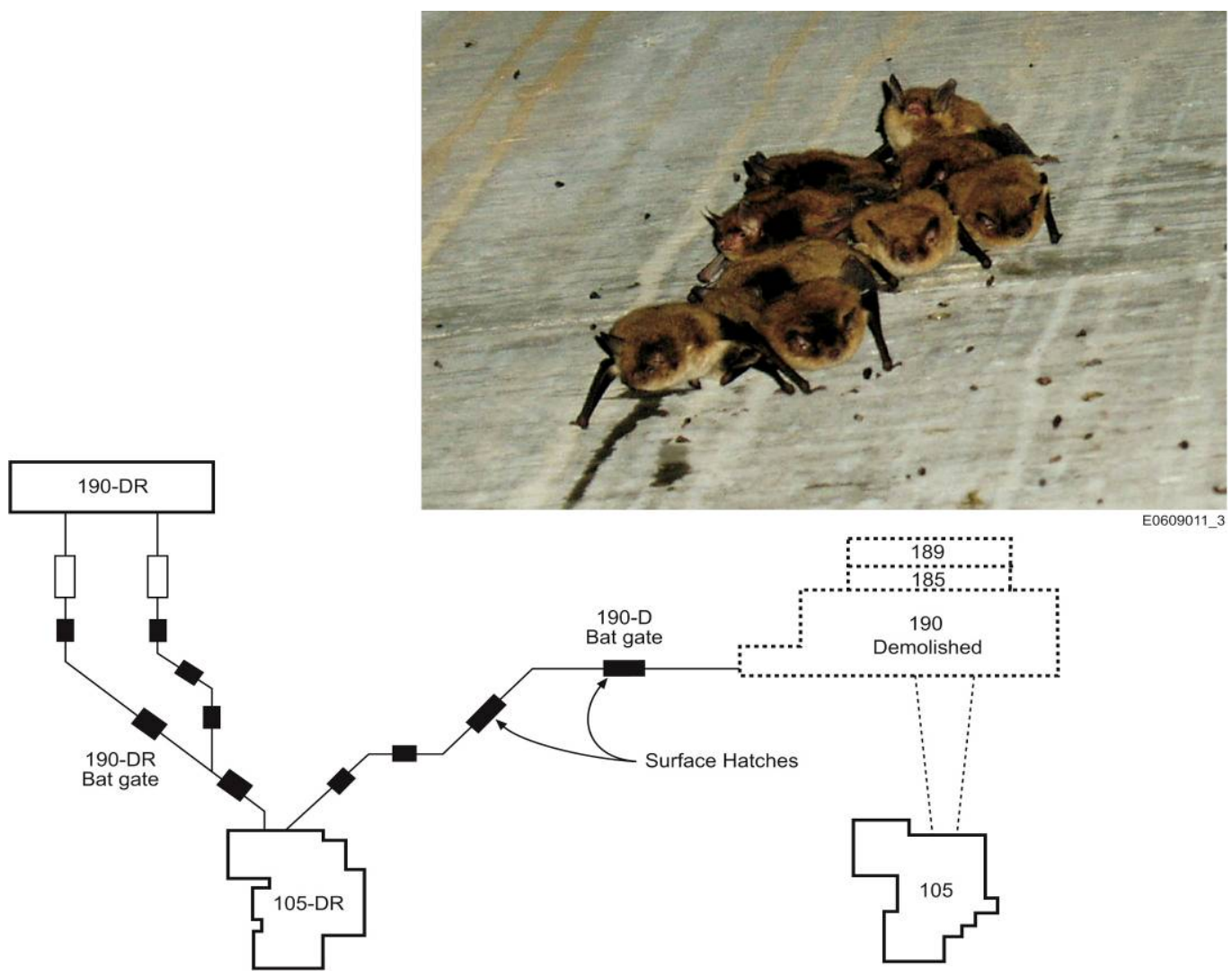

Monitoring of bat roosting began in July 1999. The gate on the 190-D tunnel had been installed and the tunnels were still accessible from the reactor valve pit. There were approximately 19 bats observed in the 190-D tunnel and 36 in the 190-DR tunnels. No inspection of the tunnels was made during the year 2000; however, a small number of bats were observed emerging from the gates in August 2000 approximately 1 hour after sundown, which verified that they had found the bat gate entrance and were continuing to use the tunnels. No observations were made during 2001.

The 190-D tunnel has not been entered since the reactor valve pit was backfilled because there is no walk-in access available. However, video recording of the emergence from the bat gate at the 190-D tunnel, using an infrared video camera, allowed for an estimation of the population using this structure. On July 7, 2010, approximately 340 individuals were observed exiting through the bat gate. This number is much higher than the 30-40 individuals that have been counted previously, using manual counting techniques. This now represents a very sizable colony, but the relationship between this colony and the colony at the 190-DR tunnels is not well understood. Counts in subsequent years will be performed on the same dates, in order to approximate total colony size. 
The 190-DR tunnels were accessible from the 190-DR north valve house (at the west end of the tunnel) until 2005 when the valve houses were demolished along with the 190-DR facility. At the completion of the demolition project, a walk-in door was provided in the south tunnel where it connected to the valve house. Inspections of the 190-DR tunnels have been conducted from 2002 to 2005, and the number of bats roosting in the hatches was counted. The numbers counted were as follows: 107 in 2002, 99 in 2003, 98 in 2004, and 97 in 2005. A second inspection was made on July 27, 2005, and a total of 170 bats were counted. The bats appeared to roost at all the hatches except the ones where the bat gates are located. Often the majority of the population would roost in the same hatch which would contain several small clusters ranging from 5 to 50 . These clusters are maternity colonies consisting of mothers with their young.

In July 2006, it was discovered that someone had placed chicken wire over the entrance to the 190-DR bat gate during the previous winter, which prevented the bats from flying through the gate and roosting in the tunnel. The chicken wire was immediately removed and the tunnel was again inspected for bats on September 21, 2006. There were about 20 bats found roosting as individuals and small clusters. Because the roost site in 190-DR was not available to the bats for most of the summer of 2006, the bat gate on190-D tunnel was monitored for emerging bats on August 9, 2006, and 25 to 35 bats were counted emerging from the tunnel. The bats would often circle the bat gate and occasionally go back in, making it difficult to get an accurate count.

In 2007, mist netting was performed at the 190-DR process water tunnel, in order to capture bats. This was done in conjunction with other bat monitoring activities going on the 183-F Clearwell. The purpose was to determine which species were present and to determine genetic relationships of the bats at the 100-D Area site to bats of the same species in the 183-F Clearwell. Morphometric measurements and DNA samples were collected to definitively determine the species and any genetic relationships between the two sites. The species present in the 190-DR tunnel are Yuma Myotis (Myotis yumanensis), as determined by morphometrics, acoustic analysis, and DNA analysis. Eighteen bats were captured on August 28, 2007, and four on September 11, 2007 (Figure 30). The population was a mix of adults and juveniles, and only three individuals were males. On September 13, 2007, a team entered the 190-DR tunnels to do a visual inspection of the bats present. Video and still photographs were taken of the bats within the roost, and 108 bats were counted on the video. Several clusters of 10 to 25 bats were observed, indicating the hatches are again being used as a maternity roost. Two data loggers were deployed during the same entrance; they will log temperature/relative humidity data at the roost sites. This data will be compared to that found in the 183-F Clearwell, to see how the temperature trends compare between the structures.

A walkdown was performed to assess the number of bats using the roost on September 22, 2008. The total number of bats observed in the 190-DR tunnel was 67.

Monitoring in 2009 included entry into the 190-DR tunnel, on September 16, 2009, to videotape bats and capture individuals. The video photography is used to count the total number of bats using the structure, and captured individuals are assessed to determine species, sex, age, and reproductive status. During the entry, two nulliparous adult females (individuals that have never give birth), two parous adult females (individuals that have given birth), and three nulliparous juveniles were captured. The presence of juveniles shows that this site remains a viable maternity roost. A total of 77 bats were observed in the 190-DR tunnel, with 63 of them 
(roosting in several clusters) observed in one of the hatches, indicating the site is still functioning as a maternity roost. This number is up slightly from the number recorded in 2008, but is not near the 170 recorded in July 2007. The differing numbers may be due to the timing of the monitoring, a shift of the maternity colony to another facility, a reduction in population, or other unknown factors.

Monitoring of the 190-DR tunnel in 2010 was delayed until September 27. A total of 32 bats were observed during the walkdown. Counting methods were to record all bats observed with an infrared video camera, and then count bats on the video after exiting the tunnel. One nulliparous female and two males were captured and hand released. Due to the late timing of this walkdown, it is not known whether a larger colony is still using the facility. Coordination of the monitoring of 190-D and 190-DR tunnels in the future, at a time when the bats are known to be using the maternity colony sites and while the young are vagrant, will allow for a combined count of the colonies at these two locations.

Figure 30. 190-DR in 2010.

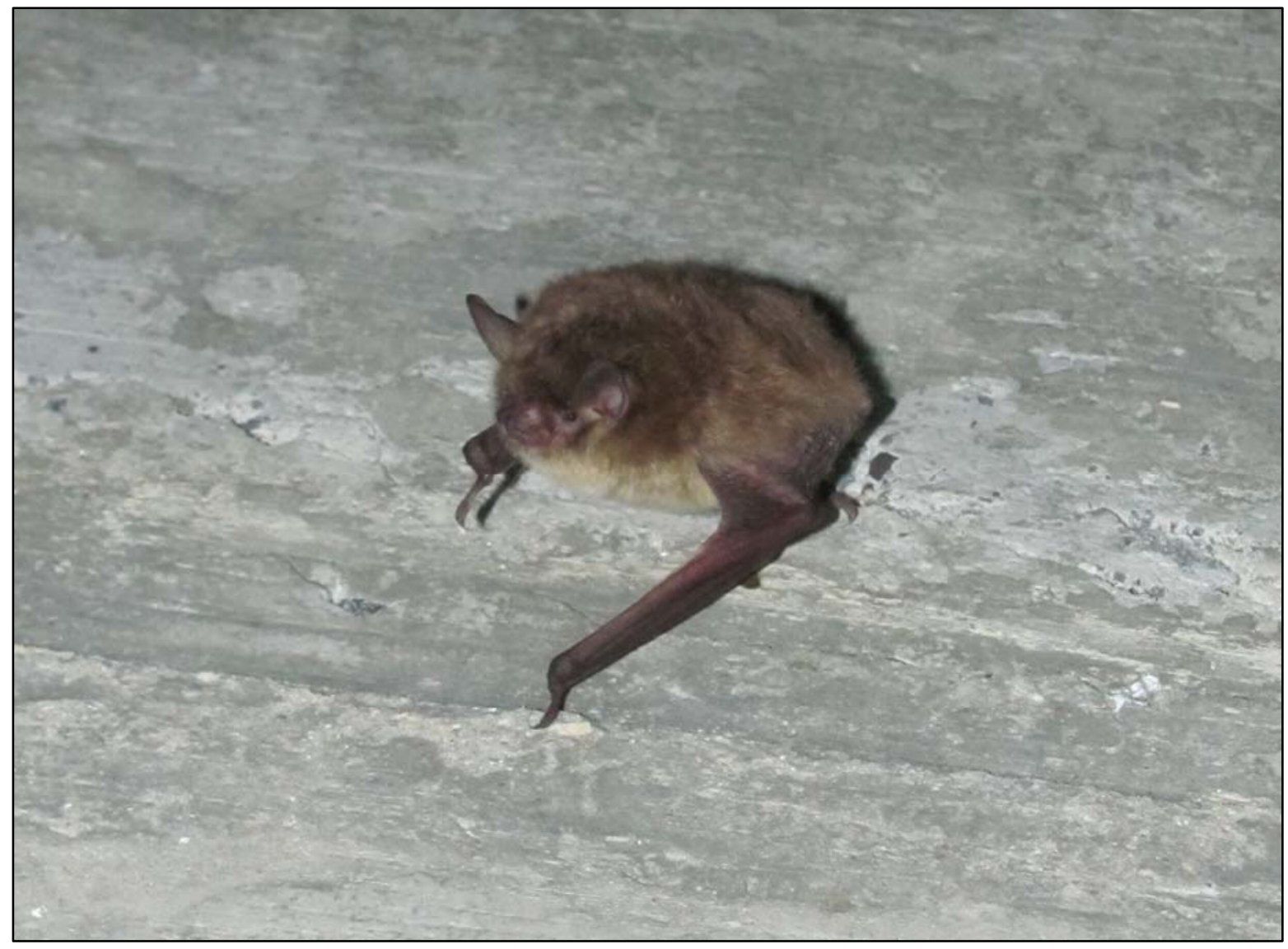

Yuma myotis observed in the 190-DR tunnel on September 27, 2010. 
The status of bats and their roost sites in the 100-D Area is becoming increasingly complex. In addition to the two known roosts sites in the two tunnel systems, bat activity has been discovered at the 183-D Water Treatment Facility. It became apparent in 2010 that a colony of pallid bats (Antrozous pallidus) is using the 183-D Headhouse. Approximately 14 individuals were observed exiting the facility through a crack in the cinderblock wall. In addition, bats were observed entering an open door on the third floor of the headhouse shortly after sunset. It is unknown at this time if an additional roost site exists within another portion of the 183-D facility. Monitoring at this site will continue at this site to determine the extent of use. Further monitoring may help to establish if existing colonies are shifting to new locations, if one colony is supplying recruits to the new roost site, or if colonies are unrelated.

\subsection{BAT MITIGATION AT 100-F REACTOR}

Bats had been observed on several occasions roosting inside the 105-F Reactor building during the initial phases of the ISS project which began in FY 2000. In the spring of 2003, a maternity colony of pallid bats (Antrozous pallidus) was observed in the upper areas of the reactor building. Other species (Myotis sp.) were also observed in the reactor. The 105-F Reactor had served as both a communal roost and a breeding area for these bat species, therefore, mitigation efforts were initiated to remove the bats from the building unharmed and provide alternate roosting habitat.

As the new roof was being completed in August 2003, steps were taken to remove the bats from the building to prevent them from being trapped inside. The main ground-floor entrance to the building was left open to serve as the only access to the building. After a week of acclimation to the new access, a piece of plywood with three 2-in. slots cut in it was placed over the door to narrow the entrance. The slots were fitted with landing boards mounted on the inside of the door to allow the bats to land and crawl out. The first night after the board was installed, the narrowed entrance was observed to ensure the bats could get out. The slotted door was left in place for 1 week and on September 8, 2003, exclusion netting was installed loosely over the slotted door and stapled to the top and sides so the bats had to crawl through the slots and out the bottom of the netting to get out. Once out, they could not get back in.

Alternative roosts were provided by installing eight commercially made bat roosts (Figure 26). Bat boxes designed to house pallid bats were installed on the east side of the building (boxes 1 and 2 ), the south side (boxes 4 and 6), the west side of the building (box 7), and one on a utility pole approximately $50 \mathrm{~m} \mathrm{NE}$ of the building (box 8). Two boxes designed for Myotis bats were installed on the south side of the building (boxes 3 and 5).

Follow-up surveys confirmed that the pallid bats were utilizing the houses mounted on the building. Because of the difficulty in counting bats inside the boxes, it is impossible to get an exact count; however, it was estimated that the colony contained approximately 30 individuals in September 2003 using box number 1 exclusively. Very few Myotis bats were observed roosting in bat boxes designed for them (boxes 3 and 5).

The following spring, the pallid bats returned from winter hibernation to use the boxes on the reactor. During 2004, they continued to primarily use box 1 on the northeast side of the building, 
but by the end of the summer, they had used all of the pallid bat boxes on the reactor building (1, 2, 4, 6, and 7) but had not used the one mounted on the utility pole (8). Myotis continued to infrequently use boxes 3 and 5 , but not as a maternity colony.

In 2006, the pallid bats began returning to the roost site at 105-F Reactor in April. Fresh pallid bat guano was observed under the boxes on April 11, 2006. During the spring months (April and May) the bats appeared to prefer the roosts on the south side of the building, probably because these sites were the warmest. As the summer progressed, they appeared to prefer boxes 1 and 2 on the east side of the building. On August 3, 2006, all boxes were inspected for the presence of bats. Boxes 1 and 2 appeared to have approximately the same number of bats present (judged by how many could be counted by looking into the entrance from below). The emergence of bats from box 2 was observed and a total of 41 bats were counted. Assuming box 1 had approximately the same number of individuals present, the population could have been as high as 80 individuals. This is a substantial increase since the mitigation project began in 2003 when the population was estimated to be approximately 30 .

Due to the excavation of waste sites around the 105-F Reactor building, no surveys or counts were conducted at the bat houses in 2007. Visual inspections, as well as acoustic surveys and the presence of bat guano confirmed that the Pallid bats did return in 2007.

On September 25, 2008, mist netting was conducted at the 105-F Reactor to determine if the roost site was still active. Pallid bats were observed in 3 of the 8 boxes (boxes 2, 7, and 8). Nine pallid bats and one Myotis yumanensis were captured in two nets. All of the pallid bats were female and some appeared to have given birth this year indicating this is still a successful maternity colony. One of the bats captured was a recapture of an individual that was banded in September 2006.

Monitoring for 2009 was performed at 105-F Reactor on August 31. Two mist nets were placed near the reactor, and two infrared video cameras were set up to record emergence at two of the seven bat boxes. Two nulliparous juvenile pallid bats were captured in the mist nets (Figure 31), showing that this site remains an active and successful maternity colony. One of the individuals was light tagged, which consists of attaching a small glo-stick to the bat to allow the bat to be identified in flight. The calls of the bat were recorded, as intended, but the bat was also observed entering the eve of the 105-F Reactor roof. This shows that bats may potentially be using the eves of the 105-F Reactor roof for roosting habitat. There is still evidence, in the form of guano, that bats are using the bat houses around the different sides of the reactor. A video camera was placed on Bat Houses \#2 and \#4 to record emergence for 1 hour. No bats were observed exiting House \#2, but between 19 and 34 pallid bats were observed using box 4. Over the hour, bats were observed entering and exiting the box, so an exact count was not possible. 


\section{Figure 31. Mitigation Monitoring at 105-F Reactor.}

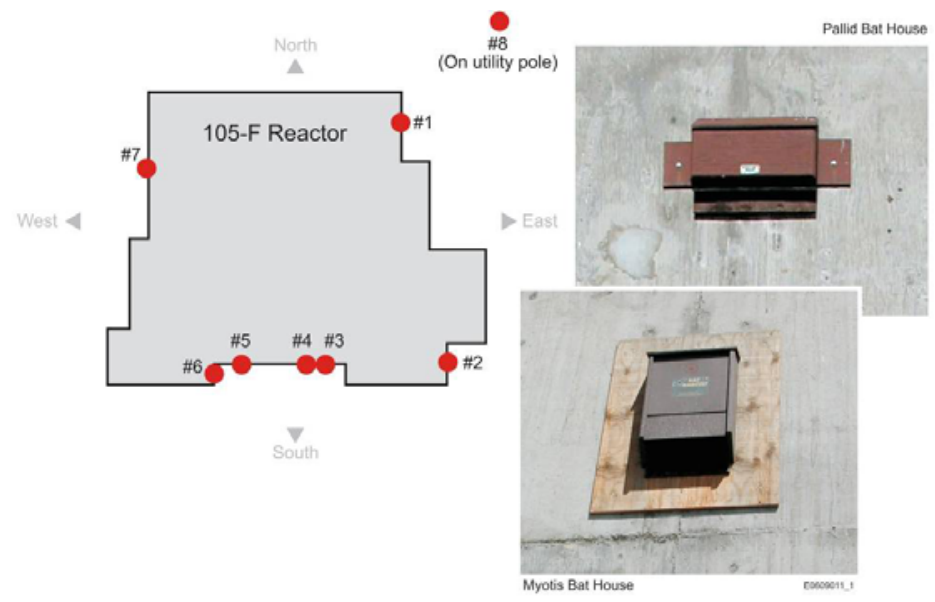

Location of bat houses placed around the 105-F Reactor.

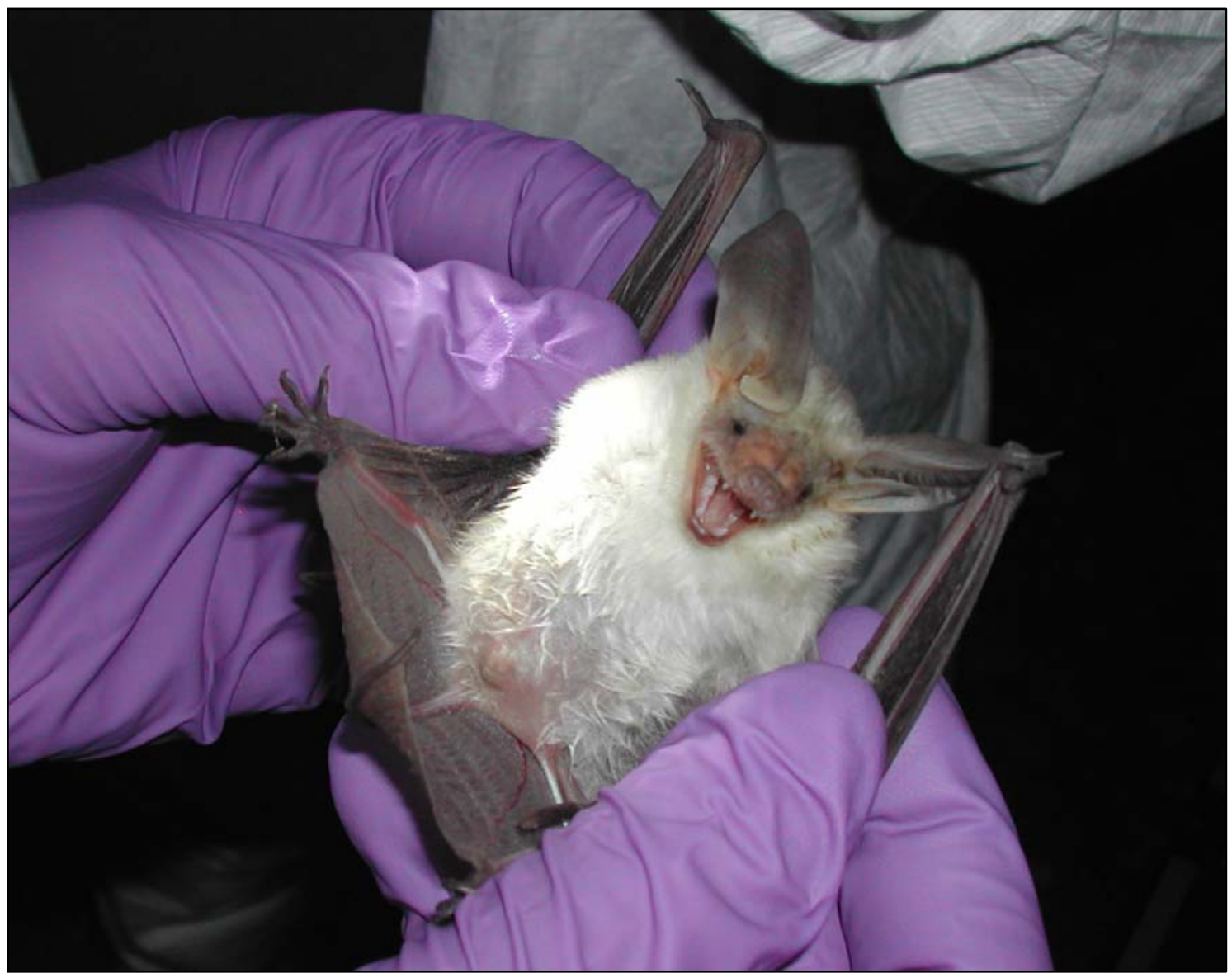

Female pallid bat captured at the 105-F Reactor during 2010 monitoring. 
During monitoring at the 105-F Reactor, acoustic detectors were being used to record bat echolocation calls. Many pallid bat calls were recorded, including several "social calls," which the bats are using for communication rather than navigation. These "social calls" are diagnostic of pallid bats and are often the only way to tell their calls from the calls of big brown bats (Eptesicus fuscus). In addition, one Yuma myotis, one small-footed myotis, and five western pipistrel (Pipistrellus hesperus) calls were recorded on August 31, 2009. This shows the high level of bat activity in the area included multiple species, which is another indication of how ideal the area is for supporting bats.

Between 53 and 76 pallid bats were recorded exiting one of the bat boxes at the 105-F on June 16, 2010. It becomes difficult to accurately count the number of individuals using a specific box, due to individuals exiting and returning to the boxes throughout the night. Due to the many roosting areas available to the pallid bats in this area, including 8 bat boxes and the whole reactor, it is not possible to accurately assess population size. On August 17, 2010, a triple-high mist net was deployed near the 105-F Reactor. Four pallid bats were captured, all were observed to be nulliparous juvenile females in good condition.

\subsection{3-F CLEARWELL MATERNITY COLONY}

A bat habitat mitigation project began at the 183-F Clearwell during the summer of 2007. Preliminary counts estimated the population at over 2,000 individuals, making this colony one of the largest in the state of Washington. Because the clearwell is a maternity roost, it is considered a priority habitat by the Washington Department of Fish and Wildlife. This colony was studied because the clearwell structure was slated to be demolished and a mitigation plan needed to be developed to prevent significant impact or loss of the maternity colony. Information needed in order to advise on mitigation actions included determining the bat species present, and the habitat conditions that make the clearwell such an attractive and successful roost site. Roost sites with this many individuals are unusual, and it was important to understand how the facility was being used to determine the potential impacts from the various endstate options.

A combination of morphological measurements, acoustic analysis of echolocation calls, and DNA analysis was performed on bats collected during 2007 and 2008, and these data were used for species determination. The initial morphological measurements and acoustic analysis indicated that the colony is composed of Yuma Myotis (Myotis yumanensis). Results from the DNA analysis of skin tissue samples confirmed the identification as Yuma Myotis.

The results of the bat study at the 183-F clearwell showed that the facility is very complex and is suitable for bat roosting in many locations during different times of the year. The building supports one of the largest maternity colonies of bats in the state, and may also support some level of winter activity. For these reasons, the project report stated that the preferred mitigation for the site would be to leave the clearwell and flume in place, and to place signs and fencing around the facility to prevent unauthorized entry (Gano et al. 2009).

In January 2009 the DOE sent a letter to WCH staff stating that they intend to maintain the 183-F clearwell and flume long term, and in order to allow the colony to thrive, they instructed 
WCH to install passive human-access restrictions to the facility including signs and fencing (Figure 31). The fencing and signage were constructed in April 2009.

Mitigation monitoring was performed at the 183-F clearwell and flume during August 2009. Two mist nets were set up near the clearwell hatch, and infrared cameras were placed at the clearwell hatch and flume entrance to count emergence. A total of eight Yuma myotis and one small-footed myotis were captured in the mist nets. There were five nulliparous female Yuma myotis and three parous female Yuma myotis; all individuals were adults. The small-footed myotis was a nonreproductive adult male (Figure 30). When released, the small-footed myotis was seen entering the clearwell through the open hatch. This was the first evidence of a second species using the clearwell. Adult males do not typically roost with a congregation of females, so this is not an indication that a second species is using the facility as a maternity roost.

In 2009, video monitoring was performed for 1 hour at the clearwell hatch and 1 hour at the flume entrance beginning at the start of the emergence. A total of 2,367 bats were counted over 62 minutes of emergence at the 183-F clearwell hatch. The emergence was observed to continue for 15 minutes following the end of the video. The polynomial average was extracted out to estimate the remainder of the emergence, and the total emergence was estimated to include 2,640 individuals. Approximately 120 bats were observed exiting the flume entrance.

No mist netting was performed at the clearwell in 2010. Emergence counts were performed at the site using an infrared video camera on June 16, 2010, and again on August 17. A total of 3,539 bats were observed emerging from the facility on June 16, and 3637 were observed emerging on August 17. These numbers represent the largest recorded to date at this facility, and confirm the clearwell as the largest known colony of bats in the state of Washington.

The 2010 monitoring information shows that the roost continues to support a large maternity colony. The importance of monitoring colonies is heightened with the emergence of white nose syndrome (WNS) in the eastern United States. It is important that baselines can be established prior to any impacts from WNS, and that any emergence of WNS can be quickly identified. The monitoring of this colony, as well as the other colonies that have been identified, will continue to be reported on in this document in coming years. This information can be used for comparison from year to year, to determine if there are any changes in the condition of the bats or the status of the colonies.

\subsection{SNAKE MITIGATION}

In November 2005, remediation of a portion of the 128-B-3 Burn Pit excavated an area containing several large boulders. The void spaces between the boulders contained an active snake hibernaculum (den) from which several rattlesnakes were brought to the surface during the excavation of the burn pit debris. 
Snake hibernacula often contain mixed species of snakes. In the Columbia Basin, species such as the western rattlesnake (Crotalus viridis), gopher snake (Pituophis catenifer), yellow-belly racer (Coluber constrictor), and potentially the striped whipsnake (Masticophis taeniatus) often den together for the winter (Larsen 1997). Though not often popular with the general public, snakes play an important role in a healthy ecosystem by keeping small mammal and insect populations in check. They also serve as a prey species for higher trophic species such as coyotes and raptors. The Hanford Site provides suitable habitat for this species and it has been recorded on site on very rare occasions. Because the striped whipsnake will den with rattlesnakes, and because denning sites are critically important to maintaining healthy snake populations, it is important to preserve these sites (Larsen 1997).

By the time the hibernaculum at the 128-B-3 site was discovered, it was too late to preserve the site; it had been destroyed during the excavation. However, as the remediation continued, a mitigation plan was developed to reconstruct the hibernaculum. The clean boulders were segregated and stockpiled until the site was cleared for backfilling in the fall of 2006. The boulders were then pushed back into the excavation, forming several void spaces that could potentially be used by snakes. In addition to re-creating habitat for snakes, the void spaces were expected to provide habitat for numerous other species including deer mice, bushy-tailed woodrats, cottontail rabbits, porcupines, and possibly even coyotes.

The site has been monitored for wildlife usage, by searching the site for tracks and scat, each spring since 2007. Evidence of Nuttall's cottontail (Sylvilagus nuttallii), North American Porcupine (Erethizon dorsatum), and Bushy-tailed Woodrat (Neotoma cinerea) usage has been observed, but no snakes have been seen. Because of the secretive nature of snakes, it is difficult to determine their presence. The most efficient method to determine whether a location is being used by snakes is to set up a specialized snake trap.

During April 2010, the site was monitored using a drift fence in association with funnel traps to determine if snakes have found the reconstructed hibernaculum. Snakes will typically enter hibernacula in late September to October time frame and leave around mid- to late April. Monitoring was performed in the spring, when snakes are typically found leaving winter hibernacula for summer foraging areas. The drift fence was be placed along one side of the boulder pit, as the purpose of this monitoring is to determine whether snakes are using the location, not to conduct a complete inventory.

Approximately $120 \mathrm{ft}$ of silt fencing was placed (staked) around the north side of the hibernaculum on 4-13-2010 (Figure 32). The bottom 2 in. of the fence was dug into the soil to prevent snakes from going under the fence. Four funnel traps (Row and Blouin-Demiers 2006) were placed down the length of the fence. Snakes leaving the hibernaculum would encounter and move along the fence, potentially going into the funnel traps. The drift fence trap was open for five trap-nights and closed/removed on April 22, 2010.

No snakes were captured during this study's trapping period. As stated previously, the purpose of this monitoring was to assess the effectiveness of this artificial snake den in replacing the previously existing snake habitat. Continued monitoring will help to determine the extent of use by snakes, if any, at this mitigation site. 
This snake monitoring information was documented by Jonathan Lucas, WCH.

Figure 32. 128-B-3.

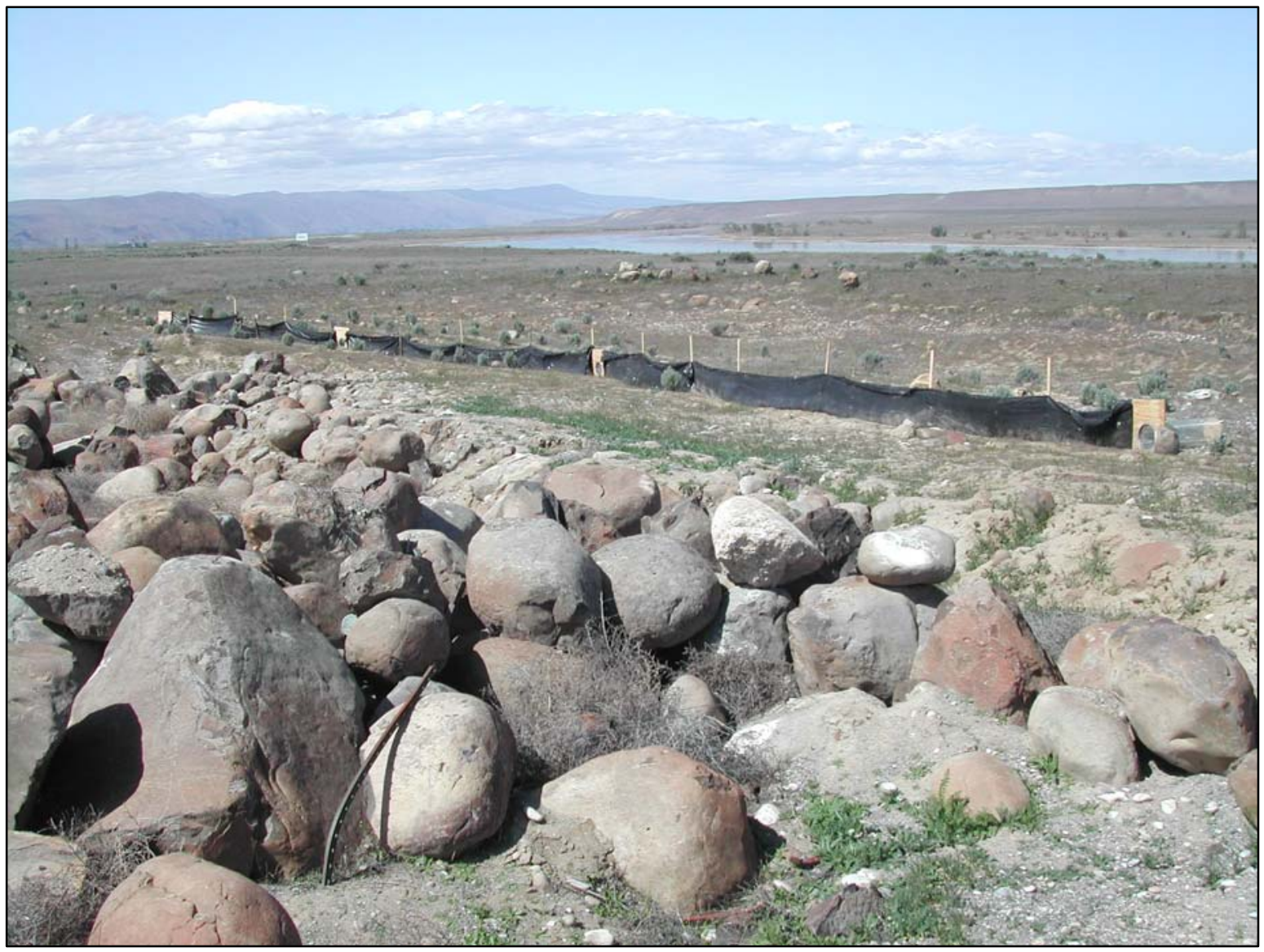

Monitoring at the 128-B-3 snake den mitigation during 2010. 


\subsection{REFERENCES}

61 FR 51019, "Notice of Deletion of the Hanford 1100 - Area (USDOE) from National Priorities List,” Federal Register, Vol. 61, No. 190, p. 51019, September 30, 1996.

Comprehensive Environmental Response, Compensation, and Liability Act of 1980, 42 U.S.C. 9601, et seq.

Daubenmire, R., 1970, Steppe Vegetation of Washington, Washington Agricultural Experiment Station Technical Bulletin 62, Washington Agricultural Experiment Station, Pullman, Washington.

DOE-RL, 1996, Superfund Site Final Closeout Report, Administrative Record Number 0044910, U.S. Department of Energy, Richland Operations Office, Richland, Washington.

DOE-RL, 1998, "Mitigation for Loss of Bat Habitat in the 105-DR Reactor Facility," CCN 060625 to S. D. Liedle, Bechtel Hanford, Inc., from J. D. Goodenough, U.S. Department of Energy, Richland Operations Office, Richland, Washington, July 27.

DOE-RL, 1999, Removal Action Workplan for the Hanford Generating Plant Ancillary Facilities, DOE/RL-99-61, Rev. 0, U.S. Department of Energy, Richland Operations Office, Richland, Washington.

DOE-RL, 2000, Remedial Design Report/Remedial Action Work Plan for the 100-NR-1 Treatment, Storage, and Disposal Units, DOE/RL-2000-16, Rev. 1, U.S. Department of Energy, Richland Operations Office, Richland, Washington

DOE-RL, 2001, Hanford Site Biological Resources Management Plan, DOE/RL-96-32, Rev. 0, U.S. Department of Energy, Richland Operations Office, Richland, Washington.

DOE-RL, 2002, Evaluation of Risk to Ecological Receptors from DDT at the Horseshoe Landfill, DOE/RL-2002-35, Rev. 0, U.S. Department of Energy, Richland Operations Office, Richland, Washington.

DOE-RL, 2005a, Remedial Design Report/Remedial Action Work Plan for the 100 Area, DOE/RL-96-17, Rev. 5, U.S. Department of Energy, Richland Operations Office, Richland, Washington.

DOE-RL, 2005b, Revised Mitigation Action Plan for the Environmental Restoration Disposal Facility, DOE/RL-2005-27, Rev. 0, U.S. Department of Energy, Richland Operations Office, Richland, Washington.

Ecology, 2000, 100-NR-1 Interim Remedial Action Record of Decision (ROD), Washington State Department of Ecology, Olympia, Washington. 
Ecology, EPA, and DOE, 1999, Action Memorandum 100 N Area Ancillary Facilities, U.S. Department of Energy Hanford Site, Richland, Washington, Washington State Department of Ecology, Olympia Washington, and U. S. Environmental Protection Agency Region 10, Seattle, Washington.

EPA, 1993, Declaration of the Record of Decision, U.S. Department of Energy, Hanford 1100 Area, U.S. Environmental Protection Agency, Region 10, Seattle, Washington.

EPA, 1999, Interim Action Record of Decision for the 100-BC-1, 100-BC-2, 100-DR-1, 100-DR-2, 100-FR-1, 100-FR-2, 100-HR-1, 100-HR-2, 100-KR-1, 100-KR-2, 100-IU-2, 100-IU-6, and 200-CW-3 Operable Units, Hanford Site, Benton County, Washington, U.S. Environmental Protection Agency, Washington State Department of Ecology, and U.S. Department of Energy, Olympia, Washington.

Gano, K. A. and C. T. Lindsey, 2007, 2007 River Corridor Closure Contractor Revegetation Monitoring Report, WCH-223, Rev. 0, Washington Closure Hanford, Richland, Washington.

Gano, K. A., J. G. Lucas, and C. T. Lindsey, 2009, Identification and Protection of a Bat Colony in the 183-F Clearwell: Mitigation of Bat Habitat on the Hanford Site, WCH-312, Rev. 0, Washington Closure Hanford, Richland, Washington.

Hitchcock, C. L., and A. Cronquist, 1973, Flora of the Pacific Northwest, University of Washington Press, Seattle, Washington.

Johnson, A. L. and K. A. Gano, 2006, 2006 River Corridor Closure Contractor Revegetation Monitoring Report, WCH-133, Rev. 0, Washington Closure Hanford, Richland, Washington.

Larsen, E. M., editor, 1997, Management Recommendations for Washington's Priority Species, Volume III: Amphibians and Reptiles, Wash. Dept. Fish and Wildl., Olympia. 122 pp.

Lindsey, C. T. and K. A. Gano, 2008, 2008 River Corridor Closure Contractor Revegetation Monitoring Report, WCH-288, Rev. 0, Washington Closure Hanford, Richland, Washington.

Lindsey, C. T., K. A. Gano, and R. D. Teel, 2009, 2009 River Corridor Closure Contractor Revegetation Monitoring Report, WCH-362, Rev. 0, Washington Closure Hanford, Richland, Washington.

McLendon, T., E. F. Redente, and C. J. Kemp, 1997, Revegetation Manual for the Environmental Restoration Contractor, BHI-00971, Rev. 0, Bechtel Hanford, Inc., Richland, Washington.

Row, J. R. and G. Blouin-Demeirs, 2006, “An Effective and Durable Funnel Trap for Sampling Terrestrial Herpetofauna,” Herpetological Review, 37(2), 183-185. 
Sackschewsky, M. R., and J. L. Downs, 2001, Vascular Plants of the Hanford Site, PNNL-13688, Pacific Northwest National Laboratory, Richland, Washington.

WAC 173-340, "Model Toxics Control Act - Cleanup," Washington Administrative Code, 1996, 2001. 


\section{APPENDIX A}

\section{REVEGETATION MONITORING RESULTS}


WCH-428

Rev. 0 
Table A-1. Percent Canopy Cover and Frequency of Occurrence at 300-8 in 2009.

\begin{tabular}{|c|c|c|}
\hline Species & \% Cover & Freq of Occ \% \\
\hline Bromus tectorum* (cheatgrass) & 48.8 & 96.0 \\
\hline Agropyron cristatum (crested wheatgrass) & 18.3 & 96.0 \\
\hline Holosteum umbellatum* (jagged chickweed) & 2.9 & 56.0 \\
\hline Poa sandbergii (Sandberg’s bluegrass) & 2.7 & 68.0 \\
\hline Salsola kali* (Russian thistle) & 2.3 & 72.0 \\
\hline Draba verna* (spring whitlow) & 1.7 & 48.0 \\
\hline Festuca octoflora (slender sixweeks) & 0.9 & 16.0 \\
\hline Machaeranthera canescens (hoary aster) & 0.7 & 8.0 \\
\hline Sisymbrium altissimum* (tumble mustard) & 0.5 & 20.0 \\
\hline Chrysothamnus nauseosus (gray rabbitbrush) & 0.3 & 12.0 \\
\hline Oryzopsis hymenoides (Indian ricegrass) & 0.1 & 4.0 \\
\hline Epilobium paniculatum (tall willowherb) & 0.1 & 4.0 \\
\hline Erodium cicutarium (storksbill) & 0.1 & 4.0 \\
\hline Artemisa tridentata (big sagebrush) & 0.1 & 4.0 \\
\hline Tragopogon dubius (yellow salsify) & $\mathrm{X}$ & $\mathrm{X}$ \\
\hline Chondrilla juncea (rush skeletonweed) & $\mathrm{X}$ & $\mathrm{X}$ \\
\hline Astragalus caricinus (buckwheat milkvetch) & $\mathrm{X}$ & $\mathrm{X}$ \\
\hline Hymenopappus filifolius (Columbia cutleaf) & $\mathrm{X}$ & $\mathrm{X}$ \\
\hline Oryzopsis hymenoides (Indian ricegrass) & $\mathrm{X}$ & $\mathrm{X}$ \\
\hline Chrysothamnus viscidiflorus (green rabbitbrush) & $\mathrm{X}$ & $\mathrm{X}$ \\
\hline Petalostemon ornatum (western prairieclover) & X & $X$ \\
\hline Poa bulbosa (bulbous bluegrass) & $\mathrm{X}$ & $\mathrm{X}$ \\
\hline Achillea millefolium (yarrow) & $\mathrm{X}$ & $\mathrm{X}$ \\
\hline Centaurea diffusa (diffuse knapweed) & $\mathrm{X}$ & $\mathrm{X}$ \\
\hline Oenothera pallida (pale eveningprimrose) & $\mathrm{X}$ & $\mathrm{X}$ \\
\hline Balsamorhiza careyana & $\mathrm{X}$ & $\mathrm{X}$ \\
\hline Agropyron spicatum (bluebunch wheatgrass) & $\mathrm{X}$ & $\mathrm{X}$ \\
\hline Biotic crust & 2.1 & 44.0 \\
\hline Bare soil & 52.1 & 96.0 \\
\hline Litter & 42.8 & 96.0 \\
\hline Total canopy cover (litter not included) & 79.5 & \\
\hline \multicolumn{3}{|l|}{ * Invasive species } \\
\hline \multicolumn{3}{|l|}{$\mathrm{X}=$ present but not counted in plot frames } \\
\hline Change in Native Cover from 2009 & -1.6 & \\
\hline Total Invasive \% Cover & 74.5 & \\
\hline Total Native \% Cover & +5.0 & \\
\hline
\end{tabular}




\section{Table A-2. Percent Canopy Cover at 618-7 Burial Ground} North, South, and CTA in 2009.

\begin{tabular}{|c|c|c|c|}
\hline Species & $\begin{array}{c}\text { \% Cover North } \\
\text { Cobble }\end{array}$ & $\begin{array}{c}\text { \% Cover South } \\
\text { Topsoil } \\
\end{array}$ & $\begin{array}{c}\text { \% Cover } \\
\text { CTA }\end{array}$ \\
\hline Salsola kali* (Russian thistle) & 8.4 & 19.3 & 10.0 \\
\hline Poa sandbergii (Sandberg's bluegrass) & 3.4 & 13.2 & 1.2 \\
\hline Agropyron spicatum (bluebunch wheatgrass) & 2.9 & 7.3 & 2.1 \\
\hline Bromus tectorum* (cheatgrass) & 0.3 & 1.4 & 0.1 \\
\hline Sisymbrium altissimum* (tumble mustard) & 0.3 & 0.3 & 0.1 \\
\hline Ambrosia acanthicarpa (bur ragweed) & $\mathrm{X}$ & 0.3 & 0.2 \\
\hline Erodium cicutarium* (storksbill) & -- & 0.2 & $\mathrm{X}$ \\
\hline Triticum aestivum (wheat) & 0.1 & -- & $\mathrm{X}$ \\
\hline Holosteum umbellatum* (jagged chickweed) & -- & 0.1 & -- \\
\hline Amsinckia lycopsoides (tarweed fiddleneck) & -- & 0.1 & $\mathrm{X}$ \\
\hline Machaeranthera canescens (hoary aster) & -- & 0.1 & -- \\
\hline Chenopodium album* (lamb's quarters) & $\mathrm{X}$ & 0.1 & $\mathrm{X}$ \\
\hline Artemisia tridentata (big sagebrush) & -- & $\mathrm{X}$ & -- \\
\hline Purshia tridentata (antelope bitterbrush) & -- & $\mathrm{X}$ & $\mathrm{X}$ \\
\hline Nama densum (purplemat) & -- & $\mathrm{X}$ & -- \\
\hline Gilia leptomeria (Great Basin gilia) & -- & $\mathrm{X}$ & -- \\
\hline Mentzelia albicaulis (whitestem stickleaf) & -- & $\mathrm{X}$ & -- \\
\hline Melilotus alba* (white sweetclover) & -- & $\mathrm{X}$ & -- \\
\hline Descurainia pinnata (western tansymustard) & -- & $\mathrm{X}$ & -- \\
\hline Vulpia myuros* (rattail fescue) & $\mathrm{X}$ & $\mathrm{X}$ & -- \\
\hline Latuca serriola* (prickly lettuce) & $\mathrm{X}$ & $\mathrm{X}$ & $\mathrm{X}$ \\
\hline Kochia scoparia (kochia) & $\mathrm{X}$ & $\mathrm{X}$ & $\mathrm{X}$ \\
\hline Chorispora tenella* (blue mustard) & $\mathrm{X}$ & $\mathrm{X}$ & -- \\
\hline Achillea millefolium (yarrow) & -- & -- & $\mathrm{X}$ \\
\hline Eriogonum niveum (snowbuckwheat) & -- & -- & $\mathrm{X}$ \\
\hline Biotic crust & 0.0 & 0.0 & 0.0 \\
\hline Bare soil & 66.5 & 66.5 & 67.7 \\
\hline Litter & 28.4 & 28.4 & 30.6 \\
\hline Total canopy cover (litter not included) & 15.4 & 42.4 & 13.7 \\
\hline \multicolumn{4}{|l|}{ * Invasive species } \\
\hline Total Invasive \% Cover & 9.1 & 21.4 & 10.2 \\
\hline Total Native \% Cover & 6.3 & 21.0 & 3.5 \\
\hline
\end{tabular}




\section{Table A-3. Percent Frequency of Occurrence at 618-7 Burial Ground North, South, and CTA in 2009.}

\begin{tabular}{|c|c|c|c|}
\hline Species & $\begin{array}{c}\text { Freq. of Occ. \% } \\
\text { North Cobble } \\
\end{array}$ & $\begin{array}{c}\text { Freq. of Occ. \% } \\
\text { South Topsoil } \\
\end{array}$ & $\begin{array}{c}\text { Freq. of Occ. \% } \\
\text { CTA } \\
\end{array}$ \\
\hline Salsola kali* (Russian thistle) & 100.0 & 100.0 & 80.0 \\
\hline Poa sandbergii (Sandberg's bluegrass) & 96.0 & 100.0 & 48.0 \\
\hline Agropyron spicatum (bluebunch wheatgrass) & 96.0 & 100.0 & 64.0 \\
\hline Bromus tectorum* (cheatgrass) & 12.0 & 36.0 & 4.0 \\
\hline Sisymbrium altissimum* (tumble mustard) & 12.0 & 12.0 & 4.0 \\
\hline Ambrosia acanthicarpa (bur ragweed) & $\mathrm{X}$ & 12.0 & 8.0 \\
\hline Erodium cicutarium* (storksbill) & -- & 8.0 & $\mathrm{X}$ \\
\hline Triticum aestivum (wheat) & 4.0 & -- & $\mathrm{X}$ \\
\hline Holosteum umbellatum* (jagged chickweed) & -- & 4.0 & -- \\
\hline Amsinckia lycopsoides (tarweed fiddleneck) & -- & 4.0 & $\mathrm{X}$ \\
\hline Machaeranthera canescens (hoary aster) & -- & 4.0 & -- \\
\hline Chenopodium album* (lamb's quarters) & $\mathrm{X}$ & 4.0 & $\mathrm{X}$ \\
\hline Artemisia tridentata (big sagebrush) & -- & $\mathrm{X}$ & -- \\
\hline Purshia tridentata (antelope bitterbrush) & -- & $\mathrm{X}$ & $\mathrm{X}$ \\
\hline Nama densum (purplemat) & -- & $\mathrm{X}$ & -- \\
\hline Gilia leptomeria (Great Basin gilia) & -- & $\mathrm{X}$ & -- \\
\hline Mentzelia albicaulis (whitestem stickleaf) & -- & $\mathrm{X}$ & -- \\
\hline Melilotus alba* (white sweetclover) & -- & $\mathrm{X}$ & -- \\
\hline Descurainia pinnata (western tansymustard) & -- & $\mathrm{X}$ & -- \\
\hline Vulpia myuros* (rattail fescue) & $\mathrm{X}$ & $\mathrm{X}$ & -- \\
\hline Latuca serriola (prickly lettuce) & $\mathrm{X}$ & $\mathrm{X}$ & $\mathrm{X}$ \\
\hline Kochia scoparia (kochia) & $\mathrm{X}$ & $\mathrm{X}$ & $\mathrm{X}$ \\
\hline Chrispora tenella* (blue mustard) & $\mathrm{X}$ & $\mathrm{X}$ & -- \\
\hline Achillea millefolium (yarrow) & -- & -- & $\mathrm{X}$ \\
\hline Erogonum niveum (snowbuckwheat) & -- & -- & $\mathrm{X}$ \\
\hline Biotic crust & 0.0 & 0.0 & 0.0 \\
\hline Bare soil & 100.0 & 100.0 & 100.0 \\
\hline Litter & 100.0 & 100.0 & 100.0 \\
\hline
\end{tabular}

* Invasive species

$\mathrm{X}=$ present but not counted in plot frames 


\section{Table A-4. Percent Canopy Cover and Frequency of Occurrence at the Hanford Generating Plant West Cobble and East Topsoil Sites in 2009.}

\begin{tabular}{|c|c|c|c|c|}
\hline Species & $\begin{array}{c}\text { \% Cover } \\
\text { E. Topsoil }\end{array}$ & $\begin{array}{c}\text { \% Cover } \\
\text { W. Cobble }\end{array}$ & $\begin{array}{c}\text { Freq of Occ \% } \\
\text { E. Topsoil } \\
\end{array}$ & $\begin{array}{c}\text { Freq of Occ \% } \\
\text { W. Cobble }\end{array}$ \\
\hline Poa sandbergii (Sandberg's bluegrass) & 51.0 & 58.9 & 100.0 & 96.0 \\
\hline Bromus tectorum* (cheatgrass) & 43.2 & 10.7 & 100.0 & 100.0 \\
\hline Holosteum umbellatum* (jagged chickweed) & 41.9 & 0.9 & 96.0 & 32.0 \\
\hline Chorispora tenella* (blue mustard) & 10.7 & -- & 80.0 & -- \\
\hline Sisymbrium altissimum* (tumble mustard) & 7.4 & 0.7 & 76.0 & 28.0 \\
\hline Draba verna* (spring whitlow) & 5.8 & 0.8 & 28.0 & 36.0 \\
\hline Salsola kali* (Russian thistle) & 3.9 & 2.7 & 96.0 & 88.0 \\
\hline Ranunculus testiculatus* (bur buttercup) & 3.6 & 0.1 & 52.0 & 4.0 \\
\hline Erodium cicutarium* (storksbill) & 3.0 & 0.9 & 28.0 & 16.0 \\
\hline Festuca octoflora (six-weeks fescue) & 1.3 & 0.9 & 12.0 & 40.0 \\
\hline Sitanion hystrix (bottlebrush squirreltail) & 1.0 & 4.5 & 12.0 & 44.0 \\
\hline Chondrilla juncea* (rush skeletonweed) & 0.9 & -- & 4.0 & -- \\
\hline Centaurea diffusa* (diffuse knapweed) & 0.8 & 0.8 & 12.0 & 56.0 \\
\hline Artemesia tridentata (sagebrush) & 0.7 & 0.8 & 8.0 & 12.0 \\
\hline Agropyron spicatum (bluebunch wheatgrass) & 0.3 & 6.4 & 12.0 & 48.0 \\
\hline Lactuca serriola* (prickly lettuce) & 0.2 & 0.4 & 12.0 & 0.8 \\
\hline Achillea millefolium (yarrow) & 0.1 & 0.8 & 4.0 & 4.0 \\
\hline Chrysothamnus nauseosus (gray rabbitbrush) & $\mathrm{X}$ & 2.9 & $\mathrm{X}$ & 44.0 \\
\hline Amsinckia lycopsoides (tarweed fiddleneck) & -- & 2.4 & -- & 8.0 \\
\hline Epilobium paniculatum (tall willowherb) & -- & 0.3 & -- & 20.0 \\
\hline Melilotus alba* (white sweetclover) & -- & $\mathrm{X}$ & -- & $\mathrm{X}$ \\
\hline Descurainia pinnata (western tansymustard) & -- & $\mathrm{X}$ & -- & $\mathrm{X}$ \\
\hline Machaeranthera canescens (hoary aster) & -- & $\mathrm{X}$ & -- & $\mathrm{X}$ \\
\hline Eriogonum niveum (snow buckwheat) & -- & $\mathrm{X}$ & -- & $\mathrm{X}$ \\
\hline Verbascum thapsus * (common mullein) & -- & $\mathrm{X}$ & -- & $\mathrm{X}$ \\
\hline Biotic Crust & 15.9 & 25.8 & 96.0 & 84.0 \\
\hline Bare Soil & 15.4 & 39.9 & 100.0 & 100.0 \\
\hline Litter & 75.0 & 38.0 & 100.0 & 100.0 \\
\hline Total canopy cover (litter not included) & 175.8 & 95.9 & & \\
\hline \multicolumn{5}{|l|}{ * Invasive species } \\
\hline \multicolumn{5}{|l|}{$\mathrm{X}=$ present but not counted in plot frames } \\
\hline \multicolumn{5}{|l|}{-- species not observed on site } \\
\hline Total Invasive \% Cover & 121.4 & 18.0 & & \\
\hline Total Native \% Cover & 54.2 & 77.9 & & \\
\hline Change in Native \% Cover from 2008 to 2009 & +5.2 & +19.7 & & \\
\hline
\end{tabular}




\section{Table A-5. Percent Canopy Cover and Frequency of Occurrence at 116-N-1 in 2009.}

\begin{tabular}{lcc}
\hline \multicolumn{1}{c}{ Species } & \% Cover & Freq of Occ \% \\
\hline Poa sandbergii (Sandberg's bluegrass) & 36.1 & 96.0 \\
Agropyron spicatum (bluebunch wheatgrass) & 9.8 & 84.0 \\
Bromus tectorum* (cheatgrass) & 9.2 & 96.0 \\
Sisymbrium altissimum* (tumble mustard) & 2.4 & 76.0 \\
Artemisia tridentata (big sagebrush) & 1.7 & 28.0 \\
Salsola kali* (Russian thistle) & 1.1 & 44.0 \\
Chrysothamnus nauseosus (gray rabbitbrush) & 0.7 & 8.0 \\
Lactuca serriola* (prickly lettuce) & 0.3 & 12.0 \\
Holosteum umbellatum* (jagged chickweed) & 0.1 & 4.0 \\
Draba verna* (spring whitlow) & 0.1 & 4.0 \\
Oryzopsis hymenoides (Indian ricegrass) & 0.1 & 4.0 \\
Epilobium paniculatum (tall willowherb) & 0.1 & 4.0 \\
Achillea millefolium (yarrow) & $\mathrm{X}$ & $\mathrm{X}$ \\
Erigeron poliospermus (cushion fleabane) & $\mathrm{X}$ & $\mathrm{X}$ \\
Tragopogon dubius* (yellow salsify) & $\mathrm{X}$ & $\mathrm{X}$ \\
Grayia spinosa (spiny hopsage) & $\mathrm{X}$ & $\mathrm{X}$ \\
Agropyron cristatum* (crested wheatgrass) & $\mathrm{X}$ & $\mathrm{X}$ \\
Centaurea diffusa* (diffuse knapweed) & $\mathrm{X}$ & $\mathrm{X}$ \\
Biotic crust & 0.0 & 0.0 \\
Bare soil & 45.2 & 96.0 \\
Litter & 60.5 & 100.0 \\
\hline
\end{tabular}

Total canopy cover (litter not included) 61.7

* Invasive species

$\mathrm{X}=$ present but not counted in plot frames

Total Invasive \% Cover $\quad 13.2$

Total Native \% Cover $\quad 48.5$

Change in Native Cover from $2008 \quad-0.6$ 
WCH-428

Rev. 0

\section{Table A-6. Percent Canopy Cover and Frequency} of Occurrence at 118-F-1 in 2009.

\begin{tabular}{lcc}
\hline \multicolumn{1}{c}{ Species } & \% Cover & Freq of Occ \% \\
\hline Salsola kali* (Russian thistle) & 26.8 & 100.0 \\
Agropyron spicatum (bluebunch wheatgrass) & 12.7 & 84.0 \\
Poa sandbergii (Sandberg's bluegrass) & 10.3 & 100.0 \\
Sisymbrium altissimum* (tumble mustard) & 0.6 & 24.0 \\
Bromus tectorum*(cheatgrass) & 0.5 & 20.0 \\
Holosteum umbellatum* (jagged chickweed) & 0.3 & 12.0 \\
Draba verna* (spring whitlow) & 0.3 & 12.0 \\
Sitanion hystrix (bottlebrush squirreltail) & 0.2 & 8.0 \\
Descurainia pinnata (western tansymustard) & 0.1 & 4.0 \\
Lactuca serriola*(prickly lettuce) & 0.1 & 4.0 \\
Poa bulbosa* (bulbous bluegrass) & 0.1 & 4.0 \\
Erodium cicutarium* (storksbill) & $\mathrm{X}$ & $\mathrm{X}$ \\
Chrysothamnus nauseosus (gray rabbitbrush) & $\mathrm{X}$ & $\mathrm{X}$ \\
Grayia spinosa (spiny hopsage) & $\mathrm{X}$ & $\mathrm{X}$ \\
Achillea millefolium (yarrow) & $\mathrm{X}$ & $\mathrm{X}$ \\
Artemisia tridentata (big sagebrush) & $\mathrm{X}$ & $\mathrm{X}$ \\
Biotic crust & 0.0 & 0.0 \\
Bare soil & 50.3 & 100.0 \\
Litter & 52.3 & 100.0 \\
\hline
\end{tabular}

Total canopy cover (litter not included)

52.0

* Invasive species

$\mathrm{X}=$ present but not counted in plot frames

Total Invasive \% Cover 28.7

Total Native \% Cover 23.3

Change in Native \% Cover from $2008+19.6$ 


\section{Table A-7. Percent Canopy Cover and Frequency} of Occurrence at 118-F-2 in 2009.

\begin{tabular}{lcc}
\hline \multicolumn{1}{c}{ Species } & \% Cover & Freq of Occ \% \\
\hline Salsola kali* (Russian thistle) & 28.1 & 96.0 \\
Poa sandbergii (Sandberg's bluegrass) & 22.8 & 100.0 \\
Agropyron spicatum (bluebunch wheatgrass) & 6.7 & 92.0 \\
Sisymbrium altissimum* (tumble mustard) & 5.6 & 52.0 \\
Bromus tectorum* (cheatgrass) & 4.8 & 40.0 \\
Sitanion hystrix (bottlebrush squirreltail) & 2.4 & 20.0 \\
Holosteum umbellatum* (jagged chickweed) & 0.4 & 16.0 \\
Draba verna*(spring whitlow) & 0.4 & 16.0 \\
Lactuca serriola* (prickly lettuce) & 0.2 & 8.0 \\
Phacelia linearis (threadleaf scorpionweed) & 0.1 & 4.0 \\
Oryzopsis hymenoides (Indian ricegrass) & 0.1 & 4.0 \\
Descurainia pinnata (western tansymustard) & 0.1 & 4.0 \\
Poa bulbosa (bulbous bluegrass) & $\mathrm{X}$ & $\mathrm{X}$ \\
Machaeranthera canescens (hoary aster) & $\mathrm{X}$ & $\mathrm{X}$ \\
Lepidium perfoliatum (clasping pepperweed) & $\mathrm{X}$ & $\mathrm{X}$ \\
Grayia spinosa (spiny hopsage) & $\mathrm{X}$ & $\mathrm{X}$ \\
Cardaria draba* (whitetop) & $\mathrm{X}$ & $\mathrm{X}$ \\
Phacelia linearis (threadleaf scorpionweed) & $\mathrm{X}$ & $\mathrm{X}$ \\
Amsinckia lycopsoides (tarweed fiddleneck) & $\mathrm{X}$ & $\mathrm{X}$ \\
Biotic crust & 0.0 & 0.0 \\
Bare soil & 49.3 & 92.0 \\
Litter & 42.1 & 100.0 \\
\hline Total camopy cover (litter not ing & 71.7 &
\end{tabular}

Total canopy cover (litter not included)

71.7

* Invasive species

$\mathrm{X}=$ present but not counted in plot frames

Total Invasive \% Cover 39.5

Total Native \% Cover 32.2

Change in Native cover from $2008+13.0$ 
Table A-8. Percent Canopy Cover and Frequency of Occurrence at 182-F North and South in 2009.

\begin{tabular}{|c|c|c|c|c|}
\hline Species & $\begin{array}{l}\text { \% Cover } \\
\text { North }\end{array}$ & $\begin{array}{l}\text { \% Cover } \\
\text { South }\end{array}$ & $\begin{array}{l}\text { Freq of Occ } \\
\text { \% North }\end{array}$ & $\begin{array}{c}\text { Freq of Occ } \\
\% \text { South }\end{array}$ \\
\hline Bromus tectorum* (cheatgrass) & 44.5 & 49.3 & 100.0 & 88.0 \\
\hline Agropyron spicatum (bluebunch wheatgrass) & 32.5 & 5.6 & 100.0 & 72.0 \\
\hline Poa sandbergii (Sandberg's bluegrass) & 24.0 & 19.8 & 73.3 & 92.0 \\
\hline Poa bulbosa* (bulbous bluegrass) & 10.3 & 5.9 & 60.0 & 24.0 \\
\hline Salsola kali* (Russian thistle) & 2.2 & 6.2 & 86.7 & 92.0 \\
\hline Sporobolus cryptandrus (sanddrop seed) & 1.0 & 4.1 & 6.7 & 32.0 \\
\hline Erodium cicutarium* (storksbill) & 0.3 & 1.2 & 13.3 & 28.0 \\
\hline Sisymbrium altissimum* (tumble mustard) & 0.7 & 0.8 & 26.7 & 32.0 \\
\hline Festuca octoflora (slender sixweeks) & 0.7 & 0.3 & 26.7 & 12.0 \\
\hline Draba verna* (spring whitlow) & 0.5 & 0.5 & 20.0 & 20.0 \\
\hline Artemesia tridentata (sagebrush) & 0.5 & $\mathrm{X}$ & 20.0 & $\mathrm{X}$ \\
\hline Holosteum umbellatum* (jagged chickweed) & -- & 0.4 & -- & 16.0 \\
\hline Oryzopsis hymenoides (Indian ricegrass) & 0.3 & -- & 13.3 & -- \\
\hline Centaurea diffusa* (diffuse knapweed) & $\mathrm{X}$ & 0.3 & $\mathrm{X}$ & 12.0 \\
\hline Artemesia campestris (pacific sage) & 0.2 & $\mathrm{X}$ & 6.7 & $\mathrm{X}$ \\
\hline Descurainia pinnata (western tansymustard) & -- & 0.1 & -- & 4.0 \\
\hline Verbena bracteata* (big-bract verbena) & -- & $\mathrm{X}$ & -- & $\mathrm{X}$ \\
\hline Lactuca serriola* (prickly lettuce) & -- & $\mathrm{X}$ & -- & $\mathrm{X}$ \\
\hline Achillea millefolium (yarrow) & $\mathrm{X}$ & $\mathrm{X}$ & $\mathrm{X}$ & $\mathrm{X}$ \\
\hline Astragalus succumbens (crouching milkvetch) & $\mathrm{X}$ & $\mathrm{X}$ & $\mathrm{X}$ & $\mathrm{X}$ \\
\hline Vicia cracca* (bird vetch) & $\mathrm{X}$ & $\mathrm{X}$ & $\mathrm{X}$ & $\mathrm{X}$ \\
\hline Sphaeralcea munroana (Munro's globemallow) & $\mathrm{X}$ & $\mathrm{X}$ & $\mathrm{X}$ & $\mathrm{X}$ \\
\hline Machaeranthera canescens (hoary aster) & $\mathrm{X}$ & -- & $\mathrm{X}$ & -- \\
\hline Chrysothamnus nauseosus(gray rabbitbrush) & $\mathrm{X}$ & -- & $\mathrm{X}$ & -- \\
\hline Biotic crust & 1.0 & 0.3 & 40.0 & 12.0 \\
\hline Bare soil & 41.8 & 17.7 & 93.3 & 96.0 \\
\hline Litter & 57.8 & 77.0 & 100.0 & 100.0 \\
\hline Total canopy cover (litter not included) & 117.7 & 94.5 & & \\
\hline \multicolumn{5}{|l|}{ * Invasive species } \\
\hline \multicolumn{5}{|l|}{$\mathrm{X}=$ present but not counted in plot frames } \\
\hline \multicolumn{5}{|l|}{-- species not recorded } \\
\hline Total Invasive \% Cover & 58.5 & 64.6 & & \\
\hline Total Native \% Cover & 59.2 & 29.9 & & \\
\hline Change in Native \% Cover from 2008 & +11.9 & -6.1 & & \\
\hline
\end{tabular}




\section{Table A-9. Percent Canopy Cover and Frequency} of Occurrence at 183-F East in 2009.

\begin{tabular}{|c|c|c|}
\hline Species & \% Cover & Freq of Occ \% \\
\hline Poa sandbergii (Sandberg's bluegrass) & 34.8 & 93.3 \\
\hline Salsola kali* (Russian thistle) & 17.8 & 100.0 \\
\hline Agropyron spicatum (bluebunch wheatgrass) & 16.8 & 93.3 \\
\hline Bromus tectorum* (cheatgrass) & 10.3 & 60.0 \\
\hline Ranunculus testiculatus* (bur buttercup) & 1.7 & 33.3 \\
\hline Festuca octoflora (slender sixweeks) & 1.3 & 20.0 \\
\hline Artemisia tridentata (big sagebrush) & 1.2 & 13.3 \\
\hline Sisymbrium altissimum* (tumble mustard) & 1.0 & 40.0 \\
\hline Erodium cicutarium* (storksbill) & 0.5 & 20.0 \\
\hline Chrysothamnus nauseosus (gray rabbitbrush) & 0.5 & 20.0 \\
\hline Draba verna* (spring whitlow) & 0.3 & 13.3 \\
\hline Poa bulbosa* (bulbous bluegrass) & 0.3 & 13.3 \\
\hline Holosteum umbellatum* (jagged chickweed) & 0.2 & 6.7 \\
\hline Achillea millefolium (yarrow) & 0.2 & 6.7 \\
\hline Machaeranthera canescens (hoary aster) & 0.2 & 6.7 \\
\hline Chorispora tenella* (blue mustard) & 0.2 & 6.7 \\
\hline Chrysothamnus nauseosus (gray rabbitbrush) & $\mathrm{X}$ & $\mathrm{X}$ \\
\hline Amsinckia lycopsoides (tarweed fiddleneck) & $\mathrm{X}$ & $\mathrm{X}$ \\
\hline Melilotus alba* (white sweetclover) & $\mathrm{X}$ & $\mathrm{X}$ \\
\hline Astragalus sclerocarpus (stalked-pod milkvetch) & $\mathrm{X}$ & $\mathrm{X}$ \\
\hline Plantago patagonica (Indian wheat) & $\mathrm{X}$ & $\mathrm{X}$ \\
\hline Ambrosia acanthicarpa (bur ragweed) & $\mathrm{X}$ & $\mathrm{X}$ \\
\hline Grayia spinosa (spiny hospage) & $\mathrm{X}$ & $\mathrm{X}$ \\
\hline Lactuca serriola* (prickly lettuce) & $\mathrm{X}$ & $\mathrm{X}$ \\
\hline Lepidium perfoliatum (clasping pepperweed) & $\mathrm{X}$ & $\mathrm{X}$ \\
\hline Sphaeralcea munroana (Munro's globemallow) & $\mathrm{X}$ & $\mathrm{X}$ \\
\hline Biotic crust & 0.0 & 0.0 \\
\hline Bare soil & 48.5 & 100.0 \\
\hline Litter & 46.7 & 100.0 \\
\hline Total canopy cover (litter not included) & 87.3 & \\
\hline \multicolumn{3}{|l|}{ * Invasive species } \\
\hline \multicolumn{3}{|l|}{$\mathrm{X}=$ present but not counted in plot frames } \\
\hline Total Invasive \% Cover & 32.3 & \\
\hline Total Native \% Cover & 55.0 & \\
\hline Change in Native \% Cover from 2008 & +1.5 & \\
\hline
\end{tabular}


Table A-10. Percent Canopy Cover and Frequency of Occurrence at 100-F-26 in 2009.

\begin{tabular}{|c|c|c|}
\hline Species & \% Cover & Freq of Occ \% \\
\hline Poa sandbergii (Sandberg's bluegrass) & 39.5 & 93.3 \\
\hline Bromus tectorum* (cheatgrass) & 35.5 & 93.3 \\
\hline Salsola kali* (Russian thistle) & 34.7 & 86.7 \\
\hline Agropyron spicatum (bluebunch wheatgrass) & 11.0 & 93.3 \\
\hline Sisymbrium altissimum* (tumble mustard) & 8.5 & 53.3 \\
\hline Sitanion hystrix (bottlebrush squirreltail) & 3.0 & 53.3 \\
\hline Poa bulbosa* (bulbous bluegrass) & 2.5 & 6.7 \\
\hline Oryzopsis hymenoides (Indian ricegrass) & 0.3 & 13.3 \\
\hline Holosteum umbellatum* (jagged chickweed) & 0.2 & 6.7 \\
\hline Draba verna* (spring whitlow) & 0.2 & 6.7 \\
\hline Chrysothamnus nauseosus (gray rabbitbrush) & 0.2 & 6.7 \\
\hline Artemisia tridentata (big sagebrush) & 0.2 & 6.7 \\
\hline Ranunculus testiculatus* (bur buttercup) & 0.2 & 6.7 \\
\hline Descurainia pinnata (western tansymustard) & 0.2 & 6.7 \\
\hline Lactuca serriola* (prickly lettuce) & 0.2 & 6.7 \\
\hline Machaeranthera canescens (hoary aster) & $\mathrm{X}$ & $\mathrm{X}$ \\
\hline Chenopodium album (lamb's quarters) & $\mathrm{X}$ & $\mathrm{X}$ \\
\hline Erodium cicutarium* (storksbill) & $\mathrm{X}$ & $\mathrm{X}$ \\
\hline Melilotus alba (white sweetclover) & $\mathrm{X}$ & $\mathrm{X}$ \\
\hline Grayia spinosa (spiny hopsage) & $\mathrm{X}$ & $\mathrm{X}$ \\
\hline Biotic crust & 3.0 & 20.0 \\
\hline Bare soil & 37.8 & 86.7 \\
\hline Litter & 62.5 & 100.0 \\
\hline Total canopy cover (litter not included) & 136.2 & \\
\hline \multicolumn{3}{|l|}{ * Invasive species } \\
\hline \multicolumn{3}{|l|}{$\mathrm{X}=$ present but not counted in plot frames } \\
\hline Total Invasive \% Cover & 81.9 & \\
\hline Total Native \% Cover & 54.3 & \\
\hline Change in Native \% Cover from 2008 & +31.2 & \\
\hline
\end{tabular}




\section{Table A-11. Percent Canopy Cover and Frequency of Occurrence at 118-F-5 Soil Staging Area and Burial Ground in 2009.}

\begin{tabular}{|c|c|c|c|c|}
\hline Species & $\begin{array}{c}\text { \% Cover } \\
\text { SSA } \\
\end{array}$ & $\begin{array}{c}\text { \% Cover } \\
\text { BG } \\
\end{array}$ & $\begin{array}{c}\text { Freq of Occ } \\
\% \text { SSA }\end{array}$ & $\begin{array}{c}\text { Freq of Occ } \\
\% \text { BG } \\
\end{array}$ \\
\hline Bromus tectorum* (cheatgrass) & 75.0 & 46.3 & 100.0 & 93.3 \\
\hline Salsola kali* (Russian thistle) & 28.5 & 21.8 & 93.3 & 100.0 \\
\hline Draba verna* (spring whitlow) & 7.8 & -- & 26.7 & -- \\
\hline Holosteum umbellatum* (jagged chickweed) & 2.7 & -- & 13.3 & -- \\
\hline Agropyron spicatum (bluebunch wheatgrass) & 1.8 & 2.5 & 40.0 & 100.0 \\
\hline Poa sandbergii (Sandberg's bluegrass) & 0.3 & 1.5 & 13.3 & 26.7 \\
\hline Sisymbrium altissimum* (tumble mustard) & 1.3 & 0.2 & 53.3 & 6.7 \\
\hline Microsteris gracilis (pink microsteris) & 1.3 & -- & 20.0 & -- \\
\hline Poa bulbosa* (bulbous bluegrass) & 0.7 & 0.5 & 26.7 & 20.0 \\
\hline Oryzopsis hymenoides (Indian ricegrass) & -- & 0.5 & -- & 20.0 \\
\hline Plantago patagonica (Indian wheat) & 0.5 & -- & 20.0 & -- \\
\hline Chrysothamnus nauseosus (gray rabbitbrush) & $\mathrm{X}$ & 0.3 & $\mathrm{X}$ & 13.3 \\
\hline Artemisia tridentata (big sagebrush) & 0.2 & 0.3 & 6.7 & 13.3 \\
\hline Achillea millefolium (common yarrow) & 0.3 & $\mathrm{X}$ & 13.3 & $\mathrm{X}$ \\
\hline Ambrosia acanthicarpa (bur ragweed) & 0.3 & -- & 13.3 & -- \\
\hline Amsinckia lycopsoides (tarweed fiddleneck) & 0.3 & -- & 13.3 & -- \\
\hline Epilobium paniculatum (tall willowherb) & -- & 0.2 & -- & 6.7 \\
\hline Machaeranthera canescens (hoary aster) & -- & $\mathrm{X}$ & -- & $\mathrm{X}$ \\
\hline Hordeum leporinum* (hare barley) & -- & $\mathrm{X}$ & -- & $\mathrm{X}$ \\
\hline Grayia spinosa (spiny hopsage) & $\mathrm{X}$ & -- & $\mathrm{X}$ & -- \\
\hline Biotic crust & 2.3 & 2.2 & 93.3 & 86.7 \\
\hline Bare soil & 27.7 & 55.3 & 93.3 & 100.0 \\
\hline Litter & 61.0 & 39.7 & 100.0 & 100.0 \\
\hline Total Canopy Cover (litter not included) & 121.2 & 74.2 & & \\
\hline \multicolumn{5}{|c|}{$\begin{array}{l}\text { * Introduced species. } \\
\mathrm{X}=\text { Species present but not counted in a plot frame } \\
\text {-- species not observed on site }\end{array}$} \\
\hline Total Introduced \% Cover & 116.0 & 68.8 & & \\
\hline Total Native \% Cover & 5.2 & 5.3 & & \\
\hline Change in Native \% Cover from 2008 & -13.3 & +0.3 & & \\
\hline
\end{tabular}


WCH-428

Rev. 0

\section{Table A-12. Percent Canopy Cover and Frequency of Occurrence at 118-F-6 in 2009.}

\begin{tabular}{lcc}
\hline \multicolumn{1}{c}{ Species } & \% Cover & Freq of Occ \% \\
\hline Salsola kali* (Russian thistle) & 30.9 & 92.0 \\
Agropyron spicatum (bluebunch wheatgrass) & 10.4 & 72.0 \\
Poa sandbergii (Sandberg's bluegrass) & 8.7 & 92.0 \\
Bromus tectorum* (cheatgrass) & 1.6 & 44.0 \\
Sisymbrium altissimum* (tumble mustard) & 1.5 & 40.0 \\
Artemisia tridentata (big sagebrush) & 0.1 & 4.0 \\
Lactuca serriola*(prickly lettuce) & 0.1 & 4.0 \\
Poa bulbosa* (bulbous bluegrass) & 0.1 & 4.0 \\
Sitanion hystrix (bottlebrush squirreltail) & 0.1 & 4.0 \\
Cardaria draba* (whitetop) & $\mathrm{X}$ & $\mathrm{X}$ \\
Grayia spinosa (spiny hopsage) & $\mathrm{X}$ & $\mathrm{X}$ \\
Purshia tridentata (antelope bitterbrush) & $\mathrm{X}$ & $\mathrm{X}$ \\
Biotic crust & 0.0 & 0.0 \\
Bare soil & 65.6 & 100.0 \\
Litter & 31.3 & 96.0 \\
\hline
\end{tabular}

Total canopy cover (litter not included) 53.5

* Invasive species

$\mathrm{X}=$ present but not counted in plot frames

Total Invasive \% Cover 


\section{Table A-13. Percent Canopy Cover and Frequency of Occurrence at 120-F-1 in 2009.}

\begin{tabular}{lcc}
\hline \multicolumn{1}{c}{ Species } & \% Cover & Freq of Occ \% \\
\hline Salsola kali* (Russian thistle) & 40.5 & 100.0 \\
Bromus tectorum* (cheatgrass) & 11.8 & 86.7 \\
Poa sandbergii (Sandberg's bluegrass) & 9.7 & 93.3 \\
Holosteum umbellatum* (jagged chickweed) & 6.3 & 66.7 \\
Agropyron spicatum (bluebunch wheatgrass) & 4.0 & 93.3 \\
Sisymbrium altissimum*(tumble mustard) & 2.5 & 66.7 \\
Draba verna* (spring whitlow) & 1.5 & 60.0 \\
Amsinckia lycopsoides (tarweed fiddleneck) & 1.2 & 13.3 \\
Chenopodium leptophyllum*(slimleaf goosefoot) & 0.7 & 26.7 \\
Artemisia tridentata (big sagebrush) & 0.5 & 20.0 \\
Ambrosia acanthicarpa (bur ragweed) & 0.3 & 13.3 \\
Plantago patagonica (Indian wheat) & 0.3 & 13.3 \\
Achillea millefolium (yarrow) & 0.2 & 6.7 \\
Sphaeralcea munroana (Munro's globemallow) & 0.2 & 6.7 \\
Oryzopsis hymenoides (Indian ricegrass) & 0.2 & 6.7 \\
Polemonium micranthum (annual Jacob's ladder) & $\mathrm{X}$ & $\mathrm{X}$ \\
Balsamorhiza careyana (Carey's balsamroot) & $\mathrm{X}$ & $\mathrm{X}$ \\
Astragalus sclerocarpus (stalked-pod milkvetch) & $\mathrm{X}$ & $\mathrm{X}$ \\
Chrysothamnus viscidiflorus (green rabbitbrush) & $\mathrm{X}$ & $\mathrm{X}$ \\
Phlox longifolia (longleaf phlox) & $\mathrm{X}$ & $\mathrm{X}$ \\
Astragalus caricinus (buckwheat milkvetch) & $\mathrm{X}$ & $\mathrm{X}$ \\
Microsteris gracilis (pink microsteris) & $\mathrm{X}$ & $\mathrm{X}$ \\
Stipa comata (needle-and-thread grass) & $\mathrm{X}$ & $\mathrm{X}$ \\
Phacelia linearis (threadleaf scorpionweed) & $\mathrm{X}$ & $\mathrm{X}$ \\
Oenothera pallida (pale eveningprimrose) & $\mathrm{X}$ & $\mathrm{X}$ \\
Biotic crust & 0.0 & 0.0 \\
Bare soil & 64.2 & 100.0 \\
Litter & 35.8 & \\
& &
\end{tabular}

\section{Total canopy cover (litter not included)}

* Invasive species

$\mathrm{X}=$ present but not counted in plot frames

Total Invasive \% Cover

Total Native \% Cover 


\section{Table A-14. Percent Canopy Cover and Frequency of Occurrence at 1607-F1 in 2009.}

\begin{tabular}{lcc}
\hline \multicolumn{1}{c}{ Species } & \% Cover & Freq of Occ \% \\
\hline Salsola kali* (Russian thistle) & 60.2 & 100.0 \\
Poa sandbergii (Sandberg's bluegrass) & 13.8 & 100.0 \\
Sisymbrium altissimum* (tumble mustard) & 5.7 & 93.3 \\
Bromus tectorum* (cheatgrass) & 4.3 & 73.3 \\
Agropyron spicatum (bluebunch wheatgrass) & 2.0 & 80.0 \\
Erodium cicutarium*(storksbill) & 0.5 & 20.0 \\
Draba verna*(spring whitlow) & 0.3 & 13.3 \\
Sitanion hystrix (bottlebrush squirreltail) & 0.3 & 13.3 \\
Festuca octoflora (slender sixweeks) & 0.3 & 13.3 \\
Conyza canadensis* (horseweed) & $\mathrm{X}$ & $\mathrm{X}$ \\
Sporobolus cryptandrus (sand dropseed) & $\mathrm{X}$ & $\mathrm{X}$ \\
Holosteum umbellatum* (jagged chickweed) & $\mathrm{X}$ & $\mathrm{X}$ \\
Lactuca serriola* (prickly lettuce) & $\mathrm{X}$ & $\mathrm{X}$ \\
Artemisia tridentata (big sagebrush) & $\mathrm{X}$ & $\mathrm{X}$ \\
Grayia spinosa (spiny hospage) & $\mathrm{X}$ & $\mathrm{X}$ \\
Sphaeralcea munroana (Munrow's globemallow) & $\mathrm{X}$ & $\mathrm{X}$ \\
Verbena bracteata* (big-bract verbena) & $\mathrm{X}$ & $\mathrm{X}$ \\
Tragopogon dubius*(yellow salsify) & $\mathrm{X}$ & $\mathrm{X}$ \\
Poa scabrella (pine bluegrass) & $\mathrm{X}$ & $\mathrm{X}$ \\
Biotic crust & 0.0 & 0.0 \\
Bare soil & 62.2 & 100.0 \\
Litter & 42.3 & 100.0 \\
\hline Total canopy cover (litter not includ & 87.5 & \\
\hline
\end{tabular}

Total canopy cover (litter not included)

87.5

* Invasive species

$\mathrm{X}=$ present but not counted in plot frames

Total Invasive \% Cover 


\section{Table A-15. Percent Canopy Cover and Frequency of Occurrence at 100-B-1 and 128-C-1 in 2009.}

\begin{tabular}{|c|c|c|c|c|}
\hline Species & $\begin{array}{c}\text { \% Cover } \\
100-B-1 \\
\end{array}$ & $\begin{array}{c}\text { \% Cover } \\
128-C-1 \\
\end{array}$ & $\begin{array}{c}\text { 100-B-1 Freq } \\
\text { of Occ \% }\end{array}$ & $\begin{array}{c}\text { 128-C-1 Freq of } \\
\text { Occ \% }\end{array}$ \\
\hline Poa sandbergii (Sandberg's bluegrass) & 46.1 & 34.2 & 100.0 & 100.0 \\
\hline Bromus tectorum* (cheatgrass) & 22.9 & 33.3 & 100.0 & 93.3 \\
\hline Salsola kali* (Russian thistle) & 4.1 & 7.2 & 88.0 & 86.7 \\
\hline Sisymbrium altissimum* (tumble mustard) & 3.6 & 1.5 & 48.0 & 60.0 \\
\hline Agropyron spicatum (bluebunch wheatgrass) & 3.5 & 0.3 & 24.0 & 40.0 \\
\hline Draba verna* (spring whitlow) & -- & 3.5 & -- & 13.3 \\
\hline Artemisia tridentata (big sagebrush) & 3.5 & 1.3 & 8.0 & 20.0 \\
\hline Erodium cicutarium* (storksbill) & 0.0 & $\mathrm{X}$ & 4.0 & $\mathrm{X}$ \\
\hline Amsinckia lycopsoides (tarweed fiddleneck) & 0.2 & -- & 8.0 & -- \\
\hline Sitanion hystrix (bottlebrush squirreltail) & 0.1 & 3.3 & 4.0 & 33.3 \\
\hline Microsteris gracilis (pink microsteris) & 0.3 & -- & 12.0 & -- \\
\hline Oryzopsis hymenoides (Indian ricegrass) & -- & 0.3 & -- & 13.3 \\
\hline Machaeranthera canescens (hoary aster) & -- & 0.2 & -- & 6.7 \\
\hline Lactuca serriola* (prickly lettuce) & 0.1 & $\mathrm{X}$ & 4.0 & $\mathrm{X}$ \\
\hline Grayia spinosa (spiny hopsage) & 0.1 & -- & 4.0 & -- \\
\hline Tragopogon dubius (yellow salsify) & $\mathrm{X}$ & $\mathrm{X}$ & $\mathrm{X}$ & $\mathrm{X}$ \\
\hline Balsamorhiza careyana (Carey's balsamroot) & $\mathrm{X}$ & -- & $\mathrm{X}$ & -- \\
\hline Lomatium macrocarpum (bigseed desertparsley) & $\mathrm{X}$ & -- & $\mathrm{X}$ & -- \\
\hline Poa scabrella (pine bluegrass) & $\mathrm{X}$ & -- & $\mathrm{X}$ & -- \\
\hline Sphaeralcea munroana (Munro's globemallow) & $\mathrm{X}$ & $\mathrm{X}$ & $\mathrm{X}$ & $\mathrm{X}$ \\
\hline Astragalus succumbens (crouching milkvetch) & $\mathrm{X}$ & -- & $\mathrm{X}$ & -- \\
\hline Chrysothamnus nauseosus (gray rabbitbrush) & -- & $\mathrm{X}$ & -- & $\mathrm{X}$ \\
\hline Verbena bracteata* (big-bract verbena) & -- & $\mathrm{X}$ & -- & $\mathrm{X}$ \\
\hline Chondrilla juncea* (rush skeletonweed) & -- & $\mathrm{X}$ & -- & $\mathrm{X}$ \\
\hline Biotic crust & 15.8 & 0.0 & 100.0 & 0.0 \\
\hline Bare soil & 46.3 & 27.7 & 100.0 & 100.0 \\
\hline Litter & 43.4 & 61.0 & 100.0 & 100.0 \\
\hline Total canopy cover (litter not included) & 84.5 & 85.2 & & \\
\hline \multicolumn{5}{|l|}{ * Invasive species } \\
\hline \multicolumn{5}{|l|}{$\mathrm{X}=$ present but not counted in plot frames } \\
\hline \multicolumn{5}{|l|}{-- species not present on site } \\
\hline Total Invasive \% Cover & 30.7 & 45.5 & & \\
\hline Total Native \% Cover & 53.8 & 39.7 & & \\
\hline Total Change in Native Cover from 2007 & +6.5 & 0.0 & & \\
\hline
\end{tabular}




\section{Table A-16. Percent Canopy Cover and Frequency of Occurrence at 100-C-9 in 2009.}

\begin{tabular}{|c|c|c|c|c|c|c|}
\hline Species & $\begin{array}{l}\text { T1 \% } \\
\text { Cover }\end{array}$ & $\begin{array}{l}\text { T2 \% } \\
\text { Cover }\end{array}$ & $\begin{array}{l}\text { T3 \% } \\
\text { Cover }\end{array}$ & $\begin{array}{l}\text { T1 Freq } \\
\text { of Occ. }\end{array}$ & $\begin{array}{l}\text { T2 Freq } \\
\text { of Occ. }\end{array}$ & $\begin{array}{l}\text { T3 Freq } \\
\text { of Occ. }\end{array}$ \\
\hline Bromus tectorum* (cheatgrass) & 11.7 & 43.2 & 39.7 & 86.7 & 100.0 & 100.0 \\
\hline Poa sandbergii (Sandberg's bluegrass) & 30.3 & 10.0 & 15.0 & 93.3 & 100.0 & 93.3 \\
\hline Agropyron spicatum (bluebunch wheatgrass) & 5.2 & 0.8 & 1.5 & 80.0 & 33.3 & 60.0 \\
\hline Sisymbrium altissimum* (tumble mustard) & 0.3 & 1.2 & 4.7 & 13.3 & 46.7 & 86.7 \\
\hline Salsola kali* (Russian thistle) & 2.0 & 3.3 & 3.0 & 80.0 & 100.0 & 86.7 \\
\hline Holosteum umbellatum* (jagged chickweed) & 0.5 & 3.2 & 1.7 & 20.0 & 33.3 & 33.3 \\
\hline Artemisia tridentata (big sagebrush) & 2.5 & 0.2 & 2.0 & 33.3 & 6.7 & 13.3 \\
\hline Oryzopsis hymenoides (Indian ricegrass) & 1.3 & 0.5 & 0.5 & 53.3 & 20.0 & 20.0 \\
\hline Sitanion hystrix (bottlebrush squirreltail) & -- & 0.7 & 1.3 & -- & 26.7 & 20.0 \\
\hline Centaurea diffusa* (tumble knapweed) & -- & 0.2 & 1.3 & -- & 6.7 & 20.0 \\
\hline Draba verna* (spring whitlow) $^{*}$ & 0.3 & 0.7 & 0.8 & 13.3 & 26.7 & 33.3 \\
\hline Amsinckia lycopsoides (tarweed fiddleneck) & -- & 0.5 & -- & -- & 20.0 & -- \\
\hline Erodium cicutarium* (storksbill) & -- & 0.3 & 0.5 & -- & 13.3 & 20.0 \\
\hline Lactuca serriola* (prickly lettuce) & -- & -- & 0.5 & -- & -- & 20.0 \\
\hline Descurainia pinnata (western tansymustard) & 0.2 & -- & 0.3 & 6.7 & -- & 13.3 \\
\hline Eriogonum vimineum (broom buckwheat) & -- & 0.3 & -- & -- & 13.3 & -- \\
\hline Chrysothamnus nauseosus (gray rabbitbrush) & 0.2 & 0.2 & -- & 6.7 & 6.7 & -- \\
\hline Sporobolus cryptandrus (sand dropseed) & -- & 0.2 & -- & -- & 6.7 & -- \\
\hline Poa bulbosa* (bulbous bluegrass) & -- & 0.2 & -- & -- & 6.7 & -- \\
\hline Epilobium paniculatum (tall willowherb) & -- & 0.2 & -- & -- & 6.7 & -- \\
\hline Biotic crust & 0.0 & 0.0 & 0.0 & 0.0 & 0.0 & 0.0 \\
\hline Bare soil & 62.7 & 57.0 & 55.5 & 100.0 & 100.0 & 100.0 \\
\hline Litter & 34.7 & 36.7 & 39.8 & 93.3 & 100.0 & 100.0 \\
\hline Total canopy cover (litter not included) & 54.5 & 65.7 & 72.8 & & & \\
\hline \multicolumn{7}{|l|}{$\mathrm{X}=$ present but not counted in plot frames } \\
\hline Total Invasive \% Cover & 14.8 & 52.2 & 52.2 & & & \\
\hline Total Native \% Cover & 39.7 & 13.5 & 20.7 & & & \\
\hline Change in Native \% Cover from 2008 & +15.9 & +4.7 & -6.5 & & & \\
\hline
\end{tabular}




\section{Table A-17. Percent Canopy Cover and Frequency of Occurrence} at 118-B-2 and 118-B-3 in 2009.

\begin{tabular}{lcc}
\hline \multicolumn{1}{c}{ Species } & \% Cover & Freq of Occ \% \\
\hline Bromus tectorum* (cheatgrass) & 43.2 & 100.0 \\
Poa sandbergii (Sandberg's bluegrass) & 10.0 & 100.0 \\
Salsola kali* (Russian thistle) & 3.3 & 100.0 \\
Holosteum umbellatum* (jagged chickweed) & 3.2 & 33.3 \\
Sisymbrium altissimum*(tumble mustard) & 1.2 & 46.7 \\
Agropyron spicatum (bluebunch wheatgrass) & 0.8 & 33.3 \\
Draba verna* (spring whitlow) & 0.7 & 26.7 \\
Achillea millefolium (yarrow) & 0.5 & 20.0 \\
Lactuca serriola* (prickly lettuce) & 0.5 & 20.0 \\
Erodium cicutarium* (storksbill) & 0.3 & 13.3 \\
Chrysothamnus nauseosus (gray rabbitbrush) & 0.2 & 6.7 \\
Centaurea diffusa* (tumble knapweed) & 0.2 & 6.7 \\
Amsinckia lycopsoides (tarweed fiddleneck) & 0.2 & 6.7 \\
Artemisia tridentata (big sagebrush) & 0.2 & 6.7 \\
Oryzopsis hymenoides (Indian ricegrass) & 0.2 & 6.7 \\
Sitanion hystrix (bottlebrush squirreltail) & 0.2 & 6.7 \\
Chaenactis douglasii (hoary falseyarrow) & $\mathrm{X}$ & $\mathrm{X}$ \\
Biotic crust & 0.5 & 20.0 \\
Bare soil & 57.7 & 100.0 \\
Litter & 56.2 & 100.0 \\
\hline
\end{tabular}

Total canopy cover (litter not included)

64.5

* Invasive species

$\mathrm{X}=$ present but not counted in plot frames

bIncludes Sandberg's bluegrass, bluebunch wheatgrass, thickspike wheatgrass, Indian ricegrass, needle-and-thread grass, and prairie junegrass seedlings.

Total Invasive \% Cover 


\section{Table A-18. Percent Canopy Cover and Frequency} of Occurrence at 100-B-14 in 2009.

\begin{tabular}{lcc}
\hline \multicolumn{1}{c}{ Species } & \% Cover & Freq of Occ \% \\
\hline Salsola kali* (Russian thistle) & 15.8 & 100.0 \\
Agropyron spicatum (bluebunch wheatgrass) & 10.6 & 96.0 \\
Sisymbrium altissimum* (tumble mustard) & 4.3 & 76.0 \\
Poa sandbergii (Sandberg's bluegrass) & 2.4 & 96.0 \\
Bromus tectorum* (cheatgrass) & 2.3 & 72.0 \\
Oryzopsis hymenoides (Indian ricegrass) & 1.6 & 64.0 \\
Holosteum umbellatum* (jagged chickweed) & 1.5 & 40.0 \\
Draba verna* (spring whitlow) & 0.7 & 28.0 \\
Lactuca serriola* (prickly lettuce) & 0.3 & 12.0 \\
Chorispora tenella (blue mustard) & 0.2 & 8.0 \\
Chrysothamnus nauseosus (gray rabbitbrush) & 0.1 & 4.0 \\
Centaurea diffusa* (tumble knapweed) & 0.1 & 4.0 \\
Artemisia tridentata (big sagebrush) & 0.1 & 4.0 \\
Epilobium paniculatum (tall willowherb) & 0.1 & 4.0 \\
Tragopogon dubius* (yellow salsify) & 0.1 & 4.0 \\
Festuca octoflora (slender sixweeks) & 0.1 & 4.0 \\
Sitanion hystrix (bottlebrush squirreltail) & 0.1 & 4.0 \\
Biotic crust & 0.0 & 0.0 \\
Bare soil & 59.8 & 96.0 \\
Litter & 36.5 & 96.0 \\
\hline Total canopy cover (litter not included) & 40.4 & \\
* Invasive species & & \\
X=present but not counted in plot frames & & \\
Total Invasive \% Cover & & \\
Total Native \% Cover & & \\
Change in Native \% Cover from 2008 & 15.3 & \\
& +7.5 & \\
\end{tabular}




\section{Table A-19. Percent Canopy Cover and Frequency of Occurrence at the 118-B-1 Burial Ground and Soil Staging Area 2009.}

\begin{tabular}{|c|c|c|c|c|}
\hline Species & $\begin{array}{c}\text { \% Cover } \\
\text { BG }\end{array}$ & $\begin{array}{l}\text { \% Cover } \\
\text { SSA }\end{array}$ & $\begin{array}{c}\text { Freq of Occ \% } \\
\text { BG }\end{array}$ & $\begin{array}{c}\text { Freq of Occ \% } \\
\text { SSA }\end{array}$ \\
\hline Salsola kali* (Russian thistle) & 33.3 & 31.1 & 96.0 & 96.0 \\
\hline Poa sandbergii (Sandberg's bluegrass) & 10.6 & 6.4 & 96.0 & 96.0 \\
\hline Agropyron spicatum (bluebunch wheatgrass) & 7.4 & 8.6 & 68.0 & 76.0 \\
\hline Bromus tectorum* (cheatgrass) & 6.3 & 7.3 & 60.0 & 60.0 \\
\hline Festuca octoflora (slender sixweeks) & 1.7 & 0.3 & 12.0 & 12.0 \\
\hline Sisymbrium altissimum* (tumble mustard) & 1.0 & 2.4 & 40.0 & 56.0 \\
\hline Chrysothamnus nauseosus (gray rabbitbrush) & 0.8 & 0.1 & 12.0 & 4.0 \\
\hline Draba verna* (spring whitlow) & 0.7 & 0.1 & 8.0 & 4.0 \\
\hline Vulpia myuros* (rattail fescue) & 0.1 & 0.7 & 4.0 & 8.0 \\
\hline Melilotus alba* (white sweetclover) & $\mathrm{X}$ & 0.6 & $\mathrm{X}$ & 4.0 \\
\hline Poa bulbosa* (bulbous bluegrass) & 0.3 & -- & 12.0 & -- \\
\hline Lactuca serriola* (prickly lettuce) & 0.3 & 0.2 & 12.0 & 8.0 \\
\hline Holosteum umbellatum* (jagged chickweed) & 0.1 & 0.3 & 4.0 & 12.0 \\
\hline Erodium cicutarium* (storksbill) & -- & 0.2 & -- & 8.0 \\
\hline Koeleria cristata (prairie junegrass) & 0.1 & 0.1 & 4.0 & 4.0 \\
\hline Artemisia tridentata (big sagebrush) & $\mathrm{X}$ & 0.1 & $\mathrm{X}$ & 4.0 \\
\hline Epilobium paniculatum (tall willowherb) & 0.1 & -- & 4.0 & -- \\
\hline Centaurea diffusa* (tumble knapweed) & -- & 0.1 & -- & 4.0 \\
\hline Eriogonum niveum (snow buckwheat) & -- & 0.1 & -- & 4.0 \\
\hline Lepidium perfoliatum (clasping pepperweed) & -- & 0.1 & -- & 4.0 \\
\hline Agoseris heterophylla (annual mountain dandelion) & -- & 0.1 & -- & 4.0 \\
\hline Oryzopsis hymenoides (Indian ricegrass) & $\mathrm{X}$ & -- & $\mathrm{X}$ & -- \\
\hline Machaeranthera canescens (hoary aster) & $\mathrm{X}$ & -- & $\mathrm{X}$ & -- \\
\hline Achillea millefolium (yarrow) & $\mathrm{X}$ & $\mathrm{X}$ & $\mathrm{X}$ & $\mathrm{X}$ \\
\hline Amsinckia lycopsoides (tarweed fiddleneck) & $\mathrm{X}$ & -- & $\mathrm{X}$ & -- \\
\hline Erodium cicutarium* (storksbill) & $\mathrm{X}$ & -- & $\mathrm{X}$ & -- \\
\hline Verbena bracteata* (big-bract verbena) & -- & $\mathrm{X}$ & -- & $\mathrm{X}$ \\
\hline Biotic crust & 0.0 & 0.0 & 0.0 & 0.0 \\
\hline Bare soil & 45.9 & 64.6 & 96.0 & 100.0 \\
\hline Litter & 50.4 & 30.4 & 100.0 & 92.0 \\
\hline Total canopy cover (litter not included) & 62.8 & 58.9 & & \\
\hline \multicolumn{5}{|l|}{ * Invasive species } \\
\hline \multicolumn{5}{|l|}{$\begin{array}{l}X=\text { present but not counted in plot frames } \\
--=\text { species not observed in area }\end{array}$} \\
\hline Total Invasive \% Cover & 42.1 & 43 & & \\
\hline Total Native \% Cover & 20.7 & 15.9 & & \\
\hline Change in Native \% Cover from 2008 & +9.4 & +1.0 & & \\
\hline
\end{tabular}


WCH-428

Rev. 0

\section{Table A-20. Percent Canopy Cover and Frequency of Occurrence at 118-C-1 in 2009.}

\begin{tabular}{lcc}
\multicolumn{1}{c}{ Species } & \% Cover & Freq of Occ \% \\
\hline Agropyron spicatum (bluebunch wheatgrass) & 9.2 & 100.0 \\
Salsola kali* (Russian thistle) & 7.6 & 96.0 \\
Poa sandbergii (Sandberg's bluegrass) & 3.8 & 92.0 \\
Bromus tectorum* (cheatgrass) & 3.5 & 80.0 \\
Sisymbrium altissimum* (tumble mustard) & 0.8 & 32.0 \\
Holosteum umbellatum* (jagged chickweed) & 0.6 & 24.0 \\
Lactuca serriola* (prickly lettuce) & 0.6 & 24.0 \\
Chrysothamnus nauseosus (gray rabbitbrush) & 0.3 & 12.0 \\
Draba verna* (spring whitlow) & 0.2 & 8.0 \\
Epilobium paniculatum (tall willowherb) & 0.2 & 8.0 \\
Erodium cicutarium*(storksbill) & 0.1 & 4.0 \\
Artemisia tridentata (big sagebrush) & 0.1 & 4.0 \\
Sitanion hystrix (bottlebrush squirreltail) & 0.1 & 4.0 \\
Tragopogon dubius* (yellow salsify) & 0.1 & 4.0 \\
Hordeum leporinum (hare barley) & $\mathrm{X}$ & $\mathrm{X}$ \\
Achillea millefolium (yarrow) & $\mathrm{X}$ & $\mathrm{X}$ \\
Biotic crust & 0.0 & 100.0 \\
Bare soil & 50.3 & 100.0 \\
Litter & 52.3 & 100.0 \\
\hline Total canopy cover (litter not included) & 27.2 & \\
* Invasive species & & \\
X=present but not counted in plot frames & & \\
& &
\end{tabular}


Table A-21. Percent Canopy Cover at the Horseshoe Landfill and Soil Staging Area in 2009.

\begin{tabular}{|c|c|c|c|c|}
\hline Species & $\begin{array}{c}\text { HSLF \% } \\
\text { cover }\end{array}$ & $\begin{array}{c}\text { SSA \% } \\
\text { cover }\end{array}$ & $\begin{array}{c}\text { HSLF Freq of } \\
\text { Occ }\end{array}$ & $\begin{array}{l}\text { SSA Freq of } \\
\text { Occ }\end{array}$ \\
\hline Poa sandbergii (Sandberg's bluegrass) & 42.7 & 45.1 & 96.0 & 100.0 \\
\hline Artemisia tridentata (big sagebrush) & 2.3 & 12.3 & 32.0 & 56.0 \\
\hline Bromus tectorum* (cheatgrass) & 10.5 & 11.2 & 92.0 & 96.0 \\
\hline Sisymbrium altissimum* (tumble mustard) & 0.3 & 5.6 & 12.0 & 68.0 \\
\hline Lupinus leucophyllus (velvet lupine) & $\mathrm{X}$ & 1.9 & $\mathrm{X}$ & 20.0 \\
\hline Oryzopsis hymenoides (Indian ricegrass) & 1.8 & -- & 32.0 & -- \\
\hline Crepis artrabarba (slender hawksbeard) & -- & 1.5 & -- & 4.0 \\
\hline Agropyron spicatum (bluebunch wheatgrass) & 1.3 & 0.8 & 32.0 & 12.0 \\
\hline Salsola kali* (Russian thistle) & 1.1 & 1.3 & 44.0 & 52.0 \\
\hline Sitanion hystrix (bottlebrush squirreltail) & 1.1 & $\mathrm{X}$ & 24.0 & $\mathrm{X}$ \\
\hline Amsinckia lycopsoides (tarweed fiddleneck) & -- & 0.5 & -- & 20.0 \\
\hline Machaeranthera canescens (hoary aster) & 0.4 & -- & 16.0 & -- \\
\hline Lactuca serriola* (prickly lettuce) & 0.2 & -- & 8.0 & -- \\
\hline Epilobium paniculatum (tall willowherb) & 0.1 & 0.2 & 4.0 & 8.0 \\
\hline Festuca octoflora (slender sixweeks) & -- & 0.2 & -- & 8.0 \\
\hline Agropyron cristatum (crested wheatgrass) & 0.1 & -- & 4.0 & -- \\
\hline Tragopogon dubius (yellow salsify) & 0.1 & $\mathrm{X}$ & 4.0 & $\mathrm{X}$ \\
\hline Chondrilla juncea (rush skeletonweed) & $\mathrm{X}$ & -- & $\mathrm{X}$ & -- \\
\hline Erigeron filifolius (threadleaf fleabane) & $\mathrm{X}$ & -- & $\mathrm{X}$ & -- \\
\hline Bromus japonicus (Japanese brome) & $\mathrm{X}$ & -- & $\mathrm{X}$ & -- \\
\hline Erigeron piperianus (piper's daisy) & $\mathrm{X}$ & -- & $\mathrm{X}$ & -- \\
\hline Chrysothamnus nauseosus (gray rabbitbrush) & $\mathrm{X}$ & -- & $\mathrm{X}$ & -- \\
\hline Phlox longifolia (longleaf phlox) & -- & $\mathrm{X}$ & -- & $\mathrm{X}$ \\
\hline Achillea millefolium (yarrow) & -- & $\mathrm{X}$ & -- & $\mathrm{X}$ \\
\hline Balsamorhiza careyana (Carey's balsamroot) & -- & $\mathrm{X}$ & -- & $\mathrm{X}$ \\
\hline Biotic crust & 0.0 & 31.0 & 0.0 & 96.0 \\
\hline Bare soil & 75.8 & 39.7 & 100.0 & 100.0 \\
\hline Litter & 14.1 & 38.2 & 100.0 & 100.0 \\
\hline Total canopy cover (litter not included) & 62.0 & 80.6 & & \\
\hline \multicolumn{5}{|l|}{ * Invasive species } \\
\hline \multicolumn{5}{|l|}{$X=$ present but not counted in plot frames } \\
\hline Total Invasive \% Cover & 12.1 & 18.1 & & \\
\hline Total Native \% Cover & 49.9 & 62.5 & & \\
\hline Change in Native \% Cover from 2008 & -11.2 & +0.2 & & \\
\hline
\end{tabular}




\section{Table A-22. Percent Canopy Cover and Frequency of Occurrence at 600-111 in 2009.}

\begin{tabular}{lcc}
\hline \multicolumn{1}{c}{ Species } & \% Cover & Freq of Occ \% \\
\hline Salsola kali* (Russian thistle) & 34.0 & 100.0 \\
Agropyron spicatum (bluebunch wheatgrass) & 15.3 & 100.0 \\
Poa sandbergii (Sandberg's bluegrass) & 13.8 & 100.0 \\
Sisymbrium altissimum* (tumble mustard) & 8.2 & 100.0 \\
Bromus tectorum* (cheatgrass) & 7.8 & 86.7 \\
Draba verna* (spring whitlow) & 0.7 & 26.7 \\
Holosteum umbellatum* (jagged chickweed) & 0.3 & 13.3 \\
Poa bulbosa* (bulbous bluegrass) & 0.3 & 13.3 \\
Sitanion hystrix (bottlebrush squirreltail) & 0.3 & 13.3 \\
Achillea millefolium (yarrow) & 0.2 & 6.7 \\
Artemisia tridentata (big sagebrush) & 0.2 & 6.7 \\
Ambrosia acanthicarpa (bur ragweed) & 0.2 & 6.7 \\
Polemonium micranthum (annual Jacob's ladder) & $\mathrm{X}$ & $\mathrm{X}$ \\
Chenopodium leptophyllum*(slimleaf goosefoot) & $\mathrm{X}$ & $\mathrm{X}$ \\
Melilotus alba* (white sweetclover) & $\mathrm{X}$ & $\mathrm{X}$ \\
Descurainia pinnata (western tansymustard) & $\mathrm{X}$ & $\mathrm{X}$ \\
Lepidium perfoliatum*(clasping pepperweed) & $\mathrm{X}$ & $\mathrm{X}$ \\
Triticum aestivum*(wheat) & $\mathrm{X}$ & $\mathrm{X}$ \\
Stipa comata (needle-and-thread grass) & $\mathrm{X}$ & $\mathrm{X}$ \\
Biotic crust & 0.0 & 0.0 \\
Bare soil & 56.8 & 100.0 \\
Litter & 41.5 & 100.0 \\
\hline Total canopy cover (litter not ins & 81.3 & \\
\hline
\end{tabular}

Total canopy cover (litter not included)

81.3

* Invasive species

$\mathrm{X}=$ present but not counted in plot frames

Total Invasive \% Cover $\quad 51.3$

Total Native \% Cover $\quad 30.0$ 


\section{Table A-23. Percent Canopy Cover and Frequency} of Occurrence at 600-149 in 2009.

\begin{tabular}{lcc}
\hline \multicolumn{1}{c}{ Species } & \% Cover & Freq of Occ \% \\
\hline Agropyron spicatum (bluebunch wheatgrass) & 29.5 & 100.0 \\
Poa sandbergii (Sandberg's bluegrass) & 17.8 & 100.0 \\
Salsola kali* (Russian thistle) & 13.7 & 93.3 \\
Sisymbrium altissimum* (tumble mustard) & 4.3 & 73.3 \\
Sitanion hystrix (bottlebrush squirreltail) & 1.5 & 60.0 \\
Bromus tectorum* (cheatgrass) & 1.2 & 46.7 \\
Draba verna*(spring whitlow) & 1.2 & 46.7 \\
Chenopodium album* (lamb's quarters) & 0.3 & 13.3 \\
Melilotus alba*(white sweetclover) & 0.3 & 13.3 \\
Plantago patagonica (Indian wheat) & 0.2 & 6.7 \\
Lactuca serriola*(prickly lettuce) & 0.2 & 6.7 \\
Chorispora tenella*(blue mustard) & $\mathrm{X}$ & $\mathrm{X}$ \\
Descurainia pinnata (western tansymustard) & $\mathrm{X}$ & $\mathrm{X}$ \\
Vulpia myuros* (rattail fescue) & $\mathrm{X}$ & $\mathrm{X}$ \\
Artemisia tridentata (big sagebrush) & $\mathrm{X}$ & $\mathrm{X}$ \\
Grayia spinosa (spiny hopsage) & $\mathrm{X}$ & $\mathrm{X}$ \\
Biotic crust & 0.0 & 0.0 \\
Bare soil & 45.8 & 100.0 \\
Litter & 50.7 & 100.0 \\
\hline
\end{tabular}

Total canopy cover (litter not included) 70.2

* Invasive species

$\mathrm{X}=$ present but not counted in plot frames

Total Invasive \% Cover 21.2

Total Native \% Cover $\quad 49.0$ 
WCH-428

Rev. 0 


\section{APPENDIX B}

\section{REVEGETATION MONITORING RESULTS}


WCH-428

Rev. 0 
Table B-1. Percent Canopy Cover and Frequency of Occurrence at the 300-FF-1 Process Ponds in 2008.

\begin{tabular}{|c|c|c|}
\hline Species & \% Cover & Freq of Occ \% \\
\hline Bromus tectorum* (cheatgrass) & 37.6 & 94.3 \\
\hline Agropyron spicatum (bluebunch wheatgrass) & 26.9 & 82.9 \\
\hline Poa sandbergii (Sandberg's bluegrass) & 18.1 & 82.9 \\
\hline Agropyron cristatum* (Crested Wheatgrass) & 11.4 & 48.6 \\
\hline Salsola kali* (Russian thistle) & 4.0 & 91.4 \\
\hline Vulpia myuros* (rattail fescue) & 2.2 & 20.0 \\
\hline Erodium cicutarium* (storksbill) & 1.9 & 62.9 \\
\hline Descurainia pinnata (western tansymustard) & 1.1 & 5.7 \\
\hline Centaurea diffusa* (diffuse knapweed) & 0.6 & 11.4 \\
\hline Holosteum umbellatum* (jagged chickweed) & 0.3 & 11.4 \\
\hline Epilobium paniculatum (tall willowherb) & 0.3 & 11.4 \\
\hline Machaeranthera canescens (hoary aster) & 0.2 & 8.6 \\
\hline Sisymbrium altissimum* (tumble mustard) & 0.1 & 5.7 \\
\hline Amsinckia lycopsoides (tarweed fiddleneck) & 0.1 & 2.9 \\
\hline Agropyron dasytachyum (thickspike wheatgrass) & 0.1 & 2.9 \\
\hline Hordeum leporinum* (hare barley) & 0.1 & 2.9 \\
\hline Lactuca serriola* (prickly lettuce) & 0.1 & 2.9 \\
\hline Chondrilla juncea* (rush skeletonweed) & 0.1 & 2.9 \\
\hline Melilotus officinalis* (sweetclover) & 0.1 & 2.9 \\
\hline Tragopogon dubius* (yellow salsify) & 0.1 & 2.9 \\
\hline Malva neglecta* (cheeseweed) & 0.1 & 2.9 \\
\hline Petalostemon ornatum (prairie clover) & $\mathrm{X}$ & $\mathrm{X}$ \\
\hline Taraxacum officinale* (common dandelion) & $\mathrm{X}$ & $\mathrm{X}$ \\
\hline Erigeron filifolius (threadleaf fleabane) & $\mathrm{X}$ & $\mathrm{X}$ \\
\hline Lepidium perfoliatum (clasping pepperweed) & $\mathrm{X}$ & $\mathrm{X}$ \\
\hline Achillea millefolium (yarrow) & $\mathrm{X}$ & $\mathrm{X}$ \\
\hline Oryzopsis hymenoides (Indian ricegrass) & $\mathrm{X}$ & $\mathrm{X}$ \\
\hline Sphaeralcea munroana (globemallow) & $\mathrm{X}$ & $\mathrm{X}$ \\
\hline Chrysothamnus nauseosus (gray rabbitbrush) & $\mathrm{X}$ & $\mathrm{X}$ \\
\hline Astragalus caricinus (buckwheat milkvetch) & $\mathrm{X}$ & $\mathrm{X}$ \\
\hline Cardaria draba * (whitetop) & $\mathrm{X}$ & $\mathrm{X}$ \\
\hline Hymenopappus filifolius (Columbia cutleaf) & $\mathrm{X}$ & $\mathrm{X}$ \\
\hline Biotic crust & 10.8 & 60.0 \\
\hline Bare Soil & 46.9 & 97.1 \\
\hline Litter & 42.6 & 100.0 \\
\hline
\end{tabular}

Total canopy cover (litter not included)

105.4

* Introduced species.

$\mathrm{X}=$ Species present on the site but not counted in a plot frame.

Total Introduced \% Cover 2008

Total Native \% Cover 2008

Change in Native Plant \% Cover from 2007 to $2008+12.3$ 
Table B-2. Percent Canopy Cover and Frequency of Occurrence at $618-2$ and $618-3$ in 2008.

\begin{tabular}{lcc}
\hline \multicolumn{1}{c}{ Species } & \% Cover & Freq of Occ \% \\
\hline Agropyron cristatum* (crested wheatgrass) & 21.7 & 100.0 \\
Bromus tectorum* (cheatgrass) & 15.3 & 93.3 \\
Agropyron spicatum (bluebunch wheatgrass) & 4.7 & 86.7 \\
Poa sandbergii (Sandberg's bluegrass) & 3.2 & 93.3 \\
Salsola kali* (Russian thistle) & 2.2 & 86.7 \\
Chrysothamnus nauseosus (gray rabbitbrush) & 0.2 & 6.7 \\
Oryzopsis hymenoides (Indian ricegrass) & 0.2 & 6.7 \\
Centaurea diffusa* (diffuse knapweed) & 0.2 & 6.7 \\
Sisymbrium altissimum* (tumble mustard) & 0.2 & 6.7 \\
Epilobium paniculatum (tall willowherb) & 0.2 & 6.7 \\
Amsinckia lycopsoides (tarweed fiddleneck) & $\mathrm{X}$ & $\mathrm{X}$ \\
Ambrosia acanthicarpa (bur ragweed) & $\mathrm{X}$ & $\mathrm{X}$ \\
Lactuca serriola* (prickly lettuce) & $\mathrm{X}$ & $\mathrm{X}$ \\
Machaeranthera canescens (hoary aster) & $\mathrm{X}$ & $\mathrm{X}$ \\
Agropyron dasytachyum (thickspike wheatgrass) & $\mathrm{X}$ & $\mathrm{X}$ \\
Eriogonum niveum (snow buckwheat) & $\mathrm{X}$ & $\mathrm{X}$ \\
Achillea millefolium (yarrow) & $\mathrm{X}$ & $\mathrm{X}$ \\
Biotic crust & 0.0 & 0.0 \\
Bare Soil & 46.7 & 93.3 \\
Litter & 46.8 & 100.0 \\
\hline
\end{tabular}

Total canopy cover (litter not included) 47.8

* Invasive species

$\mathrm{X}=$ present but not counted in plot frames

Total Invasive \% Cover 39.5

Total Native \% Cover 8.3

Total Change in Native Cover from $2007 \quad-3.4$ 
WCH-428

Rev. 0

Table B-3. Percent Canopy Cover and Frequency of Occurrence at 300-8 in 2008.

\begin{tabular}{lcc}
\hline \multicolumn{1}{c}{ Species } & \% Cover & Freq of Occ \% \\
\hline Bromus tectorum* (cheatgrass) & 37.6 & 96.0 \\
Agropyron cristatum* (crested wheatgrass) & 16.4 & 96.0 \\
Salsola kali* (Russian thistle) & 3.9 & 96.0 \\
Holosteum umbellatum* (jagged chickweed) & 2.3 & 52.0 \\
Festuca octoflora (slender sixweeks) & 1.9 & 20.0 \\
Oenothera pallida (evening primrose) & 1.5 & 4.0 \\
Poa sandbergii (Sandberg's bluegrass) & 1.4 & 56.0 \\
Chrysothamnus nauseosus (gray rabbitbrush) & 1.0 & 20.0 \\
Draba verna* (spring whitlowgrass) & 0.9 & 36.0 \\
Machaeranthera canescens (hoary aster) & 0.4 & 16.0 \\
Erodium cicutarium*(storksbill) & 0.3 & 12.0 \\
Oryzopsis hymenoides (Indian ricegrass) & 0.2 & 8.0 \\
Agropyron spicatum (bluebunch wheatgrass) & 0.2 & 8.0 \\
Poa bulbosa* (bulbous bluegrass) & 0.1 & 4.0 \\
Amsinckia lycopsoides (tarweed fiddleneck) & $\mathrm{X}$ & $\mathrm{X}$ \\
Chondrilla juncea* (rush skeletonweed) & $\mathrm{X}$ & $\mathrm{X}$ \\
Crepis atrabarba (slender hawksbeard) & $\mathrm{X}$ & $\mathrm{X}$ \\
Centaurea diffusa* (diffuse knapweed) & $\mathrm{X}$ & $\mathrm{X}$ \\
Sisymbrium altissimum* (tumble mustard) & $\mathrm{X}$ & $\mathrm{X}$ \\
Stipa comata (needle-and-thread grass) & $\mathrm{X}$ & $\mathrm{X}$ \\
Artemisia tridentata (sagebrush) & $\mathrm{X}$ & $\mathrm{X}$ \\
Biotic crust & 0.0 & 0.0 \\
Bare Soil & 58.5 & 96.0 \\
Litter & 34.9 & 100.0 \\
\hline Total cant & 68.1 &
\end{tabular}

Total canopy cover (litter not included)

68.1

* Invasive species

$\mathrm{X}=$ present but not counted in plot frames

Total Invasive \% Cover

61.5

Total Native \% Cover

6.6

Change in Native Cover from 2007

$-33.5$ 
Table B-4. Percent Canopy Cover and Frequency of Occurrence at the Hanford Generating Plant West Cobble and East Topsoil Sites in 2008.

\begin{tabular}{|c|c|c|c|c|}
\hline Species & $\begin{array}{l}\text { \% Cover } \\
\text { E. Topsoil }\end{array}$ & $\begin{array}{c}\text { \% Cover } \\
\text { W. Cobble }\end{array}$ & $\begin{array}{c}\text { Freq of Occ \% } \\
\text { E. Topsoil } \\
\end{array}$ & $\begin{array}{c}\text { Freq of Occ \% } \\
\text { W. Cobble }\end{array}$ \\
\hline Poa sandbergii (Sandberg's bluegrass) & 47.3 & 47.0 & 88.0 & 100.0 \\
\hline Bromus tectorum* (cheatgrass) & 45.2 & 15.8 & 100.0 & 80.0 \\
\hline Holosteum umbellatum* (jagged chickweed) & 43.2 & 8.6 & 92.0 & 40.0 \\
\hline Chorispora tenella* (blue mustard) & 6.1 & -- & 56.0 & -- \\
\hline Agropyron Spp. & -- & 4.7 & -- & 36.0 \\
\hline Ranunculus testiculatus* (bur buttercup) & 3.4 & -- & 40.0 & -- \\
\hline Sisymbrium altissimum* (tumble mustard) & 1.1 & 0.7 & 44.0 & 28.0 \\
\hline Centaurea diffusa* (diffuse knapweed) & 0.9 & 0.5 & 16.0 & 20.0 \\
\hline Sitanion hystrix (bottlebrush squirreltail) & 0.2 & 3.4 & 8.0 & 40.0 \\
\hline Salsola kali* (Russian thistle) & 0.4 & 1.6 & 16.0 & 64.0 \\
\hline Chrysothamnus nauseosus (gray rabbitbrush) & 0.1 & 1.6 & 4.0 & 8.0 \\
\hline Draba verna* (spring whitlow) & $\mathrm{X}$ & 1.5 & $\mathrm{X}$ & 20.0 \\
\hline Agropyron spicatum (bluebunch wheatgrass) & 0.8 & -- & 12.0 & -- \\
\hline Amsinckia lycopsoides (tarweed fiddleneck) & 0.5 & -- & 20.0 & -- \\
\hline Erodium cicutarium* (storksbill) & -- & 0.4 & -- & 16.0 \\
\hline Festuca octoflora (six-weeks fescue) & -- & 0.4 & -- & 16.0 \\
\hline Microsteris gracilis (annual phlox) & -- & 0.4 & -- & 16.0 \\
\hline Artemesia tridentata (sagebrush) & 0.2 & 0.3 & 8.0 & 12.0 \\
\hline Descurainia pinnata (western tansymustard) & -- & 0.2 & -- & 8.0 \\
\hline Achillea millefolium (yarrow) & 0.1 & 0.2 & 4.0 & 8.0 \\
\hline Chorispora tenella* (blue mustard) & -- & 0.1 & -- & 4.0 \\
\hline Poa bulbosa* (bulbous bluegrass) & -- & 0.1 & -- & 4.0 \\
\hline Machaeranthera canescens (hoary aster) & -- & $\mathrm{X}$ & -- & $\mathrm{X}$ \\
\hline Agropyron dasytachyum (thickspike & & & & \\
\hline wheatgrass) & -- & X & -- & $\mathrm{X}$ \\
\hline Verbascum thapsus * (common mullein) & -- & $\mathrm{X}$ & -- & $\mathrm{X}$ \\
\hline Biotic Crust & 0.0 & 0.0 & 0.0 & 0.0 \\
\hline Bare Soil & 19.2 & 45.9 & 84.0 & 96.0 \\
\hline Litter & 84.5 & 53.6 & 100.0 & 100.0 \\
\hline Total canopy cover (litter not included) & 149.5 & 87.5 & & \\
\hline \multicolumn{5}{|l|}{ * Invasive species } \\
\hline \multicolumn{5}{|l|}{$X=$ present but not counted in plot frames } \\
\hline Total Invasive \% Cover & 100.3 & 29.3 & & \\
\hline Total Native \% Cover & 49.2 & 58.2 & & \\
\hline Change in Native Cover \% from 2007 to 2008 & -36.6 & +20.2 & & \\
\hline
\end{tabular}


Table B-5. Percent Canopy Cover and Frequency of Occurrence at 116-N-1 in 2008.

\begin{tabular}{lcc}
\hline \multicolumn{1}{c}{ Species } & \% Cover & Freq of Occ \% \\
\hline Poa sandbergii (Sandberg's bluegrass) & 40.5 & 96 \\
Agropyron spicatum (bluebunch wheatgrass) & 6.5 & 68 \\
Salsola kali* (Russian thistle) & 5 & 84 \\
Sisymbrium altissimum* (tumble mustard) & 1.9 & 76 \\
Bromus tectorum* (cheatgrass) & 1.9 & 76 \\
Artemesia tridentata (sagebrush) & 1.2 & 28 \\
Oryzopsis hymenoides (Indian ricegrass) & 0.3 & 12 \\
Descurainia pinnata (western tansymustard) & 0.3 & 12 \\
Chrysothamnus nauseosus (gray rabbitbrush) & 0.1 & 4 \\
Epilobium paniculatum (tall willowherb) & 0.1 & 4 \\
Achillea millefolium (yarrow) & 0.1 & 4 \\
Lactuca seriola* (prickly lettuce) & 0.1 & 4 \\
Centaurea diffusa * (diffuse knapweed) & $\mathrm{X}$ & $\mathrm{X}$ \\
Tragopogon dubius * (yellow salsify) & $\mathrm{X}$ & $\mathrm{X}$ \\
Biotic crust & 0 & 0 \\
Bare Soil & 38.5 & 92 \\
Litter & 64.1 & 100 \\
\hline
\end{tabular}

Total canopy cover (litter not included) 58.0

* Invasive species

$\mathrm{X}=$ present but not counted in plot frames

Total Invasive \% Cover

Total Native \% Cover

49.1

Change in Native Cover \% from 2007

$+16.43$ 
Table B-6. Percent Canopy Cover and Frequency of Occurrence at 116-N-3 in 2008.

\begin{tabular}{lcc}
\hline \multicolumn{1}{c}{ Species } & \% Cover & Freq of Occ \% \\
\hline Poa sandbergii (Sandberg's bluegrass) & 33.0 & 88.0 \\
Bromus tectorum* (cheatgrass) & 20.3 & 84.0 \\
Agropyron spicatum (bluebunch wheatgrass) & 9.9 & 52.0 \\
Salsola kali* (Russian thistle) & 4.2 & 92.0 \\
Holosteum umbellatum* (jagged chickweed) & 1.5 & 20.0 \\
Sitanion hystrix (bottlebrush squirreltail) & 1.5 & 4.0 \\
Sisymbrium altissimum* (tumblemustard) & 1.0 & 40.0 \\
Lactuca serriola* (prickly lettuce) & 0.4 & 16.0 \\
Centaurea diffusa* (diffuse knapweed) & 0.3 & 12.0 \\
Amsinckia lycopsoides (tarweed fiddleneck) & 0.2 & 8.0 \\
Draba verna* (spring whitlowgrass) & 0.1 & 4.0 \\
Epilobium paniculatum (tall willowherb) & 0.1 & 4.0 \\
Oryzopsis hymenoides (Indian ricegrass) & $\mathrm{X}$ & $\mathrm{X}$ \\
Melilotus alba* (sweetclover) & $\mathrm{X}$ & $\mathrm{X}$ \\
Artemisia tridentata (big sagebrush) & $\mathrm{X}$ & $\mathrm{X}$ \\
Chrysothamnus nauseosus (gray rabbitbrush) & $\mathrm{X}$ & $\mathrm{X}$ \\
Machaeranthera canescens (hoary aster) & $\mathrm{X}$ & $\mathrm{X}$ \\
Biotic crust & 0.0 & 0.0 \\
Bare soil & 53.3 & 100.0 \\
Litter & 31.9 & 92.0 \\
\hline Total canopy cover (litter not included) & 72.5 & \\
* Invasive species & & \\
X=present but not counted in plot frames & & \\
& & \\
Total Invasive \% Cover & 27.8 & \\
Total Native \% Cover & 44.7 & \\
Change in Native Cover from 2007 & +6.7 & \\
\end{tabular}


Table B-7. Percent Canopy Cover and Frequency of Occurrence at 100-F Area Sites in 2008.

\begin{tabular}{|c|c|c|}
\hline Species & \% Cover & Freq of Occ \% \\
\hline Bromus tectorum* (cheatgrass) & 53.9 & 100.0 \\
\hline Poa sandbergii (Sandberg's bluegrass) & 28.9 & 94.3 \\
\hline Agropyron spicatum (bluebunch wheatgrass) & 11.8 & 71.4 \\
\hline Salsola kali* (Russian thistle) & 2.4 & 82.9 \\
\hline Achillea millefolium (yarrow) & 2.3 & 8.6 \\
\hline Oryzopsis hymenoides (Indian ricegrass) & 1.4 & 17.1 \\
\hline Chrysothamnus nauseosus (gray rabbitbrush) & 1.1 & 5.7 \\
\hline Holosteum umbellatum* (jagged chickweed) & 0.7 & 14.3 \\
\hline Artemesia tridentata (sagebrush) & 0.5 & 5.7 \\
\hline Agropyron dasytachyum (thickspike wheatgrass) & 0.4 & 2.9 \\
\hline Erodium cicutarium* (storksbill) & 0.3 & 11.4 \\
\hline Draba verna* (spring whitlow) & 0.3 & 11.4 \\
\hline Sitanion hystrix (bottlebrush squirreltail) & 0.1 & 2.9 \\
\hline Sisymbrium altissimum* (tumble mustard) & 0.1 & 2.9 \\
\hline Lepidium perfoliatum* (clasping pepperweed) & 0.1 & 2.9 \\
\hline Centaurea diffusa $*$ (diffuse knapweed) & $\mathrm{X}$ & $\mathrm{X}$ \\
\hline Chrysothamnus viscidiflorus (green rabbitbrush) & $\mathrm{X}$ & $\mathrm{X}$ \\
\hline Agoseris heterophylla (mountain dandelion) & $\mathrm{X}$ & $\mathrm{X}$ \\
\hline Amsinckia lycopsoides (tarweed fiddleneck) & $\mathrm{X}$ & $\mathrm{X}$ \\
\hline Sporobolus cryptandrus (sanddrop seed) & $\mathrm{X}$ & $\mathrm{X}$ \\
\hline Machaeranthera canescens (hoary aster) & $\mathrm{X}$ & $\mathrm{X}$ \\
\hline Astragalus sclerocarpus (stalk-pod milkvetch) & $\mathrm{X}$ & $\mathrm{X}$ \\
\hline Astragalus caricinus (buckwheat milkvetch) & $\mathrm{X}$ & $\mathrm{X}$ \\
\hline Astragalus succumbens (crouching milkvetch) & $\mathrm{X}$ & $\mathrm{X}$ \\
\hline Lactuca seriola* (prickly lettuce) & $\mathrm{X}$ & $\mathrm{X}$ \\
\hline Vicia cracca* (bird vetch) & $\mathrm{X}$ & $\mathrm{X}$ \\
\hline Koeleria cristata (prairie junegrass) & $\mathrm{X}$ & $\mathrm{X}$ \\
\hline Tragopogon dubius * (yellow salsify) & $\mathrm{X}$ & $\mathrm{X}$ \\
\hline Poa bulbosa* (bulbous bluegrass) & $\mathrm{X}$ & $\mathrm{X}$ \\
\hline Ambrosia acanthicarpa (bur ragweed) & $\mathrm{X}$ & $\mathrm{X}$ \\
\hline Biotic crust & 1.4 & 28.6 \\
\hline Bare Soil & 28.5 & 94.3 \\
\hline Litter & 64.4 & 100.0 \\
\hline
\end{tabular}

Total canopy cover (litter not included) 104.3

* Introduced species.

$\mathrm{X}=$ Species present on the site but not counted in a plot frame.

Total Introduced \% Cover 2008

Total Native \% Cover 2008

Change in Native Plant \% Cover from 2007 to $2008 \quad+8.9$ 
WCH-428

Rev. 0

Table B-8. Percent Canopy Cover and Frequency of Occurrence at the 118-F-1 Burial Ground in 2008.

\begin{tabular}{lcc}
\hline \multicolumn{1}{c}{ Species } & \% Cover & Freq of Occ \% \\
\hline Native Grasses $^{\mathrm{b}}$ & 3.5 & 100.0 \\
Salsola kali* (Russian thistle) $^{*}$ & 2.8 & 56.0 \\
Artemesia tridentata (sagebrush) $_{\text {Chrysothamnus nauseosus (gray rabbitbrush) }}$ & 0.2 & 8.0 \\
Erodium cicutarium* (storksbill) $_{\text {Bromus tectorum* (cheatgrass) }}$ & $\mathrm{X}$ & $\mathrm{X}$ \\
Lactuca serriola $^{*}$ (prickly lettuce) & $\mathrm{X}$ & $\mathrm{X}$ \\
Grayia spinosa (hopsage) & $\mathrm{X}$ & $\mathrm{X}$ \\
Sisymbrium altissimum* (tumble mustard) & $\mathrm{X}$ & $\mathrm{X}$ \\
Poa bulbosa* (bulbous bluegrass) $_{\text {Biotic crust }}$ & $\mathrm{X}$ & $\mathrm{X}$ \\
Bare soil & $\mathrm{X}$ & $\mathrm{X}$ \\
Litter & 0 & $\mathrm{X}$ \\
\hline
\end{tabular}

Total canopy cover (litter not included)

6.5

* Invasive species

$\mathrm{X}=$ present but not counted in plot frames

bIncludes Sandberg's bluegrass, bluebunch wheatgrass, thickspike wheatgrass, Indian ricegrass, needle-and-thread grass, and prairie junegrass seedlings.

Total Invasive \% Cover

2.8

Total Native \% Cover 
Table B-9. Percent Canopy Cover and Frequency of Occurrence at 118-F-2 in 2008.

\begin{tabular}{lcc}
\hline \multicolumn{1}{c}{ Species } & \% Cover & Freq of Occ \% \\
\hline Native Grasses $^{\mathrm{b}}$ & 18.7 & 96.0 \\
Salsola kali* (Russian thistle) $_{\text {Nama densum (purplemat) }}$ & 9.5 & 88.0 \\
Amsinckia lycopsoides (tarweed fiddleneck) & 0.1 & 4.0 \\
Sisymbrium altissimum* (tumble mustard) $_{\text {Lactuca serriola* (prickly lettuce) }}$ & 0.1 & 4.0 \\
Bromus tectorum* (cheatgrass) $_{\text {Poa bulbosa* (bulbous bluegrass) }}$ & 2.6 & 28.0 \\
Artemesia tridentata (sagebrush) & 0.1 & 4.0 \\
Descurainia pinnata (western tansymustard) & 4.2 & 16.0 \\
Grayia spinosa (Spiny hopsage) & 0.2 & 8.0 \\
Draba verna* (spring whitlow) & 0.1 & 4.0 \\
Chrysothamnus nauseosus (gray rabbitbrush) & 0.1 & 4.0 \\
Holosteum umbellatum* (jagged chickweed) & 0.1 & 4.0 \\
Cardaria draba* (whitetop) & 0.1 & 4.0 \\
Vicia cracca* (bird vetch) & $\mathrm{X}$ & $\mathrm{X}$ \\
Lepidium perfoliatum (clasping pepperweed) & $\mathrm{X}$ & $\mathrm{X}$ \\
Biotic Crust & $\mathrm{X}$ & $\mathrm{X}$ \\
Bare Soil & $\mathrm{X}$ & $\mathrm{X}$ \\
Litter & $\mathrm{X}$ & $\mathrm{X}$ \\
\hline
\end{tabular}

Total canopy cover (litter not included)

* Invasive species

$\mathrm{X}=$ present but not counted in plot frames

${ }^{b}$ Includes Sandberg's bluegrass, bluebunch wheatgrass, thickspike wheatgrass, Indian ricegrass, needle-andthread grass, and prairie junegrass seedlings.

Total Invasive \% Cover

16.7

Total Native \% Cover 
Table B-10. Percent Canopy Cover and Frequency of Occurrence at 182-F North and South in 2008.

\begin{tabular}{lcccc}
\hline \multicolumn{1}{c}{ Species } & $\begin{array}{c}\text { \% Cover } \\
\text { North }\end{array}$ & $\begin{array}{c}\text { \% Cover } \\
\text { South }\end{array}$ & $\begin{array}{c}\text { Freq of Occ } \\
\text { \% North }\end{array}$ & $\begin{array}{c}\text { Freq of Occ } \\
\text { \% South }\end{array}$ \\
\hline Native Grasses $^{\mathrm{b}}$ & 47.2 & 35.2 & 100.0 & 100.0 \\
Bromus tectorum* (cheatgrass) $_{\text {Salsola } \text { kali* (Russian thistle) }}$ & 17.7 & 33.8 & 73.3 & 96.0 \\
Sisymbrium altissimum* (tumble mustard) & 1.2 & 29.4 & 46.7 & 92.0 \\
Poa bulbosa* (Bulbous bluegrass) & 0.3 & 2.4 & 13.3 & 56.0 \\
Draba verna*(spring whitlowgrass) & 1.3 & 1.2 & 20.0 & 28.0 \\
Artemesia tridentata (sagebrush) & 0.2 & 0.4 & 6.7 & 16.0 \\
Erodium cicutarium*(storksbill) & 0.2 & 0.1 & 6.7 & 4.0 \\
Sporobolus cryptandrus (sanddrop seed) & -- & 0.9 & -- & 16.0 \\
Verbena bracteata (big-bract verbena) & $\mathrm{X}$ & 0.6 & $\mathrm{X}$ & 4.0 \\
Vicia cracca* (bird vetch) & -- & 0.1 & -- & 4.0 \\
Achillea millefolium (yarrow) & -- & 0.1 & -- & 4.0 \\
Triticum aestivum* (wheat) & -- & $\mathrm{X}$ & -- & $\mathrm{X}$ \\
Artemisia ludoviciana (white sagebrush) & -- & $\mathrm{X}$ & -- & $\mathrm{X}$ \\
Centaurea diffusa* (diffuse knapweed) & $\mathrm{X}$ & $\mathrm{X}$ & $\mathrm{X}$ & $\mathrm{X}$ \\
Chrysothamnus nauseosus (gray rabbitbrush) & $\mathrm{X}$ & $\mathrm{X}$ & $\mathrm{X}$ & $\mathrm{X}$ \\
Sphaeralcea munroana (globemallow) & $\mathrm{X}$ & $\mathrm{X}$ & $\mathrm{X}$ & $\mathrm{X}$ \\
Astragalus succumbens (Columbia milk-vetch) & -- & $\mathrm{X}$ & -- & $\mathrm{X}$ \\
Lactuca seriola* (prickly lettuce) & -- & $\mathrm{X}$ & -- & $\mathrm{X}$ \\
Machaeranthera canescens (hoary aster) & -- & $\mathrm{X}$ & -- & $\mathrm{X}$ \\
Astragalus spp. & $\mathrm{X}$ & $\mathrm{X}$ & $\mathrm{X}$ & $\mathrm{X}$ \\
Melilotus alba * (sweetclover) & $\mathrm{X}$ & $\mathrm{X}$ & $\mathrm{X}$ & $\mathrm{X}$ \\
Biotic crust & $\mathrm{X}$ & -- & $\mathrm{X}$ & -- \\
Bare soil & 0.0 & 0.0 & 0.0 & 0.0 \\
Litter & 20.5 & 16.8 & 80.0 & 80.0 \\
\hline Total canopy cover (litter not & 75.8 & 75.9 & 100.0 & 100.0 \\
\hline
\end{tabular}

Total canopy cover (litter not included)

* Invasive species

$\mathrm{X}=$ present but not counted in plot frames

-- species not recorded

${ }^{\mathrm{b}}$ Includes Sandberg's bluegrass, bluebunch wheatgrass, thickspike wheatgrass, Indian ricegrass, needle-and-thread grass, and prairie junegrass seedlings.

Total Invasive \% Cover

$20.7 \quad 68.2$

Total Native \% Cover 
WCH-428

Rev. 0

Table B-11. Percent Canopy Cover and Frequency of Occurrence at the 183-F East Clearwell in 2008.

\begin{tabular}{|c|c|c|}
\hline Species & \% Cover & Freq of Occ \% \\
\hline Native grasses ${ }^{b}$ & 52.3 & 100.0 \\
\hline Bromus tectorum* (cheatgrass) & 1.3 & 20.0 \\
\hline Salsola kali* (Russian thistle) & 6.7 & 100.0 \\
\hline Ranunculus testiculatus* (bur buttercup) & 1.5 & 26.7 \\
\hline Grayia spinosa (hopsage) & 0.2 & 6.7 \\
\hline Festuca octoflora (slender sixweeks) & 0.2 & 6.7 \\
\hline Astragalus succumbens (Columbia milk-vetch) & 0.2 & 6.7 \\
\hline Erodium cicutarium* (storksbill) & 0.2 & 6.7 \\
\hline Poa bulbosa* (bulbous bluegrass) & 0.2 & 6.7 \\
\hline Nama densum (purplemat) & 0.2 & 6.7 \\
\hline Cryptantha circumscissa (matted cryptantha) & 0.2 & 6.7 \\
\hline Chrysothamnus nauseosus (gray rabbitbrush) & 0.2 & 6.7 \\
\hline Sisymbrium altissimum* (tumble mustard) & 0.3 & 13.3 \\
\hline Artemisia tridentata (big sagebrush) & 0.2 & 6.7 \\
\hline Lactuca serriola* (prickly lettuce) & 0.2 & 6.7 \\
\hline Chorispora tenella* (blue mustard) & $\mathrm{X}$ & $\mathrm{X}$ \\
\hline Amsinckia lycopsoides (tarweed fiddleneck) & $\mathrm{X}$ & $\mathrm{X}$ \\
\hline Biotic crust & 0.0 & 0.0 \\
\hline Bare soil & 45.2 & 100.0 \\
\hline Litter & 46.0 & 100.0 \\
\hline
\end{tabular}

Total canopy cover (litter not included)

63.8

* Invasive species

$\mathrm{X}=$ present but not counted in plot frames

${ }^{\mathrm{b}}$ Includes Sandberg's bluegrass, bluebunch wheatgrass, thickspike wheatgrass, Indian ricegrass, needle-and-thread grass, and prairie junegrass seedlings.

Total Invasive \% Cover $\quad 10.3$

Total Native \% Cover 53.5 
Table B-12. Percent Canopy Cover and Frequency of Occurrence at 100-F-26 in 2008.

\begin{tabular}{lcc}
\hline \multicolumn{1}{c}{ Species } & \% Cover & Freq of Occ \% \\
\hline Native grasses $^{\mathrm{b}}$ & 22.7 & 86.7 \\
Bromus tectorum* (cheatgrass) & 16.2 & 73.3 \\
Salsola kali* (Russian thistle) $_{\text {Festuca octoflora (slender sixweeks) }}$ & 16.3 & 100.0 \\
Sisymbrium altissimum* (tumble mustard) & 0.2 & 6.7 \\
Chenopodium album (lambsquarters) & 0.7 & 26.7 \\
Artemisia tridentata (big sagebrush) & 0.3 & 13.3 \\
Erodium cicutarium* (storksbill) & 0.2 & 6.7 \\
Chorispora tenella* (blue mustard) & 0.2 & 6.7 \\
Lepidium perfoliatum (clasping pepperweed) & 0.2 & 6.7 \\
Amsinckia lycopsoides (tarweed fiddleneck) & $\mathrm{X}$ & $\mathrm{X}$ \\
Poa bulbosa* (bulbous bluegrass) & $\mathrm{X}$ & $\mathrm{X}$ \\
Ranunculus testiculatus* (bur buttercup) & $\mathrm{X}$ & $\mathrm{X}$ \\
Achillea millefolium (yarrow) & $\mathrm{X}$ & $\mathrm{X}$ \\
Chrysothamnus nauseosus (gray rabbitbrush) & $\mathrm{X}$ & $\mathrm{X}$ \\
Sphaeralcea munroana (Munro's globemallow) & $\mathrm{X}$ & $\mathrm{X}$ \\
Grayia spinosa (hopsage) & $\mathrm{X}$ & $\mathrm{X}$ \\
Centaurea diffusa* (diffuse knapweed) & $\mathrm{X}$ & $\mathrm{X}$ \\
Biotic crust & $\mathrm{X}$ & $\mathrm{X}$ \\
Bare soil & 0.0 & 0.0 \\
Litter & 41.3 & 100.0 \\
\hline
\end{tabular}

Total canopy cover (litter not included)

* Invasive species

$\mathrm{X}=$ present but not counted in plot frames

${ }^{b}$ Includes Sandberg's bluegrass, bluebunch wheatgrass, thickspike wheatgrass, Indian ricegrass, needle-and-thread grass, and prairie junegrass seedlings.

Total Invasive \% Cover

Total Native \% Cover 
WCH-428

Rev. 0

Table B-13. Percent Canopy Cover and Frequency of Occurrence at 118-F-5 Soil Staging Area and Burial Ground in 2008.

\begin{tabular}{|c|c|c|c|c|}
\hline Species & $\begin{array}{c}\text { \% Cover } \\
\text { SSA } \\
\end{array}$ & $\begin{array}{c}\text { \% Cover } \\
\text { BG } \\
\end{array}$ & $\begin{array}{c}\text { Freq of Occ } \\
\% \text { SSA } \\
\end{array}$ & $\begin{array}{c}\text { Freq of Occ } \\
\% \text { BG } \\
\end{array}$ \\
\hline Bromus tectorum* (cheatgrass) & 49.2 & 13.5 & 100.0 & 93.3 \\
\hline Native Grasses ${ }^{\mathrm{b}}$ & 16.0 & 4.2 & 100.0 & 100.0 \\
\hline Salsola kali* (Russian thistle) & 3.5 & 3.8 & 73.3 & 86.7 \\
\hline Ambrosia acanthicarpa (bur ragweed) & 1.2 & -- & 13.3 & -- \\
\hline Sisymbrium altissimum* (tumble mustard) & 0.5 & 0.2 & 20.0 & 6.7 \\
\hline Chenopodium leptophyllum (slimeleaf goosefoot) & 0.3 & -- & 13.3 & -- \\
\hline Triticum aestivum* (common wheat) & 0.3 & -- & 13.3 & -- \\
\hline Plantago patagonica (Indian wheat) & 0.3 & -- & 13.3 & -- \\
\hline Amsinckia lycopsoides (tarweed fiddleneck) & 0.2 & 0.2 & 6.7 & 6.7 \\
\hline Holosteum umbellatum* (jagged chickweed) & 0.2 & -- & 6.7 & -- \\
\hline Draba verna* (spring whitlow) & 0.2 & -- & 6.7 & -- \\
\hline Astragalus spp. & 0.2 & -- & 6.7 & -- \\
\hline Microsteris gracilis (annual phlox) & 0.2 & -- & 6.7 & -- \\
\hline Achillea millefolium (yarrow) & 0.2 & $\mathrm{X}$ & 6.7 & $\mathrm{X}$ \\
\hline Grayia spinosa (hopsage) & $\mathrm{X}$ & $\mathrm{X}$ & $\mathrm{X}$ & $\mathrm{X}$ \\
\hline Machaeranthera canescens (hoary aster) & $\mathrm{X}$ & -- & $\mathrm{X}$ & -- \\
\hline Hackelia diffusa (sagebrush stickseed) & $\mathrm{X}$ & -- & $\mathrm{X}$ & -- \\
\hline Chondrilla juncea* (rush skeletonweed) & $\mathrm{X}$ & -- & $\mathrm{X}$ & -- \\
\hline Artemesia tridentata (sagebrush) & $\mathrm{X}$ & 0.3 & $\mathrm{X}$ & 13.3 \\
\hline Chenopodium album (lambsquarters) & $\mathrm{X}$ & -- & $\mathrm{X}$ & -- \\
\hline Lactuca seriola* (prickly lettuce) & $\mathrm{X}$ & $\mathrm{X}$ & $\mathrm{X}$ & $\mathrm{X}$ \\
\hline Hordeum leporinum* (hare barley) & $\mathrm{X}$ & -- & $\mathrm{X}$ & -- \\
\hline Chrysothamnus nauseosus (gray rabbitbrush) & -- & 0.3 & -- & 13.3 \\
\hline Poa bulbosa* (bulbous bluegrass) & -- & $\mathrm{X}$ & -- & $\mathrm{X}$ \\
\hline Agoseris heterophylla (mountain-dandelion) & -- & $\mathrm{X}$ & -- & $\mathrm{X}$ \\
\hline Machaeranthera canescens (hoary aster) & -- & $\mathrm{X}$ & -- & $\mathrm{X}$ \\
\hline Triticum aestivum* (common wheat) & -- & $\mathrm{X}$ & -- & $\mathrm{X}$ \\
\hline Biotic crust & 0.0 & 0.0 & 0.0 & 0.0 \\
\hline Bare Soil & 46.3 & 37.2 & 100.0 & 100.0 \\
\hline Litter & 45.2 & 50.7 & 100.0 & 100.0 \\
\hline Total Canopy Cover (litter not included) & 72.3 & 22.5 & & \\
\hline $\begin{array}{l}\text { * Introduced species. } \\
\mathrm{X} \text { = Species present but not counted in a plot frame } \\
\text {-- species not observed on site }\end{array}$ & & & & \\
\hline \multicolumn{5}{|l|}{$\begin{array}{l}\text { bIncludes Sandberg's bluegrass, bluebunch } \\
\text { wheatgrass, thickspike wheatgrass, Indian ricegrass, } \\
\text { needle-and-thread grass, and prairie junegrass } \\
\text { seedlings. }\end{array}$} \\
\hline Total Introduced \% Cover 2008 & 53.8 & 17.5 & & \\
\hline Total Native \% Cover 2008 & 18.5 & 5.0 & & \\
\hline
\end{tabular}


Table B-14. Percent Canopy Cover and Frequency of Occurrence at 100-B-1 and 128-C-1 in 2008.

\begin{tabular}{|c|c|c|c|c|}
\hline Species & $\begin{array}{l}\text { \% Cover } \\
100-B-1 \\
\end{array}$ & $\begin{array}{l}\text { \% Cover } \\
128-\mathrm{C}-1 \\
\end{array}$ & $\begin{array}{c}\text { Freq of Occ } \\
\% \\
\end{array}$ & $\begin{array}{c}\text { Freq of Occ } \\
\%\end{array}$ \\
\hline Poa sandbergii (Sandberg's bluegrass) & 43.9 & 15.3 & 100.0 & 100.0 \\
\hline Bromus tectorum* (cheatgrass) & 23.6 & 24.8 & 100.0 & 100.0 \\
\hline Salsola kali* (Russian thistle) & 5.9 & 5.2 & 100.0 & 80.0 \\
\hline Agropyron spicatum (bluebunch wheatgrass) & 2.5 & 2.7 & 40.0 & 40.0 \\
\hline Sisymbrium altissimum* (tumble mustard) & 1.7 & 0.7 & 28.0 & 26.7 \\
\hline Artemesia tridentata (sagebrush) & 0.1 & 5.7 & 4.0 & 6.7 \\
\hline Oryzopsis hymenoides (Indian ricegrass) & 0.6 & 1.2 & 4.0 & 13.3 \\
\hline Sitanion hystrix & -- & 14.7 & -- & 73.3 \\
\hline Microsteris gracilis (annual phlox) & 0.1 & -- & 4.0 & -- \\
\hline Lomatium macrocarpum (bigseed desertparsley) & 0.1 & -- & 4.0 & -- \\
\hline Sitanion hystrix (bottlebrush squirreltail) & $\mathrm{X}$ & -- & $\mathrm{X}$ & -- \\
\hline Grayia spinosa (hopsage) & $\mathrm{X}$ & -- & $\mathrm{X}$ & -- \\
\hline Tragopogon dubius (yellow salsify) & $\mathrm{X}$ & -- & $\mathrm{X}$ & -- \\
\hline Sphaeralcea munroana (Munro's globemallow) & $\mathrm{X}$ & -- & $\mathrm{X}$ & -- \\
\hline Koeleria cristata (prairie junegrass) & $\mathrm{X}$ & -- & $\mathrm{X}$ & -- \\
\hline Hordeum leporinum * (hare barley) & $\mathrm{X}$ & -- & $\mathrm{X}$ & -- \\
\hline Amsinckia lycopsoides (tarweed fiddleneck) & $\mathrm{X}$ & -- & $\mathrm{X}$ & -- \\
\hline Descurainia pinnata (western tansymustard) & $\mathrm{X}$ & -- & $\mathrm{X}$ & -- \\
\hline Astragalus purshii (wolly-pod milkvetch) & $\mathrm{X}$ & -- & $\mathrm{X}$ & -- \\
\hline Machaeranthera canescens (hoary aster) & $\mathrm{X}$ & -- & $\mathrm{X}$ & -- \\
\hline Lactuca seriola* (prickly lettuce) & -- & 0.5 & -- & 20.0 \\
\hline Chrysothamnus nauseosus (gray rabbitbrush) & -- & 0.2 & -- & 6.7 \\
\hline Draba verna* (spring whitlowgrass) & -- & 1.3 & -- & 20.0 \\
\hline Erodium cicutarium* (storksbill) & -- & $\mathrm{X}$ & -- & $\mathrm{X}$ \\
\hline Tragopogon dubius* (yellow salsify) & -- & $\mathrm{X}$ & -- & $\mathrm{X}$ \\
\hline Biotic crust & 29.2 & 0.0 & 96.0 & 0.0 \\
\hline Bare Soil & 49.5 & 37.5 & 100.0 & 100.0 \\
\hline Litter & 43.2 & 57.8 & 100.0 & 100.0 \\
\hline Total canopy cover (litter not included) & 34.6 & 56.8 & & \\
\hline \multicolumn{5}{|l|}{ * Invasive species } \\
\hline \multicolumn{5}{|l|}{$\begin{array}{l}X=\text { present but not counted in plot frames } \\
\text {-- species not present on site }\end{array}$} \\
\hline Total Invasive \% Cover & 31.2 & 32.5 & & \\
\hline Total Native \% Cover & 47.3 & 39.7 & & \\
\hline Total Change in Native Cover from 2007 & +1.9 & +14.7 & & \\
\hline
\end{tabular}


WCH-428

Rev. 0

Table B-15. Percent Canopy Cover at 100-C-9 in 2008.

\begin{tabular}{|c|c|c|c|}
\hline Species & T1 & T2 & T3 \\
\hline Poa sandbergii (Sandberg's bluegrass) & 12.0 & 5.0 & 17.0 \\
\hline Agropyron spicatum (bluebunch wheatgrass) & 9.5 & 1.3 & 9.2 \\
\hline Bromus tectorum* (cheatgrass) & 4.8 & 11.3 & 33.0 \\
\hline Salsola kali* (Russian thistle) & 2.5 & 2.3 & 4.2 \\
\hline Draba verna* (spring whitlowgrass) & 0.3 & 0.2 & 0.5 \\
\hline Festuca octoflora (slender sixweeks) & 0.3 & 1.0 & -- \\
\hline Sisymbrium altissimum* (tumble mustard) & 0.5 & 1.8 & 11.5 \\
\hline Descurainia pinnata (western tansymustard) & 0.3 & 0.7 & 0.5 \\
\hline Oryzopsis hymenoides (Indian ricegrass) & 1.5 & -- & 0.2 \\
\hline Artemesia tridentata (sagebrush) & 0.2 & $\mathrm{X}$ & 0.2 \\
\hline Lactuca seriola* (prickly lettuce) & 0.2 & & 0.2 \\
\hline Holosteum umbellatum* (jagged chickweed) & $\mathrm{X}$ & 0.2 & 2.8 \\
\hline Poa bulbosa* (bulbous bluegrass) & $\mathrm{X}$ & 0.3 & -- \\
\hline Chrysothamnus nauseosus (gray rabbitbrush) & $\mathrm{X}$ & -- & -- \\
\hline Machaeranthera canescens (hoary aster) & $\mathrm{X}$ & -- & -- \\
\hline Erodium cicutarium* (storksbill) & -- & 0.2 & 0.2 \\
\hline Amsinckia lycopsoides (tarweed fiddleneck) & -- & -- & 0.2 \\
\hline Centaurea diffusa* (diffuse knapweed) & -- & $\mathrm{X}$ & 0.5 \\
\hline Verbena bracteata* (big-bract verbena) & -- & & $\mathrm{X}$ \\
\hline Erigonum vimineum (broom buckwheat) & -- & 0.7 & -- \\
\hline Sitanion hystrix (bottlebrush squirreltail) & -- & 0.2 & -- \\
\hline Sphaeralcea munroana (Munro's globemallow) & -- & $\mathrm{X}$ & -- \\
\hline Chaenactis douglasii (hoary falseyarrow) & -- & $\mathrm{X}$ & -- \\
\hline Chorispora tenella ${ }^{\text {a }}$ (blue mustard) & -- & $\mathrm{X}$ & -- \\
\hline Biotic crust & 0.0 & 0.0 & 0.0 \\
\hline Bare Soil & 54.8 & 42.0 & 34.2 \\
\hline Litter & 43.5 & 57.8 & 64.2 \\
\hline Total canopy cover (litter not included) & 32.2 & 25.2 & 80.0 \\
\hline \multicolumn{4}{|l|}{$*=$ Invasive species } \\
\hline \multirow{2}{*}{\multicolumn{4}{|c|}{$\begin{array}{l}X=\text { present but not counted in plot frames } \\
--=\text { not present in plot }\end{array}$}} \\
\hline & & & \\
\hline Total Invasive \% Cover & 8.3 & 16.3 & 52.8 \\
\hline Total Native \% Cover & 23.8 & 8.8 & 27.2 \\
\hline Change in Native Cover \% from 2007 & -30.8 & -9.7 & -15.5 \\
\hline
\end{tabular}


Table B-16. Frequency of Occurrence at 100-C-9 in 2008.

\begin{tabular}{|c|c|c|c|}
\hline Species & T1 & $\mathbf{T 2}$ & T3 \\
\hline Salsola kali* (Russian thistle) & 100.0 & 93.3 & 100.0 \\
\hline Poa sandbergii (Sandberg's bluegrass) & 100.0 & 100.0 & 100.0 \\
\hline Agropyron spicatum (bluebunch wheatgrass) & 60.0 & 53.3 & 73.3 \\
\hline Bromus tectorum* (cheatgrass) & 66.7 & 100.0 & 86.7 \\
\hline Sisymbrium altissimum* (tumble mustard) & 20.0 & 73.3 & 100.0 \\
\hline Descurainia pinnata (western tansymustard) & 13.3 & 26.7 & 20.0 \\
\hline Draba verna* (spring whitlowgrass) & 13.3 & 6.7 & 20.0 \\
\hline Festuca octoflora (slender sixweeks) & 13.3 & 40.0 & -- \\
\hline Oryzopsis hymenoides (Indian ricegrass) & 26.7 & -- & 6.7 \\
\hline Artemesia tridentata (sagebrush) & 6.7 & $\mathrm{X}$ & 6.7 \\
\hline Lactuca seriola* (prickly lettuce) & 6.7 & -- & 6.7 \\
\hline Holosteum umbellatum* (jagged chickweed) & $\mathrm{X}$ & 6.7 & 20.0 \\
\hline Poa bulbosa* (bulbous bluegrass) & $\mathrm{X}$ & 13.3 & -- \\
\hline Chrysothamnus nauseosus (gray rabbitbrush) & $\mathrm{X}$ & -- & -- \\
\hline Machaeranthera canescens (hoary aster) & $\mathrm{X}$ & -- & -- \\
\hline Erodium cicutarium* (storksbill) & -- & 6.7 & 6.7 \\
\hline Amsinckia lycopsoides (tarweed fiddleneck) & -- & -- & 6.7 \\
\hline Centaurea diffusa* (diffuse knapweed) & -- & $\mathrm{X}$ & 20.0 \\
\hline Verbena bracteata (big-bract verbena) & -- & & $\mathrm{X}$ \\
\hline Erigonum vimineum (broom buckwheat) & -- & 26.7 & - \\
\hline Sitanion hystrix (bottlebrush squirreltail) & -- & 6.7 & -- \\
\hline Sphaeralcea munroana (Munro's globemallow) & -- & $\mathrm{X}$ & -- \\
\hline Chaenactis douglasii (hoary falseyarrow) & -- & $\mathrm{X}$ & -- \\
\hline Chorispora tenella ${ }^{\text {a }}$ (blue mustard) & -- & $\mathrm{X}$ & -- \\
\hline Biotic crust & 0.0 & 0.0 & 0.0 \\
\hline Bare Soil & 100.0 & 100.0 & 100.0 \\
\hline Litter & 100.0 & 100.0 & 100.0 \\
\hline
\end{tabular}


Table B-17. Percent Canopy Cover and Frequency of Occurrence at 100-B-14 South in 2008.

\begin{tabular}{|c|c|c|}
\hline Species & \% Cover & Freq. of Occ. \\
\hline Salsola kali* (Russian thistle) & 31.4 & 100 \\
\hline Sisymbrium altissimum* (tumble mustard) & 7.3 & 76 \\
\hline Native Grasses ${ }^{\mathrm{b}}$ & 6.7 & 76 \\
\hline Artemesia tridentata (sagebrush) & 0.1 & 4 \\
\hline Bromus tectorum* (cheatgrass) & 1.1 & 24 \\
\hline Chrysothamnus nauseosus (gray rabbitbrush) & 0.9 & 16 \\
\hline Melilotus alba* (sweetclover) & 0.6 & 4 \\
\hline Chorispora tenella* (blue mustard) & 0.1 & 4 \\
\hline Festuca octoflora (slender sixweeks) & 0.1 & 4 \\
\hline Poa bulbosa* (Bulbous bluegrass) & $\mathrm{X}$ & $\mathrm{X}$ \\
\hline Epilobium paniculatum (tall willowherb) & $\mathrm{X}$ & $\mathrm{X}$ \\
\hline Lactuca serriola * (prickly lettuce) & $\mathrm{X}$ & $\mathrm{X}$ \\
\hline Centaurea diffusa * (diffuse knapweed) & $\mathrm{X}$ & $\mathrm{X}$ \\
\hline Ranunculus testiculatus* (bur buttercup) & $\mathrm{X}$ & $\mathrm{X}$ \\
\hline Biotic Crust & 0 & 0 \\
\hline Bare Soil & 50.8 & 96 \\
\hline Litter & 46.8 & 88 \\
\hline
\end{tabular}

Total canopy cover (litter not included)

48.3

* Invasive species

$\mathrm{X}=$ present but not counted in plot frames

bIncludes Sandberg's bluegrass, bluebunch wheatgrass, thickspike wheatgrass, Indian ricegrass, needle-andthread grass, and prairie junegrass seedlings.

Total Invasive \% Cover

Total Native \% Cover 
Table B-18. Percent Canopy Cover and Frequency of Occurrence at the 118-B-1 Burial Ground and Soil Staging Area 2008.

\begin{tabular}{|c|c|c|c|c|}
\hline Species & $\begin{array}{c}\text { \% Cover } \\
\text { SSA } \\
\end{array}$ & $\begin{array}{c}\begin{array}{c}\text { \% Cover } \\
\text { BG }\end{array} \\
\end{array}$ & $\begin{array}{c}\text { Freq of Occ } \\
\% \text { SSA } \\
\end{array}$ & $\begin{array}{c}\text { Freq of Occ } \\
\% \text { BG } \\
\end{array}$ \\
\hline Native Grasses $^{\mathrm{b}}$ & 11.0 & 13.6 & 76.0 & 84.0 \\
\hline Salsola kali* (Russian thistle) & 4.5 & 3.8 & 64.0 & 72.0 \\
\hline Bromus tectorum* (cheatgrass) & 1.2 & 2.0 & 28.0 & 24.0 \\
\hline Lactuca seriola* (prickly lettuce) & 0.1 & -- & 4.0 & -- \\
\hline Sisymbrium altissimum* (tumble mustard) & 0.3 & 0.6 & 12.0 & 24.0 \\
\hline Poa bulbosa* (Bulbous bluegrass) & 0.2 & $\mathrm{X}$ & 8.0 & $\mathrm{X}$ \\
\hline Chrysothamnus nauseosus (gray rabbitbrush) & 0.1 & 0.4 & 4.0 & 16.0 \\
\hline Festuca octoflora (slender sixweeks) & 0.1 & 0.6 & 4.0 & 4.0 \\
\hline Ambrosia acanthicarpa (bur ragweed) & 0.1 & -- & 4.0 & -- \\
\hline Melilotus alba * (sweetclover) & 0.1 & $\mathrm{X}$ & 4.0 & $\mathrm{X}$ \\
\hline Microsteris gracilis (pink microsteris) & $\mathrm{X}$ & -- & $\mathrm{X}$ & -- \\
\hline Chenopodium leptophyllum (slimleaf goosefoot) & $\mathrm{X}$ & $\mathrm{X}$ & $\mathrm{X}$ & $\mathrm{X}$ \\
\hline Erodium cicutarium* (storksbill) & $\mathrm{X}$ & 0.2 & $\mathrm{X}$ & 8.0 \\
\hline Lactuca serriola* (prickly lettuce) & $\mathrm{X}$ & 0.1 & $\mathrm{X}$ & 4.0 \\
\hline Artemesia tridentata (sagebrush) & $\mathrm{X}$ & 0.3 & $\mathrm{X}$ & 12.0 \\
\hline Amsinckia lycopsoides (fiddleneck) & $\mathrm{X}$ & $\mathrm{X}$ & $\mathrm{X}$ & $\mathrm{X}$ \\
\hline Achillea millefolium (yarrow) & $\mathrm{X}$ & -- & $\mathrm{X}$ & -- \\
\hline Centaurea diffusa $*$ (diffuse knapweed) & -- & 0.2 & -- & 8.0 \\
\hline Descurainia pinnata (western tansymustard) & -- & $\mathrm{X}$ & -- & $\mathrm{X}$ \\
\hline Chorispora tenella* (blue mustard) & -- & $\mathrm{X}$ & -- & $\mathrm{X}$ \\
\hline Hordeum leporinum * (hare barley) & -- & $\mathrm{X}$ & -- & $\mathrm{X}$ \\
\hline Biotic crust & 0.0 & 0.0 & 0.0 & 0.0 \\
\hline Bare soil & 48.8 & 38.7 & 92.0 & 92.0 \\
\hline Litter & 50.0 & 58.6 & 100.0 & 100.0 \\
\hline Total canopy cover (litter not included) & 17.7 & 21.8 & & \\
\hline \multicolumn{5}{|l|}{ * Invasive species } \\
\hline \multicolumn{5}{|l|}{$\mathrm{X}=$ present but not counted in plot frames } \\
\hline \multicolumn{5}{|l|}{$\begin{array}{l}\text { bIncludes Sandberg's bluegrass, bluebunch } \\
\text { wheatgrass, thickspike wheatgrass, Indian } \\
\text { ricegrass, needle-and-thread grass, and prairie } \\
\text { junegrass seedlings. }\end{array}$} \\
\hline Total Invasive \% Cover & 6.4 & 6.9 & & \\
\hline Total Native \% Cover & 11.3 & 14.9 & & \\
\hline
\end{tabular}


Table B-19. Percent Canopy Cover and Frequency of Occurrence at 118-C-1 in 2008.

\begin{tabular}{|c|c|c|}
\hline Species & \% Cover & Freq of Occ \% \\
\hline Salsola kali* (Russian thistle) & 21.2 & 100 \\
\hline NATIVE GRASSES ${ }^{\mathrm{b}}$ & 9.7 & 100 \\
\hline Sisymbrium altissimum* (tumble mustard) & 1.6 & 44 \\
\hline Bromus tectorum* (cheatgrass) & 0.6 & 24 \\
\hline Chrysothamnus nauseosus (gray rabbitbrush) & 0.2 & 8 \\
\hline Lactuca seriola* (prickly lettuce) & 0.2 & 8 \\
\hline Amsinckia lycopsoides (tarweed fiddleneck) & $\mathrm{X}$ & X \\
\hline Kochia scopari* (kochia) & $\mathrm{X}$ & $\mathrm{X}$ \\
\hline Melilotus alba * (sweetclover) & $\mathrm{X}$ & $\mathrm{X}$ \\
\hline Sisymbrium altissimum* (tumble mustard) & $\mathrm{X}$ & $\mathrm{X}$ \\
\hline Biotic crust & 0 & 0 \\
\hline Bare soil & 33.2 & 92 \\
\hline Litter & 62.6 & 100 \\
\hline
\end{tabular}

Total canopy cover (litter not included) 33.5

* Invasive species

$\mathrm{X}=$ present but not counted in plot frames

bIncludes Sandberg's bluegrass, bluebunch wheatgrass, thickspike wheatgrass, Indian ricegrass, needle-and-thread grass, and prairie junegrass seedlings.

Total Invasive \% Cover 23.6

Total Native \% Cover 
Table B-20. Percent Canopy Cover at the Horseshoe Landfill and Soil Staging Area in 2008.

\begin{tabular}{|c|c|c|}
\hline Species & $\underline{\text { HSLF }}$ & $\underline{\text { SSA }}$ \\
\hline Poa sandbergii (Sandberg's bluegrass) & 60.0 & 46.0 \\
\hline Agropyron spicatum (bluebunch wheatgrass) & 7.2 & 3.7 \\
\hline Bromus tectorum* (cheatgrass) & 2.5 & 13.5 \\
\hline Salsola kali* (Russian thistle) & 0.8 & 17.0 \\
\hline Artemesia tridentata (sagebrush) & 2.2 & 4.8 \\
\hline Sitanion hystrix (bottlebrush squireltail) & 3.7 & 1.3 \\
\hline Lupinus leucophyllus (velvet lupine) & 1.0 & 0.7 \\
\hline Epilobium paniculatum (tall willowherb) & 0.8 & 0.2 \\
\hline Agropyron cristatum* (crested wheatgrass) & 0.2 & 0.2 \\
\hline Lactuca seriola* (prickly lettuce) & 0.3 & 0.2 \\
\hline Crepis atrabarba (slender hawksbeard) & -- & 3.7 \\
\hline Sisymbrium altissimum* (tumble mustard) & $\mathrm{X}$ & 2.3 \\
\hline Oryzopsis hymenoides (Indian ricegrass) & 1.7 & $\mathrm{X}$ \\
\hline Amsinckia lycopsoides (tarweed fiddleneck) & -- & 1.5 \\
\hline Festuca octoflora (slender sixweeks) & -- & 0.3 \\
\hline Kochia scoparia* (kochia) & -- & 0.3 \\
\hline Machaeranthera canescens (hoary aster) & 0.3 & $\mathrm{X}$ \\
\hline Draba verna* (spring whitlowgrass) & -- & 0.2 \\
\hline Descurainia pinnata (western tansymustard) & -- & 0.2 \\
\hline Chrysothamnus nauseosus (gray rabbitbrush) & 0.2 & -- \\
\hline Lomatium macrocarpum(bigseed desertparsley) & -- & $\mathrm{X}$ \\
\hline Phlox longifolia (longleaf phlox) & -- & $\mathrm{X}$ \\
\hline Erodium cicutarium* (storksbill) & -- & $\mathrm{X}$ \\
\hline Achillea millefolium (yarrow) & -- & $\mathrm{X}$ \\
\hline Tragopogon dubius* (yellow salsify) & -- & $\mathrm{X}$ \\
\hline Biotic crust & 43.3 & 42.0 \\
\hline Bare Soil & 52.2 & 42.0 \\
\hline Litter & 45.2 & 45.3 \\
\hline Total Canopy Cover (excludes litter) & 80.8 & 96.0 \\
\hline \multicolumn{3}{|l|}{ * Invasive species } \\
\hline \multicolumn{3}{|l|}{$\begin{array}{l}X=\text { present but not counted in plot frames } \\
\text {-- species not recorded }\end{array}$} \\
\hline Total Invasive \% Cover & 3.8 & 33.7 \\
\hline Total Native \% Cover & 77.0 & 62.3 \\
\hline Change in Native Cover from 2007 & $\wedge 41.7$ & $\wedge 27.0$ \\
\hline
\end{tabular}




\section{Table B-21. Frequency of Occurrence at the Horseshoe Landfill and Soil Staging} Area in 2008.

$\underline{\text { Species }}$

HSLF

Sisymbrium altissimum* (tumble mustard)

Bromus tectorum* (cheatgrass)

Poa sandbergii (Sandberg's bluegrass)

Agropyron spicatum (bluebunch wheatgrass)

Sitanion hystrix (bottlebrush squireltail)

Salsola kali* (Russian thistle)

Lupinus leucophyllus (velvet lupine)

Festuca octoflora (slender sixweeks)

Kochia scoparia* (kochia)

Artemesia tridentata (sagebrush)

Lactuca seriola* (prickly lettuce)

Amsinckia lycopsoides (tarweed fiddleneck)

Draba verna* (spring whitlowgrass)

Crepis atrabarba (slender hawksbeard)

Descurainia pinnata (western tansymustard)

Epilobium paniculatum (tall willowherb)

Agropyron cristatum* (crested wheatgrass)

Oryzopsis hymenoides (Indian ricegrass)

Lomatium macrocarpum(bigseed desertparsley)

Phlox longifolia (longleaf phlox)

Erodium cicutarium* (storksbill)

Machaeranthera canescens (hoary aster)

Achillea millefolium (yarrow)

Tragopogon dubius* (yellow salsify)

Chrysothamnus nauseosus (gray rabbitbrush)

Biotic crust

Bare Soil

Litter

* Invasive species

$\mathrm{X}=$ present but not counted in plot frames

-- species not recorded

\section{$\mathrm{X}$}

100.0

$\underline{\text { SSA }}$

93.3

100.0

93.3

60.0

100.0

46.7

20.0

33.3

20.0

$\begin{array}{ll}-- & 26.7\end{array}$

13.3

$\begin{array}{ll}-- & 13.3\end{array}$

$20.0 \quad 33.3$

$13.3 \quad 6.7$

$\begin{array}{ll}- & 26.7\end{array}$

$\begin{array}{ll}-- & 6.7\end{array}$

$\begin{array}{ll}-- & 20.0\end{array}$

$\begin{array}{ll}-- & 6.7\end{array}$

$\begin{array}{ll}33.3 & 6.7\end{array}$

$\begin{array}{ll}6.7 & 6.7\end{array}$

$33.3 \quad \mathrm{X}$

-- X

$\begin{array}{ll}- & \mathrm{X} \\ -- & \end{array}$

-- $\quad$ X

$13.3 \quad \mathrm{X}$

$\begin{array}{ll}-- & X \\ - & \end{array}$

-- $\quad \mathrm{X}$

$6.7--$

$100.0 \quad 100.0$

$100.0 \quad 100.0$

$100.0 \quad 100.0$ 
WCH-428

Rev. 0

2010 River Corridor Closure Contractor Revegetation and Mitigation Monitoring Report 
WCH-428

Rev. 0

\section{APPENDIX C}

\section{REVEGETATION MONITORING RESULTS}


WCH-428

Rev. 0

2010 River Corridor Closure Contractor Revegetation and Mitigation Monitoring Report September 2010 
Table C-1. Percent Canopy Cover and Frequency of Occurrence at the 300-FF-1 Process Ponds and Burial Grounds in 2007.

\begin{tabular}{|c|c|c|}
\hline Species & $\%$ Cover & \% Frequency \\
\hline Poa sandbergii (Sandberg's bluegrass) & 7.9 & 57 \\
\hline Bromus tectorum* (cheatgrass) & 32.0 & 97 \\
\hline Salsola kali* (Russian thistle) & 3.4 & 80 \\
\hline Ag. Spp.(Wheatgrasses) & 20.4 & 74 \\
\hline Oryzopsis hymenoides (Indian ricegrass) & 0.1 & 3 \\
\hline Vulpia myuros* (rattail fescue) & 3.7 & 51 \\
\hline Lactuca serriola* (prickly lettuce) & 0.9 & 37 \\
\hline Centaurea diffusa* (diffuse knapweed) & 0.8 & 17 \\
\hline Festuca octoflora (six-weeks fescue) & 0.4 & 17 \\
\hline Erodium cicutarium*(storksbill) & 5.3 & 51 \\
\hline Sisymbrium altissimum* (tumble mustard) & 0.8 & 31 \\
\hline Epilobium paniculatum (tall willowherb) & 0.2 & 9 \\
\hline Agropyron cristatum* (Crested Wheatgrass) & 3.1 & 40 \\
\hline Senecio vulgaris (common groundsel) & 0.1 & 6 \\
\hline Amsinckia lycopsoides (tarweed fiddleneck) & 0.3 & 11 \\
\hline Lepidium perfoliatum (clasping pepperweed) & 4.7 & 11 \\
\hline Descurainia pinnata (western tansymustard) & 0.1 & 6 \\
\hline Tragopogon dubius* (yellow salsify) & 0.1 & 3 \\
\hline Hordeum leporinum(hare barley) & 0.1 & 3 \\
\hline Holosteum umbellatum (jagged chickweed) & 0.0 & 0 \\
\hline Petalostemon ornatum (prairie clover) & $\mathrm{X}$ & $\mathrm{X}$ \\
\hline Melilotus alba * (sweetclover) & $\mathrm{X}$ & $\mathrm{X}$ \\
\hline Chrysothamnus nauseosus (gray rabbitbrush) & $\mathrm{X}$ & $\mathrm{X}$ \\
\hline Artemisia tridentata (sagebrush) & $\mathrm{X}$ & $\mathrm{X}$ \\
\hline Tragopogon dubius (yellow salsify) & $\mathrm{X}$ & $\mathrm{X}$ \\
\hline Achillea millefolium (yarrow) & $\mathrm{X}$ & $\mathrm{X}$ \\
\hline Cardaria draba * (whitetop) & $\mathrm{X}$ & $\mathrm{X}$ \\
\hline Machaeranthera canescens (hoary aster) & $\mathrm{X}$ & $\mathrm{X}$ \\
\hline Descurainia pinnata (western tansymustard) & $X$ & $\mathrm{X}$ \\
\hline Agoseris heterophylla (mountain dandelion) & $\mathrm{X}$ & $\mathrm{X}$ \\
\hline Malva neglecta* (cheeseweed) & $\mathrm{X}$ & $\mathrm{X}$ \\
\hline Centaurea repens * (Russian knapweed) & $\mathrm{X}$ & $\mathrm{X}$ \\
\hline Biotic crust & 7.2 & 31 \\
\hline Bare Soil & 34.5 & 100 \\
\hline Litter & 62.0 & 100 \\
\hline Total canopy cover (Biotic crust and litter not included) & 84.4 & \\
\hline
\end{tabular}

*Introduced species.

$\mathrm{X}=$ Species present on the site but not counted in a plot frame.

Total Introduced species \% Cover $2007 \quad 50.0$

Total Native \% Cover $2007 \quad 34.4$

Change in Native Plant \% Cover from 2006 to $2007 \quad+15.7$ 
Table C-2. Percent Canopy Cover and Frequency of Occurrence at 618-2 \& 618-3 in 2007.

\begin{tabular}{lcc}
\hline \multicolumn{1}{c}{ Species } & \% Cover & \% Freq \\
\hline Salsola kali* (Russian thistle) & 11.8 & 100 \\
Sisymbrium altissimum* (tumble mustard) & 7.6 & 88 \\
Bromus tectorum* (cheatgrass) & 4.6 & 84 \\
Agropyron spp. (wheatgrasses) & 11.2 & 100 \\
Ambrosia acanthicarpa (bur ragweed) & 0.3 & 12 \\
Amsinckia lycopsoides (tarweed fiddleneck) & 0.1 & 4 \\
Epilobium paniculatum (tall willowherb) & 0.1 & 4 \\
Erodium cicutarium* (storksbill) & 0.1 & 4 \\
Bare Soil & 58.9 & 100 \\
Litter & 35.5 & 96 \\
Total canopy cover (Litter not included) & $\mathbf{3 5 . 8}$ & \\
\hline
\end{tabular}

* Intoduced Species

$\mathrm{X}=$ present but not counted in plot frames

Total Introduced Species \% Cover 2007

24.1

Total Native \% Cover 2007

11.7

Table C-3. Percent Canopy Cover and Frequency of Occurrence at 300-8 in 2007.

\begin{tabular}{lcc}
\hline \multicolumn{1}{c}{ Species } & \% Cover & \% Freq \\
\hline Salsola kali* (Russian thistle) & 12.6 & 100 \\
Sisymbrium altissimum* (tumble mustard) & 12.6 & 96 \\
Bromus tectorum* (cheatgrass) & 16.2 & 88 \\
Ambrosia acanthicarpa (bur ragweed) & 0.3 & 12 \\
Agropyron spp. (wheatgrasses) & 36.2 & 100 \\
Holosteum umbellatum* (jagged chickweed) & 0.2 & 8 \\
Machaeranthera canescens (hoary aster) & 0.3 & 12 \\
Plantago patagonica (Indian wheat) & 0.1 & 4 \\
Vulpia myuros (rattail fescue) & 1.2 & 8 \\
Draba verna* (spring whitlowgrass) & 0.4 & 16 \\
Artemisia tridentata (sagebrush) & 0.3 & 12 \\
Oenothera pallida (primerose) & 1.5 & 4 \\
Erodium cicutarium* (storksbill) & 0.1 & 4 \\
Chrysothamnus nauseosus (gray rabbitbrush) & $\mathrm{X}$ & $\mathrm{X}$ \\
Lactuca serriola * (prickly lettuce) & $\mathrm{X}$ & $\mathrm{X}$ \\
Conyza canadensis * (horseweed) & $\mathrm{X}$ & $\mathrm{X}$ \\
Amsinckia lycopsoides (tarweed fiddleneck) & $\mathrm{X}$ & $\mathrm{X}$ \\
Centaurea diffusa $*$ (diffuse knapweed) & $\mathrm{X}$ & $\mathrm{X}$ \\
Bare Soil & 54.2 & 100 \\
Litter & 45.9 & 100 \\
Total canopy cover (Litter not included) & $\mathbf{8 2 . 0}$ & \\
\hline
\end{tabular}

* Introduced Species

$\mathrm{X}=$ present but not counted in plot frames

Total Introduced Species \% Cover 2007

41.9

Total Native \% Cover 2007

40.1 
Table C-4. Percent Canopy Cover on the 120-N-1 and 120-N-2 Sites in 2007.

\begin{tabular}{lcccc}
\hline \multicolumn{1}{c}{ Species } & $\begin{array}{c}\text { Biosol and } \\
\text { Straw } \\
\text { Mulch }\end{array}$ & $\begin{array}{c}\text { Biosol and } \\
\text { Hydromulch }\end{array}$ & $\begin{array}{c}\text { Triple-16 } \\
\text { and Straw } \\
\text { Mulch }\end{array}$ & $\begin{array}{c}\text { Triple-16 and } \\
\text { Hydromulch }\end{array}$ \\
\hline Bromus tectorum* (cheatgrass) & 83.7 & 71.3 & 34.3 & 16.2 \\
Poa sandbergii (Sandberg's bluegrass) & 11.7 & 1.2 & 29.3 & 23.2 \\
Agropyron spicatum (bluebunch wheatgrass) & 5.2 & 2.7 & 33.7 & 3.3 \\
Agropyron dasytachyum (thickspike wheatgrass) & -- & -- & 0.2 & -- \\
Centaurea diffusa* (diffuse knapweed) & 0.2 & 0.3 & 0.8 & 1.5 \\
Poa bulbosa* (bulbous bluegrass) & -- & 1.0 & 0.3 & -- \\
Artemisia tridentata (sagebrush) & -- & 0.0 & 0.2 & -- \\
Salsola kali* (Russian thistle) & 1.5 & 1.3 & 0.2 & 3.0 \\
Achillea millefolium (yarrow) & 0.2 & -- & 0.3 & 6.2 \\
Holosteum umbellatum* (jagged chickweed) & -- & 0.2 & 0.2 & 0.7 \\
Erysimum asperum (wallflower) & -- & 0.0 & -- & 0.0 \\
Chrysothamnus nauseosus (gray rabbitbrush) & -- & 0.2 & -- & 4.5 \\
Oryzopsis hymenoides (Indian ricegrass) & -- & 2.0 & -- & 2.0 \\
Sisymbrium altissimum* (tumble mustard) & 0.2 & 1.0 & $\mathrm{X}$ & 0.2 \\
Tragopogon dubius* (yellow salsify) & -- & -- & -- & 0.2 \\
Erigeron poliospermus (cushion fleabane) & -- & -- & $\mathrm{X}$ & 1.0 \\
Draba verna* (spring whitlow) & -- & 0.2 & -- & -- \\
Lactuca serriola* (prickly lettuce) & -- & -- & $\mathrm{X}$ & 0.2 \\
Penstemon acuminatus (sand beardtongue) & -- & -- & -- & $\mathrm{X}$ \\
Chaenactis douglasii (hoary falseyarrow) & -- & -- & -- & $\mathrm{X}$ \\
Erysimum asperum (rough wallflower) & -- & -- & $\mathrm{X}$ & - \\
Hordeum leporinum* (hare barley) & -- & -- & $\mathrm{X}$ & - \\
Biotic crust & -- & -- & 3.00 & 2.33 \\
Bare soil & 23.83 & 39.17 & 24.00 & 78.83 \\
Litter & 76.50 & 54.17 & 59.50 & 11.33 \\
Total canopy cover (Biotic crust or Litter not & & & & \\
included) & $\mathbf{1 0 2 . 5}$ & $\mathbf{8 1 . 3}$ & $\mathbf{9 9 . 5}$ & $\mathbf{6 2 . 0}$ \\
\hline
\end{tabular}

* Introduced species.

$\mathrm{X}=$ Species observed but not counted in a plot frame.

-- = Not present on site.

\% Cover Introduced Species

$\%$ Cover Native

Change in Native Plant \% Cover from 2006 to 2007

$\begin{array}{rccc}85.5 & 75.3 & 35.8 & 21.8 \\ 17.0 & 6.0 & 63.7 & 40.2 \\ -18.3 & +0.7 & +38.5 & +15.0\end{array}$


Table C-5. Percent Frequency on the 120-N-1 and 120-N-2 Sites in 2007.

\begin{tabular}{|c|c|c|c|c|}
\hline Species & $\begin{array}{c}\text { Biosol and } \\
\text { Straw } \\
\text { Mulch } \\
\end{array}$ & $\begin{array}{c}\text { Biosol and } \\
\text { Hydromulch }\end{array}$ & $\begin{array}{l}\text { Triple-16 and } \\
\text { Straw Mulch }\end{array}$ & $\begin{array}{l}\text { Triple-16 and } \\
\text { Hydromulch }\end{array}$ \\
\hline Bromus tectorum* (cheatgrass) & 100 & 100 & 100 & 100 \\
\hline Poa sandbergii (Sandberg's bluegrass) & 87 & 100 & 80 & 47 \\
\hline Salsola kali* (Russian thistle) & 7 & 87 & 60 & 53 \\
\hline Achillea millefolium (yarrow) & 13 & 80 & 7 & -- \\
\hline Agropyron spicatum (bluebunch wheatgrass) & 87 & 67 & 47 & 13 \\
\hline Centaurea diffusa* (diffuse knapweed) & 33 & 27 & 7 & 13 \\
\hline Holosteum umbellatum* (jagged chickweed) & 7 & 27 & -- & 7 \\
\hline Chrysothamnus nauseosus (gray rabbitbrush) & $\mathrm{X}$ & 20 & -- & 7 \\
\hline Oryzopsis hymenoides (Indian ricegrass) & -- & 13 & -- & 13 \\
\hline Erigeron poliospermus (cushion fleabane) & $\mathrm{X}$ & 7 & -- & -- \\
\hline Lactuca serriola* (prickly lettuce) & $\mathrm{X}$ & 7 & -- & -- \\
\hline Sisymbrium altissimum* (tumble mustard) & $\mathrm{X}$ & 7 & 7 & 40 \\
\hline Tragopogon dubius* (yellow salsify) & -- & 7 & -- & -- \\
\hline Agropyron dasytachyum (thickspike wheatgrass) & 7 & -- & -- & -- \\
\hline Artemisia tridentata (sagebrush) & 7 & -- & -- & -- \\
\hline Draba verna* (spring whitlow) & -- & -- & -- & 7 \\
\hline Erysimum asperum (wallflower) & -- & -- & -- & -- \\
\hline Poa bulbosa* (bulbous bluegrass) & 13 & -- & -- & 7 \\
\hline Penstemon acuminatus (sand beardtongue) & -- & $\mathrm{X}$ & -- & -- \\
\hline Chaenactis douglasii (hoary falseyarrow) & -- & $\mathrm{X}$ & -- & -- \\
\hline Erysimum asperum (rough wallflower) & $\mathrm{X}$ & -- & & -- \\
\hline Hordeum leporinum* (hare barley) & $\mathrm{X}$ & -- & -- & -- \\
\hline Biotic crust & 53 & 60 & -- & -- \\
\hline Bare soil & 80 & 100 & 100 & 100 \\
\hline Litter & 100 & 100 & 100 & 100 \\
\hline
\end{tabular}

* Introduced species.

$\mathrm{X}=$ present but not counted in a plot frame.

$--=$ Not present on site. 
Table C-6. Percent Canopy Cover at the Hanford Generating Plant in 2007.

\begin{tabular}{|c|c|c|}
\hline Species & Topsoil & Cobble \\
\hline Poa sandbergii (Sandberg's bluegrass) & 21.1 & 26 \\
\hline Native Grasses ${ }^{b}$ & 2.6 & 9 \\
\hline Bromus tectorum* (cheatgrass) & 73.5 & 15 \\
\hline Sisymbrium altissimum* (tumble mustard) & 3.1 & 3 \\
\hline Salsola kali* (Russian thistle) & 1.1 & 27 \\
\hline Erodium cicutarium* (storksbill) & 0.3 & 0 \\
\hline Lactuca serriola* (prickly lettuce) & 0.3 & 1 \\
\hline Chrysothamnus nauseosus (gray rabbitbrush) & $\mathrm{X}$ & 0 \\
\hline Draba verna* (spring whitlow) & 0.3 & 1 \\
\hline Holosteum umbellatum* (jagged chickweed) & 22.1 & 1 \\
\hline Vulpia myuros* (rattail fescue) & 0.1 & 1 \\
\hline Artemisia tridentata (sagebrush) & 0.3 & 0 \\
\hline Centaurea diffusa* (diffuse knapweed) & $\mathrm{X}$ & 0 \\
\hline Achillea millefolium (yarrow) & -- & 0 \\
\hline Chorispora tenella* (blue mustard) & 5.4 & 0 \\
\hline Amsinckia lycopsoides (tarweed fiddleneck) & 0.3 & 0 \\
\hline Descurainia pinnata (western tansymustard) & -- & 0 \\
\hline Ranunculus testiculatus* (bur buttercup) & 1.3 & $\mathrm{X}$ \\
\hline Poa bulbosa * (Bulbous bluegrass) & $\mathrm{X}$ & $\mathrm{X}$ \\
\hline Hordeum leporinum * (hare barley) & $\mathrm{X}$ & -- \\
\hline Machaeranthera canescens (hoary aster) & -- & $\mathrm{X}$ \\
\hline Sphaeralcea munroana (Munro's globemallow) & -- & $\mathrm{X}$ \\
\hline Bare Soil & 3.6 & 38 \\
\hline Litter & 85.9 & 56 \\
\hline Total canopy cover (Biotic crust or Litter not included) & 131.6 & 85 \\
\hline
\end{tabular}

*Introduced species.

${ }^{b}$ Includes Sandberg's bluegrass, bluebunch wheatgrass, thickspike wheatgrass, Indian ricegrass, needle-and-thread grass, and prairie junegrass seedlings.

$\mathrm{X}=$ Species present on the site but not counted in a plot frame

$--=$ Not observed on the site.

Total Introduced \% Cover 2007 
Table C-7. Frequency of Occurrence at the Hanford Generating Plant in 2007.

\begin{tabular}{|c|c|c|}
\hline Species & Topsoil & Cobble \\
\hline Poa sandbergii (Sandberg's bluegrass) & 65 & 92 \\
\hline Native Grasses ${ }^{\text {b }}$ & 35 & 72 \\
\hline Bromus tectorum* (cheatgrass) & 100 & 96 \\
\hline Sisymbrium altissimum* (tumble mustard) & 75 & 80 \\
\hline Salsola kali* (Russian thistle) & 45 & 92 \\
\hline Erodium cicutarium* (storksbill) & 10 & 12 \\
\hline Lactuca serriola* (prickly lettuce) & 10 & 28 \\
\hline Chrysothamnus nauseosus (gray rabbitbrush) & $\mathrm{X}$ & 4 \\
\hline Draba verna* (spring whitlow) & 10 & 20 \\
\hline Holosteum umbellatum* (jagged chickweed) & 80 & 28 \\
\hline Vulpia myuros* (rattail fescue) & 5 & 28 \\
\hline Artemisia tridentata (sagebrush) & 10 & 4 \\
\hline Centaurea diffusa* (diffuse knapweed) & $\mathrm{X}$ & 12 \\
\hline Achillea millefolium (yarrow) & $\mathrm{X}$ & 8 \\
\hline Chorispora tenella* (blue mustard) & 50 & 4 \\
\hline Amsinckia lycopsoides (tarweed fiddleneck) & 10 & 4 \\
\hline Descurainia pinnata (western tansymustard) & $\mathrm{X}$ & 4 \\
\hline Ranunculus testiculatus* (bur buttercup) & 25 & $\mathrm{X}$ \\
\hline Poa bulbosa * (Bulbous bluegrass) & $\mathrm{X}$ & $\mathrm{X}$ \\
\hline Hordeum leporinum * (hare barley) & $\mathrm{X}$ & -- \\
\hline Machaeranthera canescens (hoary aster) & -- & $\mathrm{X}$ \\
\hline Sphaeralcea munroana (Munro's globemallow) & -- & $\mathrm{X}$ \\
\hline Bare Soil & 70 & 92 \\
\hline Litter & 100 & 100 \\
\hline
\end{tabular}

* Introduced species.

b'Includes Sandberg's bluegrass, bluebunch wheatgrass, thickspike wheatgrass, Indian ricegrass, needle-and-thread grass, and prairie junegrass seedlings.

$\mathrm{X}=$ Species present but not counted in a plot frame $--=$ Not present on site. 
Table C-8. Percent Canopy Cover and Frequency of Occurrence at 116-N-3 in 2007.

\begin{tabular}{lcc}
\hline \multicolumn{1}{c}{ Species } & \% Cover & \% Freq \\
\hline Agropyron spicatum (bluebunch wheatgrass) & 5.1 & 43 \\
Bromus tectorum* (cheatgrass) & 16.8 & 97 \\
Salsola kali* (Russian thistle) & 14.8 & 100 \\
Lactuca serriola* (prickly lettuce) & 1.8 & 23 \\
Sisymbrium altissimum* (tumble mustard) & 1.5 & 60 \\
Poa sandbergii (Sandberg's bluegrass) & 30.8 & 90 \\
Holosteum umbellatum* (jagged chickweed) & 0.8 & 30 \\
Draba verna* (spring whitlow) & 0.3 & 10 \\
Agoseris heterophylla (mountain-dandelion) & 0.3 & 13 \\
Erodium cicutarium*(storksbill) & 0.5 & 3 \\
Amsinckia lycopsoides (tarweed fiddleneck) & 0.2 & 7 \\
Vulpia myuros* (Rattail fescue) & 0.1 & 3 \\
Oryzopsis hymenoides (Indian ricegrass) & 0.1 & 3 \\
Sitanion hystrix (bottlebrush squirreltail) & 1.5 & 13 \\
Centaurea diffusa* (diffuse knapweed) & 0.5 & 3 \\
Koeleria cristata (prairie Junegrass) & $\mathrm{X}$ & $\mathrm{X}$ \\
Machaeranthera canescens (hoary aster) & $\mathrm{X}$ & $\mathrm{X}$ \\
Bare Soil & 53.9 & 93 \\
Litter & 35.8 & 100 \\
Total canopy cover (Litter not included) & $\mathbf{7 4 . 9}$ & \\
\hline
\end{tabular}

* Introduced species.

$\mathrm{X}=$ Species observed not counted in a plot frame.

Total Introduced \% Cover 2007

Total Native \% Cover 2007

Change in Native Plant \% Cover from 2006 to $2007 \quad+21.1$ 
Table C-9. Percent Canopy Cover and Frequency of Occurrence at 116-N-1 in 2007.

\begin{tabular}{|c|c|c|}
\hline Species & \% Cover & Freq. of Occ. \\
\hline Native Grasses ${ }^{\text {b }}$ & 31.8 & 100 \\
\hline Sisymbrium altissimum* (tumble mustard) & 17.7 & 87 \\
\hline Lactuca serriola* (prickly lettuce) & 0.8 & 30 \\
\hline Bromus tectorum* (cheatgrass) & 0.9 & 37 \\
\hline Salsola kali* (Russian thistle) & 4.4 & 93 \\
\hline Artemisia tridentata (sagebrush) & 0.8 & 30 \\
\hline Poa sandbergii (Sandberg's bluegrass) & 0.1 & 3 \\
\hline Chrysothamnus nauseosus (gray rabbitbrush) & 0.1 & 3 \\
\hline Kochia scopari* (kochia) & 0.2 & 7 \\
\hline Descurainia pinnata (western tansymustard) & $\mathrm{X}$ & $\mathrm{X}$ \\
\hline Conyza canadensis * (horseweed) & $\mathrm{X}$ & $\mathrm{X}$ \\
\hline Epilobium paniculatum (tall willowherb) & $\mathrm{X}$ & $\mathrm{X}$ \\
\hline Achillea millefolium (yarrow) & $\mathrm{X}$ & $\mathrm{X}$ \\
\hline Amsinckia lycopsoides (tarweed fiddleneck) & $\mathrm{X}$ & $\mathrm{X}$ \\
\hline Oryzopsis hymenoides (Indian ricegrass) & $\mathrm{X}$ & $\mathrm{X}$ \\
\hline Agropyron spicatum (bluebunch wheatgrass) & $\mathrm{X}$ & $\mathrm{X}$ \\
\hline Poa sandbergii (Sandberg's bluegrass) & $\mathrm{X}$ & $\mathrm{X}$ \\
\hline Bare Soil & 31.3 & 97 \\
\hline Litter & 63.7 & 100 \\
\hline Total canopy cover (Litter not included) & 56.6 & \\
\hline
\end{tabular}

* Introduced species

$\mathrm{X}=$ present but not counted in plot frames

bIncludes Sandberg's bluegrass, bluebunch wheatgrass, thickspike wheatgrass, Indian ricegrass, needle-and-thread grass, and prairie junegrass seedlings.

Total Introduced \% Cover $\quad 23.92$

Total Native \% Cover 32.67 
Table C-10. Percent Canopy Cover and Frequency of Occurrence at 100-F Area Sites in 2007.

\begin{tabular}{|c|c|c|}
\hline Species & \% Cover & $\%$ Freq \\
\hline Agropyron spicatum (bluebunch wheatgrass) & 11.6 & 69 \\
\hline Bromus tectorum* (cheatgrass) & 45.6 & 97 \\
\hline Salsola kali* (Russian thistle) & 4.4 & 94 \\
\hline Sisymbrium altissimum* (tumble mustard) & 0.3 & 11 \\
\hline Artemisia tridentata (sagebrush) & 0.1 & 3 \\
\hline Poa sandbergii (Sandberg's bluegrass) & 18.7 & 94 \\
\hline Sitanion hystrix (bottlebrush squirreltail) & 0.1 & 3 \\
\hline Achillea millefolium (yarrow) & 0.1 & 6 \\
\hline Holosteum umbellatum* (jagged chickweed) & 5.4 & 26 \\
\hline Draba verna* (spring whitlow) & 0.3 & 11 \\
\hline Poa bulbosa* (bulbous bluegrass) & 0.4 & 14 \\
\hline Sporobolus cryptandrus (sanddrop seed) & 0.1 & 3 \\
\hline Erodium cicutarium* (storksbill) & 0.3 & 11 \\
\hline Vicia cracca* (bird vetch) & 1.1 & 3 \\
\hline Festuca octoflora (slender sixweeks) & 0.1 & 3 \\
\hline Oryzopsis hymenoides (Indian ricegrass) & 0.4 & 3 \\
\hline Astragalus sclerocarpus (stalk-pod milkvetch) & 0.4 & 3 \\
\hline Lepidium perfoliatum (clasping pepperweed) & 0.1 & 3 \\
\hline Astragalus succumbens (crouching milkvetch) & $\mathrm{X}$ & $\mathrm{X}$ \\
\hline Phacelia linearis (threadleaf scorpionweed) & $\mathrm{X}$ & $\mathrm{X}$ \\
\hline Koeleria cristata (prairie junegrass) & $\mathrm{X}$ & $\mathrm{X}$ \\
\hline Centaurea diffusa * (diffuse knapweed) & $\mathrm{X}$ & $\mathrm{X}$ \\
\hline Agoseris heterophylla (mountain dandelion) & $\mathrm{X}$ & $\mathrm{X}$ \\
\hline Machaeranthera canescens (hoary aster) & $\mathrm{X}$ & $\mathrm{X}$ \\
\hline Chrysothamnus nauseosus (gray rabbitbrush) & $\mathrm{X}$ & $\mathrm{X}$ \\
\hline Tragopogon dubius * (yellow salsify) & $\mathrm{X}$ & $\mathrm{X}$ \\
\hline Astragalus caricinus (buckwheat milkvetch) & $\mathrm{X}$ & $\mathrm{X}$ \\
\hline Chrysothamnus viscidiflorus (green rabbitbrush) & $\mathrm{X}$ & $\mathrm{X}$ \\
\hline Bare Soil & 28.3 & 80 \\
\hline Litter & 69.0 & 100 \\
\hline Total canopy cover (Litter not included) & 89.4 & \\
\hline
\end{tabular}

* Introduced species.

$\mathrm{X}=$ Species present on the site but not counted in a plot frame.

$--=$ Not present on site.

Total Introduced \% Cover 2007

57.71

Total Native \% Cover 2007

31.71

Change in Native Plant \% Cover from 2006 to 2007

$+15.4$ 
Table C-11. Percent Canopy Cover and Frequency on the 100-B-1 and 128-C-1 Sites in 2007.

\begin{tabular}{|c|c|c|c|c|}
\hline Species & $\begin{array}{c}\text { \% Cover on } \\
100-B-1\end{array}$ & $\begin{array}{c}\text { \% Cover on } \\
\text { 128-C-1 }\end{array}$ & $\begin{array}{c}\text { \% Frequency } \\
\text { on } \\
\text { 100-B-1 } \\
\end{array}$ & $\begin{array}{c}\% \text { Frequency } \\
\text { on } \\
100-\mathrm{C}-1 \\
\end{array}$ \\
\hline Sisymbrium altissimum* (tumble mustard) & 6.1 & 1.2 & 84 & 47 \\
\hline Salsola kali* (Russian thistle) & 17.8 & 19.2 & 100 & 100 \\
\hline Poa sandbergii (Sandberg's bluegrass) & 41.6 & 8.8 & 100 & 67 \\
\hline Agropyron spp.(Wheatgrasses) & 2.7 & 1.5 & 68 & 60 \\
\hline Bromus tectorum* (cheatgrass) & 18.5 & 17.7 & 84 & 100 \\
\hline Poa bulbosa (Bulbous bluegrass) & 0.1 & -- & 4 & -- \\
\hline Hordeum leporinum* (hare barley) & 0.2 & -- & 8 & -- \\
\hline Amsinckia lycopsoides (tarweed fiddleneck) & 0.7 & -- & 8 & -- \\
\hline Agoseris heterophylla (mountain dandelion) & 0.1 & 0.2 & 4 & 7 \\
\hline Vulpia myuros* (rattail fescue) & 0.1 & -- & 4 & -- \\
\hline Artemisia tridentata (sagebrush) & 0.1 & 1.0 & 4 & 7 \\
\hline Grayia spinosa (hopsage) & $\mathrm{X}$ & -- & $\mathrm{X}$ & -- \\
\hline Descurainia pinnata (western tansymustard) & $\mathrm{X}$ & -- & $\mathrm{X}$ & -- \\
\hline Hordeum leporinum * (hare barley) & $\mathrm{X}$ & -- & $\mathrm{X}$ & -- \\
\hline Kochia scoparia * (kochia) & $\mathrm{X}$ & -- & $\mathrm{X}$ & -- \\
\hline Amsinckia lycopsoides (fiddleneck) & $\mathrm{X}$ & -- & $\mathrm{X}$ & -- \\
\hline Lactuca serriola* (prickly lettuce) & -- & 0.7 & -- & 27 \\
\hline Sitanion hystrix (bottlebrush squirreltail) & -- & 12.2 & -- & 73 \\
\hline Draba verna (spring whitlowgrass) & -- & 0.5 & -- & 20 \\
\hline Oryzopsis hymenoides (Indian ricegrass) & -- & 1.3 & -- & 20 \\
\hline Bare Soil & 30.5 & 34.2 & 96 & 100 \\
\hline Litter & 57.2 & 55.2 & 100 & 100 \\
\hline Total Canopy Cover (litter not included) & 88.0 & 64.2 & & \\
\hline \multicolumn{5}{|l|}{$\begin{array}{l}\text { * Introduced species. } \\
\text { X = Observed on the site but not counted in a } \\
\text { plot frame. } \\
\text {-- = Not present on site. }\end{array}$} \\
\hline Total Introduced \% Cover 2007 & 42.6 & 39.2 & & \\
\hline $\begin{array}{l}\text { Total Native \% Cover } 2007 \\
\text { Difference in \% Cover of Native Plants from }\end{array}$ & 45.4 & 25.0 & & \\
\hline 2006 to 2007 & +31.2 & +20.8 & & \\
\hline
\end{tabular}


WCH-428

Rev. 0

\section{APPENDIX D}

\section{REVEGETATION MONITORING RESULTS}


WCH-428

Rev. 0

2010 River Corridor Closure Contractor Revegetation and Mitigation Monitoring Report 


\section{Table D-1. Percent Canopy Cover and Frequency of Occurrence at the 300-FF-1 Process Ponds and Burial Grounds in 2006.}

\begin{tabular}{|c|c|c|}
\hline Species & \% Cover & \% Frequency \\
\hline Agropyron dasytachyum (thickspike wheatgrass) & $\mathrm{X}$ & $\mathrm{X}$ \\
\hline Agropyron spicatum (bluebunch Wheatgrass) & 7.6 & 68.6 \\
\hline Agropyron cristatum $^{\text {a }}$ (crested Wheatgrass) & 4.9 & 42.9 \\
\hline Stipa comata (needle-and-thread grass) & $\mathrm{X}$ & $\mathrm{X}$ \\
\hline Oryzopsis hymenoides (Indian ricegrass) & 0.2 & 8.6 \\
\hline Vulpia myuros ${ }^{\text {a }}$ (rattail) & 3.0 & 51.4 \\
\hline Melilotus officinalis ${ }^{\text {a }}$ (sweetclover) & 0.0 & 0.0 \\
\hline Eriogonum niveum (snow buckwheat) & $\mathrm{X}$ & $\mathrm{X}$ \\
\hline Poa sandbergii (Sandberg's bluegrass) & 9.4 & 77.1 \\
\hline Centaurea diffusa $^{\text {a }}$ (diffuse knapweed) & 0.1 & 2.9 \\
\hline Sisymbrium altissimum ${ }^{a}$ (tumble mustard) & 3.0 & 77.1 \\
\hline Bromus tectorum ${ }^{\text {a }}$ (cheatgrass) & 16.9 & 94.3 \\
\hline Lactuca serriola $^{\text {a }}$ (prickly lettuce) & 0.3 & 11.4 \\
\hline Amsinckia lycopsoides (tarweed fiddleneck) & 0.6 & 25.7 \\
\hline Phacelia hastata (whiteleaf scorpionweed) & 0.1 & 2.9 \\
\hline Ambrosia acanthicarpa (bur ragweed) & 0.1 & 5.7 \\
\hline Erodium cicutarium $^{\text {a }}$ (storksbill) & 1.1 & 42.9 \\
\hline Senecio vulgaris (common groundsel) & 0.1 & 2.9 \\
\hline${\text { Salsola } \text { kali }^{\text {a }} \text { (Russian thistle) }}$ & 2.1 & 68.6 \\
\hline Lepidium perfoliatum (clasping pepperweed) & $\mathrm{X}$ & $\mathrm{X}$ \\
\hline Oenothera pallida (pale evening primrose) & $\mathrm{X}$ & $\mathrm{X}$ \\
\hline Psoralea lanceolata (dune scurfpea) & $\mathrm{X}$ & $\mathrm{X}$ \\
\hline Cryptantha circumscissa (matted cryptantha) & $\mathrm{X}$ & $\mathrm{X}$ \\
\hline Chrysothamnus nauseosus (gray rabbitbrush) & $\mathrm{X}$ & $\mathrm{X}$ \\
\hline Poa bulbosa ${ }^{a}$ (bulbous bluegrass) & 0.2 & 8.6 \\
\hline Hymenopappus filifolius (Columbia cutleaf) & $\mathrm{X}$ & $\mathrm{X}$ \\
\hline Petalostemon ornatum (prairie clover) & $\mathrm{X}$ & $\mathrm{X}$ \\
\hline Sphaeralcea munroana (globemallow) & $\mathrm{X}$ & $\mathrm{X}$ \\
\hline Achillea millefolium (yarrow) & $\mathrm{X}$ & $\mathrm{X}$ \\
\hline Epilobium paniculatum (tall willowherb) & 0.2 & 8.6 \\
\hline Descurainia pinnata (western tansymustard) & 0.2 & 8.6 \\
\hline Artemisia tridentata (sagebrush) & $\mathrm{X}$ & $\mathrm{X}$ \\
\hline Draba verna (spring whitlowgrass) & 0.1 & 2.9 \\
\hline Tragopogon dubius (yellow salsify) & 0.1 & 2.9 \\
\hline Gilia leptomeria (Great Basin gilia) & $\mathrm{X}$ & $\mathrm{X}$ \\
\hline Verbascum thapsus $^{\text {a }}$ (common mullein) & $\mathrm{X}$ & $\mathrm{X}$ \\
\hline Biotic crust & 0.8 & 31.4 \\
\hline Bare Soil & 33.9 & 94.3 \\
\hline \multirow[b]{2}{*}{ Total cover (does not include biotic crust or litter) } & 51.2 & 100.0 \\
\hline & 50.2 & \\
\hline
\end{tabular}

\footnotetext{
${ }^{\mathrm{a}}$ Introduced species.

$\mathrm{X}=$ Species present on the site but not counted in a plot frame.
} 
Table D-2. Percent Canopy Cover on the 120-N-1 and 120-N-2 Sites in 2006.

\begin{tabular}{|c|c|c|c|c|}
\hline Species & $\begin{array}{l}\text { Triple } 16 \\
\text { and Straw } \\
\text { Mulch }\end{array}$ & $\begin{array}{l}\text { Triple } 16 \text { and } \\
\text { Hydromulch }\end{array}$ & $\begin{array}{l}\text { Biosol and } \\
\text { Straw } \\
\text { Mulch }\end{array}$ & $\begin{array}{l}\text { Biosol and } \\
\text { Hydromulch }\end{array}$ \\
\hline Agropyron dasytachyum (thickspike wheatgrass) & $\mathrm{X}$ & 0.3 & $\mathrm{X}$ & -- \\
\hline Agropyron spicatum (bluebunch wheatgrass) & 15.8 & 2.0 & 8.8 & $\mathrm{X}$ \\
\hline Poa sandbergii (Sandberg's bluegrass) & 20.7 & 17.7 & 24.7 & 3.1 \\
\hline Stipa comata (needle-and-thread grass) & $\mathrm{X}$ & $\mathrm{X}$ & $\mathrm{X}$ & -- \\
\hline Bromus tectorum ${ }^{\text {a }}$ (cheatgrass) & 23.2 & 2.5 & 60.8 & 62.1 \\
\hline 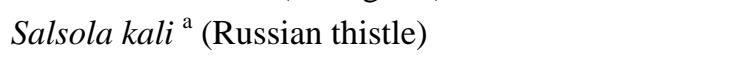 & 1.2 & 1.7 & 0.5 & 1.0 \\
\hline Achillea millefolium (yarrow) & 2.2 & 3.7 & 0.2 & $\mathrm{X}$ \\
\hline Vulpia myuros $^{\mathrm{a}}$ (rattail fescue) & 0.2 & -- & 1.3 & -- \\
\hline Artemisia tridentata (big sagebrush) & 0.5 & $\mathrm{X}$ & $\mathrm{X}$ & $\mathrm{X}$ \\
\hline Centaurea diffusa ${ }^{\text {a }}$ (diffuse knapweed) & 0.7 & 0.7 & 0.2 & 0.2 \\
\hline Chrysothamnus nauseosus (gray rabbitbrush) & 0.2 & 0.3 & 0.2 & 0.2 \\
\hline Eriogonum niveum (snow buckwheat) & -- & $\mathrm{X}$ & -- & -- \\
\hline Erodium cicutarium ${ }^{\mathrm{a}}$ (storksbill) & $\mathrm{X}$ & -- & -- & 0.2 \\
\hline Lactuca serriola $^{\text {a }}$ (prickly lettuce) & 0.3 & $\mathrm{X}$ & 0.2 & -- \\
\hline Festuca octoflora (slender sixweeks) & 0.2 & -- & 1.0 & 0.6 \\
\hline Sisymbrium altissimum ${ }^{\mathrm{a}}$ (tumblemustard) & 0.5 & 0.7 & 1.2 & 1.9 \\
\hline Tragopogon dubius ${ }^{\text {a }}$ (yellow salsify) & $\mathrm{X}$ & -- & -- & -- \\
\hline Machaeranthera canescens (hoary aster) & $\mathrm{X}$ & $\mathrm{X}$ & -- & $\mathrm{X}$ \\
\hline Chaenactis douglasii (hoary falseyarrow) & $\mathrm{X}$ & $\mathrm{X}$ & -- & $\mathrm{X}$ \\
\hline Microsteris gracilis (pink microsteris) & -- & -- & 0.2 & -- \\
\hline Penstemon acuminatus (sand beardtongue) & -- & $\mathrm{X}$ & -- & -- \\
\hline Erigeron poliospermus (cushion fleabane) & $\mathrm{X}$ & $\mathrm{X}$ & -- & $\mathrm{X}$ \\
\hline Oryzopsis hymenoides (Indian ricegrass) & -- & 0.3 & $\mathrm{X}$ & 0.4 \\
\hline Draba verna (spring whitlowgrass) & 0.2 & 0.2 & 0.2 & 0.6 \\
\hline Holosteum umbellatum (jagged chickweed) & $\mathrm{X}$ & 0.7 & -- & 0.4 \\
\hline Erysimum asperum (rough wallflower) & -- & $\mathrm{X}$ & $\mathrm{X}$ & $\mathrm{X}$ \\
\hline Erigeron pumilis (shaggy fleabane) & $\mathrm{X}$ & -- & -- & -- \\
\hline Erigeron filifolius (threadleaf fleabane) & $\mathrm{X}$ & -- & -- & -- \\
\hline Poa bulbosa ${ }^{\mathrm{a}}$ (bulbous bluegrass) & 0.3 & $\mathrm{X}$ & $\mathrm{X}$ & $\mathrm{X}$ \\
\hline Ranunculus testiculatus ${ }^{\text {a }}$ (bur buttercup) & 0.2 & -- & 0.2 & -- \\
\hline Biotic crust & 0.7 & 0.2 & -- & -- \\
\hline Bare soil & 27.8 & 82.0 & 20.0 & 47.9 \\
\hline Litter & 58.5 & 5.8 & 77.7 & 44.0 \\
\hline Total Cover (does not include biotic crust or litter) & 66.2 & 30.7 & 99.5 & 70.8 \\
\hline
\end{tabular}


Table D-3. Percent Frequency of Occurrence on the 120-N-1 and 120-N-2 Sites in 2006.

\begin{tabular}{|c|c|c|c|c|}
\hline Species & $\begin{array}{l}\text { Triple } 16 \\
\text { and Straw } \\
\text { Mulch }\end{array}$ & $\begin{array}{c}\text { Triple } 16 \\
\text { and } \\
\text { Hydromulch }\end{array}$ & $\begin{array}{c}\text { Biosol and } \\
\text { Straw } \\
\text { Mulch } \\
\end{array}$ & $\begin{array}{l}\text { Biosol and } \\
\text { Hydromulch }\end{array}$ \\
\hline Agropyron dasytachyum (thickspike wheatgrass) & $\mathrm{X}$ & 13 & X & -- \\
\hline Agropyron spicatum (bluebunch wheatgrass) & 93 & 47 & 66.7 & $\mathrm{X}$ \\
\hline Poa sandbergii (Sandberg's bluegrass) & 100 & 100 & 100 & 83.3 \\
\hline Stipa comata (needle-and-thread grass) & $\mathrm{X}$ & $\mathrm{X}$ & $\mathrm{X}$ & -- \\
\hline Bromus tectorum $^{\text {a }}$ (cheatgrass) & 100 & 100 & 100 & 100 \\
\hline Salsola kali $^{\text {a }(\text { Russian thistle) }}$ & 47 & 67 & 20 & 41.7 \\
\hline Achillea millefolium (yarrow) & 53 & 80 & 6.7 & $\mathrm{X}$ \\
\hline Vulpia myuros ${ }^{a}$ (rattail fescue) & 7 & -- & 20 & -- \\
\hline Artemisia tridentata (big sagebrush) & 20 & $\mathrm{X}$ & $\mathrm{X}$ & $\mathrm{X}$ \\
\hline Centaurea diffusa ${ }^{\text {a }}$ (diffuse knapweed) & 27 & 27 & 6.7 & 8.3 \\
\hline Chrysothamnus nauseosus (gray rabbitbrush) & 7 & 13 & 6.7 & 8.3 \\
\hline Eriogonum niveum (snow buckwheat) & -- & $\mathrm{X}$ & -- & -- \\
\hline Erodium cicutarium ${ }^{\text {a }}$ (storksbill) & $\mathrm{X}$ & -- & -- & 8.3 \\
\hline Lactuca serriola $^{\text {a }}$ (prickly lettuce) & 13 & $\mathrm{X}$ & 6.7 & -- \\
\hline Festuca octoflora (slender sixweeks) & 7 & -- & 40 & 25 \\
\hline Sisymbrium altissimum ${ }^{\mathrm{a}}$ (tumblemustard) & 20 & 27 & 46.7 & 75 \\
\hline Tragopogon dubius ${ }^{\text {a }}$ (yellow salsify) & $\mathrm{X}$ & -- & -- & -- \\
\hline Machaeranthera canescens (hoary aster) & $\mathrm{X}$ & $\mathrm{X}$ & -- & $\mathrm{X}$ \\
\hline Chaenactis douglasii (hoary falseyarrow) & $\mathrm{X}$ & $\mathrm{X}$ & -- & $\mathrm{X}$ \\
\hline Microsteris gracilis (pink microsteris) & -- & -- & 6.7 & -- \\
\hline Penstemon acuminatus (sand beardtongue) & -- & $\mathrm{X}$ & -- & -- \\
\hline Erigeron poliospermus (cushion fleabane) & $\mathrm{X}$ & $\mathrm{X}$ & -- & $\mathrm{X}$ \\
\hline Oryzopsis hymenoides (Indian ricegrass) & -- & 13 & $\mathrm{X}$ & 16.7 \\
\hline Draba verna (spring whitlowgrass) & 7 & 7 & 6.7 & 25 \\
\hline Holosteum umbellatum (jagged chickweed) & $\mathrm{X}$ & 27 & -- & 16.7 \\
\hline Erysimum asperum (rough wallflower) & -- & $\mathrm{X}$ & $\mathrm{X}$ & $\mathrm{X}$ \\
\hline Erigeron pumilis (shaggy fleabane) & $\mathrm{X}$ & -- & -- & -- \\
\hline Erigeron filifolius (threadleaf fleabane) & $\mathrm{X}$ & -- & -- & -- \\
\hline Poa bulbosa ${ }^{\text {a }}$ (bulbous bluegrass) & 13 & $\mathrm{X}$ & $\mathrm{X}$ & $\mathrm{X}$ \\
\hline Ranunculus testiculatus ${ }^{\text {a }}$ (bur buttercup) & -- & -- & 6.7 & -- \\
\hline Biotic crust & 27 & 7 & -- & -- \\
\hline Bare soil & 100 & 100 & 100 & 100 \\
\hline Litter & 100 & 100 & 100 & 100 \\
\hline
\end{tabular}

${ }^{\mathrm{a}}$ Introduced species.

$\mathrm{X}=$ Species observed on the treatment but not counted in a plot frame.

-- = Species not observed on the treatment. 
Table D-4. Percent Canopy Cover at the Hanford Generating Plant in 2006.

\begin{tabular}{|c|c|c|}
\hline Species & Topsoil & Cobble \\
\hline Native Grasses ${ }^{\text {b }}$ & 20.4 & 34.8 \\
\hline Bromus tectorum ${ }^{\text {a }}$ (cheatgrass) & 15.0 & 2.1 \\
\hline Salsola kali $^{\text {a }(\text { Russian thistle) }}$ & 26.1 & 19.9 \\
\hline Artemisia tridentata (sagebrush) & 0.3 & 0.1 \\
\hline Chorispora tenella $^{\text {a }}$ (blue mustard) & 1.8 & 1.5 \\
\hline Amsinckia lycopsoides (fiddleneck) & 0.1 & 0.1 \\
\hline Draba verna (spring whitlowgrass) & $\mathrm{X}$ & 0.1 \\
\hline Ranunculus testiculatus ${ }^{\text {a }}$ (bur buttercup) & 0.3 & -- \\
\hline Lactuca serriola $^{\mathrm{a}}$ (prickly lettuce) & $\mathrm{X}$ & 0.4 \\
\hline Melilotus alba ${ }^{\text {a }}$ (sweetclover) & 0.1 & $\mathrm{X}$ \\
\hline Festuca octoflora (slender sixweeks) & -- & 0.3 \\
\hline Sisymbrium altissimum ${ }^{\text {a }}$ (tumble mustard) & 1.0 & 9.1 \\
\hline Poa bulbosa ${ }^{\text {a }}$ (Bulbous bluegrass) & -- & $\mathrm{X}$ \\
\hline Holosteum umbellatum (jagged chickweed) & 0.4 & 0.3 \\
\hline Centaurea diffusa ${ }^{\text {a }}$ (diffuse knapweed) & 0.5 & 0.4 \\
\hline Sphaeralcea munroana (Munro's globemallow) & $\mathrm{X}$ & $\mathrm{X}$ \\
\hline Erodium cicutarium ${ }^{a}$ (storksbill) & 0.1 & $\mathrm{X}$ \\
\hline Kochia scoparia ${ }^{\text {a }}$ (kochia) & 0.1 & -- \\
\hline Tragopogon dubius (yellow salsify) & -- & 0.1 \\
\hline Chrysothamnus nauseosus (gray rabbitbrush) & -- & $\mathrm{X}$ \\
\hline Machaeranthera canescens (hoary aster) & -- & $\mathrm{X}$ \\
\hline Achillea millefolium (yarrow) & -- & $\mathrm{X}$ \\
\hline Epilobium paniculatum (tall willowherb) & -- & $\mathrm{X}$ \\
\hline Bare Soil & 34.4 & 31.7 \\
\hline Litter & 30.4 & 64.6 \\
\hline Total Cover (does not include litter) & 66.1 & 69.2 \\
\hline
\end{tabular}

\footnotetext{
${ }^{\mathrm{a}}$ Introduced species.

${ }^{\mathrm{b}}$ Includes Sandberg's bluegrass, bluebunch wheatgrass, Indian ricegrass, needle-and-thread grass, and prairie junegrass seedlings.

$\mathrm{X}=$ Species present on the site but not counted in a plot frame.

-- = Not observed on the site.
} 
Table D-5. Frequency of Occurrence at the Hanford Generating Plant in 2006.

\begin{tabular}{|c|c|c|}
\hline Species & Topsoil & Cobble \\
\hline Native Grasses ${ }^{\text {b }}$ & 100 & 100 \\
\hline Bromus tectorum ${ }^{a}$ (cheatgrass) & 90 & 64 \\
\hline Salsola kali $^{\text {a }}$ (Russian thistle) & 100 & 96 \\
\hline Artemisia tridentata (sagebrush) & 15 & 4 \\
\hline Chorispora tenella ${ }^{\text {a }}$ (blue mustard) & 20 & 4 \\
\hline Amsinckia lycopsoides (fiddleneck) & 5 & 4 \\
\hline Draba verna (spring whitlowgrass) & $\mathrm{X}$ & 4 \\
\hline Ranunculus testiculatus ${ }^{\text {a }}$ (bur buttercup) & 10 & -- \\
\hline Lactuca serriola $^{\text {a }}$ (prickly lettuce) & $\mathrm{X}$ & 16 \\
\hline Melilotus alba a (sweetclover) & 5 & $\mathrm{X}$ \\
\hline Festuca octoflora (slender sixweeks) & -- & 12 \\
\hline Sisymbrium altissimum a (tumble mustard) & 60 & 92 \\
\hline Poa bulbosa ${ }^{\text {a }}$ (Bulbous bluegrass) & -- & $\mathrm{X}$ \\
\hline Holosteum umbellatum (jagged chickweed) & 40 & 12 \\
\hline Centaurea diffusa ${ }^{\text {a }}$ (diffuse knapweed) & 20 & 16 \\
\hline Sphaeralcea munroana (Munro's globemallow) & $\mathrm{X}$ & $\mathrm{X}$ \\
\hline Erodium cicutarium ${ }^{\text {a }}$ (storksbill) & 5 & $\mathrm{X}$ \\
\hline Kochia scoparia ${ }^{\text {a }}$ (kochia) & 5 & -- \\
\hline Tragopogon dubius (yellow salsify) & -- & 4 \\
\hline Chrysothamnus nauseosus (gray rabbitbrush) & -- & $\mathrm{X}$ \\
\hline Machaeranthera canescens (hoary aster) & -- & $\mathrm{X}$ \\
\hline Achillea millefolium (yarrow) & -- & $\mathrm{X}$ \\
\hline Epilobium paniculatum (tall willowherb) & -- & $\mathrm{X}$ \\
\hline Bare Soil & 100 & 88 \\
\hline Litter & 100 & 100 \\
\hline
\end{tabular}

${ }^{\mathrm{a}}$ Introduced species.

${ }^{\mathrm{b}}$ Includes Sandberg's bluegrass, bluebunch wheatgrass, Indian ricegrass, needle-andthread grass, and Prairie junegrass seedlings.

$\mathrm{X}=$ Species present on the site but not counted in a plotframe.

-- = Not observed on the site

Table D-6. Percent Canopy Cover and Frequency of Occurrence at the 116-N-3 Site in 2006. 


\begin{tabular}{|c|c|c|}
\hline Species & \% Cover & \% Frequency \\
\hline Agropyron spicatum (bluebunch wheatgrass) & 7.8 & 86.7 \\
\hline Salsola kali $^{\text {a }(\text { Russian thistle) }}$ & 14.5 & 86.7 \\
\hline Sitanion hystrix (bottlebrush squirreltail) & 1.9 & 43.3 \\
\hline Koeleria cristata (prairie junegrass) & 0.3 & 10.0 \\
\hline Bromus tectorum ${ }^{\text {a }}$ (cheatgrass) & 3.8 & 66.7 \\
\hline Stipa comata (needle-and-thread grass) & 0.5 & 20.0 \\
\hline Poa sandbergii (Sandberg's bluegrass) & 5.8 & 73.3 \\
\hline Sisymbrium altissimum ${ }^{\mathrm{a}}$ (tumblemustard) & 0.2 & 6.7 \\
\hline Artemisia tridentata (big sagebrush) & $\mathrm{X}$ & $\mathrm{X}$ \\
\hline Oryzopsis hymenoides (Indian ricegrass) & 0.3 & 13.3 \\
\hline Holosteum umbellatum (jagged chickweed) & 0.3 & 13.3 \\
\hline Agropyron dasytachyum (thickspike wheatgrass) & $\mathrm{X}$ & $\mathrm{X}$ \\
\hline Achillea millefolium (yarrow) & $\mathrm{X}$ & $\mathrm{X}$ \\
\hline Draba verna (spring whitlowgrass) & 0.1 & 3.3 \\
\hline Lactuca serriola $^{\text {a }}$ (prickly lettuce) & 0.6 & 23.3 \\
\hline Amsinckia lycopsoides (tarweed fiddleneck) & $\mathrm{X}$ & $\mathrm{X}$ \\
\hline Machaeranthera canescens (hoary aster) & $\mathrm{X}$ & $\mathrm{X}$ \\
\hline Poa bulbosa ${ }^{\text {a }}$ (bulbous bluegrass) & $\mathrm{X}$ & $\mathrm{X}$ \\
\hline Chrysothamnus nauseosus (gray rabbitbrush) & $\mathrm{X}$ & $\mathrm{X}$ \\
\hline Grayia spinosa (hopsage) & $\mathrm{X}$ & $\mathrm{X}$ \\
\hline Vulpia myuros $^{\text {a }}$ (rattail fescue) & $\mathrm{X}$ & $\mathrm{X}$ \\
\hline Senecio vulgaris ${ }^{\text {a }}$ (common groundsel) & $\mathrm{X}$ & $\mathrm{X}$ \\
\hline Melilotus officinalis ${ }^{\text {a }}$ (sweetclover) & $\mathrm{X}$ & $\mathrm{X}$ \\
\hline Erodium cicutarium ${ }^{\text {a }}$ (storksbill) & $\mathrm{X}$ & $\mathrm{X}$ \\
\hline Centaurea diffusa ${ }^{\text {a }}$ (diffuse knapweed) & $\mathrm{X}$ & $\mathrm{X}$ \\
\hline Bare soil & 41.0 & 90.0 \\
\hline Litter & 44.4 & 100.0 \\
\hline Total Cover (does not include biotic crust or litter) & 36.0 & \\
\hline
\end{tabular}

${ }^{\mathrm{a}}$ Introduced species.

$\mathrm{X}=$ Species observed on the site but not counted in a plot frame. 
Table D-7. Percent Canopy Cover and Frequency of Occurrence at the 100-F Area Sites in 2006.

\begin{tabular}{|c|c|c|}
\hline Species & \% Cover & \% Frequency \\
\hline Agropyron spicatum (bluebunch wheatgrass) & 6.3 & 96 \\
\hline Oryzopsis hymenoides (Indian ricegrass) & 0.7 & 28 \\
\hline Stipa comata (needle-and-thread grass) & 0.1 & 4 \\
\hline Poa sandbergii (Sandberg's bluegrass) & 7 & 88 \\
\hline Sitanion hystrix (squirreltail grass) & 0.7 & 8 \\
\hline Salsola kali $^{\text {a }(\text { Russian thistle) }}$ & 1.9 & 56 \\
\hline Achillea millefolium (yarrow) & 0.3 & 12 \\
\hline Sisymbrium altissimum ${ }^{\mathrm{a}}$ (tumblemustard) & 0.5 & 20 \\
\hline Descurainia pinnata (western tansymustard) & 0.1 & 4 \\
\hline Amsinckia lycopsoides (tarweed fiddleneck) & $\mathrm{X}$ & $\mathrm{X}$ \\
\hline Artemisia tridentata (big sagebrush) & $\mathrm{X}$ & $\mathrm{X}$ \\
\hline Chrysothamnus nauseosus (gray rabbitbrush) & $\mathrm{X}$ & $\mathrm{X}$ \\
\hline Chrysothamnus viscidiflorus (green rabbitbrush) & $\mathrm{X}$ & $\mathrm{X}$ \\
\hline Erodium cicutarium ${ }^{\text {a }}$ (storksbill) & $\mathrm{X}$ & $\mathrm{X}$ \\
\hline Bromus tectorum ${ }^{\text {a }}$ (cheatgrass) & 23 & 100 \\
\hline Phacelia hastata (threadleaf scorpionweed) & $\mathrm{X}$ & $\mathrm{X}$ \\
\hline Cryptantha leucophaea (gray cryptantha) & $\mathrm{X}$ & $\mathrm{X}$ \\
\hline Lactuca serriola ${ }^{a}$ (prickly lettuce) & 0.1 & 4 \\
\hline Machaeranthera canescens (hoary aster) & $\mathrm{X}$ & $\mathrm{X}$ \\
\hline Epilobium paniculatum (tall willowherb) & $\mathrm{X}$ & $\mathrm{X}$ \\
\hline Poa bulbosa ${ }^{\text {a }}$ (bulbous bluegrass) & 0.4 & 16 \\
\hline Agropyron dasytachyum (thickspike wheatgrass) & 0.1 & 4 \\
\hline Tragopogon dubius ${ }^{\text {a }}$ (yellow salsify) & 0.2 & 8 \\
\hline Lepidium perfoliatum ${ }^{\text {a }}$ (clasping pepperweed) & $\mathrm{X}$ & $\mathrm{X}$ \\
\hline Holosteum umbellatum (jagged chickweed) & 0.8 & 32 \\
\hline Sphaeralcea munroana (globemallow) & $\mathrm{X}$ & $\mathrm{X}$ \\
\hline Centaurea diffusa ${ }^{\text {a }}$ (diffuse knapweed) & $\mathrm{X}$ & $\mathrm{X}$ \\
\hline Ambrosia acanthicarpa (bur ragweed) & $\mathrm{X}$ & $\mathrm{X}$ \\
\hline Astragalus sclerocarpus (stalked pod milkvetch) & $\mathrm{X}$ & $\mathrm{X}$ \\
\hline Astragalus succumbens (crouching milkvetch) & $\mathrm{X}$ & $\mathrm{X}$ \\
\hline 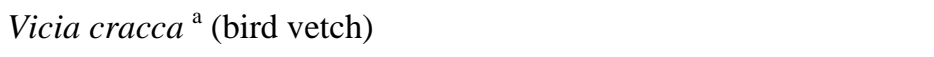 & $\mathrm{X}$ & $\mathrm{X}$ \\
\hline Festuca octoflora (slender sixweeks) & 0.2 & 8 \\
\hline Draba verna (spring whitlowgrass) & 0.1 & 4 \\
\hline Eriogonum niveum (snow buckwheat) & $\mathrm{X}$ & $\mathrm{X}$ \\
\hline Bare soil & 25.7 & 64 \\
\hline Litter & 68.1 & 100 \\
\hline Total Cover (does not include litter) & 42.5 & \\
\hline
\end{tabular}

${ }^{\mathrm{a}}$ Introduced species.

$\mathrm{X}=$ Species present on the site but not counted in a plot frame. 
Table D-8. Percent Frequency of Occurrence at the 100 B/C Sites in 2006.

\begin{tabular}{|c|c|c|}
\hline Species & 100-B-1 & 128-C-1 \\
\hline Native Grasses ${ }^{b}$ & 100 & 100 \\
\hline Bromus tectorum ${ }^{\text {a }}$ (cheatgrass) & 56 & 26.7 \\
\hline Salsola kali ${ }^{\text {a }}$ (Russian thistle) & 96 & 100 \\
\hline Artemisia tridentata (sagebrush) & 4 & $\mathrm{X}$ \\
\hline Ambrosia acanthicarpa (bur ragweed) & 4 & -- \\
\hline Amsinckia lycopsoides (fiddleneck) & 4 & $\mathrm{X}$ \\
\hline Balsamorhiza careyana (Carey's balsamroot) & $\mathrm{X}$ & -- \\
\hline Lactuca serriola $^{\text {a }}$ (prickly lettuce) & -- & $\mathrm{X}$ \\
\hline Grayia spinosa (Spiny hopsage) & $\mathrm{X}$ & -- \\
\hline Sisymbrium altissimum ${ }^{\mathrm{a}}$ (tumble mustard) & 72 & 20 \\
\hline Vulpia myuros $^{\text {a }}$ (rattail fescue) & -- & 6.7 \\
\hline Sphaeralcea munroana (globemallow) & $\mathrm{X}$ & -- \\
\hline Kochia scoparia $^{\text {a }}$ (kochia) & 4 & -- \\
\hline Bare Soil & 100 & 100 \\
\hline Litter & 100 & 100 \\
\hline
\end{tabular}

\footnotetext{
${ }^{\mathrm{a}}$ Introduced species

${ }^{\mathrm{b}}$ Includes Sandberg's bluegrass, bluebunch wheatgrass, thickspike wheatgrass, Indian ricegrass, needle-and-thread grass, and prairie junegrass seedlings.

$\mathrm{X}=$ Observed on the site but not counted in a plot frame.

-- = Not observed on the site.
} 
Table D-9. Percent Canopy Cover on the 100 B/C Sites in 2006.

\begin{tabular}{|c|c|c|}
\hline Species & 100-B-1 & $128-\mathrm{C}-1$ \\
\hline Native Grasses ${ }^{\text {b }}$ & 13.9 & 4.2 \\
\hline Bromus tectorum ${ }^{\text {a }}$ (cheatgrass) & 0.7 & 1.5 \\
\hline Salsola kali $^{\text {a }(\text { Russian thistle) }}$ & 9.6 & 3.3 \\
\hline Artemisia tridentata (sagebrush) & 0.1 & $\mathrm{X}$ \\
\hline Ambrosia acanthicarpa (bur ragweed) & 0.1 & -- \\
\hline Amsinckia lycopsoides (fiddleneck) & 0.1 & $\mathrm{X}$ \\
\hline Balsamorhiza careyana (Carey's balsamroot) & $\mathrm{X}$ & -- \\
\hline Lactuca serriola $^{\text {a }}$ (prickly lettuce) & -- & $\mathrm{X}$ \\
\hline Grayia spinosa (Spiny hopsage) & $\mathrm{X}$ & -- \\
\hline Sisymbrium altissimum ${ }^{\mathrm{a}}$ (tumble mustard) & 1.6 & 0.5 \\
\hline Vulpia myuros ${ }^{\text {a }}$ (rattail fescue) & -- & 0.2 \\
\hline Sphaeralcea munroana (globemallow) & $\mathrm{X}$ & -- \\
\hline Kochia scoparia ${ }^{\text {a }}$ (kochia) & 0.1 & -- \\
\hline Bare Soil & 38.4 & 40.5 \\
\hline Litter & 18.7 & 31.9 \\
\hline Total Cover (does not include bare soil or litter) & 26.2 & 9.7 \\
\hline
\end{tabular}

${ }^{\mathrm{a}}$ Introduced species.

${ }^{\mathrm{b}}$ Includes Sandberg's bluegrass, bluebunch wheatgrass, thickspike wheatgrass, Indian ricegrass, needle-and-thread grass, and prairie junegrass seedlings.

$\mathrm{X}=$ Observed on the site but not counted in a plot frame.

-- = Not observed on the site. 
Table D-10. Percent Canopy Cover on the Horseshoe Landfill and Soil Staging Area in 2006.

\begin{tabular}{|c|c|c|}
\hline Species & $\begin{array}{c}\text { Horseshoe } \\
\text { Landfill }\end{array}$ & $\begin{array}{c}\text { Soil Staging } \\
\text { Area }\end{array}$ \\
\hline Native Grasses ${ }^{\text {b }}$ & 25.7 & 20.2 \\
\hline Bromus tectorum ${ }^{\text {a }}$ (cheatgrass) & 2 & 2.8 \\
\hline Artemisia tridentata (sagebrush) & 0.3 & 0.5 \\
\hline Ambrosia acanthicarpa (bur ragweed) & $\mathrm{X}$ & -- \\
\hline Amsinckia lycopsoides (fiddleneck) & $\mathrm{X}$ & 0.7 \\
\hline Amaranthus albus ${ }^{\text {a }}$ (white pigweed) & $\mathrm{X}$ & 1.3 \\
\hline Hordeum leporinum ${ }^{\text {a }}$ (hare barley) & $\mathrm{X}$ & -- \\
\hline Lactuca serriola $^{\text {a }}$ (prickly lettuce) & $\mathrm{X}$ & 0.2 \\
\hline Melilotus alba ${ }^{\text {a }}$ (sweetclover) & $\mathrm{X}$ & -- \\
\hline Festuca octoflora (slender sixweeks) & $\mathrm{X}$ & -- \\
\hline Sisymbrium altissimum ${ }^{\text {a }}$ (tumble mustard) & $\mathrm{X}$ & 8 \\
\hline Descurainia pinnata (western tansymustard) & -- & 0.3 \\
\hline Lupinus leucophyllus (velvet lupine) & -- & 0.2 \\
\hline Crepis atrabarba (slender hawksbeard) & -- & $\mathrm{X}$ \\
\hline Linum perenne (wild blueflax) & -- & 0.2 \\
\hline Erodium cicutarium ${ }^{a}$ (storksbill) & -- & $\mathrm{X}$ \\
\hline Kochia scoparia ${ }^{\text {a }}$ (kochia) & -- & $\mathrm{X}$ \\
\hline Bare Soil & 52.8 & 50.2 \\
\hline Litter & 38 & 38.8 \\
\hline Total cover (does not include litter) & 28.2 & 34.3 \\
\hline
\end{tabular}

${ }^{a}$ Introduced species

${ }^{\mathrm{b}}$ Sandberg's bluegrass, Indian ricegrass, bluebunch wheatgrass, needle-and-thread grass, and squirreltail grass

$\mathrm{X}=$ Species present on the site but not counted in a plot frame.

-- Not observed the site. 
Table D-11. Frequency of Occurrence on the Horseshoe Landfill and Soil Staging Area in 2006.

\begin{tabular}{|c|c|c|}
\hline Species & $\begin{array}{c}\text { Horseshoe } \\
\text { Landfill } \\
\end{array}$ & $\begin{array}{c}\text { Soil Staging } \\
\text { Area }\end{array}$ \\
\hline Native Grasses ${ }^{\text {b }}$ & 100 & 100 \\
\hline Bromus tectorum ${ }^{\text {a }}$ (cheatgrass) & 80 & 46.7 \\
\hline Artemisia tridentata (sagebrush) & 13.3 & 20 \\
\hline Ambrosia acanthicarpa (bur ragweed) & $\mathrm{X}$ & -- \\
\hline Amsinckia lycopsoides (fiddleneck) & $\mathrm{X}$ & 26.7 \\
\hline Amaranthus albus ${ }^{\text {a }}$ (white pigweed) & $\mathrm{X}$ & 53.3 \\
\hline Hordeum leporinum ${ }^{\text {a }}$ (hare barley) & $\mathrm{X}$ & -- \\
\hline Lactuca serriola $^{\text {a }}$ (prickly lettuce) & $\mathrm{X}$ & 6.7 \\
\hline Melilotus alba a (sweetclover) & $\mathrm{X}$ & -- \\
\hline Festuca octoflora (slender sixweeks) & $\mathrm{X}$ & -- \\
\hline Sisymbrium altissimum a (tumble mustard) & $\mathrm{X}$ & 93.3 \\
\hline Descurainia pinnata (western tansymustard) & -- & 13.3 \\
\hline Lupinus leucophyllus (velvet lupine) & -- & 6.7 \\
\hline Crepis atrabarba (slender hawksbeard) & -- & $\mathrm{X}$ \\
\hline Linum perenne (wild blueflax) & -- & 6.7 \\
\hline Erodium cicutarium ${ }^{\text {a }}$ (storksbill) & -- & $\mathrm{X}$ \\
\hline Kochia scoparia ${ }^{\text {a }}$ (kochia) & -- & $\mathrm{X}$ \\
\hline Bare Soil & 100 & 100 \\
\hline Litter & 100 & 100 \\
\hline
\end{tabular}

${ }^{\mathrm{a}}$ Introduced species

${ }^{\mathrm{b}}$ Sandberg's bluegrass, Indian ricegrass, bluebunch wheatgrass, needle-and-thread grass, and squirreltail grass

$\mathrm{X}=$ Species present on the site but not counted in a plot frame.

-- Not observed the site. 
WCH-428

Rev. 0

2010 River Corridor Closure Contractor Revegetation and Mitigation Monitoring Report September 2010 
WCH-428

Rev. 0

\section{APPENDIX E \\ NAME CHANGES INCLUDED IN INTEGRATED TAXONOMIC INFORMATION SYSTEM}


WCH-428

Rev. 0

2010 River Corridor Closure Contractor Revegetation and Mitigation Monitoring Report 


\section{NAME CHANGES INCLUDED IN INTEGRATED TAXONOMIC INFORMATION SYSTEM}

Name changes included in Integrated Taxonomic Information System (ITIS 1998).

Recent name changes for species mentioned in this report. The first name is that used in Hitchcock and Cronquist (1973) and the second is the more recent version.

Agropyron cristatum = Agropyron desertorum

Agropyron dasytachyum = Elymus lanceolatus var lanceolatus

Agropyron spicatum = Pseudoroegneria spicata ssp. spicata

Chrysothamnus nauseosus = Ericameria nauseosa ssp. nauseosa var. nauseosa

Cymopterus terebinthinus = Pteryxia terebinthina var. terebinthina

Epilobium paniculatum = Epilobium brachycarpum

Erysimum asperum = Erysimum capitatum var capitatum

Festuca octoflora = Vulpia octoflora var. octoflora

Koeleria cristata = Koeleria macrantha

Microsteris gracilis = Phlox gracilis ssp. gracilis

Oryzopsis hymenoides $=$ Achnatherum hymenoides

Poa sandbergii $=$ Poa secunda

Poa scabrella $=$ Poa secunda

Psoralea lanceolata $=$ Psoralidium lanceolatum

Ranunculus testiculatus = Ceratocephala testiculata

Salsola kali $=$ Salsola tragus

Sitanion hystrix = Elymus elymoides ssp. elymoides

Stipa comata $=$ Hesperostipa comata ssp. comata 
WCH-428

Rev. 0

2010 River Corridor Closure Contractor Revegetation and Mitigation Monitoring Report September 2010 


\section{DISTRIBUTION}

U.S. Department of Energy

$\underline{\text { Richland Operations Office }}$

W. Russell

D. C. Ward (16)

\section{$\underline{\text { River Corridor Closure Contract }}$}

K. A. Gano, EAS

H4-26

A. L. Johnson, WCH (5)

C. T. Lindsey, EAS

S. N. Harrison, WCH (25)

E. M. Weiss, WCH

Records and Document Control

DOE-RL Public Reading Room

Hanford Technical Library

$\underline{\text { Pacific Northwest National Laboratories }}$

J. L. Downs

M. R. Sackschewsky

Mission Support Alliance

A. R. Johnson

S8-25

R. C. Roos

R3-12

\section{Offsite Distribution by DOE}

2

Confederated Tribes and Bands of the Yakama Indian Nation 20808 Main Street

Union Gap, WA 98903

ATTN: Russell Jim

Lee Hoppis 
Confederated Tribes of the Umatilla Indian Reservation

Old Mission Highway 30

P.O. Box 638

Pendleton, OR 97801

ATTN: Stuart Harris

Teara Farrow

1

Environmental Assessment Services

P.O. Box 265

Richland, WA 99354

ATTN: Brett Tiller

2

Mid-Columbia River National Wildlife Refuge Complex

64 Maple St.

Burbank, WA 99323-1447

ATTN: Larry Klimck

Heidi Newsome

2

Nez Perce Tribe

Main Street and Beaver Grade

P.O. Box 365

Lapwai, ID 83540

ATTN: Dan Landeen

Gabe Bohnee

1

Oregon Department of Energy

625 Marion Street NE

Salem, OR 97310

ATTN: Paul Shaffer

3

U.S. Environmental Protection Agency

309 Bradley, Suite 115, MS B1-46

Richland, WA 99352

ATTN: David R. Einan

Dennis A. Faulk

Larry E. Gadbois

1

Wanapum

Grant County PUD

P.O. Box 878

Ephrata, WA 98823

ATTN: Lela Buck 
WCH-428

Rev. 0

1

Washington Department of Ecology

300 Desmond Drive SE

Lacey, WA 98503

ATTN: Larry Goldstein 
WCH-428

Rev. 0

2010 River Corridor Closure Contractor Revegetation and Mitigation Monitoring Report 